\title{
Quaternary Movement Along the \\ La Jencia Fault, Central New Mexico
}

U.S. GEOLOGICAL SURVEY PROFESSIONAL PAPER 1440
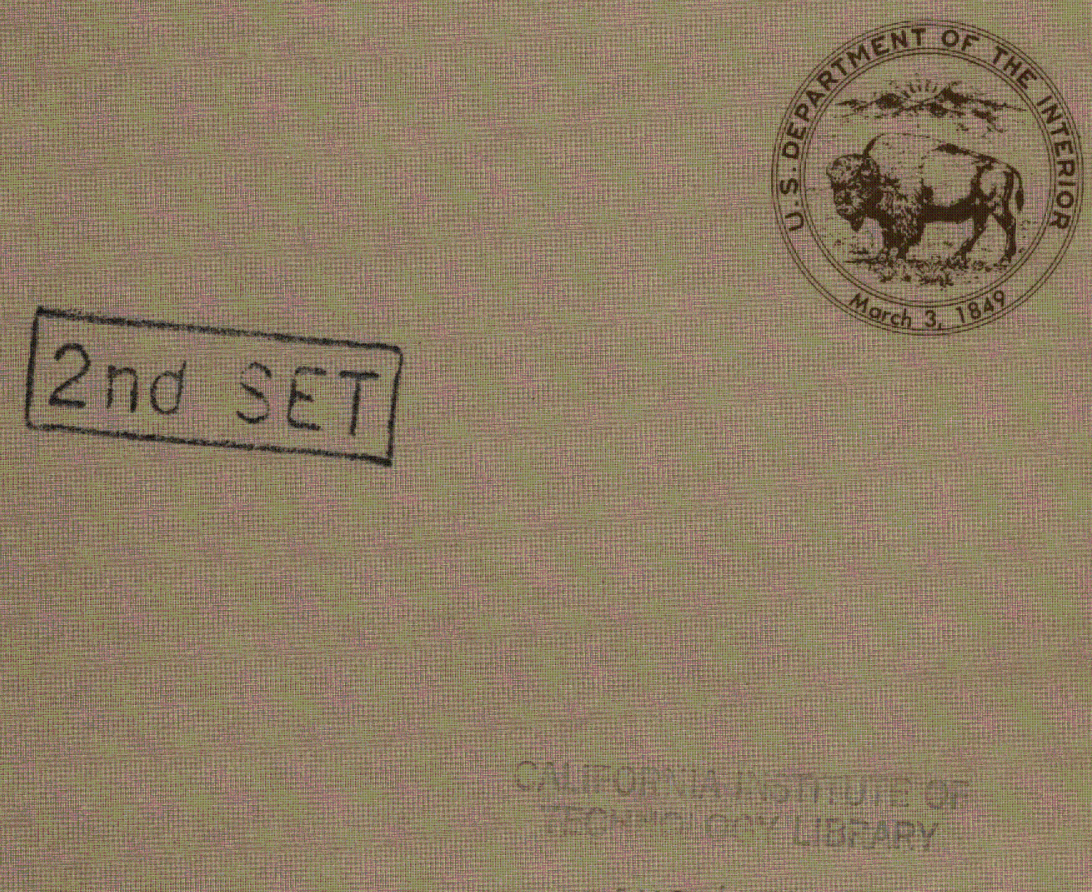

Rug 4. 1989

US. COUERNMEUT DEPOSITORY 



\section{Quaternary Movement Along the La Jencia Fault, Central New Mexico}

By MICHAEL N. MACHETTE

U.S. GEOLOGICA L S UR VEY PROFESSIONAL PAPER 1440

A detailed study of movement along a late Quaternary fault of the Rio Grande rift utilizing geologic mapping, exploratory trenches, soil development, laboratory analyses, and fault-scarp morphology

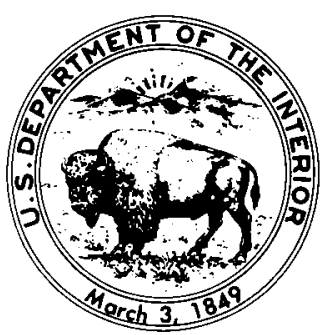




\section{DEPARTMENT OF THE INTERIOR}

DONALD PAUL HODEL, Secretary

\section{U. S. GEOLOGICAL SURVEY}

Dallas L. Peck, Director

Machette, Michael N.

Quaternary movement along the La Jencia fault, central New Mexico.

(U.S. Geological Survey professional paper; 1440)

Bibliography: p.

Supt. of Docs. no.: I 19.6:1440

1. Faults (Geology)-New Mexico. II. Series.

For sale by the Books and Open-File Reports Section, U.S. Geological Survey, Federal Center, Box 25425, Denver, CO 80225

Any use of trade, product, industry, or firm names in this publication is for descriptive purposes only and does not imply endorsement by the U.S. Government. 


\section{CONTENTS}

\begin{tabular}{|c|c|}
\hline \multicolumn{2}{|l|}{ - } \\
\hline 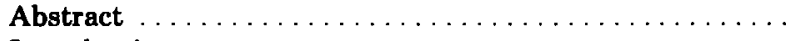 & 1 \\
\hline Introduction $\quad \ldots \ldots \ldots \ldots \ldots \ldots \ldots \ldots \ldots \ldots \ldots$ & 2 \\
\hline Acknowledgments $\ldots \ldots \ldots \ldots \ldots \ldots \ldots \ldots \ldots$ & 2 \\
\hline Regional geology $\ldots \ldots \ldots \ldots \ldots \ldots \ldots \ldots \ldots$ & 2 \\
\hline Previous work $\ldots \ldots \ldots \ldots \ldots \ldots \ldots \ldots \ldots \ldots \ldots \ldots \ldots \ldots \ldots \ldots \ldots$ & 5 \\
\hline General description of the La Jencia fault $\ldots \ldots \ldots \ldots \ldots$ & 7 \\
\hline Trench investigations $\ldots \ldots \ldots \ldots \ldots \ldots \ldots \ldots$ & 8 \\
\hline Introduction $\ldots \ldots \ldots \ldots \ldots \ldots \ldots \ldots \ldots \ldots \ldots \ldots \ldots$ & 8 \\
\hline Methods . . & 9 \\
\hline Excavations $\ldots \ldots \ldots \ldots \ldots$ & 10 \\
\hline Describing and mapping units . . & 10 \\
\hline Soil nomenclature and horizontal designation $\ldots \ldots \ldots$ & 10 \\
\hline Trench $1 \ldots \ldots \ldots \ldots \ldots \ldots \ldots$ & 13 \\
\hline$\ldots \ldots \ldots \ldots \ldots \ldots \ldots \ldots \ldots \ldots \ldots$ & 13 \\
\hline Geologic investigations $\ldots \ldots \ldots \ldots \ldots \ldots$ & 14 \\
\hline Summary $\ldots \ldots \ldots \ldots \ldots \ldots \ldots \ldots \ldots$ & 19 \\
\hline 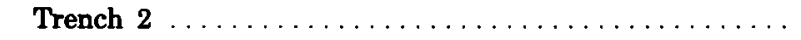 & 19 \\
\hline Setting $\ldots \ldots \ldots \ldots$ & 19 \\
\hline Geologic investigations $\ldots \ldots \ldots \ldots \ldots \ldots$ & 22 \\
\hline 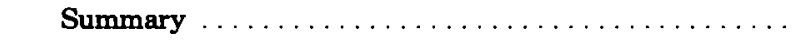 & 30 \\
\hline Trench $3 \ldots$ & 30 \\
\hline 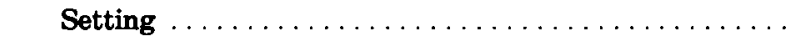 & 30 \\
\hline Geologic investigations $\ldots \ldots \ldots \ldots \ldots \ldots \ldots$ & 31 \\
\hline Summary $\ldots \ldots \ldots \ldots$ & 43 \\
\hline Trench $4 \ldots$ & 43 \\
\hline
\end{tabular}

Trench investigations-Continued Trench 4-Continued Setting $\ldots \ldots \ldots \ldots \ldots \ldots \ldots \ldots \ldots \ldots \ldots \ldots, 43$ Geologic investigations $\ldots \ldots \ldots \ldots \ldots \ldots \ldots \ldots, \quad 44$

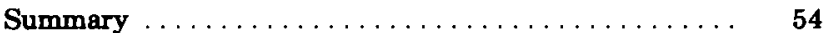
Summary of trench investigations $\ldots \ldots \ldots \ldots \ldots \ldots .54$

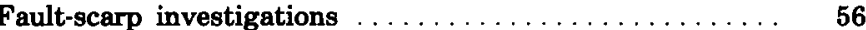
Introduction $\ldots \ldots \ldots \ldots \ldots \ldots \ldots \ldots \ldots \ldots \ldots \ldots$ Scarp profiles and morphometric nomenclature $\ldots \ldots \ldots \quad 56$ Factors affecting fault-scarp degradation . . . . . . . . . 58 Scarp morphology as an indicator of age . . . . . . 59 Scarp-profile data and fault segmentation .......... 60 Discussion of scarp-profile data $\ldots \ldots \ldots \ldots \ldots \ldots \ldots \ldots, 62$ Age calculations for the La Jencia fault scarps . . . . . 64 Rates of scarp degradation $\ldots \ldots \ldots \ldots \ldots \ldots \ldots \ldots .64$ Summary of scarp-morphology investigations ....... 67 Summary of investigations of trenches and fault scarps ... 68 Seismicity of the region $\ldots \ldots \ldots \ldots \ldots \ldots \ldots \ldots \ldots, 69$

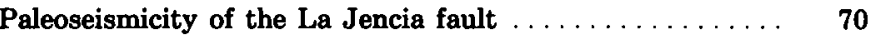
Implications for seismicity in the Rio Grande rift . . . . 72 References cited $\ldots \ldots \ldots \ldots \ldots \ldots \ldots \ldots \ldots \ldots \ldots, \quad 72$ Description of soil horizons in trench $1 \ldots \ldots \ldots \ldots \ldots \ldots, \mathbf{7 4}$ Description of soil horizons in trench $2 \ldots \ldots \ldots \ldots \ldots \ldots .75$ Description of soil horizons in trench $3 \ldots \ldots \ldots \ldots \ldots .76$ Description of soil horizons in trench $4 \ldots \ldots \ldots \ldots \ldots .79$

\section{ILLUSTRATIONS}

[Plates are in pocket]

Plate 1. Geologic units and soil horizons exposed in walls of trenches 1-4 across the La Jencia fault, central New Mexico. 2. Map showing the La Jencia fault and geology of the surrounding area, central New Mexico.

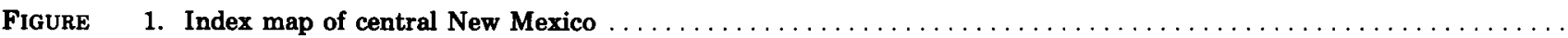

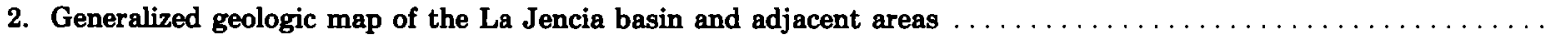

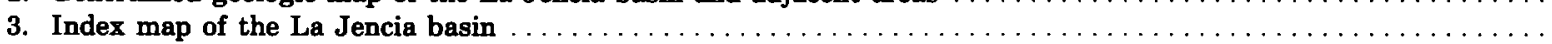

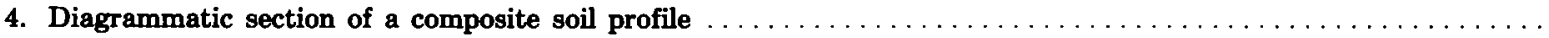

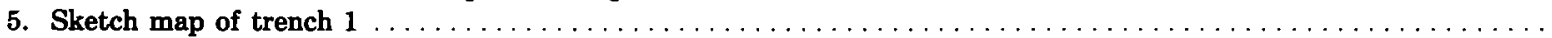

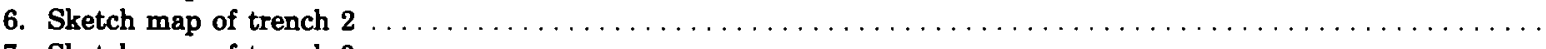

7. Sketch map of trench 3

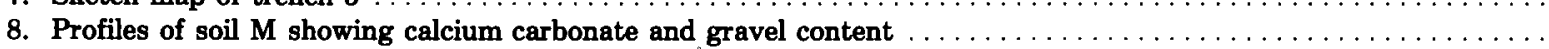

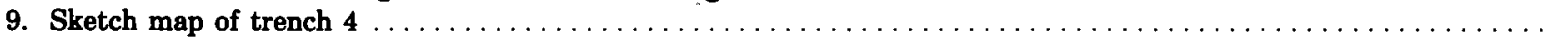

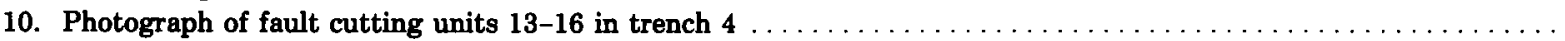

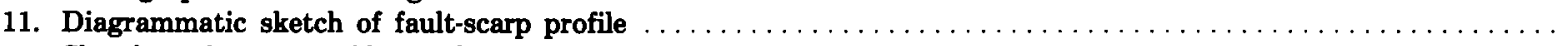

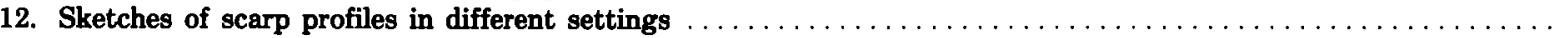

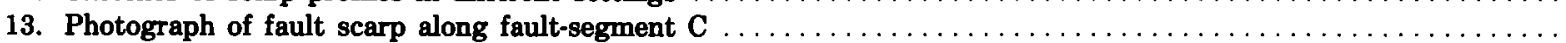

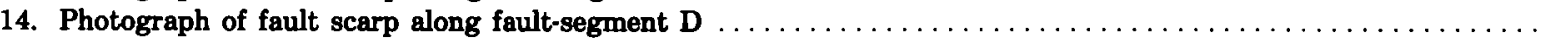




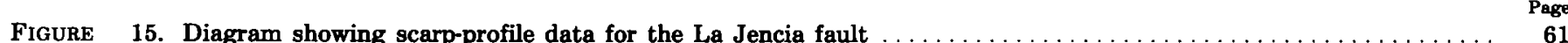

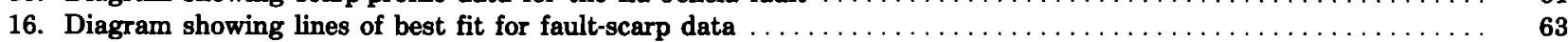

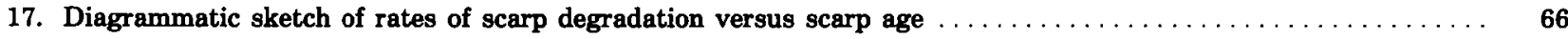

\section{TABLES}

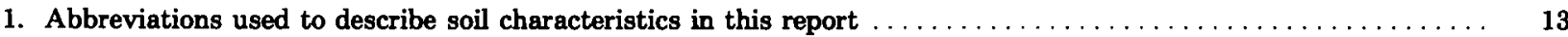

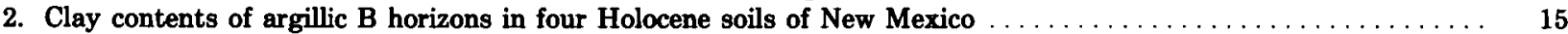

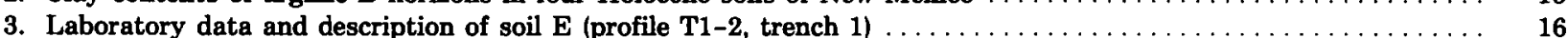

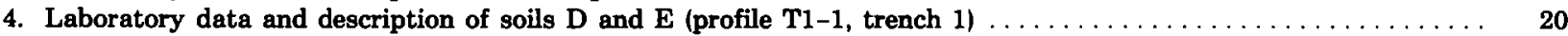

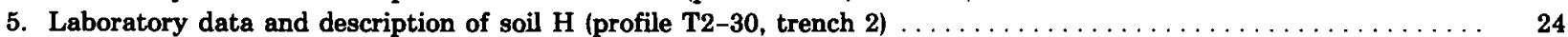

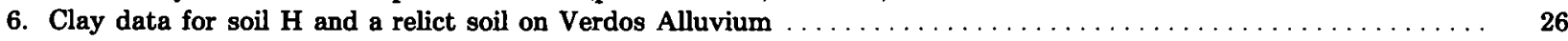

7. Laboratory data and description of soil $\mathbf{G}$ and soil $\mathbf{H}$ (profile $\mathbf{T 2}-\mathbf{3 2}$, trench 2) $\ldots \ldots \ldots \ldots$

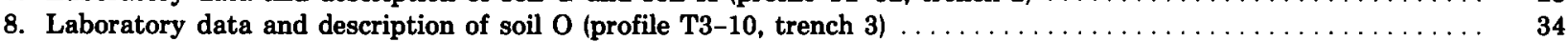

9. Laboratory data and description of soil $M$ and soil $O$ (profile $\mathbf{T 3 - 1 4}$, trench $\mathbf{3}$ ) $\ldots \ldots \ldots \ldots \ldots \ldots$

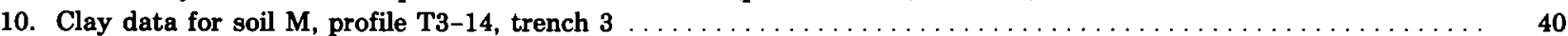

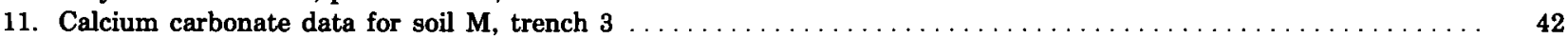

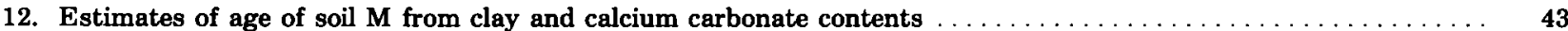

13. Laboratory data and description of soil $W$ (upper part of profile $\mathbf{T} 4 \mathbf{- 1}$, trench 4$) \ldots \ldots \ldots \ldots$

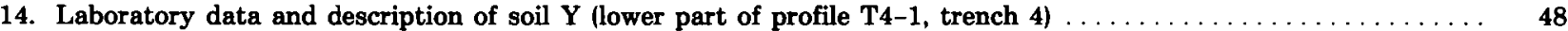

15. Laboratory data for soil $W$ and soil $X$ (profile $\mathbf{T 4 - 2 1}$, trench 4) $\ldots \ldots \ldots \ldots \ldots \ldots$

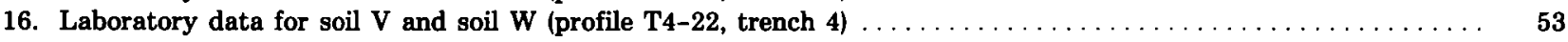

17. Estimated ages of fault movements and amounts of offset observed in trench exposures $\ldots \ldots \ldots \ldots \ldots$

18. Regression equations of maximum scarp-slope angle on the logarithm of scarp height $\ldots \ldots \ldots \ldots \ldots$

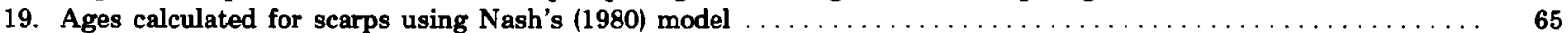

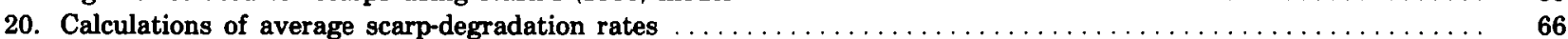

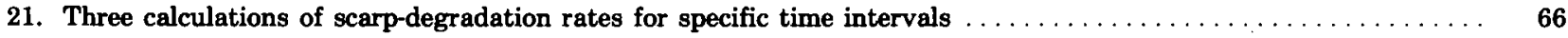

22. Length, maximum offset, and age of movement along segments of the La Jencia fault . . . . . . . . . 68

23. Calculated magnitudes of prehistoric earthquakes along the La Jencia fault $\ldots \ldots \ldots \ldots \ldots \ldots$ 


\title{
QUATERNARY MOVEMENT ALONG THE LA JENGIA FAULT, CENTRAL NEW MEXICO
}

\author{
By Michael N. MachetTe
}

\section{ABSTRACT}

The La Jencia fault is a recently reactivated late Cenozoic basinmargin structure of major proportions that forms the western margin of the Rio Grande rift, which borders the eastern sides of the northern Magdalena Mountains and the southern Bear Mountains in central New Mexico. Stratigraphic throw on the fault has not been determined, but Precambrian rocks of the Magdalena Mountains are uplifted a minimum of $800 \mathrm{~m}$ (meters) above the adjacent basin floor, below which lie a thick section of upper Cenozoic basin-fill deposits. Most of the implied displacement is probably Neogene in age.

The most recent movements on the La Jencia fault produced a series of prominent but low scarps, generally less than $7 \mathrm{~m}$ high, that extend almost continuously north-south for $35 \mathrm{~km}$ (kilometers). Deposits of middle (and early?) Pleistocene age to middle Holocene age are displaced similar amounts along the La Jencia fault. At the southern and northern ends of the fault, the scarps progressively decrease in height and step basinward (east) in an en echelon pattern.

Bedrock is exposed in fault contact with Quaternary deposits at only one location along the La Jencia fault, in a small outlier of Precambrian rock $500 \mathrm{~m}$ east of the mountain front. Elsewhere, the fault forms scarps several hundred meters basinward of the nearest exposures of bedrock. The contact between Quaternary deposits and bedrock is sinuous with deep embayments extending into the mountains, evidence which suggests a long period, about $1 \mathrm{Ma}$ (Mega-annum or million years) or more, of relative tectonic stability and progressive evolution of the landscape. This interval of quiescence was punctuated by late Quaternary movement along the La Jencia fault.

Four exploratory trenches were excavated in unconsolidated Quaternary alluvial and eolian deposits of various ages across scarps of the La Jencia fault. Age estimates are given for fault events based on the degree of development, in both qualitative and quantitative terms, of buried and surface soils exposed in the trenches. Calculations of numerical ages for these soils are based on secondary clay and (or) calcium carbonate contents, and the rates of accumulation of these soil components are based on either regional data or comparison with rates determined from soils developed on local deposits of known age.

In the most southerly and northerly trenches (1 and 4, respectively), the combined stratigraphic, structural, and soil evidence indicates that at least three and possibly four discrete episodes of surface rupturing occurred on fault-segments A (southern), C (central), and $\mathbf{E}$ (northern) during the Holocene (past 10,000 years). In the other two trenches $(2$ and 3$)$, the geologic evidence suggests that central parts of the fault (segments B and D) last moved about $15 \mathrm{ka}$ ago and $33 \mathrm{ka}$ ago (ka, kilo-annum or thousand years), respectively. Evidence in trenches 3 and 4 suggests an episode of still older surface rupturing along the northern one-third of the fault (segments D, E, and F) about 150 ka ago.
The relations between maximum scarp-slope angle and scarp height indicate different times for the most recent movement along segments of the La Jencia fault; the scarp morphology supports the same fault history as determined from stratigraphic studies of the four trenches. Fault-segments A (near trench 1) and C (south of trench 3) have scarp morphologies similar to those of the Cox Ranch part of the Organ Mountains fault of southern New Mexico. These fault scarps are thought to have formed in the past 4,000 to 5,000 years. Scarps along fault-segment $B$ (near trench 2) have morphologies that are identical to scarps of the highest wave-cut shoreline of the late Pleistocene Lake Bonneville in Utah; both are here considered to be about $15 \mathrm{ka}$. An older segment (D) of the La Jencia fault (near trench 3 ) has scarps that are morphologically more degraded than those of segment $B$ and of the Bonneville shoreline.

Scarp ages calculated from the scarp-degradation model published by D. B. Nash in 1980 are about $17 \mathrm{ka}$ for fault-segment $D$; this time of movement is here considered to be an absolute minimum. On the basis of the contents of both clay and calcium carbonate in soils developed on scarp colluvium at trench 3 , the most recent movement of fault-segment $D$ is estimated to have been about $33 \mathrm{ka}$ ago. The times of fault movements interpreted in trench $1(5 \mathrm{ka} \mathrm{ago})$ and in trench 3 (33 ka ago) suggest significant changes in rates of scarp degradation during the late Quaternary. The degradation rates range from an average of $10.2 \times 10^{-4} \mathrm{~m}^{2} / \mathrm{yr}$ (square meter per year) for the Holocene to as little as $2.4 \times 10^{-4} \mathrm{~m}^{2} / \mathrm{yr}$ for the latest Pleistocene. The difference is best explained by a more extensive vegetative cover, and hence a more stable landscape, during the latest Pleistocene than during the Holocene.

The combined evidence from trench and scarp investigations, detailed soil descriptions, and laboratory analyses supports an interpretation of five or six separate surface ruptures along five discrete segments of the La Jencia fault. These movements occurred from about $33 \mathrm{ka}$ ago to less than $3 \mathrm{ka}$ ago, an interval of 30,000 years. During the past 33,000 years, the calculated average recurrence interval for movement on the La Jencia fault is as much as 7,500 years, if a minimum of five ruptures occurred, and as little as 6,000 years if a maximum of six surface ruptures occurred.

Estimates of the maximum magnitude of prehistoric earthquakes associated with late Pleistocene and Holocene movement along the La Jencia fault range from Richter magnitude 6.8 to 7.2 (best value about 7.0) and moment magnitude 6.6 to 7.0 (best value about 6.7). These magnitudes are commonly associated with moderate to extensive ground breakage and property damage, and potential loss of life. These estimates of paleoseismicity are based on various combinations of surface-rupture length, surface offset, and source length and width for segments of the fault and for the entire fault. The Quaternary history of movement along the La Jencia fault may be characteristic of a style of tectonism that is more widespread in the Rio Grande rift than previously recognized. 


\section{INTRODUCTION}

The Rio Grande rift is a Neogene topographic and structural feature which, as a result of work published principally since 1970 , is one of the best documented continental rifts in the World. Unfortunately, an analysis of the neotectonics of the rift is hampered by the absence of detailed studies of its Quaternary faults. Published tectonic maps such as those by Woodward and others (1975) are valuable compilations inasmuch as they offer a broad overview of the regional, and to a lesser extent local, tectonic picture, but they are less useful in the evaluation of patterns, rates, and ages of recent tectonism, goals which are important in terms of seismic-hazards planning. Hawley's (1978) compilation of local and regional geology of the rift is invaluable, but it also does not treat fully many of the young features that are of tectonic interest.

In the past few years, significant advances in neotectonic studies have taken place. Detailed investigations involving exploratory trenches and mapping of surficial geology have become commonplace in some parts of the western United States (Sieh, 1978; Dodge and Grose, 1979; Swan and others, 1980). However valuable these types of study are, they remain costly, site specific, and time consuming. In addition to these standard approaches of fault studies, several new methods of analysis have been developed recently. In 1977, Wallace published a benchmark paper showing the significance of timerelated geomorphic features of fault scarps. Wallace's concepts were further refined by Bucknam and Anderson (1979) in their empirical study of the relation between the height and slope angle of some Quaternary scarps in Utah. Nash's (1977 and 1980) quantitative studies of transport on hillslopes and morphologic changes in dated beach escarpments have direct application as relative age-dating techniques in neotectonics.

The types of studies mentioned above constitute state-of-the-art investigations of recent faulting. It seemed logical to apply similar procedures to the study of a young fault, here named the La Jencia fault, within the Rio Grande rift, an area where few detailed studies have been attempted. Such a study would have the following basic objectives: (1) to determine, as accurately as possible, both the recency and recurrence of movement on a major Quaternary fault; (2) to study and calibrate the time-dependent relation between the height and the maximum slope angle of scarps along this fault; (3) to compare this relation to those developed for scarps in Utah by Bucknam and Anderson (1979); (4) to investigate the possibility of nonsynchronous movements along segments of the fault; and (5) to estimate the probable magnitudes of prehistoric earthquakes along the fault. In assessments of the potential seismic hazards that such faults represent, segmentation and fault history are commonly poorly documented.

The La Jencia fault was chosen for this study because it is marked by a fairly continuous, 35-km-long scarp developed on well-exposed, unconsolidated deposits of varying Quaternary age, is believed to form the western margin of the Rio Grande rift and thus is a fundamental structure, and has been largely unstudied except for brief references to its location and acknowledgment of its recent age.

\section{ACKNOWLEDGMENTS}

This report was prepared with the help and advice of many individuals. Elmer Baltz (U.S. Geological Survey) suggested the study, negotiated contracts for trenching, and obtained permission to excavate the trenches. John Hawley (New Mexico Bureau of Mines and Mineral Resources) generously gave his time and expertise during the field studies. Leeland Gile (retired, U.S. Soil Conservation Service) visited the trenches and furnished unpublished data for soils from southern New Mexico.

William Seager (New Mexico State University, Las Cruces), Peter Birkeland, Ted Walker, and William Bradley (University of Colorado, Boulder), and Manuel Bonilla (U.S. Geological Survey) commented on geologic and pedologic features exposed in the trenches. I appreciate the comments of scientists from the U.S. Forest Service, U.S. Soil Conservation Service (SCS), U.S. Bureau of Land Management, and U.S. Bureau of Reclamation who visited the trench sites during the field investigations. Don Hudgins of Socorro, N. Mex., and Junior Gutierrez and his family of Magdalena, $N$. Mex., allowed access and permission to excavate trenches on their property.

Robert Bucknam (U.S. Geological Survey) provided a computer program for plotting and statistical analysis of fault scarps, and Steven Colman (U.S. Geological Survey) provided computer assistance and helped measure some scarp profiles in the field. David Lidke and Game McGimsey (U.S. Geological Survey) assisted me in the field; I appreciate their cooperation and enthusiasm under less than ideal working conditions. I also thank Donald Cheney (U.S. Geological Survey), who analyzed most of the soil samples.

\section{REGIONAL GEOLOGY}

The La Jencia basin (fig. 1) is about $20 \mathrm{~km}$ northwest of Socorro, N. Mex., and is bounded by the Magdalena and Bear Mountains to the west, Ladron Mountains to the north, and Socorro and Lemitar Mountains to the 


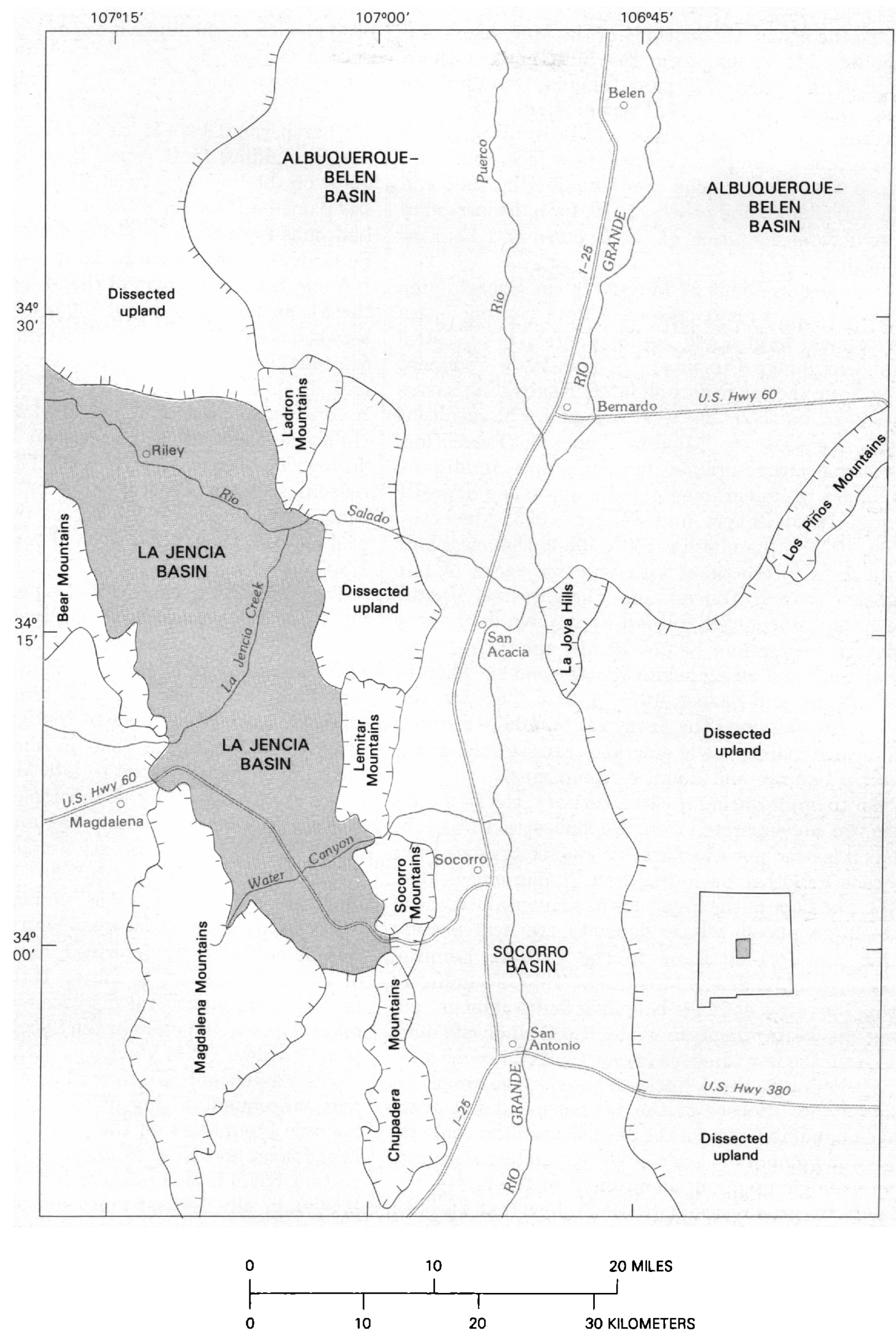

FIGURE 1.-Index map of central New Mexico showing the study area. 
east. To the south, the foothills of the Magdalena and Chupadera Mountains form the indistinct southern margin of the basin. The mountains surrounding the basin ronsist mainly of Precambrian, Paleozoic, Oligocene, and Miocene rocks which, by progressive rotation during the late Tertiary, now form moderate to steep west-tilted blocks. (See Chamberlin, 1980 and 1983, and Chapin and others, 1978, for a discussion of the structural evolution of the Socorro and Lemitar Mountains.)

Rifting began about $27 \mathrm{Ma}$ ago in the Socorro area of New Mexico. A major episode of block faulting in this area formed a large north-trending horst, the ancestral Magdalena Range (Chapin and Seager, 1975). Sediment eroded from the range accumulated in subsiding basins on its east, north(?), and west margins. The resultant bolson deposits, the Miocene Popotosa Formation, range from coarse-grained fanglomerates, mudflows, and lahars to fine-grained gypsiferous playa deposits (Denny, 1940; Chapin and Seager, 1975; Machette, 1978a, 1978b; Chamberlin, 1980, 1983), the basal part of which is interbedded with volcanic rocks of late Oligocene to early Miocene age. The ancestral Magdalena Range was largely buried by its own debris (the Popotosa Formation) before $10 \mathrm{Ma}$ ago, prior to renewed uplift and tilting in late Miocene and (or) Pliocene time (Chapin and Seager, 1975, p. 314). The late Tertiary uplift exhumed the ancestral Magdalena Range and formed major, newly emergent ranges such as the Socorro, Ladron, and Lemitar Mountains.

Prior to uplift during the late Tertiary, the La Jencia basin was not separated from the main structure of the rift as it is now, but was part of a much more extensive Miocene Popotosa basin (fig. 5 in Chapin and Seager, 1975). The floor of the Popotosa basin contained one or more large playas whose deposits are now present within and (or) adjacent to the Ladron, Lemitar, Socorro, and Magdalena Mountains. Thus, a significant part of the throw on range-bounding faults of mountains along the western margin of the Rio Grande rift must date from the late Miocene and (or) early Pliocene (lateor post-Popotosa time). Rocks exposed in the ranges are generally not exposed on the downdropped side of the range-bounding faults (in the basins); therefore, only the minimum amount of Cenozoic throw can be determined from geologic mapping along most of the faults.

Sanford's geophysical data (1968) show that the basin fill (Popotosa and younger sediment) is about $900 \mathrm{~m}$ thick just east of the Socorro Mountains near Socorro (fig. 2). The geophysical data and drilling also suggest a similar thickness of fill in the southern part of the La Jencia basin. The upper part of the Popotosa Formation on Socorro Peak is largely covered by colluvium derived from the 9-Ma rhyolite flows that are inter- bedded with it: the highest exposure of Popotosa Formation mapped by Chamberlin $(1980,1982)$ is about $500 \mathrm{~m}$ above the piedmont at the range-bounding fault of the Socorro Mountains (see also cross section G-G' of Chamberlin, 1982). If the late Cenozoic throw on the range-bounding fault (zone) is assumed to total the uplift on the Popotosa Formation (minimum of $500 \mathrm{~m}$ ) and if one-half $(450 \mathrm{~m})$ of the adjacent basin fill is Sierra Ladrones Formation (post-Popotosa part of the Santa Fe Group), then the throw is at least $950 \mathrm{~m}$.

Along the central part of the Magdalena Mountains there is an average of about $800 \mathrm{~m}$ of topographic relief between the range crest and adjacent basin floor. Early Miocene to late Oligocene volcanic rocks are present at high levels of the range and on its rotated backslopes. A considerable but unknown thickness of Miocene to Holocene basin fill is present on the downdropped (basin) side of the La Jencia fault. Therefore, by similar reasoning, the structural throw on late Cenozoic volcanic rocks (pre-basin fill) across the La Jencia fault probably exceeds $1,000 \mathrm{~m}$, and may be as much as $1,500 \mathrm{~m}$.

The part of the net throw that is post-Popotosa in age, as at Socorro, cannot be determined, but Chapin and Seager $(1975$, p. 301) showed that the Magdalena Mountains probably had little topographic relief about $10 \mathrm{Ma}$ ago (middle to late Miocene time). Therefore, by analogy, much of the present topographic relief of the Magdalena Mountains $(800 \mathrm{~m}$ above the La Jencia basin) may be attributed to late Miocene or Pliocene block uplift and tilting (extension).

The Popotosa Formation was much deformed as a result of this episode of late Tertiary extension. The Popotosa commonly dips $20^{\circ}-30^{\circ}$ and locally dips as much as $60^{\circ}$, whereas the younger basin fill (the Pliocene to middle Pleistocene Sierra Ladrones Formation) is only slightly deformed, having local attitudes of $10^{\circ}-20^{\circ}$ adjacent to major Tertiary faults. These faults record structural displacements of as much as several hundred meters in the Sierra Ladrones Formation (Hawley, 1978; Machette, 1978a).

The La Jencia basin formed as a result of the uplift and subsequent tilting of the Ladron, Lemitar, and Socorro Mountains on the east, and the uplift of the Magdalena and Bear Mountains on the west; the resultant basin is elongate north to south and probably is structurally deepest in its southwestern corner. At its northern end, deposits of the Sierra Ladrones Formation that filled the basin lie in angular unconformity on Popotosa and older rocks (Denny, 1940; Machette, 1978a, 1978b). In this area, the Sierra Ladrones was derived from uplifted ranges to the east, which shows that the northern part of the La Jencia basin was closed in the Pliocene. However, at the south 
end of the basin, basalt erupted from two vents east of Sedillo Hill Reservoir (fig. 2) about $4 \mathrm{Ma}$, flowed eastward through Socorro Canyon, and spilled onto the flood plain of the ancestral Rio Grande near Socorro. Thus, it appears that by early Pliocene time ( $4 \mathrm{Ma}$ ago) the southern part of the La Jencia basin had become an integrated subbasin of the Rio Grande system. Episodic Pliocene to Pleistocene down-to-the-west movement along a major fault about $2 \mathrm{~km}$ east of Sedillo Hill Reservoir intermittently blocked drainage from this end of the basin. Geothermal wells drilled west and east of this fault show that the Sierra Ladrones Formation may be more than $500 \mathrm{~m}$ thick (G. R. Osburn, oral commun., 1979). This data and the pattern of Cenozoic faulting along the Magdalena and Bear Mountains suggest that the basin may, in fact, contain a southwardthickening wedge of Miocene to Pleistocene basin fill.

The small, modern playa near the center of the basin (pl. 2) is a remnant of the once internally drained La Jencia basin. This playa now lies on the modern drainage divide between the north and south subbasins of the La Jencia that drain to the Rio Grande. North of this divide, the relict constructional floor of the La Jencia basin is still widely preserved and is marked by a well-developed calcic soil (nomenclature of Bachman and Machette, 1977), and by local travertines (Denny, 1941; Bachman and Machette, 1977; Barker, 1983) that form mesas above the deeply incised canyons of $\mathrm{La}$ Jencia Creek and the Rio Salado (fig. 2; see also Bachman and Machette, 1977, fig. 11). Comparison of this soil with soils in the Albuquerque-Belen basin to the northeast (fig. 1) suggests an age of $300-500$ ka for much of the relict constructional floor of the La Jencia basin (age based on data of Machette in Chamberlin and others, 1983, p. 37). This surface is deeply incised by the Rio Salado and its tributary streams; downstream (to the east) along the Rio Salado a sequence of alluvial terraces record progressive downcutting as the base level along the Rio Grande was lowered. The oldest terrace preserved along the Rio Salado was deposited about $220 \mathrm{ka}$ ago (Machette in Hawley, 1978, p. 135). On the basis of soils data (Bachman and Machette, 1977; this study), I believe that drainage from the northern part of the La Jencia basin became integrated with the Rio Grande at $400 \mathrm{ka}$ ago, and drainage from the southern subbasin was integrated with the Rio Grande slightly earlier, perhaps about $600 \mathrm{ka}$ ago.

Most of the materials present in the trenches and in natural exposures in the La Jencia basin are of Holocene to middle Pleistocene age and thus fit well in the drainage history I have reconstructed for the basin. However, remnants of early(?) Pleistocene alluvial fans scattered around the basin must predate the basin's integration with the Rio Grande drainage system.
With the exception of the larger stream channels (pl. 2), most of the small ephemeral streams that flow in channels and arroyos in the basin are unrelated to the present external drainage. La Jencia Creek and the Rio Salado are the only streams in the basin that are capable of sustained transport of sediment, and material eroded from the eastern sides of the Magdalena and Bear Mountains during large-scale summer thunderstorms is carried by ephemeral streams and is subsequently deposited on the piedmont slope in small alluvial fans and in the arroyos as channel-filling deposits. Most of the material presently being deposited in the basin probably is eroded from soils and alluvium exposed on the piedmont slope adjacent to the mountains. The recycling of these materials greatly influences the nature of the resulting unconsolidated deposits and the soils that have formed on them.

\section{PREVIOUS WORK}

The La Jencia fault was recognized by Kirk Bryan (written commun., 1933, in Loughlin and Koschmann, 1942) as having a youthful fault scarp. The detailed geologic map of the Magdalena Mountains by Loughlin and Koschmann (1942) did not extend far enough east to include the La Jencia fault. Although these workers recognized the fault's geomorphic and structural significance, no detailed investigation of the fault was conducted until the present study. In the late 1930's, C. S. Denny, one of Kirk Bryan's students, started detailed mapping of the basin deposits near San Acacia (fig. 1) and established a stratigraphic framework for the Tertiary basin-fill and Quaternary surficial deposits (Denny, 1940, 1941). Recent work by Chapin and Seager (1975), by numerous graduate students under Chapin's supervision, and by Machette (1978a, 1978b) has helped refine the Tertiary stratigraphic, structural, and geologic history of this part of the Rio Grande rift.

Weber and Willard (1963) noted the location of the La Jencia fault and referred to it as "Recent" (Holocene) in age. The first published map showing the fault was that of Sanford and others (1972). This map, compiled primarily by photogeologic methods, shows the location of Quaternary faults and suspected Quaternary faults within the Rio Grande rift, from Isleta on the north (30 km north of Belen) to San Antonio on the south (fig. 1). Generalized geologic units and earthquake epicenters are also shown on their map. Sanford and others (1972, table 6, fault no. 1) described the La Jencia fault scarp as being $34 \mathrm{~km}$ long and having a maximum displacement (scarp height?) of $10 \mathrm{~m}$, which, according to their model of paleoseismicity, may have been produced by a single earthquake of magnitude 7.9 ! 


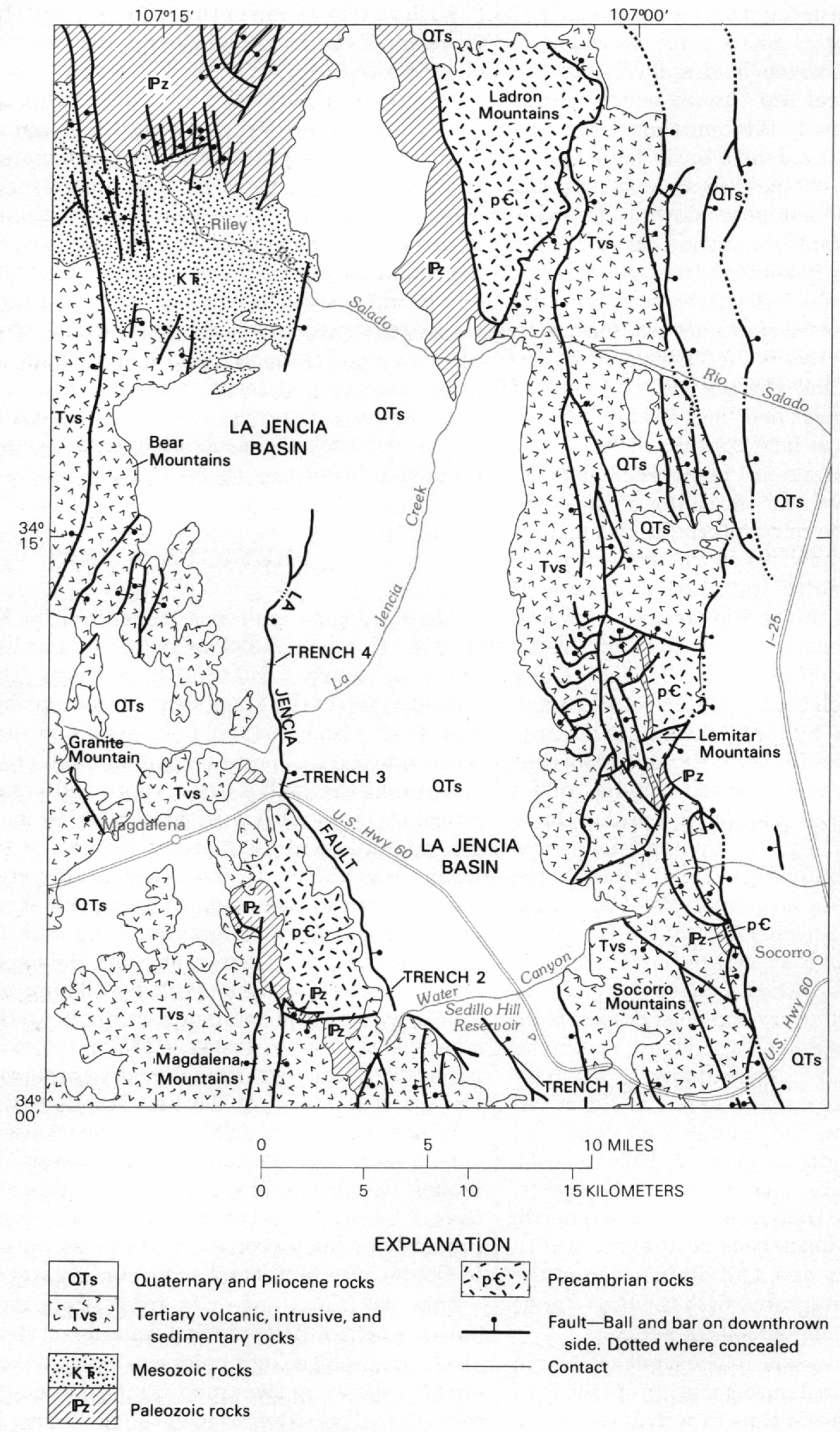

FIGURE 2.-Generalized geologic map of the La Jencia basin, New Mexico, and adjacent areas. Simplified from Machette (1978b). 
Chapin and others $(1978$, p. 8$)$ noted the location and size (32-km length, 9-m displacement) of the fault scarp, and they argued, logically, that the fault is "probably post-Wisconsin in age because sand plumes [deposits] derived from dissection of pluvial lakes on the San Agustin Plains are offset." White Lake (Markgraf and others, 1984), about $40 \mathrm{~km}$ west of Magdalena, is the northernmost of the pluvial lakes. The marked lowering of the lake 12-13 ka ago (Weber and Sterns, 1965) exposed a broad basin to eolian erosion. Deposition of sand downwind (toward Magdalena) formed a plume of sand that is easily recognized on high-altitude aerial photographs; the sand is funneled further to the northeast through a gap between Granite Mountain and the southern part of the Bear Mountains (fig. 2), where it extends partly into the La Jencia basin (pl. 2).

In summary, the La Jencia fault, one of the longer and younger faults of the Rio Grande rift in New Mexico, was first noted in 1933 and has been the subject of several cursory photogeologic studies. Although no detailed investigations of this fault were made prior to the present study, the existing literature shows only that the fault is $32-34 \mathrm{~km}$ long and has 9 - to $10-\mathrm{m}$ high scarps that are considered latest Wisconsin or Holocene in age. In retrospect, these statements have proven to be fairly accurate, although generalized, characterizations of the La Jencia fault.

\section{GENERAL DESCRIPTION OF THE LA JENCIA FAULT}

The La Jencia fault, which borders the Magdalena and Bear Mountains (fig. 3), is generally marked by a single, fairly continuous scarp that may be either the expression of a single fault or the only active fault in a broad fault zone. I infer that at least $800 \mathrm{~m}$ of Tertiary stratigraphic throw is present on this fault, based on uplifted rocks in the adjacent mountains.

For this study, the 35-km-long fault was divided into three geographic parts: a southern part consisting of a single 5-km-long segment (A) extending from $1.5 \mathrm{~km}$ south of Water Canyon south to Sixmile Canyon (fig. 3, pl. 2); a 23.8-km-long central part consisting of four segments (B, C, D, E) from $1.5 \mathrm{~km}$ south of Water Canyon north to about $3.5 \mathrm{~km}$ past La Jencia Creek; and a northern part consisting of a 5.6-km-long segment (F) that extends to the dissected terrain of the north-central La Jencia basin. This report deals primarily with the southern and central parts of the fault. The northern part generally consists of a wide, dissected piedmont slope area that has a thin cover of eolian sand and poorly preserved, low, discontinuous fault scarps. Exposures in this part of the basin are generally poor.
Figure 3, a reduced and simplified version of the generalized geologic map (pl. 2) along the La Jencia fault, shows the fault and its segments, and trench sites. Along the central part of the fault, the scarp is nearly continuous for $19 \mathrm{~km}$ from the windmill in sec. 30 , T. 1 S., R. $3 \mathrm{~W}$. (pl. 2) on the north, to $1.5 \mathrm{~km}$ south of Water Canyon in sec. 14, T. 3 S., R. 3 W., on the south. The scarp is entirely within Quaternary deposits, generally about 250 to $750 \mathrm{~m}$ east of the mountain front, except west of the S. Strozzi Ranch (sec. 11, T. 3 S., R. 3 W., pl. 2) where the fault bounds the eastern side of a small, isolated outlier of Precambrian rock. This is the only place along the entire length of the fault where bedrock is exposed against the fault.

The southern $5 \mathrm{~km}$ of the central part of the fault is partly obscured by a thick, active mantle of colluvium on the steep northeastern side of the mesa southeast of Water Canyon (sec. 24, T. 3 S., R. 3 W., and secs. 19 and 30 , T. 3 S., R. 2 W.). Here, the scarp becomes discontinuous and has splays; it forms several lineations that were noted on aerial photographs. None of these features extend south of South Canyon, where they probably have been eroded.

The southern part of the La Jencia fault consists of a single 5-km-long fault segment (A) that lies about $1.5-2 \mathrm{~km}$ basinward of the mountains. This segment is marked by a continuous and generally low fault scarp. It can be traced from the small stock tank in the northeastern part of sec. 19 (T. 3 S., R. 2 W., pl. 2) to the boundary between secs. 28 and 33 (T. 3 S., R. 2 W.) where it divides into two small scarps, the most easterly of which can be traced the farthest, about $1.2 \mathrm{~km}$ southeast to Sixmile Canyon.

The northern part of the fault (segment F) extends about $2 \mathrm{~km}$ beyond the northern boundary of the map area (fig. 3, pl. 2). The total length of the surface expression of the La Jencia fault is $34.6 \mathrm{~km}$, as measured along its smoothed trace. A total length of $35 \mathrm{~km}$ is used in subsequent discussions and in calculations of earthquake magnitude.

Along most of its length, the topographic and geomorphic expression of the fault is that of a single scarp. Generally, the scarp has a simple profile and does not have pronounced compound angles noted in many of Wallace's (1977) examples. However, at several locations along segment $D$, the scarp has a slightly beveled upper slope that may be the remnant of an old degraded scarp formed during a previous rupture. Generally such features are minor and only locally developed. In the area between Ellis Canyon and U.S. Highway 60 (pl. 2, segment $\mathrm{C}$ ), the fault forms a complex pattern of surface ruptures having several narrow zones of double or triple synthetic scarps. These zones end abruptly and 


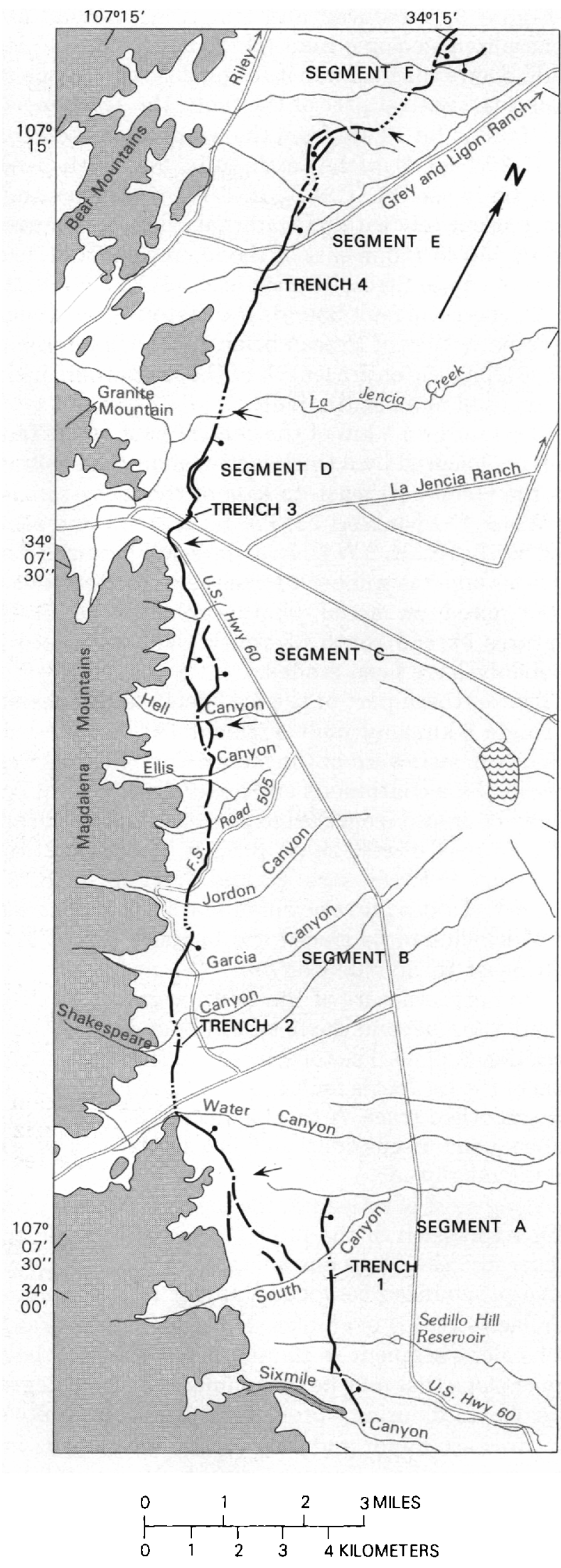

served to transfer motion from one fault surface to an adjacent, overlapping one.

Almost everywhere along the La Jencia fault the main scarp is the product of normal dip(?)-slip, down-to-theeast movement. Along segment $\mathrm{D}$ in sec. 8 (T. $2 \mathrm{~S}$., R. 3 W.; pl. 2) and along parts of segment $E$ in secs. 18 and 19 (T. 1 S., R. 3 W.) the main scarp is paralleled, 100 to $300 \mathrm{~m}$ to the east, by smaller scarps formed by movement on antithetic normal faults. The antithetic scarps generally have one-quarter or less the height of the main fault scarps; together they form broad grabens that locally control drainage from the upthrown block.

The height of scarps along the La Jencia fault ranges from less than $0.5 \mathrm{~m}$ (not discernible on most conventional aerial photographs) to a maximum of $7.4 \mathrm{~m}$. (See the section on "Fault Scarp Investigations" for the graphical method of computing scarp height.) Most of the scarps are 2 to $4.5 \mathrm{~m}$ high, but some short sections exceed $4.5 \mathrm{~m}$ in height. The maximum scarp height was measured near the north end of segment C (pl. 2, scarp profile E, no. M1-33) at the center of sec. 17 (T. 2 S., R. $3 \mathrm{~W}$.) $0.75 \mathrm{~km}$ southeast of the intersection of the fault with Highway 60 . Along segment $E$ (north-central part of the fault), the height of scarps has been greatly reduced by eolian sand that has accumulated on the leeward (downdropped) side of the scarps. In many of these places the present scarp height may reflect only half of the preburial scarp height.

\section{TRENCH INVESTIGATIONS}

\section{INTRODUCTION}

In the late spring of 1978 I conducted a reconnaissance study of the La Jencia fault, noting the location of scarps, their approximate heights and slope angles, and the types of materials that were faulted. Four sites were selected for exploratory trenching to determine the ages, character, and structures of the faulted materials. The goal was to construct a chronology of fault movements, amounts of displacement, and possible temporal variation along the fault's length. The sites were chosen using the following criteria:

1. Geomorphically stable sites were preferred because they may contain a more complete record of prefault and postfault deposits. Adjacent, less stable areas could be used to augment data collected at each trench site.

Figure 3.-Index map of La Jencia basin, New Mexico, showing areas of bedrock (patterned), the La Jencia fault and its segments, and trench localities. Arrows mark boundaries between segments. Modified from plate 2. 
2. Where possible, sites were chosen in areas of maximum vegetative cover because they might have had springs. These sites are inherently stable, and they have the best potential for containing materials suitable for radiocarbon dating.

3. The sites were distributed along the length of the fault to document possible nonsynchronous movement on various segments of the fault. Clustered sites might show only one episode of a complex fault history.

4. The sites were in a variety of materials, ranging from sandy and gravelly alluvial deposits (both piedmont-slope and alluvial-fan deposits) to eolian sand. Previous investigations in Nevada (Dodge and Grose, $1979,1980)$ showed that the texture of some unconsolidated materials have a profound effect on the rate of fault-scarp degradation.

5. Sites were located near roads to minimize the detrimental effects and additional costs of road building. Fortunately, suitable access roads are present throughout most of the study area.

No detailed investigations of young faults or their associated scarps in New Mexico had been made prior to this study. During the course of this study, Leeland Gile (retired, U.S. Soil Conservation Service) and William Seager (New Mexico State University at Las Cruces) were investigating the Organ Mountains fault west of White Sands, in southern New Mexico. They used soil descriptions and laboratory analyses to estimate the age of soils developed on the youngest faulted deposit and the oldest unfaulted deposit, thereby bracketing the most recent episode of surface rupturing. My approach was somewhat different, inasmuch as two of my goals were to investigate fault structures and to evaluate processes of fault-scarp degradation. Although Wallace's (1977) investigation of fault scarps in Nevada is a basic contribution to the latter topic, it does not deal with the three-dimensional aspect of faulting, and the time of faulting in his study is not well controlled. Thus, an effort was made to collect data on scarp morphology and both surface and subsurface geology, utilizing soil development and soil stratigraphy as fundamental tools. The combination of these two allied techniques should yield a more accurate history of faulting than would either technique alone.

\section{METHODS}

The following methods were used in the trench investigations:

1. Gross surficial geologic units were mapped along the fault, and the contact between surficial and bedrock units was mapped in areas not covered by previously published maps (see index, pl. 2). Most of the surficial deposits in the area are poorly exposed, and the mapping relied heavily on interpretation of aerial photo- graphs, inspection of natural exposures (stream cutbanks and arroyos) and manmade exposures, and selective augering of fine-grained materials. Both blackand-white (1:50,000 scale) and color, low-altitude (1:15,800 scale) aerial photographs were used for mapping. The mapped contacts were then transferred to a 1:48,000-scale base of the Magdalena 15-minute quadrangle, using a photogrammetric plotter. The resultant map (pl. 2) is somewhat generalized from the information compiled on the aerial photographs.

2. Topographic profiles were measured perpendicular to the trace of the fault scarp at locations where active erosion or deposition were minimal. Profiles were measured using an Abney hand level, stadia rod, and cloth tape measure (metric). Although this method differs somewhat from that outlined by Bucknam and Anderson (1979), the resultant profiles are of equivalent quality. A minimum of four, and commonly six, measurements of maximum scarp angle were made adjacent to the profile traverse. About $\mathbf{4 0}$ detailed profiles of scarps, which had varying heights and maximum slope angles, were measured along the central and southern parts of the fault (see pl. 2 for locations of profiles). The topographic profiles were analyzed with the aid of computer plotting and statistical-analysis programs.

3. Four exploratory trenches were excavated across the scarp to expose the fault(s), the alluvial, eolian, and colluvial units, and the soils. Structural and stratigraphic relationships exposed in the trench walls and soils developed on various units permitted the construction of detailed trench logs and an interpretation of fault chronologies. Adjacent natural exposures allowed a preview of the nature and age of materials which might be found in all but trench 1 .

4. The trenches were logged (materials described and units differentiated) and mapped at 1:50 scale $(1 \mathrm{~cm}$ equals $50 \mathrm{~cm}$ or centimeters). Both surface and buried soils were described in pedologic terms (Birkeland, 1974; U.S. Department of Agriculture, Soil Conservation Service, 1975) and sampled for laboratory characterization. In addition, one or more samples were collected from each sedimentary and colluvial unit to help characterize their grain size, sorting, and lithology.

5. Laboratory analyses were made on the soil samples. Most soils were analyzed for grain-size distribution, bulk density, and calcium carbonate content, whereas selected samples were analyzed for organic-matter content and $\mathrm{pH}$ values. Laboratory procedures were similar to those used by Machette, Birkeland, Burke, and others (1976).

The characterization of these soils permitted comparison of their degree of development across faults and their correlation with dated soils from chronosequences in other areas. The Las Cruces area, which has been the subject of a long-term desert soils project of the SCS 
(Hawley, 1975; Gile and Grossman, 1979; Gile and others, 1981), has perhaps the best characterized soil chronosequence in the southwestern United States. Quantitative data from studies of calcareous soils and calcretes by Bachman and Machette (1977) and Machette (1985) were also used for comparison and to estimate rates of soil formation in this investigation.

\section{EXCAVATIONS}

In late October, 1978, a trench was excavated at each of the four sites by a commercial excavating company using a small backhoe with a $60-\mathrm{cm}$-wide bucket. This backhoe easily dug a trench 3-3.5 $\mathrm{m}$ deep, which was sufficient to expose the youngest faulted materials and to allow interpretation of young aspects of the fault's history. In this study, the youngest faulted materials were found within the upper $3 \mathrm{~m}$ of the downdropped fault block. A minimum of 1-m penetration into faulted and buried deposits is generally required to assure reasonable correlations across the fault. Where there is more than $5 \mathrm{~m}$ of stratigraphic separation on a fault, deeper excavation would be required on the downdropped block.

The trenches were $1.5 \mathrm{~m}$ wide, 2.5 to $3.5 \mathrm{~m}$ deep, and 20 to $25 \mathrm{~m}$ long. Trench 3 (fig. 3) was later extended on the downdropped block to a total length of $55 \mathrm{~m}$ in an unsuccessful attempt to find fine-grained materials containing carbonaceous matter. An average of 8 hours was required for the excavation of each short trench. The trenches were protected from collapse by wooden $2 \times 6$ in. (inch) boards placed vertically on $1.8-\mathrm{m}$ (6-ft or foot) centers and supported by wooden $4 \times 4$ in. cross members. Additional braces and supports were placed where the trenched materials lacked cohesion (trenches 1 and 4). About 15 man-hours were spent installing the shoring and protective fencing at each site. All four sites remained open from mid-November 1978 until early May 1979. About 40 man-hours and 20 machine-hours were spent backfilling the short trenches and regrading the sites.

DESCRIBING AND MAPPING UNITS

Each trench was mapped at 1:50 scale on mylar film (0.1-mm (millmeter)-thick transparent plastic) over a base of graph paper scaled at 10 units per centimeter. These materials were mounted on a planetable board and tripod that acted as a portable drawing table. One wall of each trench was completely mapped, and the map units and contacts were compared to those on the opposite trench wall. Using this procedure, locations of individual points on the trench wall could be transferred to the map within about $2 \mathrm{~cm}$ of their actual position.
Horizontal level lines (nylon string) were placed along the wall for vertical control, and distances were measured using the vertical shoring as horizontal control stations. The surfaces of the walls were scraped with a trenching tool to remove marks made by the backhoe; then, in areas where soils were developed, the walls were picked out with a knife to reveal pedogenic, sedimentary, and structural features. Contacts between soil horizons, geologic units, and faults were traced and marked with $20 \mathrm{~d}$ (13-cm-long) nails. Color coding the nails helped differentiate the several types of contacts mapped in the trenches. The horizontal and vertical coordinates of individual nail positions were plotted on the mylar base, and contacts were sketched between these control points. Differentiation and description of units, mapping, soil description, sampling, and final checking required from 8 to 12 man-days per trench.

A concerted effort was made throughout the investigations to locate materials which might be suitable for radiometric dating (that is, techniques such as radiocarbon, tephrochronology, fission-track, potassium-argon, uranium isotope, and so forth). Except for an insufficient amount of slightly organic colluvium, datable material was not found in the trenches.

The units mapped in the trenches were considered as both sedimentary layers (geologic units) and soil units (horizons or subhorizons). For example, a gravel layer having pedogenic calcium carbonate might be mapped as a calcareous (Cca) soil horizon of a depositional unit, such as alluvium. Unaltered units were mapped as unweathered $(\mathrm{Cn})$ soil horizons. A discussion of soilhorizon nomenclature follows, inasmuch as soils data constitute the main body of evidence for interpreting times of fault activity.

\section{SOIL NOMENCLATURE AND HORIZONTAL DESIGNATION}

The differentiation of map units in the trenches was based on the presence and development of soil features and on the character of the soil's respective parent materials. A limited number of soil terms are herein defined. The reader should consult Birkeland (1974) or U.S. Department of Agriculture, Soil Conservation Service (1975) for a comprehensive discussion of soil-horizon nomenclature.

The processes of mineral weathering in, or material additions (such as dust or water-soluble minerals) to, an unconsolidated deposit result in the formation of a soil profile which contains horizons, providing the land surface is not being eroded or buried at a rate which exceeds soil formation. The resultant soil may be sufficiently developed to have all of the three common master horizons of a soil profile, the A, B, and C horizons. 
Unconsolidated surficial deposits typically consist of thin, overlapping, or juxtaposed layers which may differ significantly in lithologic composition, grain size, sorting, and compaction. Such variations are used to differentiate changes in parent materials, inasmuch as they greatly affect the resultant development of soil profiles. Soils may extend through one or more parent materials, especially when the parent-material layers are thin.

The parent materials of soils are here noted by Arabic numerals that precede the symbol for master horizon; previously, Roman numerals were used for these designations (U.S. Department of Agriculture, Soil Conservation Service, 1975). These numbers normally increase downward, although faulting may result in older deposits locally overlying younger deposits (stratigraphic reversal). The numerical designation of the youngest material, unit 1, is omitted (fig. 4). The following discussion of soil horizonation follows the usage of Birkeland (1974), which I feel is more applicable to this report than the strict agronomic approach used by the SCS.

The A horizon is a layer of humic organic matter in a mixture of minerals; this layer is generally the uppermost part of a soil (fig. 4). In semiarid and arid parts of the southwestern United States, the A horizon is thin and generally is classified as an ochric epipedon, because it has light color (Munsell value) and a low content of organic matter. In arid climates, silt-rich, calcareous A horizons can rapidly form vesicular structures (for example, the 2Avb horizon, fig. 4).

In semiarid and arid climates, the next lower soil horizon is commonly the B horizon, and although there are many types of $\mathrm{B}$ horizons, only two, the cambic and the argillic, were common in the study area. By definition, the original (sedimentary) structure of a soil's parent material is destroyed during formation of $A$ and B horizons. Argillic B horizons (indicated by the symbol t) are defined as having accumulations of layer-lattice silicate clay as a result of downward movement (illuviation) from overlying horizons, usually the A horizon. Some clay in B horizons may also result from in-place weathering of mineral grains. Movement of clay within a soil is recognized by the formation of clay skins on faces of peds (structural blocks in the soil) or by clay coatings on individual mineral grains. In moderate to advanced development of argillic B horizons, there is a marked increase in clay content relative to adjacent horizons (U.S. Department of Agriculture, Soil Conservation Service, 1975 , p. $26-27$ ).

Cambic B horizons are common in young soils of the study area. I have accepted Birkeland's $(1974$, p. 6) broad usage of the cambic horizon for this report. In this usage, cambic B horizons (indicated by the symbol s) are characterized by sufficient alteration and bioturbation to eradicate most original sedimentary structures (a basic requirement for $\mathrm{B}$ horizons), formation of soil structure (however weak), and removal or redistribution of primary calcium carbonate (or other soluble salts). In dry, hot environments these changes are generally accompanied by the formation of higher soil chromas and (or) redder soil hues, hence the name "cambic" (color). Cambic B horizons generally form in young materials having sandy textures and often are the precursors of argillic B horizons.

The lowest master horizon of a soil is the $\mathrm{C}$ horizon (fig. 4). Although $\mathrm{C}$ horizons are generally below the solum (A and B horizons), they may lie at the surface if the solum has not yet formed or if it has been eroded. The parent material for $\mathrm{C}$ horizons need not be the same as that for the overlying horizons. $\mathrm{C}$ horizons lack the properties of the $\mathrm{A}$ and $\mathrm{B}$ horizons but may include features such as mineral oxidation or alteration, and accumulations of silica, carbonates, or soluble salts (typically gypsum).

The soil nomenclature in this report differs significantly from that used by the SCS (U.S. Department of Agriculture, Soil Conservation Service, 1975) in the use of "K horizon" (Gile and others, 1965) as a master soil horizon, like the $A, B$, and $C$ horizons. The term " $K$ horizon" denotes the part of a soil that has a strong accumulation of calcium carbonate in the position of the C horizon (fig. 4) or, rarely, in the lowest part of the B horizon. An advanced form of a calcareous $C$ horizon (Cca), the $\mathrm{K}$ horizon may eventually become so impregnated by carbonate that the morphology and structure are dominated by the carbonate itself. As defined by Gile and others (1965), the $\mathrm{K}$ horizon has authigenic calcium carbonate which coats or engulfs all primary mineral grains to such an extent that it forms a continuous medium (K-fabric) constituting 50 percent or more of the horizon's volume).

The distribution of calcium carbonate in $\mathrm{C}$ and $\mathrm{K}$ horizons is analogous to that of clay in argillic $\mathrm{B}$ horizons; that is, carbonate is most concentrated near, but below, the top of the horizon, and the concentration gradually decreases downward in the horizon. $\mathrm{K}$ horizons in advanced stages of development have relatively impermeable, cemented laminar subhorizons or multistage breccias (Bachman and Machette, 1977). Recent reports by Gile and others $(1965,1966,1981)$, Bachman and Machette (1977), Gile and Grossman (1979), and Machette (1985) should be consulted for more complete discussions of calcareous horizons in calcic soils.

The four master horizons typically found in soils of this region are divided into subhorizons and labeled using a numerical system. The numbers 1,2 , and 3 denote a first-order subdivision (that is, B1, B2, B3), 1 and 3 being transitional with adjacent master horizons. Additional division of subhorizons is by a two-digit system: 


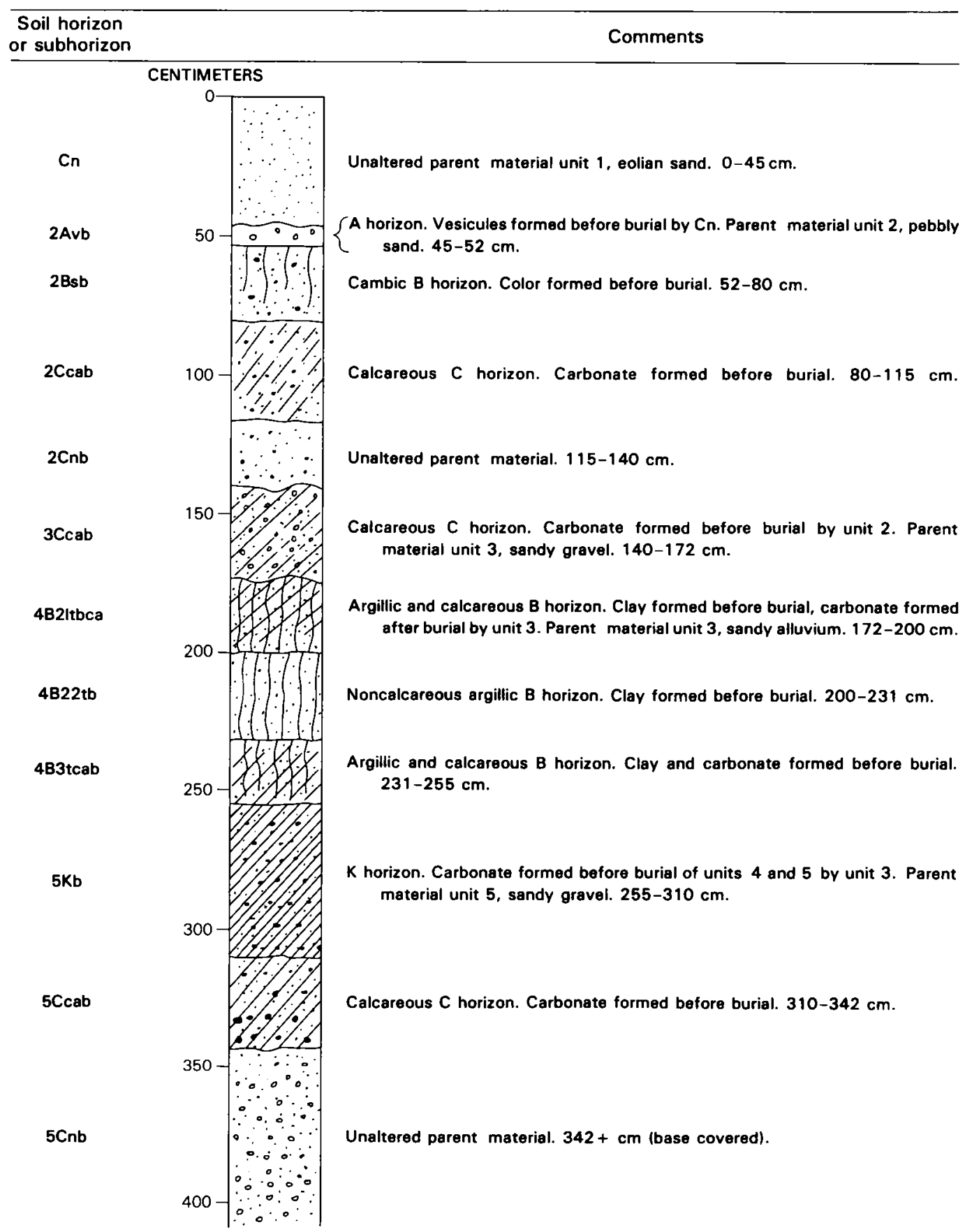

FIgURE 4.-Diagrammatic section of a composite soil profile showing some of the possible horizons and parent-material designations found in soils exposed in trenches excavated across the La Jencia fault.

for example, B21t, B22t, and B23t subhorizons would indicate that the maximum expression of the argillic $B$ horizon (clay accumulation) is in the B22t subhorizon.

The following list of symbols shows subordinate features of master soil horizons and subhorizons (modified from Birkeland, 1974). These symbols follow the parent material $(1,2,3 \ldots n)$, the master horizon (A, B, $\mathrm{C}, \mathrm{K})$, and the numerical subhorizonation designations. b Buried soil horizon. May be deeply buried and not affected by subsequent surface processes or be at shallow depth and subjected to additional pedogenesis.

ca Accumulations of carbonate of alkaline earths (calcium carbonate in this study) in greater amounts than originally present. Generally occurs in the $\mathrm{C}$ horizon or the lower part of the $\mathrm{B}$ horizon. 
TABLE 1.-Abbreviations used to describe soil characteristics in this report

[The following symbols are used separately or in combination to describe various soil properties such as consistence, structure, and terture. The reader should refer to Appendix 1 of "Soil Taxonomy" (U.S. Department of Agriculture, Soil Conservation Service, 1975) for a description of the terms used to describe soils]

\begin{tabular}{llll}
\hline & TEXTURE $^{2}$ & & WET CONSISTENCE \\
\hline v & very & so & nonsticky \\
g & gravelly & vss & very slightly sticky \\
Sa & sand, sandy & ss & slightly sticky \\
S & silt, silty & s & sticky \\
C & clay, clayey & po & nonplastic \\
L & loam, loamy & vsp & very slightly plastic \\
$(+)$ & high clay content & sp & slightly plastic \\
$(-)$ & low clay content & p & plastic \\
\hline
\end{tabular}

STRUCTURE $^{3}$

\begin{tabular}{|c|c|c|c|c|c|}
\hline & Grade & & lass & & Type \\
\hline$v$ & very & $v$ & very & pl & platy \\
\hline$w$ & weak & $\mathrm{f}$ & fine & $\mathrm{ab}$ & angular blocky \\
\hline m & moderate & $\mathrm{m}$ & medium & sab & $\begin{array}{l}\text { subangular } \\
\text { blocky }\end{array}$ \\
\hline $\mathbf{s}$ & strong & $c$ & coarse & $\mathrm{Sg}$ & $\begin{array}{l}\text { single grain } \\
\text { (structureless) }\end{array}$ \\
\hline & & & & $\mathrm{m}$ & $\begin{array}{l}\text { massive } \\
\text { (structureless) }\end{array}$ \\
\hline
\end{tabular}

\begin{tabular}{llll}
\hline COLOR (MUNSELL NOTATION) & & CALCIUM CARBONATE \\
\hline hue & 5YR (yellowish red) & $\mathrm{n} . \mathrm{d}$. & not detected \\
$5 / \quad$ value (scale of 0-10) & w & weak \\
$/ 4 \quad$ chroma (scale of 0-8) & $\mathrm{m}$ & moderate \\
$\mathrm{d} \quad$ dry (or $\mathrm{m}$, moist) & $\mathrm{s}$ & strong \\
& & stg I first stage & Four stages \\
& & stg II second stage \\
& stg. II third stage \\
\hline
\end{tabular}

\footnotetext{
IExample: vgSaL(-), very gravelly sandy loam minus.

${ }^{2}$ Example: so, po; nonsticky, nonplastic.

${ }^{3}$ Example: mcsab, moderate coarse subangular blocky structure.

4 Example: 5YR5/4d, reddish brown when dry.
}

n Unweathered parent material. Used only for the C horizon.

ox Oxidized parent material. Used only for the C horizon.

s Cambic character of a B horizon.

$t$ Accumulation of illuviated clay in an argillic B horizon.

v Presence of spherically shaped voids (vesicles) in ochric A horizons.

The above symbols may be used in combination, listed in order of sequence of formation (if known). For example, a subhorizon designated Btbca was buried (b) after it became clayey (argillic, $t$ ), but became calcareous (ca) after its burial.

The format of soil descriptions in this report is similar to that used by the SCS. Soil-horizon characteristics such as color, texture, and structure are listed in tabular form to allow easy comparison with other horizons, soils, and laboratory data. The soil characteristics are abbreviated (table 1) and used in combination to describe standard soil properties (U.S. Department of Agriculture, Soil Conservation Service, 1975). Soil carbonate morphology follows the usage of Gile and others (1966). Although semantically incorrect, I refer to soil on a certain geologic unit, whereas it is really formed in the upper part of a unit; a relict soil commonly marks the depositional top of the unit in which it is formed. However, because on indicates position at the top of a unit rather than somewhere within a unit, I prefer its usage over in.

Soil forms when there is a significant interval of landscape stability characterized by relatively low rates of deposition or erosion. Under these conditions, soil formation will continue unless interrupted by erosion or burial. Thus, buried soils and relict (surface) soils mark periods of geomorphic and, in many cases, tectonic stability. With time, soils generally develop stronger structures, accumulate clay, and become thicker (deeper), more consolidated, redder, and possibly more calcareous. These changes, when evaluated as a whole, help to define the degree of soil development and hence the relative age of both a soil and the soil's parent material.

As a matter of convenience for this report, I have given each of the soils exposed in the four trenches an informal name (a letter of the alphabet). The letters $A$, $B, C$, and $K$ are not used because they refer to soil master horizons. Starting with trench 1 , the youngest soil is named "soil D," whereas the two older soils are referred to as "soil E" and "soil F." This nomenclature permits quick reference to soils of each trench and avoids the burden of formal names and implied correlations of soils between trenches.

\section{TRENCH 1}

\section{SETTING}

Trench 1, the most southern of the four, was excavated on a broad piedmont slope at an altitude of $1,920-1,923 \mathrm{~m}(6,300-6,310 \mathrm{ft}), 2.2 \mathrm{~km}$ northeast of the mesa south of Water Canyon (fig. $3 ;$ pl. 2) and about $0.2 \mathrm{~km}$ south of South Canyon. South Canyon is a major local drainage that heads entirely within Oligocene and lower Miocene rhyolitic and andesitic volcanic rocks and coeval Miocene sedimentary rocks of the Popotosa Formation (see Osburn, 1978, for a description of the bedrock geology of this area).

The trench site and adjacent areas of the piedmont are sparsely vegetated by short perennial grasses, yucca, cholla, and juniper. About 30-40 percent of the 
surface is covered by vegetation; the remaining part, where undisturbed, has a thin, weak desert pavement consisting of slightly varnished, pebble-size angular clasts. The area appears to have been used exclusively as rangeland.

No direct temperature or precipitation data are available for this site. However, on the basis of adiabatic lapse rates and regional climatic gradients, I estimate that this site has a mean annual temperature of $10-11^{\circ} \mathrm{C}$ and a mean annual precipitation of about $30 \mathrm{~cm}$; these conditions indicate the site is near the upper limit of the mesic moisture regime. The soil and vegetation associations in this area (SCS, unpub. soil survey mapping, 1978) are typical of a mesic moisture regime (mean annual soil temperature of $8-15^{\circ} \mathrm{C}$, mean annual precipitation of $23-30 \mathrm{~cm}$ ).

The Magdalena Mountains have a pronounced effect on the climate near trenches 1 and 2. These sites are wetter and cooler than those to the north of the Magdalena Mountains (fig. 3 , trench sites 3 and 4). The increased precipitation (rain-shadow effect) along the eastern side of the Magdalenas is indicated by a basinward extension of the boundaries between (1) the grassland and juniper-pine forest, and (2) the calcareous (pedocal) and noncalcareous (pedalfer) soils of Holocene age versus late Pleistocene age. The position of the pedocal-pedalfer boundary is a direct reflection of leaching of calcium carbonate, a water-soluble component, from semiarid soils (see Machette, 1985, for a discussion of factors affecting carbonate accumulation).

\section{GEOLOGIC INVESTIGATIONS}

Trench 1 was excavated across a low fault scarp on a geomorphically stable piedmont surface that is underlain by Holocene and upper Pleistocene alluvium. Fluvial erosion has removed the scarp from the late(?) Holocene flood plain of South Canyon, which is about $400 \mathrm{~m}$ wide in this area. The trench was about $200 \mathrm{~m}$ south of the southern edge of the flood plain (fig. 3; pl. 2). The scarp extends about $1.2 \mathrm{~km}$ north of the flood plain and is formed on alluvium that has soils containing well-developed, thick, argillic B horizons that are very clayey and have strong, coarse, angular-blocky structures and reddish-brown colors (Munsell color notations of $2.5 Y R$ to $5 Y R$ ). These features suggest a pre-late Pleistocene age for the alluvium (late Pleistocene is here considered to range from 10-125 ka ago).

South of South Canyon, the fault forms a single, low, continuous scarp that extends $1.6 \mathrm{~km}$ across the late Pleistocene-Holocene piedmont. South of the piedmont (south part of sec. 28, T. 3 S., R. 2 W., pl. 2), the scarp rises onto the deeply dissected middle Pleistocene alluvial fan of Sixmile Canyon.
The faulted alluvium at trench 1 is much younger than the alluvium just to the north of South Canyon. At trench 1 , the alluvium forms a broad, slightly undulating surface that retains some of its depositional bar-and-swale morphology. This alluvium consists of moderately to well sorted, poorly bedded sandy gravel containing local cutand-fill channels, many of which are filled with openwork pebble layers. These layers commonly contain mechanically infiltrated clay (see discussion of Walker and others, 1978) that is relatively abundant below the solum and is especially well developed as pebble coatings and thin, discontinuous clay laminae (U.S. Department of Agriculture, Soil Conservation Service, 1975).

Trench 1 extended about $10 \mathrm{~m}$ west (upslope) of the main fault (fig. 5, pl. 1A) so as to include the uneroded original surface of the faulted deposit. Because no datable materials were found in this (or any of the other trenches), the only practical method for estimating ages was to assess the development of soils formed on faulted deposits. These age assessments were made either by comparing a soil's development to that of another of known age or by estimating rates of soil development based on soil data from the region and applying these rates to soils at the trench sites. For example, at trench 1 , the soil (E) on the youngest faulted deposit (pl. 1A, unit 3, alluvium) contains a thin, weak argillic $B$ horizon and an oxidized $\mathrm{C}$ horizon (table 3 , profile T1-2); these features suggest a degree of development similar to middle Holocene soils from the Las Cruces area of southern New Mexico.

The clay content $(<2-\mu \mathrm{m}$ fraction) of the $\mathrm{B}$ horizon of a soil is one parameter that is commonly used for comparison of development; however, the overall texture of a soil must be considered in such comparisons. Clay is commonly reported on the basis of its content in the less-than-2-mm fraction of the soil. For example, if a Bt horizon has 10 percent clay in the less-than-2-mm fraction, and if this fraction is 10 percent of the whole soil (90 percent gravel), then the soil has only 1 percent total clay on a whole-soil basis. A finely textured soil containing 10 percent clay in the $B$ horizon can easily have several times as much clay as the same-age soil on coarse-textured material.

Clay data in this report are calculated on the basis of whole soil. Clay data for the Bt horizons of three Holocene soils from southern New Mexico (table 2) are compared to clay data for soil $\mathrm{E}$ at trench 1 . The three soils from southern New Mexico have formed since middle Holocene time and are thought to be no older than about 6,400 years (Gile, 1975, 1977). All four soils contain incipient to weak argillic B horizons, whereas upper Pleistocene soils in both regions are characterized by thin but moderately well developed argillic $B$ horizons. 
The argillic B horizon of soil $\mathrm{E}$ has gained 9 percent clay (table 2, column A, <2-mm fraction); that is, the $B$ horizon contains 16 percent clay versus 7 percent clay in the $\mathrm{C}$ horizon (parent material). However, of the four Holocene soils mentioned previously, soil $\mathrm{E}$ has gained the least weight of clay (table 2, column C). Soil E has about one-half the weight increase of clay as its gravelly analog to the south (Pinaleno series, table 2). This disparity is best explained by slower rates of dust deposition in the southern part of the La Jencia basin than in southern New Mexico. To the west of trench 1, the Magdalena Mountains form an effective barrier to low-altitude (that is, less than 3-km altitude) transport of dust. The apparent stronger development of midHolocene B horizons in southern New Mexico is even more pronounced on fine-grained material such as the Sonoita series (pedon 60-8, table 2), which has the most clay available for translocation and thus has the most weight increase of clay $\left(3.4 \mathrm{~g} / \mathrm{cm}^{2}\right.$, grams per square centimeter) of the four B horizons being compared.

Soils on the youngest (late Holocene) alluvial deposits adjacent to trench 1 are noncalcareous, which suggests that the rainfall in the late Holocene has been sufficient to prevent calcium carbonate from accumulating in the soil. Soil E on the upthrown fault block at trench 1 (profile T1-2, table 3 ) contains very weak carbonate (stage I of Gile and others, 1965) that is preserved in pits and hollows on cobbles and boulders. The carbonate is probably a remnant of a once more extensive, although weakly developed, calcic horizon that formed under arid conditions during middle(?) Holocene time. Since that time, the carbonate has been almost completely removed by leaching. Both Gile (1975) and Haynes (1968) suggested that much of the coarse-grained Holocene alluvium in the Southwest was deposited during dry climatic episodes. Gile (1975) correlated his oldest unit of "Organ alluvium" (Organ I alluvium, mid-Holocene) with the Altithermal, a correlation that is supported by ${ }^{14} \mathrm{C}$ dates of $4.5-6.4 \mathrm{ka}$. The faulted alluvium (unit 3) at trench 1 is a part of a widespread, major depositional unit along the eastern flank of the Magdalena Mountains. On the basis of the distribution of this alluvium

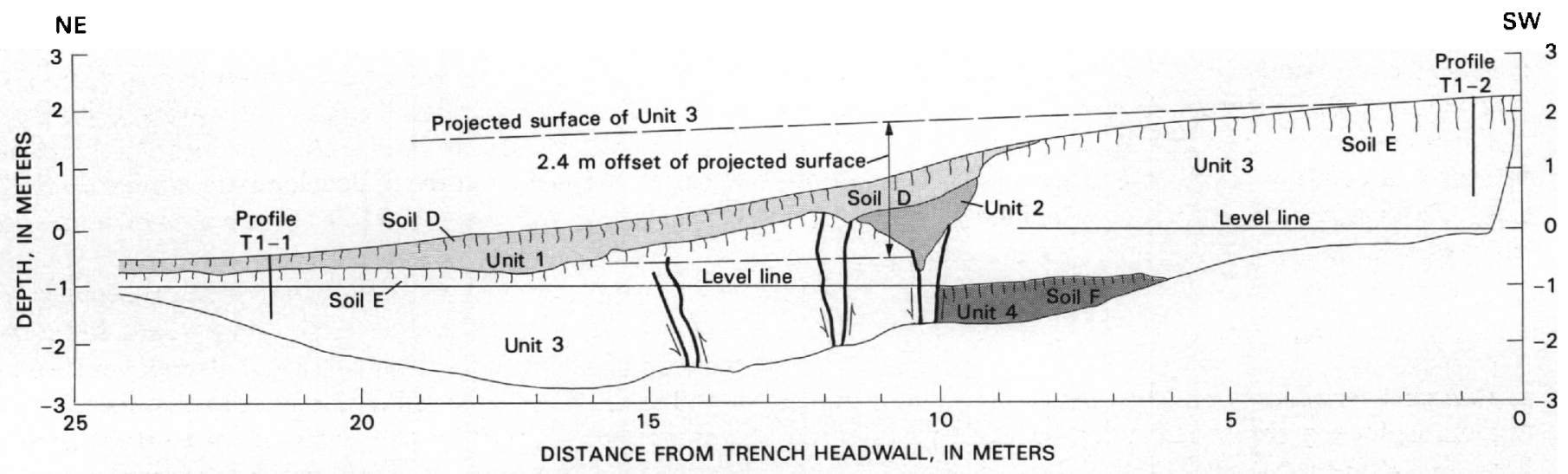

FIGURE 5.-Simplified sketch map of major geologic and soil units in trench 1. See plate 1A for detailed section; south wall of trench was mapped. Horizontal and vertical distances measured from upper end of trench and highest level line, respectively. Direction of movement along faults (heavy lines) shown by arrows. Units 1-4 are described in the section on "Description of Soil Parent Materials" on plate 1. Soils D, E, and F are described in the section on "Description of Soil Horizons in Trench 1."

TABLE 2.-Clay contents of argillic B horizons in four Holocene soils of New Mexico

[A, percent clay $(<2 \mu \mathrm{m})$ in the $<2$-mm size fraction; B, percent clay in the whole-soil fraction; and C, weight (g) of clay in a $1-\mathrm{cm}^{2}$ column through soil (whole-soil fraction). Calculated from data of Gile and Grossman (1979) and this report. Gain, net increase of clay in Bt horizon]

\begin{tabular}{|c|c|c|c|c|c|c|c|c|c|}
\hline Soil series (Pedon) & \multicolumn{3}{|c|}{$\begin{array}{c}\text { A } \\
\text { Percent clay }\end{array}$} & \multicolumn{3}{|c|}{$\begin{array}{c}\text { B } \\
\text { Percent clay }\end{array}$} & \multicolumn{3}{|c|}{ Weight of clay } \\
\hline $\begin{array}{l}\text { Pinaleno }(66-16)--- \\
\text { Pinaleno }(67-4)---- \\
\text { Sonoita }(60-8)----- \\
\text { Sedillo, (soil E, } \\
\text { profile T1-2). }\end{array}$ & $\begin{array}{l}12 \\
15 \\
12\end{array}$ & $\begin{array}{l}7 \\
8 \\
6\end{array}$ & $\begin{array}{l}5 \\
7 \\
6\end{array}$ & $\begin{array}{r}5.2 \\
5.4 \\
10.4\end{array}$ & $\begin{array}{l}2.8 \\
2.7 \\
4.7\end{array}$ & $\begin{array}{l}2.4 \\
2.7 \\
5.7\end{array}$ & $\begin{array}{r}7.8 \\
6.8 \\
10.4\end{array}$ & $\begin{array}{l}5.6 \\
4.2 \\
7.0\end{array}$ & $\begin{array}{l}2.2 \\
2.6 \\
3.4\end{array}$ \\
\hline
\end{tabular}


TABLE 3.-Laboratory data and field description for soil E, profile T1-2, trench 1, La Jencia fault

LABORATORY DATA

[Grain-gize analyses of noncalcareous soil fraction in percent; vc, very coarse; $c$, coarse; m, medium; $f$, fine; vf, very fine; $\mu \mathrm{m}$, micrometers; <, less than; >, greater than. Laboratory analyses by Donald Cheney, U.S. Geological Survey]

\begin{tabular}{|c|c|c|c|c|c|c|c|c|c|c|c|c|c|c|c|c|}
\hline \multirow{2}{*}{$\begin{array}{l}\text { Grain-size } \\
\text { Grain-size }\end{array}$} & \multicolumn{2}{|c|}{ classes----D-- } & \multicolumn{3}{|c|}{$<2-\mathrm{mm}$ fraction } & \multicolumn{5}{|c|}{ Sand $(\mathrm{mm})$} & \multicolumn{2}{|c|}{ Silt $(\mu \mathrm{m})$} & \multicolumn{2}{|c|}{ Clay $(\mu \mathrm{m})$} & \multicolumn{2}{|c|}{ Whole sample } \\
\hline & categorie & -------- & Sand & Silt & Clay & vo & c & $\mathrm{m}$ & $\mathrm{f}$ & $\mathrm{vf}$ & c & $f$ & c & $\mathrm{f}$ & & \\
\hline Grain sizes & $(\mathrm{mm})----$ & $\cdots---\cdots$ & $\overline{\left(2.0^{-}\right.}$ & $\left(0.05^{-}\right.$ & $(<0.002)$ & $(2-1)$ & $(1-0.5)$ & $10.5^{-}$ & $(0.25-$ & $(0.1-$ & $(50-20)$ & $(20-2)$ & $(2-0.5)$ & $(<0.5)$ & $(<2 \mathrm{~mm})$ & $(>2 \mathrm{~mm})$ \\
\hline $\begin{array}{l}\text { Sample } \\
\text { No. }\end{array}$ & $\begin{array}{l}\text { Depth } \\
(\mathrm{cm})\end{array}$ & $\begin{array}{l}\text { Horizon or } \\
\text { subhorizon }\end{array}$ & $0.05)$ & $0.002)$ & & & & $0.25)$ & $0.1)$ & $0.05)$ & & & & & & \\
\hline T1-2a--- & $0-9-\cdots$ & $3 A-------$ & 56.3 & 33.0 & 10.7 & 14.2 & 15.8 & 12.0 & 8.0 & 6.3 & 28.8 & 10.5 & 3.1 & 7.6 & 48.1 & 51.9 \\
\hline $\mathrm{T} 1-2 \mathrm{~b}^{---}$ & $9-18---$ & $3 \mathrm{~B} 22 \mathrm{t} \ldots$ & 51.7 & 32.7 & 15.6 & 12.0 & 12.7 & 11.5 & 9.2 & 6. & 19.3 & 13.4 & 4.0 & 11.6 & 28 & 71.9 \\
\hline $\mathrm{T} 1-2 \mathrm{c}^{---}$ & $18-27---$ & $3 B 23 t---$ & 56.9 & 29.9 & 13.2 & 13.4 & 12.9 & 12.3 & 11.4 & 6.9 & 16.9 & 13.0 & 3.6 & 9.6 & 18.1 & 81.9 \\
\hline$T 1-2 d^{---}$ & $27-52---$ & $3 \mathrm{Cn}-\cdots$ & 77.4 & 15.6 & 7.0 & 21.0 & 10.9 & 19.5 & 13.4 & 4.4 & 11.6 & 4.0 & 2.8 & 4.2 & 20.7 & 79.3 \\
\hline $\mathrm{T} 1-2 \mathrm{e}^{---}$ & $52-145--$ & $3 \operatorname{Cox}-\cdots$ & 89.0 & 4.4 & 6.6 & 44.7 & 26.1 & 12.3 & 4.4 & 1.5 & 2.0 & 2.4 & 2.0 & 4.6 & 23.1 & 76.9 \\
\hline
\end{tabular}

[Grain-eize analyses of gravel fraction, organic-matter content, and calcium carbonate content in percent; bulk density in $\mathrm{g}^{\prime} \mathrm{cm}^{3}$; f, fine; m, medium; c, coarse; <, less than; >, greater than; n.d., not determined. Laboratory analyses by Donald Cheney, U.S. Geological Survey]

\begin{tabular}{|c|c|c|c|c|c|c|c|c|c|c|}
\hline \multirow[b]{2}{*}{$\begin{array}{l}\text { Grain-size categories } \\
\text { Grain sizes (mm)----- } \\
\text { Sample } \\
\quad \text { No. }\end{array}$} & \multicolumn{3}{|c|}{ Gravel $(>2 \mathrm{~mm})$} & \multirow[b]{2}{*}{$\begin{array}{l}\text { Organic } \\
\text { matter }\end{array}$} & \multirow[b]{2}{*}{${ }_{\mathrm{pH}}{ }$} & \multicolumn{2}{|c|}{ Bulk density } & \multicolumn{2}{|c|}{$\mathrm{CaCO}_{3}$} & \multirow[b]{2}{*}{ Texture } \\
\hline & $\frac{f}{(2-19)}$ & $\frac{m}{(19-76)}$ & $\frac{c}{(>76)}$ & & & $<2 \mathrm{~mm}$ & $\begin{array}{l}\text { Whole } \\
\text { sample }\end{array}$ & $<2 \mathrm{~mm}$ & $\begin{array}{l}\text { Whole } \\
\text { sample }\end{array}$ & \\
\hline 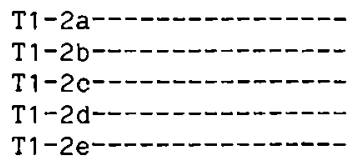 & $\begin{array}{l}29.5 \\
22.4 \\
21.9 \\
34.8 \\
46.9\end{array}$ & $\begin{array}{l}22.4 \\
49.5 \\
60.0 \\
44.5 \\
30.0\end{array}$ & $\begin{array}{l}0 \\
0 \\
0 \\
0 \\
0\end{array}$ & $\begin{array}{l}\text { n.d. } \\
\text { n.d. } \\
\text { n.d. } \\
\text { n.d. } \\
\text { n.d. }\end{array}$ & $\begin{array}{l}7.2 \\
6.5 \\
6.7 \\
6.9 \\
7.2\end{array}$ & $\begin{array}{l}\text { n.d. } \\
\text { n.d. } \\
\text { n.d. } \\
\text { n.d. } \\
\text { n.d. }\end{array}$ & $\begin{array}{l}\text { n.d. } \\
\text { n.d. } \\
\text { n.d. } \\
\text { n.d. } \\
\text { n.d. }\end{array}$ & $\begin{array}{l}0.5 \\
.3 \\
.5 \\
.4 \\
.4\end{array}$ & $\begin{array}{r}0.2 \\
.1 \\
* .1 \\
* .3 \\
.3\end{array}$ & $\begin{array}{l}\text { Very gravelly, sandy loam. } \\
\text { Very gravelly, sandy loam plus to loam. } \\
\text { Very gravelly, sandy loam. } \\
\text { Very gravelly, loamy sand to sandy loam. } \\
\text { Very gravelly, sand plus. }\end{array}$ \\
\hline
\end{tabular}

${ }_{*}^{*}$ Values of $\mathrm{pH}$ measured in paste consisting of 1 part soil and 2.5 parts water.

*Estimated value. 
FIELD DESCRIPTION

[n.d., no data; table 1 for abbrevations]

SOIL PROFILE: T1-2, sOII E, trench 1.

DESCRIBED BY: M. N. Machette.

DATE: December 14, 1978.

PARENT MATERIAL: Coarse-grairied alluvium (unit 3 ).

AGE: Middle to early Holocene.

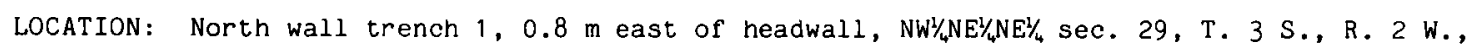
Magdalena 15-minute quadrangle.

GEOGRAPHICAL LANDSCAPE: Relict surface of broad piedmont slope.

SOIL DEVELOPMENT: SOII E, weak.

ELEVATION: $1,923 \mathrm{~m}$. SLOPE: $2 \frac{212^{\circ}}{}$ ASPECT: N. $60^{\circ} \mathrm{E}$. EROSION: Slight.

CLIMATE: Semiarid: estimated mean annual temperature, $10-11{ }^{\circ} \mathrm{C}$; mean-annual precipitation, $30 \mathrm{~cm}$.

VEGETATION: Short grasses, yucca, cholla, and sparse junipers.

REMARKS: $\mathrm{CaCO}_{3}$ development inconsistent with distribution. Some rare $\mathrm{CaCO}_{3}$ patches as thick as $0.5 \mathrm{~mm}$ on pits of some gravel clasts.

\begin{tabular}{|c|c|c|c|c|c|c|c|c|c|}
\hline $\begin{array}{l}\text { Sample } \\
\text { No. }\end{array}$ & $\begin{array}{l}\text { Depth } \\
(\mathrm{cm})\end{array}$ & Hor izon & Color & Texture & Structure & $\begin{array}{l}\text { Consist- } \\
\text { ence }\end{array}$ & $\begin{array}{l}\text { Clay } \\
\text { films }\end{array}$ & $\mathrm{CaCO}_{3}$ & Comments \\
\hline$T 1-2 a---$ & $0-9-\cdots$ & $3 A \cdots \cdots$ & $10 \underline{Y R} 4.5 / 5 d-$ & vgSaL---- & $\begin{array}{l}\text { vwmpl } \\
\text { to sg. }\end{array}$ & ss, & n.d...- & None----- & $\begin{array}{l}1-3 \mathrm{~cm} \text { diameter clasts; two-thirds of } \\
\text { surface has desert pavement. }\end{array}$ \\
\hline $\mathrm{T} 1-2 \mathrm{~b}---$ & $9-18--$ & $3 B 22 t---$ & $7.5 \mathrm{YR} 4.5 / 5 \mathrm{~d}$ & $\begin{array}{l}\text { vgSaL }(+) \\
\text { to vgL. }\end{array}$ & $\begin{array}{l}\text { vwfsab } \\
\text { to sg. }\end{array}$ & ss, & n.d. .-- & None. & \\
\hline $\mathrm{Tl} 1-2 \mathrm{c}^{---}$ & $18-27-$ & $3 B 23 t---$ & $10 \underline{Y R} 5 / 3.5 d-$ & vgSaL---- & $\begin{array}{l}\text { vwfsab } \\
\text { to sg. }\end{array}$ & ss, & n.d. - - - & None. & \\
\hline$T 1-2 d---$ & $27-52-$ & $3 \mathrm{Cn}-----$ & $\begin{array}{l}10 Y \text { YR } 5 / 2 \mathrm{~d} \text { to } \\
10 \underline{Y} 5 / 4 \mathrm{~d} .\end{array}$ & $\begin{array}{c}\text { vgLSa }(+) \\
\text { to vg } \\
\operatorname{SaL}(-)\end{array}$ & sg----- & $\begin{array}{l}\text { vss, } \\
\text { po. }\end{array}$ & n.d.--- & $\begin{array}{l}\text { vW stg I, } \\
\text { patchy. }\end{array}$ & Clay coats (5YR $4.5 / 5 d$ ) on few clasts. \\
\hline T1-2e--- & $52-145$ & $3 \operatorname{Cox}----$ & $\begin{array}{l}10 Y R 5 / 2 d \text { to } \\
10 \underline{Y R} 5 / 4 d .\end{array}$ & $\operatorname{vgSa}(+)--$ & sg----- & so, po. & n.d.--- & $\begin{array}{l}\text { m stg } I \\
\text { patchy. }\end{array}$ & Clay coats (5YR $4.5 / 5 d)$ on most clasts. \\
\hline No sample & $145+--$ & $3 \mathrm{Clox}---$ & n.d. - - - - & $\operatorname{vgSa}(+)--$ & sg----- & so, & n.d. - - & n.d. & \\
\hline
\end{tabular}


and the degree of development of its relict soil, I consider alluvial unit 3 to be equivalent to Gile's "Organ I alluvium" of southern New Mexico.

At trench 1, the surface of unit 3 is displaced about $2.4 \mathrm{~m}$ (fig. 5, pl. 1A) across a narrow zone of faults. The main fault (one of three in trench 1 ), which is about $10 \mathrm{~m}$ downslope from the western end of the trench, offsets unit 3 about $1.4 \mathrm{~m}$; an additional $1 \mathrm{~m}$ of displacement was accumulated by drag and offset along two minor faults. Movement along the main fault has disturbed the alluvium in a 25- to $45-\mathrm{cm}$-wide zone (pl. $1 \mathrm{~A}, 3 \mathrm{Cn}$ horizon); this zone is overlain by two younger deposits of undisturbed colluvium, mapped as the $\mathrm{A}+\mathrm{B}$ and $2 \mathrm{Cn}$ horizons. The $2 \mathrm{Cn}$ horizon is coarse gravelly colluvium derived from gravitational slumping and raveling of the free face of the fault scarp (gravity and debris-controlled processes of Wallace, 1977). The upper colluvium (unit $1, \mathrm{~A}+\mathrm{B}$ horizon, pl. 1A) is finer grained than the lower colluvium and contains abundant angular, pebble-size clasts that form desert pavement on the surface of the upthrown block. The upper colluvium, a combination of materials derived from both progressive degradation of the scarp and erosion of the upthrown surface, is interpreted as having been deposited largely by washcontrolled scarp-degradation processes (Wallace, 1977). Projection of the original surface of unit 3 , shown by a dashed line on plate $1 \mathrm{~A}$, indicates that about $25 \mathrm{~cm}$ has been eroded from the upthrown block near the crest of the scarp.

The time of faulting at trench 1 can be bracketed using the following arguments: (1) the age of relict soil $\mathrm{E}$ on the upthrown block is close to the age of the material in which it formed (unit 3); (2) the development of soil $\mathrm{D}$ on colluvium of the downdropped block indicates the time since the colluvial wedge was deposited in response to faulting; and (3) the development of soil $E$ on the downdropped block indicates the time between deposition of the youngest faulted unit (3) and its subsequent, postfaulting burial by scarp colluvium (units 1 and 2). At trench 1, evidence for arguments 1 and 3 are the most conclusive, whereas evidence for argument 2 is hard to interpret because the scarp colluvium has been accumulating since faulting. Where the scarp colluvium and superposed soil are young, the soils are commonly attenuated. Thus, the following discussion deals with arguments 1 and 3 for interpreting the age of faulting at trench 1 .

Buried-soil E (lower part of profile T1-1, table 4) formed from the time deposition of unit 3 ceased until it was buried by colluvium (unit 2 and then unit 1), sometime after faulting. Burial was earliest and fastest near the base of the scarp and latest and slowest farther to the east, away from the scarp. Although weakly developed, buried soil $\mathrm{E}$ is strongest in the eastern $6 \mathrm{~m}$ of the trench; to the west, toward the main fault (and scarp), it is progressively less developed.

Buried-soil $E$ consists of a thin, slightly calcareous, nonargillic $\mathrm{B}$ horizon (3Bca) and a weakly calcareous $\mathrm{C}$ horizon (3Cca) having stage I carbonate. The carbonate forms discontinuous to continuous coatings only $0.5 \mathrm{~mm}$ thick on the bases of some of the clasts, whereas the soil matrix $(<2-\mathrm{mm}$ fraction) is generally noncalcareous. The carbonate has morphology similar to that of soils on alluvium of several thousand years age at arid sites in southern New Mexico (Gile, 1975, 1977), but it is less abundant. Based on the presence of weak carbonate (stage I, 3Bca and 3Cca horizons) in the buried soil and even weaker development of the calcic horizons toward the fault, it seems likely that unit 3 was faulted soon after deposition, an interval of perhaps as little as several hundred years to as much as a thousand years.

Relict-soil D, which is on scarp colluvium (profile T1-1, upper part, table 4), has an $\mathrm{A} / \mathrm{B} / \mathrm{Cn}$ profile that is poorly developed in comparison to relict-soil $E$ on the upthrown fault block (profile Tl-2, table 3). Although the $B$ horizon of soil $D$ is not clayey enough to be an argillic horizon, it qualifies as a position $B$ (that is, the horizon between an A horizon and a Cca horizon) with weak structural development. It is not reddened enough to qualify as a cambic B horizon. Soil D is on gravelly sandy loam that contains 9-10 percent clay throughout the profile (table 4). The weak development of this soil probably results from two factors: a lack of time and an unstable geographic setting. This soil has formed since middle Holocene time on an accumulating wedge of scarp colluvium. As the slope of the scarp declined, slower deposition of colluvium allowed $\mathrm{A}$ and $\mathrm{B}$ horizons to develop. However, these horizons are spread out in a thicker unit than they normally would be at a stable site. Although the age of an attenuated soil profile such as this is difficult to interpret, its weak development and lack of calcium carbonate suggest only thousands of years of formation.

When did the faulting occur? As shown earlier, the clay content in the B horizon of relict-soil E (profile T1-2, column $\mathrm{C}$, table 2) suggests a middle or early(?) Holocene age based on comparison with dated Holocene soils in southern New Mexico. This soil also contains calcium carbonate that must have accumulated during a former dry climate such as the Altithermal, which persisted from about 4 or $5 \mathrm{ka}$ ago to $7 \mathrm{ka}$ ago (Antevs, 1955; Mehringer, 1967). Since the end of the Altithermal, the pedocal-pedalfer boundary has shifted basinward (east and lower) of trench-site 1 in reponse to increased soilmoisture conditions, thereby preventing calcium carbonate from further accumulating in soils $\mathrm{D}$ or $\mathrm{E}$.

The alluvial deposits exposed in trench 1 form a broad piedmont slope that was deposited by laterally shifting 
streams flowing from South Canyon. Faulting during deposition resulted in stream incision on the upthrown block, thereby isolating much of the piedmont surface from further deposition. Once the piedmont became geomorphically stable, soils started to form on the underlying alluvium (unit 3 ).

On the basis of these arguments and the soils data presented here, the faulting probably occurred about 1,000 years before the end of the Altithermal, about $5 \mathrm{ka}$ ago. Two units of colluvium, derived from the fault scarp, buried a weak, incipient phase of soil $\mathrm{E}$. The rate of deposition of colluvium probably declined with time (Nash, 1980), so that all of unit 2 and most of unit 1 accumulated in a few thousand years (late-middle Holocene). Deposition of colluvium at trench 1 continues today, albeit at such a slow rate that it does not impede soil formation (see the section on "Scarp Morphology as an Indicator of Age" for a discussion of how rates of scarp degradation may change with time).

\section{SUMMARY}

The following conclusions can be drawn from the geologic investigations at trench 1 :

1. On the basis of geologic and pedologic evidence and climatic interpretations, faulting occurred about $5 \mathrm{ka}$ ago, near the end of the Altithermal.

2. Faulting caused entrenchment of the streams of South Canyon, thereby isolating the majority of the upthrown deposits from additional alluviation and allowing the processes of soil formation to act upon the newly isolated alluvial surface.

3. The buried-soil $\mathrm{E}$ (middle Holocene) that is preserved in the downdropped block formed in a drier climate (that is, the Altithermal) than that of adjacent late Holocene soils. The buried soil is a weakly developed pedocal and contains thin, weakly calcareous B and $\mathrm{C}$ horizons; it probably formed during a short interval (less than 1,000 years) prior to faulting. Soils formed since faulting are noncalcareous, weakly developed pedalfers without argillic $\mathrm{B}$ horizons, whereas the relict-soil $\mathrm{E}$ on the upthrown block has a weak argillic $\mathrm{B}$ horizon.

4. A narrow zone of faults, which have produced uniform scarps as much as $3 \mathrm{~m}$ in height, cuts deposits that range in age from several hundred thousand years (north of the trench) to about 6 ka (unit 3 at the trench). The prefault alluvial surface of unit 3 at trench 1 is offset $2.4 \mathrm{~m}$, the product of one episode of movement along three strands of the fault. No evidence of prior movements are recorded in either the trench or in the adjacent, older alluvial deposits of South Canyon.

\section{TRENGH 2}

\section{SETTING}

Trench 2 was near the middle of a moderately sloping alluvial fan that emanates from Shakespeare Canyon, near the south end of the central part of the La Jencia fault, about $1 \mathrm{~km}$ north of Water Canyon (fig. 3). This fan is typical of those deposited at the mouths of small canyons; they range from $0.5-1 \mathrm{~km}^{2}$ (square kilometer) in area. The large fans at the mouths of Ellis and Jordan Canyons to the north (fig. 3) are as much as $5 \mathrm{~km}^{2}$ in area. Water Canyon, which is the largest drainage (45 $\mathrm{km}^{2}$ ) on the eastern side of the Magdalena Mountains, has one of the largest fans in La Jencia basin, and it dominates the southern part of the basin.

The site is at $2,036-\mathrm{m}(6,680-\mathrm{ft})$ altitude (pl. 2) near the lower boundary of the pinon pine and juniper forest. Trees and small bushes cover 15-20 percent of the land surface; the remainder of the surface is covered by a moderately dense mixture of short grasses. Sparse yucca and cholla are common where the land has been disturbed by overgrazing.

Because this site is closer to the Magdalena Mountains than the other three sites, its microclimate is greatly influenced by the local topography. Mean-annual temperature and precipitation at the site are estimated to be about $9-10^{\circ} \mathrm{C}$ and $35 \mathrm{~cm}$ on the basis of regional climatic trends, vegetation-soil associations, and adiabatic lapse rate. Of the four trench sites, this one receives the most precipitation and has the lowest temperature.

The alluvial fan at trench 2 was deposited by streams discharging from Shakespeare Canyon (fig. 3). This canyon has a small drainage area $\left(1 \mathrm{~km}^{2}\right)$ that is entirely in Precambrian schist, granite, and gneiss. At the present time, most of the alluvial-fan surface is isolated from water discharging from Shakespeare Canyon owing to stream incision. The fan surface is smooth and largely undissected except for several localities where small ephemeral streams, heading entirely upon the alluvialfan surface, have cut into the fault scarp. About 75 percent of the fan surface is geomorphically stable; the remainder is incised by a few 5- to 10-m-deep channels and more numerous small arroyos.

The La Jencia fault cuts alluvium of the Shakespeare Canyon fan and adjacent deposits along a north northwest/south-southeast trend. The scarp ranges from less than $2 \mathrm{~m}$ in height, on the south, to 4-3/4 m near trench 2 in the central part of the fan. Several hundred meters north of trench 2, the scarp is eroded, and the fault is concealed by Holocene alluvium. The fault forms a scarp that is dissected in places as far north as the small hill due west of the S. Strozzi Ranch. 
TABLE 4.-Laboratory data and field description for soils $D$ and $E$, profile T1-1, trench 1, La Jencia fault LABORATORY DATA

[Grain-size analyses of noncalcareous soil fraction in percent; vc, very coarse; c, coarse; m, medium; f, fine; vf, very fine; $\mu \mathrm{m}$, micrometers; <, less than; > greater than. Laboratory analysee by Donald Cheney, U.S. Geological Survey]

\begin{tabular}{|c|c|c|c|c|c|c|c|c|c|c|c|c|c|c|c|c|}
\hline \multirow{2}{*}{\multicolumn{3}{|c|}{$\begin{array}{l}\text { Grain-size classes-- } \\
\text { Grain-size categories- }\end{array}$}} & \multicolumn{3}{|c|}{$<2-\mathrm{mm}$ fraction } & \multicolumn{5}{|c|}{ Sand $(\mathrm{mm})$} & \multicolumn{2}{|c|}{ Silt $(\mu \mathrm{m})$} & \multicolumn{2}{|c|}{ Clay $(\mu \mathrm{m})$} & \multicolumn{2}{|c|}{ Whole sample } \\
\hline & & & Sand & Silt & Clay & ve & c & $\mathrm{m}$ & $\mathrm{f}$ & vf & c & $\mathbf{f}$ & $\mathrm{c}$ & $\mathrm{f}$ & & \\
\hline Grain sizes & $\mathrm{s}(\mathrm{mm})-\cdots$ & --- -- - & $\left(2.0^{-}\right.$ & $(0.05-$ & $(<0.002)$ & $(2-1)$ & $(1-0.5)$ & $\left(0.5^{-}\right.$ & $(0.25-$ & $(0.1-$ & $(50-20)$ & $(20-2)$ & $(2-0.5)$ & $(<0.5)$ & $(<2 \mathrm{~mm})$ & $(>2 \mathrm{~mm}$ \\
\hline $\begin{array}{c}\text { Sample } \\
\text { No. }\end{array}$ & $\begin{array}{c}\text { Depth } \\
(\mathrm{cm})\end{array}$ & $\begin{array}{l}\text { Horizon or } \\
\text { subhorizon }\end{array}$ & $0.05)$ & $0.002)$ & & & & $0.25)$ & $0.1)$ & $0.05)$ & & & & & & \\
\hline T1-1a--- & $0-12---$ & $A-\ldots$ & 55.0 & 35.2 & 9.8 & 10.2 & 13.5 & 12.9 & 11.6 & 6.8 & 20.8 & 14.4 & 2.6 & 7.2 & 50.3 & 49.7 \\
\hline $\mathrm{T} 1-1 \mathrm{~b}---$ & $12-31---$ & B------- & 59.3 & 30.4 & 10.3 & 18.5 & 14.3 & 10.4 & 9.6 & 6.7 & 15.7 & 14.7 & 2.6 & 7.7 & 45.4 & 54.6 \\
\hline T1-1c--- & $31-50---$ & $\mathrm{Cn}^{--------}$ & 59.0 & 31.8 & 9.2 & 12.3 & 13.6 & 13.4 & 12.2 & 7.5 & 19.0 & 12.8 & 3.0 & 6.2 & 51.9 & 48.1 \\
\hline$T 1-1 d-\cdots$ & $50-64---$ & 3Bcab----- & 69.2 & 22.4 & 8.4 & 26.8 & 16.5 & 11.5 & 9.8 & 4.6 & 11.8 & 10.6 & 2.9 & 5.5 & 34.4 & 65.6 \\
\hline T1-1e--- & 64-90--- & 3Ccab---- & 84.7 & 9.5 & 5.8 & 19.7 & 24.8 & 24.9 & 12.6 & 7.4 & 4.7 & 4.8 & 2.2 & 3.6 & 18.3 & 81.7 \\
\hline T1-1f--- & $90-110+-$ & $3 \mathrm{Cnb}---$ & 85.2 & 7.5 & 7.3 & 23.6 & 22.3 & 22.9 & 14.2 & 2.2 & 6.5 & 3.2 & 1.9 & 5.4 & 28.6 & 71.4 \\
\hline
\end{tabular}

[Grain-size analyses of gravel fraction, organic-matter content, and calcium carbonate content in percent; bulk density in g/cm³ if fine; m, medium; c, coarse; <, less than; >, greater than; n.d., not determined; Do., ditto. Laboratory andyses by Donald Cheney, U.S. Geological Survey]

\begin{tabular}{|c|c|c|c|c|c|c|c|c|c|c|}
\hline \multirow[b]{2}{*}{$\begin{array}{l}\text { Grain-size categories } \\
\text { Grain sizes (mm)---- } \\
\text { Sample } \\
\quad \text { No. }\end{array}$} & \multicolumn{3}{|c|}{ Gravel (>2 mm) } & \multirow[b]{2}{*}{$\begin{array}{l}\text { Organic } \\
\text { matter }\end{array}$} & \multirow[b]{2}{*}{${ }^{ \pm} \mathrm{pH}$} & \multicolumn{2}{|c|}{ Bulk density } & \multicolumn{2}{|c|}{$\mathrm{CaCO}_{3}$} & \multirow[b]{2}{*}{ Texture } \\
\hline & $\frac{f}{(2-19)}$ & $\frac{m}{(19-76)}$ & $\frac{c}{(>76)}$ & & & $<2 \mathrm{~mm}$ & $\begin{array}{l}\text { Whole } \\
\text { sample }\end{array}$ & $<2 \mathrm{~mm}$ & $\begin{array}{l}\text { Whole } \\
\text { sample }\end{array}$ & \\
\hline 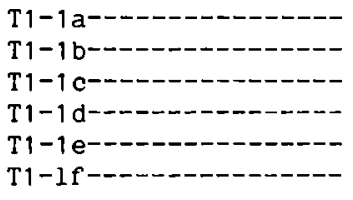 & $\begin{array}{r}31.2 \\
38.6 \\
38.9 \\
33.6 \\
6.7 \\
37.4\end{array}$ & $\begin{array}{r}18.5 \\
16.0 \\
9.2 \\
32.0 \\
54.8 \\
34.0\end{array}$ & $\begin{array}{r}0.0 \\
.0 \\
.0 \\
.0 \\
8.2 \\
.0\end{array}$ & $\begin{array}{l}\text { n.d. } \\
\text { n.d. } \\
\text { n.d. } \\
\text { n.d. } \\
\text { n.d. } \\
\text { n.d. }\end{array}$ & $\begin{array}{l}6.6 \\
6.9 \\
7.1 \\
6.9 \\
7.5 \\
7.5\end{array}$ & $\begin{array}{l}\text { n.d. } \\
\text { n.d. } \\
\text { n.d. } \\
\text { n.d. } \\
\text { n.d. } \\
\text { n.d. }\end{array}$ & $\begin{array}{l}\text { n.d. } \\
\text { n.d. } \\
\text { n.d. } \\
\text { n.d. } \\
\text { n.d. } \\
\text { n.d. }\end{array}$ & $\begin{array}{r}0.5 \\
.3 \\
.5 \\
.3 \\
.5 \\
.4\end{array}$ & $\begin{array}{r}0.2 \\
.1 \\
.2 \\
.1 \\
.1 \\
.1\end{array}$ & $\begin{array}{l}\text { Gravelly, sandy loam. } \\
\text { Very gravelly, sandy loam. } \\
\text { Gravelly, sandy loam. } \\
\text { Very gravelly, sandy loam. } \\
\text { Very gravelly, loamy sand minus. } \\
\text { Do. }\end{array}$ \\
\hline
\end{tabular}

IValues of $\mathrm{pH}$ measured in paste consisting of 1 part soil and 2.5 parts water. 
FIELD DESCRIPTION

[n.d., no data; Do., ditto; table 1 for abbrevations]

SOIL PROFILE: T1-1, soil D (unit 1) and buried DESCRIBED BY: M. N. Machette.

DATE: December 14, 1978

soil E (unit 3), trench 1.

PARENT MATERIAL: Scarp colluvium (unit 1) over coarse-grained alluvium (unit 3 ).

AGE: Late to middle Holocene (unit 1), middle to early Holocene (unit 3 ).

LOCATION: North wall trench 1, $21.65 \mathrm{~m}$ east of headwall, NW1/4NE $1 / \mathrm{NE}^{1 / 4} / 4$ sec. 29, T. 3 S., R. 2 W., Magdalena 15-minute quadrangle.

GEOGRAPHICAL LANDSCAPE: Toe of fault scarp on broad piedmont slope.

SOIL DEVELOPMENT: Soil D, weak; soil E, very weak.
ELEVATION: $1,920 \mathrm{~m}$
SLOPE: $2 \frac{1}{2}^{\circ}$
ASPECT: N. $60 \mathrm{E}$.
EROSION: None

CLIMATE: Semiarid: estimated mean annual temperature, 10-11 ${ }^{\circ} \mathrm{C}$; mean-annual precipitaton, $30 \mathrm{~cm}$.

VEGETATION: Short grasses, yucca, cholla; no junipers below scarp.

REMARKS: Abundant roots as deep as $15 \mathrm{~cm}$, root hairs as deep as $70 \mathrm{~cm}$; 2Bcab may have been mixed with $\mathrm{Cn}$ above.

\begin{tabular}{|c|c|c|c|c|c|c|c|c|c|}
\hline $\begin{array}{l}\text { Sample } \\
\text { No. }\end{array}$ & $\begin{array}{l}\text { Depth } \\
(\mathrm{cm})\end{array}$ & Horizon & Color & Texture & Structure & $\begin{array}{l}\text { Consist- } \\
\text { ence }\end{array}$ & $\begin{array}{l}\text { Clay } \\
\text { films }\end{array}$ & $\mathrm{CaCO}_{3}$ & Comments \\
\hline T1-1a--- & $0-12---$ & A------ & $10 \underline{\mathrm{YR}} 4 / 3 \mathrm{~d}----$ & $\begin{array}{l}\text { gSaL } \\
\text { to sg. }\end{array}$ & vwmpl---- & ss, & n.d.--- & None------ & Clear, smooth boundary. \\
\hline $\mathrm{T} 1-1 \mathrm{~b}---$ & $12-31--$ & B------ & $\begin{array}{l}9 \mathrm{YR} 3.5 / 3.5 \mathrm{~m}, \\
10 \mathrm{YR} 4.5 / 3 \mathrm{~d} .\end{array}$ & vgSaL--- & $\begin{array}{l}\text { wfsab } \\
\text { to sg. }\end{array}$ & ss, & n.d.-.-- & None----- & Gradual, smooth boundary. \\
\hline T1-1c--- & $31-50--$ & $\mathrm{Cn}-----$ & $\begin{array}{l}9 \mathrm{YR} 3 / 4 \mathrm{~m} \\
10 \underline{Y} 3.5 / 3 \mathrm{~d} .\end{array}$ & gSaL---- & $\begin{array}{l}\text { vwfsab } \\
\quad \text { to } \mathrm{sg}\end{array}$ & ss & n.d.-.-- & None------ & Gradual, wavy boundary. \\
\hline$T 1-1 d---$ & $50-64--$ & 3Bcab-- & $\begin{array}{c}8 Y \mathrm{YR} 3.5 / 4 \mathrm{~m}, \\
10 \text { YR } 6 / 3 \mathrm{~d} .\end{array}$ & vgSaL--- & sg------- & ss, & n.d.-.-- & VW stg I & Diffuse, wavy boundary. \\
\hline T1-1e--- & $64-90--$ & 3Ccab-- & $\begin{array}{l}9 \mathrm{YR} 3 / 3.5 \mathrm{~m} \\
10 \mathrm{YR} 6 / 3 \mathrm{~d}\end{array}$ & $\operatorname{vgLSa}(-)$ & sg- - - n- & so, & n.d.---- & vw stg I & Do. \\
\hline$T 1-1 f---$ & $90-110+$ & $3 \mathrm{Cnb}-\cdots$ & $10 \underline{Y R} 6 / 3 d-----$ & $\operatorname{vgLSa}(-)$ & sg---n- & so, & n.d.--- & $\begin{array}{l}\text { vw stg } I \text {, } \\
\text { sparse. }\end{array}$ & $\begin{array}{l}\text { Clay coatings }(7.5 \text { YR } 5 / 4 d) \\
\text { on clasts. }\end{array}$ \\
\hline
\end{tabular}


Trench-site 2 is at an altitude of $2,036-2,041 \mathrm{~m}$ $(6,680-6,700 \mathrm{ft}, \mathrm{pl} .2)$ on the central part of the fan, about $50 \mathrm{~m}$ west of U.S. Forest Service Road 505 and about $10 \mathrm{~m}$ north of a jeep trail leading to the west from the road. Access to the site is via road 505, which nearly parallels the scarp from Water Canyon, on the south, to the Courtney Ranch (sec. 27, T. 2 S., R. 3 W.), about 6.5 $\mathrm{km}$ to the north of trench 2. The trench was oriented S. $70^{\circ} \mathrm{W}$., perpendicular to the trend of the scarp.

GEOLOGIC INVESTIGATIONS

Trench 2 was excavated on the broad, moderately sloping, constructional surface of the alluvial fan that emanates from Shakespeare Canyon. The drainage from Shakespeare Canyon now follows a course around the north margin of the fan where it is entrenched in a deep channel. The few arroyos that originate on the fan expose a strongly developed relict soil (soil $\mathrm{H}$ ) on the upthrown side of the fault (fig. 6). Soil $\mathrm{H}$ (profile T2-30, table 5) was described and sampled for laboratory characterization where it was best developed, on the western end of trench 2. Although soil $H$ is on sandy gravel, it contains one of the thickest and most clayey argillic B horizons that I have seen in the Southwest. The Bt horizon is $155 \mathrm{~cm}$ thick and contains a maximum of 36 percent clay in the less-than 2-mm fraction, strong clay films on ped faces, and reddish-brown $(4 Y R-5 Y R)$ hues. These features are all indicators of a strongly developed soil. The parent materials for soil $H$ (units 5 and 6 , pl. 1B) probably had 2-5 percent clay (in the $<2$-mm fraction) and 75-80 percent gravel; thus, the alluvium probably had an initial clay content of $0.5-1$ percent (whole-sample basis).

To quantify the development of this soil, I have made calculations of its clay content on the basis of both percent thickness and weight (table 6). These calculations were made for clay that has accumulated in the $B$ horizon but not the underlying $C$ horizon. An initial clay content of 1 percent was used as a baseline value, but this value may be low if the alluvium was initially finer grained upwards. Bulk-density values were not available due to the soils' gravelly texture, so I assumed that it had an initial density of about $1.6 \mathrm{~g} / \mathrm{cm}^{3}$ (grams per cubic centimeter), which is typical of this material. Subsequent accumulation of pedogenic clay, compaction, and infiltration of silt and fine sand would cause the density of the soil to increase. I used a value of $1.6 \mathrm{~g} / \mathrm{cm}^{3}$ for the bulk density of the B horizon of the soil which yields conservative values for weight increase in clay.

The clay increase in the Bt horizon of soil $\mathrm{H} 15 \mathrm{~B} 1 \mathrm{t}$ through 5B3t subhorizons) is $13.5 \mathrm{~cm}$ and $21.5 \mathrm{~g} / \mathrm{cm}^{2}$ (table 6). The former value is the product of clay increase in the Bt horizon times thickness of the Bt horizon, divided by 100 (percent). This value represents the thickness of pure clay added to the Bt horizon. The latter value represents the clay that has been added to each $1-\mathrm{cm}^{2}$ (square centimeter) column of parent material through the Bt horizon.

Although these types of clay data are available for some soils in southern New Mexico (Gile and Grossman, 1979), comparisons are complicated by two factors: (1) old B horizons of calcic soils are commonly engulfed by upward accumulating horizons of carbonate, or are eroded, and (2) there can be no assurance that the initial clay content of the $\mathrm{C}$ horizon represents that of the soil profile if layered parent materials are present. However, a comparison (table 6) can be made with middle and late Pleistocene soils of the Colorado Piedmont near Golden, Colo., where carbonate engulfment and layering are not severe problems. Golden has about the same mean-annual temperature $\left(10-11^{\circ} \mathrm{C}\right)$ as trench site 2 but is significantly wetter (mean-annual precipitation about $50 \mathrm{~cm}$ versus $35 \mathrm{~cm}$ for trench 2; Machette, Birkeland, Markos, and Guccione, 1976).

The middle Pleistocene Verdos Alluvium at Golden is locally interbedded with the Lava Creek ash bed (formerly the type "O" Pearlette ash; Izett and Wilcox, 1982), a 600,000-year-old tephra (Naeser and others, 1973). Deposition of the Verdos must have ended after $600 \mathrm{ka}$ ago and perhaps as late as $500 \mathrm{ka}$ ago. The Verdos Alluvium contains strong soils that are basically similar to soil $\mathrm{H}$. The soil on the Verdos has a gravelly parent material (2Cox horizon, 82 percent gravel) derived from Precambrian rocks. The soil contains a $B$ horizon that is reddish brown (5YR hue) and has a maximum of 29 percent clay (in the $<2-\mathrm{mm}$ fraction) and abundant clay films; it has strong, coarse ped structure and is $112 \mathrm{~cm}$ thick. The degree of apparent development of the B horizon in the Verdos soil might be slightly less than that of relict-soil $\mathrm{H}$ at trench 2; however, the total clay content is considerably less. The total clay accumulated in the Verdos soil was calculated on the basis of alluvium that initially had 80 percent gravel, a bulk density of $1.6 \mathrm{~g} / \mathrm{cm}^{3}$, and 1 percent total clay. The Verdos soil has a net clay increase of $4.1 \mathrm{~cm}$ in thickness and $6.5 \mathrm{~g} / \mathrm{cm}^{2}$ in weight (table 6), values which are about one-third those of soil $\mathrm{H}$ at trench 2 .

Similar calculations of clay accumulation were made by Pierce (1979, p. F25, table 2) for soils developed on glacial deposits of late Pleistocene age. His calculations for the Louviers Alluvium near Denver, Colo., which is between $100 \mathrm{ka}$ and $150 \mathrm{ka}$ old, are based on data of Machette, Birkeland, Burke, and others (1976); and Machette, Birkeland, Markos, and Guccione (1976). Soils on the Louviers show clay increases of between 1.5-2.3 $\mathrm{cm}$ and 2.2-2.7 $\mathrm{cm}$. (For further discussion, I use $2.2 \mathrm{~cm}$ 


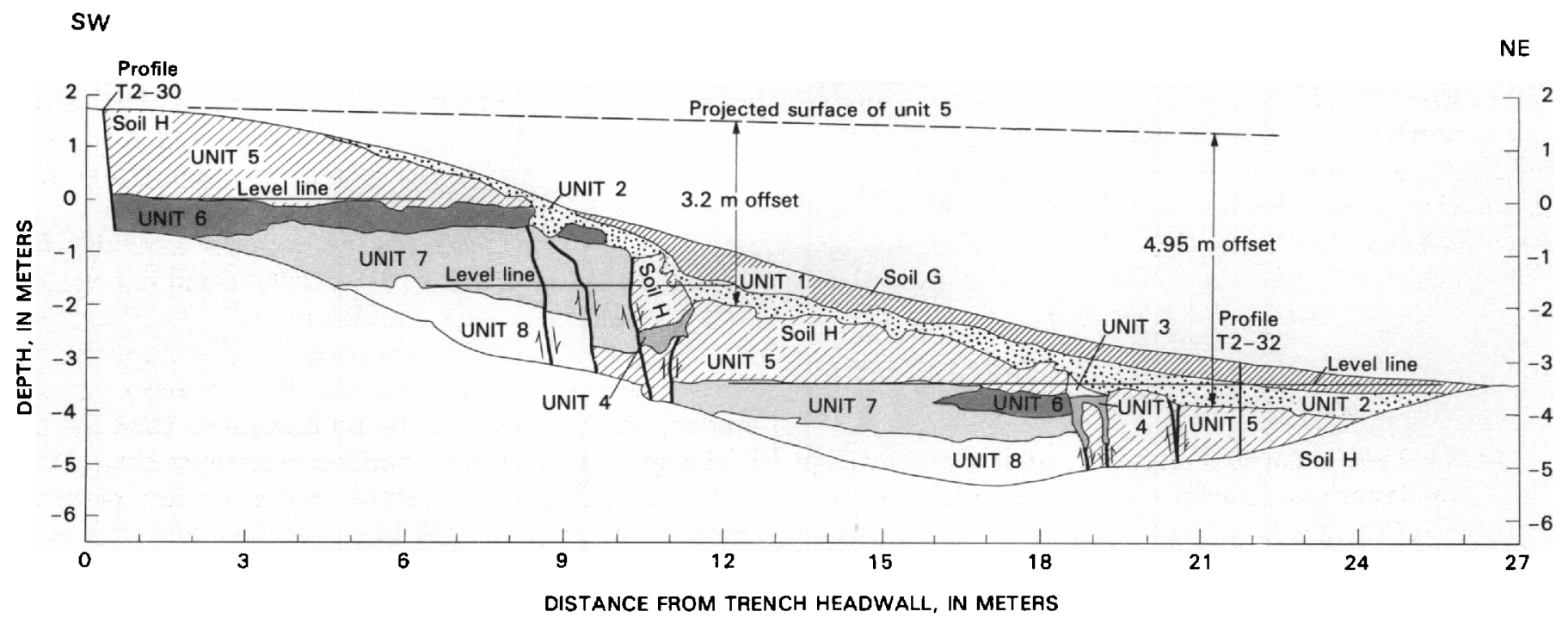

FIGURE 6.-Simplified sketch map of major geologic and soil units in trench 2. See plate 1B for detailed section; north wall of trench was mapped. Horizontal and vertical distances measured from upper end of trench and highest level line, respectively. Direction of movement along faults (heavy lines) shown by arrows. Units 1-8 are described in the section on "Description of Soil Parent Materials" on plate 1. Soils G and H are described in the section on "Description of Soil Horizons in Trench 2."

of clay, the average value for the Louviers soils.) Inasmuch as the Louviers Alluvium is only about onequarter as old as the Verdos Alluvium (120-150 ka versus $500-600 \mathrm{ka}$ ), the clay values for the soil on the Louviers must be increased by a factor of four to compare it to the soil on the Verdos. The soil on the Verdos has $4.1 \mathrm{~cm}$ of clay increase (table 6), whereas the Louviers soil would have considerably more clay $(8.8 \mathrm{~cm})$ if it had formed in the same time interval $(500,000-600,000$ years).

These data show that some soils in the Golden-Denver area of the Colorado Piedmont have accumulated between 4.1 and $8.8 \mathrm{~cm}$ of clay during an interval of $500,000-600,000$ years. At trench 2, the Bt horizon of soil $\mathrm{H}$ (table 6) has about a 13-cm clay increase, or about 1.5 to 3 times as much clay as on the Colorado Piedmont. On a weight basis, soil $\mathrm{H}$ has accumulated slightly more than 3 times as much clay $\left(21.5 \mathrm{~g} / \mathrm{cm}^{2}\right.$ versus $\left.6.5 \mathrm{~g} / \mathrm{cm}^{2}\right)$ as the soil on the Verdos Alluvium. Thus, on either a percent-centimeter basis or on a weight basis, soil $\mathrm{H}$ has substantially more clay than 500- to 600-ka-old soils on the Colorado Piedmont. If rates of clay accumulation are comparable in the two areas, then the relict soil at trench 2 (and the alluvium on which it is formed) should be more than $1 \mathrm{Ma}$ old. The certainty that the soil and alluvium (units 5-8) at trench 2 must be rather old is especially relevant because their age has implications for the recurrence interval of faulting at this site.

On the basis of the gross characteristics of soil $\mathrm{H}$ and the laboratory data (profile T2-30, table 5), I argue, conservatively, that soil $\mathrm{H}$ is as old as or older than the Verdos soil (that is, 0.5 Ma; Machette, Birkeland,
Markos, and Guccione, 1976). If this is true, then soils of central New Mexico must have higher rates of clay accumulation than soils on the Colorado Piedmont. This hypothesis is also supported by soil data from the two northern trenches, 3 and 4 . The high rates are, in my opinion, largely the result of downward infiltration of abundant clay supplied by desert loess, much as calcareous soil horizons are largely the product of downward leaching of airborne calcium carbonate (Gile and Grossman, 1979; Machette, 1985). Because the importance of eolian contribution of clay to argillic B horizons, especially in arid and semiarid areas, appears to have been underestimated in the past, I believe that many interpretations of the genesis of arid and semiarid soils are strongly influenced by classical processes of weathering (see Birkeland, 1974, for a discussion of processes of weathering).

The lower part of soil $\mathrm{H}$ (profile T2-30) consists of several horizons of slightly oxidized alluvium (Cox horizons, pl. 1B). These horizons are sandy gravel containing moderately oxidized clay laminae, depositional layers of penecontemporaneous, mechanically infiltrated clay (Walker and others, 1978). These horizons are not B horizons because the clay laminae are not considered to be pedogenic products and because bedding is still preserved in these horizons. At trench 2 , abundant clay laminae are commonly found well below the B horizon; they decrease in abundance downward and within the soil parent material (unit 7). I think that these laminae are the products of downward-infiltrating, clay-rich stream water that spreads laterally along boundaries of differential porosity within the alluvium. The distribution of 
TABLE 5.-Laboratory data and field description for soil $H$, profile $72-30$, trench 2, La Jencia fault LABORATORY DATA

[Grain-eize analyses of noncalcareous soil fraction in percent; vc, very coarse; c, coarse; m, medium; f, fine; vf, very fine; $\mu$ m, micrometers; <, lese than; >, greater than. Laboratory analysee by Donald Cheney, U.S. Geological Survey]

\begin{tabular}{|c|c|c|c|c|c|c|c|c|c|c|c|c|c|c|c|c|}
\hline \multirow{2}{*}{\multicolumn{3}{|c|}{$\begin{array}{l}\text { Grain-size classes-- } \\
\text { Grain-size categories-- }\end{array}$}} & \multicolumn{3}{|c|}{$<2-\mathrm{mm}$ fraction } & \multicolumn{5}{|c|}{ Sand $(\mathrm{mm})$} & \multicolumn{2}{|c|}{ Silt $(\mu \mathrm{m})$} & \multicolumn{2}{|c|}{ Clay $(\mu \mathrm{m})$} & \multicolumn{2}{|c|}{ Whole sample } \\
\hline & & & Sand & Silt & Clay & ve & $\mathrm{c}$ & $m$ & $f$ & $\mathrm{vf}$ & $c$ & $\mathrm{f}$ & c & $\mathrm{f}$ & & \\
\hline Grain sizes & $s(\mathrm{~mm})----$ & - & $\overline{(2.0-}$ & $\left(0.05^{-}\right.$ & $(<0.002)$ & $(2-1)$ & $(1-0.5)$ & $(0.5-$ & $(0.25-$ & $10.1-$ & $(50-20)$ & $(20-2)$ & $(2-0.5)$ & $(<0.5)$ & $(<2 \mathrm{~mm})$ & $(>2 \mathrm{~mm})$ \\
\hline $\begin{array}{l}\text { Sample } \\
\text { No. }\end{array}$ & $\begin{array}{c}\text { Depth } \\
(\mathrm{cm})\end{array}$ & $\begin{array}{l}\text { Horizon or } \\
\text { subhorizon }\end{array}$ & $0.05)$ & $0.002)$ & & & & $0.25)$ & $0.1)$ & $0.05)$ & & & & & & \\
\hline T2-30a-- & $0-7-\cdots$ & $5 \mathrm{~A}^{------}$ & 52.7 & 36.5 & 10.8 & 9.1 & 11.9 & 10.6 & 10.6 & 10.5 & 20.4 & 16.1 & 4.5 & 6.3 & 66.7 & 33.3 \\
\hline T2-30b-- & $7-17---$ & $5 B 1 t-\cdots$ & 48.7 & 38.9 & 12.4 & 9.7 & 8.9 & 9.5 & 11.2 & 9.4 & 17.3 & 21.6 & 4.7 & 7.7 & 20.2 & 79.8 \\
\hline T2-30c-- & $17-37---$ & $5 B 21 \mathrm{t}-\cdots$ & 47.9 & 36.4 & 15.7 & 10.4 & 9.6 & 9.2 & 10.4 & 8.3 & 18.9 & 17.5 & 5.3 & 10.4 & 51.4 & 48.6 \\
\hline$T 2-30 d--$ & $37-82 \cdots-$ & $5 B 22 t--$ & 48.0 & 15.8 & 36.2 & 6.3 & 8.9 & 11.1 & 13.7 & 8.0 & 7.3 & 7.5 & 4.5 & 31.7 & 61.9 & 38.1 \\
\hline$T 2-30 e^{--}$ & $82-121--$ & $5 B 23 t-\cdots$ & 79.5 & 8.4 & 12.1 & 29.3 & 24.5 & 15.6 & 7.6 & 2.5 & 2.5 & 5.9 & 1.7 & 10.4 & 28.5 & 71.5 \\
\hline T2-30r-- & $121-162-$ & $583 t \cdots$ & 85.4 & 7.1 & 7.5 & 35.4 & 25.7 & 15.4 & 6.6 & 2.3 & 2.5 & 4.6 & 1.0 & 6.5 & 32.8 & 67.2 \\
\hline $\mathrm{T} 2-30 \mathrm{~g}=-$ & $162-188-$ & 6 clox & 81.0 & 11.1 & 7.9 & 13.3 & 21.3 & 26.4 & 17.4 & 2. & 2.8 & 8.3 & 1.2 & 6.7 & 40.9 & 59.1 \\
\hline T2-30n-- & $188-240+$ & $6 \mathrm{C} 20 \mathrm{x} \ldots$ & 86.2 & 9.2 & 4.6 & 31.3 & 26.2 & 19.4 & 9.3 & 2.9 & 2.1 & 4.2 & .6 & 4.0 & 19.9 & 80.1 \\
\hline
\end{tabular}

|Grain-size analyses of gravel fraction, organic-matter content, and calcium carbonate content in percent; bulk donsity in g/cm ${ }^{3}$; f fine; m, medium; c, coarse; <, less than; >, greater than; $n$.d., not determined. Laboratory analyses by Donald Cheney, U.S. Geological Survey]

\begin{tabular}{|c|c|c|c|c|c|c|c|c|c|c|}
\hline \multirow[b]{2}{*}{$\begin{array}{l}\text { Grain-size categories } \\
\text { Grain sizes }(\mathrm{mm})- \\
\text { Sample } \\
\quad \text { No. }\end{array}$} & \multicolumn{3}{|c|}{ Gravel $(>2 \mathrm{~mm})$} & \multirow[b]{2}{*}{$\begin{array}{l}\text { Organic } \\
\text { matter }\end{array}$} & \multirow[b]{2}{*}{${ }^{\ddagger} \mathrm{pH}$} & \multicolumn{2}{|c|}{ Bulk density } & \multicolumn{2}{|c|}{$\mathrm{CaCO}_{3}$} & \multirow[b]{2}{*}{ Texture } \\
\hline & $\frac{f}{(2-19)}$ & $\frac{m}{(19-76)}$ & $\frac{c}{(>76)}$ & & & $<2 \mathrm{~mm}$ & $\begin{array}{l}\text { Whole } \\
\text { sample }\end{array}$ & $<2 \mathrm{~mm}$ & $\begin{array}{l}\text { Whole } \\
\text { sample }\end{array}$ & \\
\hline $\begin{array}{l}\mathrm{T} 2-30 \mathrm{a}- \\
\mathrm{T} 2-30 \mathrm{~b}- \\
\mathrm{T} 2-30 \mathrm{c}- \\
\mathrm{T} 2-30 \mathrm{~d}- \\
\mathrm{T} 2-30 \mathrm{e}- \\
\mathrm{T} 2-30 \mathrm{f} \\
\mathrm{T} 2-30 \mathrm{~g} \\
\mathrm{~T} 2-30 \mathrm{n}\end{array}$ & $\begin{array}{l}85.0 \\
18.0 \\
64.0 \\
42.0 \\
66.0 \\
72.5 \\
28.5 \\
62.0\end{array}$ & $\begin{array}{l}15.0 \\
61.0 \\
36.0 \\
58.0 \\
34.0 \\
27.5 \\
71.5 \\
38.0\end{array}$ & $\begin{array}{r}0.0 \\
21.0 \\
.0 \\
.0 \\
.0 \\
.0 \\
.0 \\
.0\end{array}$ & $\begin{array}{l}\text { n.d. } \\
\text { n.d. } \\
\text { n.d. } \\
\text { n.d. } \\
\text { n.d. } \\
\text { n.d. } \\
\text { n.d. } \\
\text { n.d. }\end{array}$ & $\begin{array}{l}6.8 \\
6.9 \\
7.1 \\
7.4 \\
6.9 \\
7.1 \\
7.2 \\
7.2\end{array}$ & $\begin{array}{l}\text { n.d. } \\
\text { n.d. } \\
\text { n.d. } \\
\text { n.d. } \\
\text { n.d. } \\
\text { n.d. } \\
\text { n.d. } \\
\text { n.d. }\end{array}$ & $\begin{array}{l}\text { n.d. } \\
\text { n.d. } \\
\text { n.d. } \\
\text { n.d. } \\
\text { n.d. } \\
\text { n.d. } \\
\text { n.d. } \\
\text { n.d. }\end{array}$ & $\begin{array}{r}* 0 \\
* .0 \\
.0 \\
.3 \\
.6 \\
1.7 \\
.3 \\
.3 \\
.2\end{array}$ & $\begin{array}{l}\text { n.d. } \\
\text { n.d. } \\
\text { n.d. } \\
\text { n.d. } \\
\text { n.d. } \\
\text { n.d. } \\
\text { n.d. } \\
\text { n.d. }\end{array}$ & $\begin{array}{l}\text { Gravelly, sandy loam. } \\
\text { Very gravelly loam. } \\
\text { Gravelly loam. } \\
\text { Gravelly, sandy clay minus. } \\
\text { Very gravelly, sandy loam minus. } \\
\text { Very gravelly, loamy sand. } \\
\text { Very gravelly, loamy sand plus. } \\
\text { Very gravelly, loamy sand minus. }\end{array}$ \\
\hline
\end{tabular}

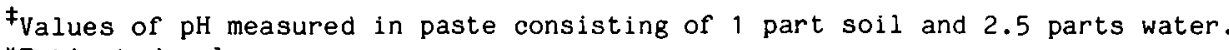

* Estimated value. 


\section{FIELD DESCRIPTION}

[Seo table 1 for abbrevations]

SOIL PROFILE: T2-30, soil G, trench 2.

PARENT MATERIAL: Coarse-grained alluvium (units 5 and 6 ).

AGE: Middle Pleistocene.

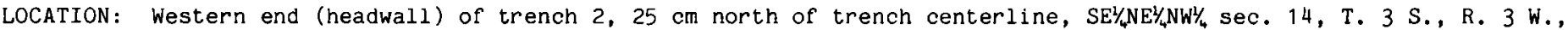
Magdalena 15 -minute quadrangle.

GEOGRAPHICAL LANDSCAPE: Relict surface of alluvial fan.

SOIL DEVELOPMENT: Soil G, strong.
ELEVATION: $2,036 \mathrm{~m}$
SLOPE: $\quad 4 \frac{1}{2}-5^{\circ}$
ASPECT: N. $70^{\circ} \mathrm{E}$.
EROSION: Slight.

CLIMATE: Semiarid: estimated mean annual temperature, 9-10 ${ }^{\circ} \mathrm{C}$; mean-annual precipitation, $35 \mathrm{~cm}$.

VEGETATION: Short grass, pinon pine, juniper, mountain mahogany, and cholla.

REMARKS: Very thick, red argillic B horizon developed in coarse-grained alluvium. Clay laminae above a depth of 162 cm masked by 5Bt horizon, but laminae prominent below 5B3t.

\begin{tabular}{|c|c|c|c|c|c|c|c|c|c|}
\hline $\begin{array}{l}\text { Sample } \\
\text { No. }\end{array}$ & $\begin{array}{l}\text { Depth } \\
(\mathrm{cm})\end{array}$ & Horizon & Color & Texture & Structure & $\begin{array}{l}\text { Consist- } \\
\text { ence }\end{array}$ & $\begin{array}{l}\text { Clay } \\
\text { films }\end{array}$ & $\mathrm{CaCO}_{3}$ & Comments \\
\hline T2-30a-- & $0-7----$ & $5 \mathrm{~A}------$ & $\begin{array}{l}8 \mathrm{YR} 4.5 / 4 \mathrm{~d} \\
7.5 \mathrm{YR} 3.5 / 4 \mathrm{~m}\end{array}$ & gSaL---- & $\begin{array}{l}\text { wmpl to } \\
\text { wf sab. }\end{array}$ & ss, & None----- & None-- & $\begin{array}{l}\text { Overlain by } 2-c m-t h i c k \text { desert pavement, } \\
\text { sample } \mathrm{T} 2-14 \text {. }\end{array}$ \\
\hline T2-30b-- & 7-17---- & 5Blt---- & $\begin{array}{l}6.5 \underline{Y R} 5 / 6 \mathrm{~d} \\
5 \underline{Y R} 3 / 3.5 \mathrm{~m}\end{array}$ & vgL-- - & $\begin{array}{l}\text { wmsab to } \\
\text { wfsab. }\end{array}$ & $\begin{array}{l}\text { ms, } \\
\text { mp. }\end{array}$ & $\begin{array}{l}\text { Thin on } \\
\text { gravel. }\end{array}$ & None. & \\
\hline$T 2-30 c--$ & $17-37---$ & $5 B 21 t---$ & $\frac{7 Y R 5 / 6 \mathrm{~d}}{7.5 \underline{Y R} 4 / 4 \mathrm{~m}}$ & gL------ & $\begin{array}{l}\text { mosab to } \\
\text { mmsab. }\end{array}$ & ms, & $\begin{array}{l}\text { Medium on } \\
\text { gravel, } \\
\text { thin on } \\
\text { peds. }\end{array}$ & None. & \\
\hline T2-30d-- & $37-82---$ & $5 B 22 t---$ & $\frac{4 Y R 4 / 8 d}{5 Y R 3.5 / 3 m}$ & $\mathrm{gSaC}(-)-$ & $\begin{array}{l}\text { scsab to } \\
\text { smsab. }\end{array}$ & s,p. & $\begin{array}{c}\text { Thick on } \\
\text { gravel, } \\
\text { medium } \\
\text { on peds. }\end{array}$ & None. & \\
\hline T2-30e-- & $82-121--$ & $5 B 23 t---$ & $\frac{5 \mathrm{YR} 5 / 8 \mathrm{~d}}{5 \underline{\mathrm{YR}} 4 / 6 \mathrm{~m}}$ & vgSaL--- & $\begin{array}{l}\text { mmsab to } \\
\text { mf sab. }\end{array}$ & ss, & $\begin{array}{l}\text { Medium on } \\
\text { gravel, } \\
\text { thin on } \\
\text { peds. }\end{array}$ & None-- & $\begin{array}{l}\text { Peds distinctly less well developed than } \\
\text { in } 5 \text { B22t subhorizon. }\end{array}$ \\
\hline T2-30f-- & $121-162-$ & $5 B 3 t----$ & $\frac{5 \mathrm{YR} 5 / 8 \mathrm{~d}}{5 \underline{\mathrm{YR}} 4 / 6 \mathrm{~m}}$ & vgLSa--- & $\begin{array}{l}\text { wmsab to } \\
\text { wfsab. }\end{array}$ & $\begin{array}{l}\text { vss, } \\
\text { vsp. }\end{array}$ & $\begin{array}{l}\text { Thin on } \\
\text { gravel. }\end{array}$ & None. & \\
\hline T2-30g-- & $162-188-$ & $6 \mathrm{c} 10 \mathrm{x}---$ & $7.5 \underline{\text { YR }} 5 / 6 \mathrm{~d}----$ & vgLSa(+) & $\begin{array}{l}\text { wmsab } \\
\text { to } \mathrm{sg} \text {. }\end{array}$ & $\begin{array}{l}\text { vss, } \\
\text { vsp. }\end{array}$ & $\begin{array}{l}\text { Thin on } \\
\text { gravel. }\end{array}$ & None-- & $\begin{array}{l}5 \text { YR5/8d clay films, distinct clay } \\
\text { laminae in sandy top of unit } 6 .\end{array}$ \\
\hline T2-30h-- & $188-240+$ & $6 \mathrm{C} 20 x^{---}$ & $5 \underline{\text { YR }} 5 / 7 \mathrm{~d} \cdots$ & $\operatorname{vgLSa}(-)$ & sg-- & $\begin{array}{l}\text { vss, } \\
\text { po. }\end{array}$ & $\begin{array}{l}\text { Thin on } \\
\text { gravel. }\end{array}$ & None-- & $\begin{array}{l}2.5 \text { YR5/8 clay films, distinct clay } \\
\text { laminae in gravelly part of unit } 6 .\end{array}$ \\
\hline
\end{tabular}


TABLE 6.-Clay data for relict soil $H$ on alluvium of the upthrown fault block in trench 2, La Jencia fault, compared with a relict soil on the Verdos Alluvium near Denver, Colo.

[All values calculated for whole sample ( $>2 \mathrm{~mm}$ included); whole-sample clay contents calculated from grain-size data in table 5 . Data for soil on Verdos Alluvium from Machette, Birkeland, Burke, and others (1976)]

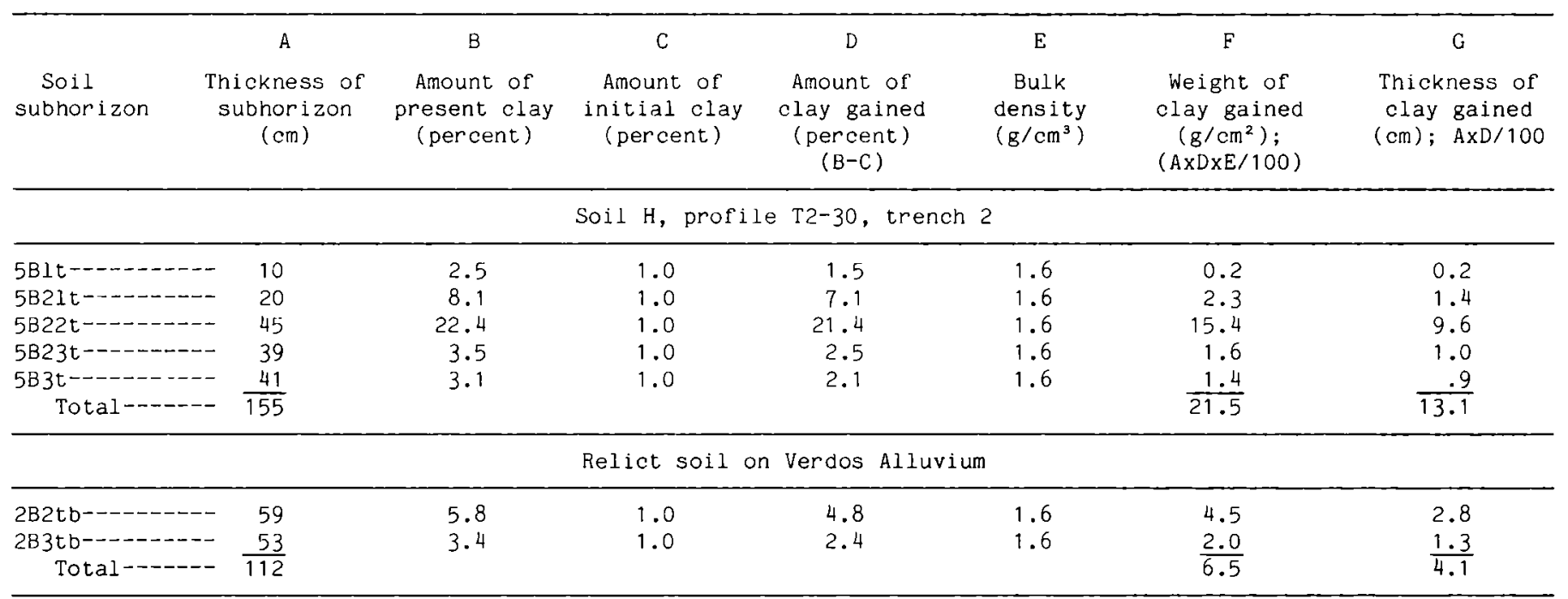

clay laminae is commonly discontinuous but parallel to sedimentary bedding.

Two minor faults about $9 \mathrm{~m}$ from the headwall of trench 2 displace units 7 and 8 (fig. 6, pl. 1B) but do not displace the base of unit 6 (6Cox horizon). Unit 7 thickens across these faults, which suggests that the faults were active during or before deposition of the unit. The individual faults offset alluvium 5-12 cm and about 40 $\mathrm{cm}$, and, although minor, they provide evidence of the oldest Quaternary movement along the La Jencia fault. These faults must date from middle Pleistocene or earlier, but they have not been active since that time. They clearly were most recently active much longer ago than either of the two major faults, which were exposed at $10.7 \mathrm{~m}$ and $19 \mathrm{~m}$ from the headwall of trench 2 . This interpretation does not preclude earlier movement on the major faults; in fact, by association, the evidence suggests that the major faults may have been active in the middle Pleistocene. The evidence necessary to document earlier movement along the major faults might be preserved at levels deeper than those exposed in the shallow excavation of trench 2 .

The prominent fault scarp at trench 2 is mainly the product of movement on the westernmost of two major faults $(10.7 \mathrm{~m}$ from headwall, pl. 1B). This fault places the uplifted, basal part of relict-soil $\mathrm{H}$ (7Cox horizon) against the downdropped upper part of buried-soil $\mathrm{H}$ (5Bt horizon). The fault bounds a $0.4-\mathrm{m}$-wide graben that, near the floor of the trench, is filled with a breccia composed of the fragments of the 5B2t horizon and material (6Cox-7Cn horizons) derived from the base of the former free-standing scarp. The breccia is covered by humic, light-brown, sandy pebble colluvium (sample T2-12, 4Cn horizon, pl. 1B) and a tilted slump block of soil $\mathrm{H}$ (5B2t horizon). The block was undermined by raveling loose gravel of the 6Cox horizon, collapsed from the free face of the scarp, and came to rest at the base of the scarp. Imbricated pebbles and cobbles and formerly vertical peds in the slump block now tilt about $55^{\circ}$ to the east (pl. 1B; arrows indicating former up direction).

A net offset of about $3.2 \mathrm{~m}$ across the largest of the two main faults was calculated by projecting the upthrown surface of soil $\mathrm{H}$ (unit 5) eastward and projecting the highest part of buried-soil $\mathrm{H}$ westward (5B2t horizon at about $11.5 \mathrm{~m}$ from the trench headwall, $\mathrm{pl}$. 1B), parallel to the bedding in underlying units. The small graben at the main fault is bounded on the east by two antithetic faults that $\operatorname{dip} 80^{\circ}-85^{\circ}$ to the west.

The second of the two main faults is expressed as a narrow zone about $19 \mathrm{~m}$ from the trench headwall (pl. 1B). The zone is marked by a major fault $18.5 \mathrm{~m}$ from the headwall, an associated antithetic graben-bounding fault at $19.2 \mathrm{~m}$, and a small synthetic normal fault at $20.5 \mathrm{~m}$. The net offset of soil $\mathrm{H}$ across this zone is about $1.75 \mathrm{~m}$; about one-third of the total offset observed in trench 2. The fault at $18.5 \mathrm{~m}$ has about $1.6 \mathrm{~m}$ of normal offset, whereas the east-bounding fault of the graben has about $0.15 \mathrm{~m}$ of steep reverse offset; therefore, the net offset across the graben is $1.45 \mathrm{~m}$ down to the east. Both of the graben-bounding faults are marked by fissures that are filled with loose, light-brown, sandy colluvium (4Cn horizon); these fissures extend about $1 \mathrm{~m}$ below the top of the 5B2t horizon on the downdropped fault block. 
Near the eastern end of trench 2, the upper part of soil $\mathrm{H}$ was eroded before it was buried by young colluvium in response to faulting. This erosion suggests that a small amount of offset may have occurred on one of the faults in the east end of trench 2 , at least enough to uplift soil $\mathrm{H}$ and erode $10-15 \mathrm{~cm}$ into the 5B2t horizon. The easternmost faults exposed in trench 2 form a closely spaced set that displaces the top of buried soil $\mathrm{H}$ about $35 \mathrm{~cm}$; however, these faults do not displace the colluvium (units 1 and 2) that buries soil $H$.

At trench 2, the faults that form the obvious scarp offset middle Pleistocene (0.5 Ma old) surficial deposits a total of about $5 \mathrm{~m}$. The offset mainly results from movement on two major faults having individual throws of about $3.2 \mathrm{~m}$ and $1.6 \mathrm{~m}$. Inasmuch as the most recent movement on both faults postdates the development of the 5B2t horizon of soil $\mathrm{H}$ and the faults do not displace the colluvium (units 1 and 2), movement on these faults must have been closely spaced in time or was synchronous. The most recent movement is no younger than the oldest colluvium (unit 2).

Although this recent faulting produced two separate scarps, postfault modification has since removed evidence of their original geometry (a doublet). The topographic profile at trench 2 (pl. 1B) shows slight steepening above each of the main faults. These steeper parts are not related to the faults but were formed during excavation; they do not continue away from the trench.

In trench 2, the two major faults $10.7 \mathrm{~m}$ and $19 \mathrm{~m}$ from the headwall, and a smaller fault at $20.5 \mathrm{~m}$, have the most recent movement. They displace relict-soil $\mathbf{H}$ of the alluvial fan of Shakespeare Canyon. Although this soil is now buried on the downthrown block, its development is comparable to the relict soil on the upthrown block (compare profile T2-30, table 5, to the lower part of profile T2-32, table 7). These two soils would not appear much different in development unless the lengths of time during which they formed were significantly different (that is, by perhaps 20 percent or more; 100,000 years).

For example, at trench 1 the development of buriedsoil E (profile T1-1, lower part) and surface-soil E (profile T1-2) differ markedly because they formed during periods of less than 1,000 years and $5,000-6,000$ years, respectively. If surface-soil $\mathrm{H}$ at trench 2 is at least $500 \mathrm{ka}$ old as I suggest, then 100,000 years less time for formation of its buried counterpart might not seem apparent or measurable. Thus, at trench 2 the best data for interpreting the timing of last fault movement comes from soil $\mathrm{G}$, which is developed on colluvium derived from erosion of the fault scarp.

The four units of colluvium in trench 2 form two main bodies that were recognized and differentiated on the basis of grain size and shape of clasts. The lower body has small wedges of colluvium, units 3 and 4 , which were derived from catastrophic collapse of the fault scarp. The upper, main part of the lower body is unit 2, which consists of 50-85 percent gravel of pebble- to small cobblesize clasts that coarsen to the west, toward the higher of the two scarps.

The upper body of colluvium (unit 1, A+B on fig. 6 and pl. 1B) was deposited during a waning stage of scarp degradation, as erosion slowly stripped the upper surface farther back, producing lower scarp-slope angles. Compared to unit 2, this unit is finer grained, having only 40-60 percent gravel. Of the coarse clasts, 30-70 percent are angular and 5-16 mm in length. The angular clasts were derived from the surface of soil $\mathrm{H}$, which is mantled by a desert pavement consisting of pebble-size angular clasts. At trench 2, desert pavement (sample T2-14, pl. 1B) covers 50-75 percent of the undisturbed ground surface and consists of about 80 percent, 5 - to 16-mm-long clasts; the remaining 20 percent is mainly granule-size gravel $(2-4 \mathrm{~mm})$ and sand $(<2 \mathrm{~mm})$. Thus, the angular clasts, found in place only as desert pavement, form by breaking of larger, near-surface clasts, presumably by frost action.

The lower, older body of colluvium was deposited during gravity- and debris-controlled processes of scarp degradation, whereas the upper, younger body of colluvium was deposited during a transition to washcontrolled processes (see Wallace, 1977, for a description of these processes). Near trench 2, the scarp has maximum slope angles of $10.5^{\circ}$ to $19^{\circ}$; these angles are within the range $\left(8^{\circ}-25^{\circ}\right)$ of wash-controlled processes described in Wallace's model.

The degradation of scarps is a continual process, albeit at rates that decline with age. As such, soils can form on the colluvium only when deposition is slower than the rate of soil formation. Thus, the recognition of a soil or soils on scarp colluvium, or any other material, signifies periods of surface stability or relatively slow rates of surface aggradation.

Soil $\mathrm{G}$ is formed on colluvial units 1 and 2 and has a weakly developed profile consisting of an A horizon and a thick weak B horizon (upper part of profile T2-32, table 7). The $B$ horizon is further divided into $B 1, B 21 \mathrm{~s}$, $\mathrm{B} 22 \mathrm{ca}$, and 2B3ca subhorizons, the lowermost of which is on unit 2. The $B 1$ and $B 21$ s subhorizons have moderate, fine to medium, subangular blocky structure, but there are no clay films on the faces of peds. The accumulation of clay in the $\mathrm{B}$ horizon (table 7) is not strong enough for an argillic B horizon. It is important, however, to note the slight reddening (7.5YR hues) of the B21s subhorizon and the overall thickness $(84 \mathrm{~cm})$ of the whole B horizon (table 7). The lack of a clearly defined argillic horizon may be caused by soil formation 
TABLE 7.-Laboratory data and field description for soils $G$ and $H$, profile T2-32, trench 2, La Jencia fault LABORATORY DATA

[Grain-size analypes of noncalcareous soil fraction in percent; vc, very coarse; $c$, course; m, medium; f, fine; vf, very fine; $\mu \mathrm{m}$, micrometers; <, less than; >, greater than. Laboratory analysee by Donald Cheney, U.S. Geological Survey]

\begin{tabular}{|c|c|c|c|c|c|c|c|c|c|c|c|c|c|c|c|c|}
\hline \multirow{2}{*}{\multicolumn{3}{|c|}{$\begin{array}{l}\text { Grain-size classes- } \\
\text { Grain-size categories- }\end{array}$}} & \multicolumn{3}{|c|}{$<2 \mathrm{~mm}$ fraction } & \multicolumn{5}{|c|}{ Sand $(\mathrm{mm})$} & \multicolumn{2}{|c|}{ Silt $(\mu \mathrm{m})$} & \multicolumn{2}{|c|}{ Clay $(\mu \mathrm{m})$} & \multicolumn{2}{|c|}{ Whole sample } \\
\hline & & & Sand & Silt & Clay & ve & c & m & $\mathrm{f}$ & $\mathrm{vf}$ & c & $f$ & $c$ & $f$ & & \\
\hline Grain sizes & $\mathrm{s}(\mathrm{mm})-\cdots$ & - & $\left(2.0^{-}\right.$ & $(0.05-$ & $(<0.002)$ & $(2-1)$ & $(1-0.5)$ & $(0.5-$ & $(0.25-$ & $10.1-$ & $(50-20)$ & $(20-2)$ & $(2-0.5)$ & $(<0.5)$ & $(<2 m m)$ & $(>2 \mathrm{~mm}$ \\
\hline $\begin{array}{c}\text { Sample } \\
\text { No. }\end{array}$ & $\begin{array}{l}\text { Depth } \\
(\mathrm{cm})\end{array}$ & $\begin{array}{l}\text { Horizon or } \\
\text { subhorizon }\end{array}$ & $0.05)$ & $0.002)$ & & & & $0.25)$ & $0.1)$ & $0.05)$ & & & & & & \\
\hline T2-32a-- & $0-10-\cdots$ & A---D---- & 55.2 & 35.3 & 9.5 & 14.0 & 12.4 & 10.2 & 8.4 & 10.2 & 21.5 & 13.8 & 2.9 & 6.6 & 54.9 & 45.1 \\
\hline$T 2-32 b^{--}$ & $10-28-\cdots$ & B1 $\ldots$ & 50.1 & 38.8 & 11.1 & 14.1 & 11.3 & 8.5 & 7.1 & 9.1 & 23.7 & 15.1 & 3.3 & 7.8 & 52.9 & 47.1 \\
\hline T2-32c-- & $28-40---$ & B21s- & 52.0 & 37.9 & 10.1 & 14.5 & 11.4 & 9.0 & 8.6 & 8.5 & 24.2 & 13.7 & 3.7 & 6.4 & 60.2 & 39.8 \\
\hline$T 2-32 d--$ & $40-57=-$ & B22ca---- & 49.8 & 38.9 & 11.3 & 12.7 & 10.5 & 8.2 & 8.8 & 9.6 & 23.9 & 15.0 & 3.9 & 7.4 & 48.7 & 51.3 \\
\hline T2-32e-- & $57-94---$ & 2B3ca----- & 47.8 & 40.5 & 11.7 & 12.4 & 9.3 & 8.0 & 8.2 & 9.9 & 25.4 & 15.1 & 4.7 & 7.0 & 26.7 & 73.3 \\
\hline T2-32f-- & $94-118--$ & 5B22tb---- & 51.8 & 22.6 & 25.6 & 11.2 & 11.1 & 11.4 & 11.3 & 6.8 & 5.7 & 16.9 & 4.1 & 21.5 & 49.3 & 50.7 \\
\hline $\mathrm{T} 2-32 \mathrm{~g}--$ & $118-157-$ & $5 \mathrm{~B} 23 \mathrm{tb}-$ & 56.5 & 27.9 & 15.6 & 9.0 & 11.2 & 13.7 & 14.1 & 8.5 & 7.5 & 20.4 & 3.1 & 12.5 & 43.7 & 56.3 \\
\hline $\mathrm{T} 2-32 \mathrm{~h}--$ & $157-175^{+}$ & $5 \mathrm{~B} 3 \mathrm{tb}-\cdots$ & 67.9 & 19.8 & 12.3 & 16.7 & 17.8 & 15.8 & 12.3 & 5.2 & 5.4 & 14.4 & 2.6 & 9.7 & 34.6 & 65.4 \\
\hline
\end{tabular}

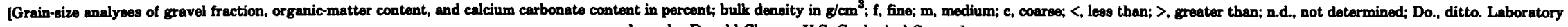
analysea by Donald Cheney, U.S. Geological Surveyl

\begin{tabular}{|c|c|c|c|c|c|c|c|c|c|c|}
\hline \multirow[b]{2}{*}{$\begin{array}{l}\text { Grain-size catagories } \\
\text { Grain sizes (mm)- } \\
\text { Sample } \\
\quad \text { No. }\end{array}$} & \multicolumn{3}{|c|}{ Gravel $(>2 \mathrm{~mm})$} & \multirow[b]{2}{*}{$\begin{array}{l}\text { Organic } \\
\text { matter }\end{array}$} & \multirow[b]{2}{*}{$\pm_{\mathrm{pH}}$} & \multicolumn{2}{|c|}{ Bulk density } & \multicolumn{2}{|c|}{$\mathrm{CaCO}_{3}$} & \multirow[b]{2}{*}{ Texture } \\
\hline & $\frac{f}{(2-19)}$ & $\frac{\mathrm{m}}{(19-76)}$ & $\frac{c}{(>76)}$ & & & $<2 \mathrm{~mm}$ & $\begin{array}{l}\text { Whole } \\
\text { sample }\end{array}$ & $<2 \mathrm{~mm}$ & $\begin{array}{l}\text { Whole } \\
\text { sample }\end{array}$ & \\
\hline 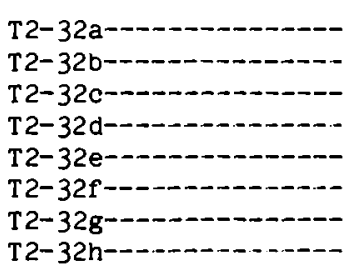 & $\begin{array}{l}87.5 \\
91.0 \\
95.5 \\
88.0 \\
49.0 \\
97.0 \\
40.0 \\
54.0\end{array}$ & $\begin{array}{r}12.5 \\
9.0 \\
4.5 \\
12.0 \\
51.0 \\
3.0 \\
60.0 \\
46.0\end{array}$ & $\begin{array}{l}0.0 \\
.0 \\
.0 \\
.0 \\
.0 \\
.0 \\
.0 \\
.0\end{array}$ & $\begin{array}{l}\text { n.d. } \\
\text { n.d. } \\
\text { n.d. } \\
\text { n.d. } \\
\text { n.d. } \\
\text { n.d. } \\
\text { n.d. } \\
\text { n.d. }\end{array}$ & $\begin{array}{l}7.0 \\
7.0 \\
7.3 \\
7.3 \\
\text { n.d. } \\
\text { n.d. } \\
\text { n.d. } \\
\text { n.d. }\end{array}$ & $\begin{array}{l}\text { n.d. } \\
\text { n.d. } \\
\text { n.d. } \\
\text { n.d. } \\
\text { n.d. } \\
\text { n.d. } \\
\text { n.d. } \\
\text { n.d. }\end{array}$ & $\begin{array}{l}\text { n.d. } \\
\text { n.d. } \\
\text { n.d. } \\
\text { n.d. } \\
\text { n.d. } \\
\text { n.d. } \\
\text { n.d. } \\
\text { n.d. }\end{array}$ & $\begin{array}{c}* 0.0 . \\
.0 \\
.3 \\
.6 \\
1.7 \\
.3 \\
.3 \\
.\end{array}$ & $\begin{array}{l}\text { n.d. } \\
\text { n.d. } \\
\text { n.d. } \\
\text { n.d. } \\
\text { n.d. } \\
\text { n.d. } \\
\text { n.d. } \\
\text { n.d. }\end{array}$ & $\begin{array}{l}\text { Gravelly, sandy loam. } \\
\text { Gravelly loam minus. } \\
\text { Gravelly, sandy loam to loam minus. } \\
\text { Very gravelly loam minus. } \\
\text { Do. } \\
\text { Very gravelly, sandy clay loam. } \\
\text { Very gravelly, sandy loam plus. } \\
\text { Very gravelly, sandy loam. }\end{array}$ \\
\hline
\end{tabular}

${ }_{*}^{ \pm}$Values of $\mathrm{pH}$ measured in paste consisting of 1 part soil and 2.5 parts water.

*Estimated value. 
SOIL PROFILE: T2-32, soil G (units 1 and 2) soil $H$ (unit 5), trench 4 .

PARENT MATERIAL: Colluvium (units 1 and 2) over coarse-grained alluvium (unit 5).

AGE: Late Pleistocene (units 1 and 2) and middle Pleistocene (unit 5).

LOCATION: North wall of trench $2,22.0 \mathrm{~m}$ east of headwall, SE $\mathrm{HSE}_{4} \mathrm{H}_{4} \mathrm{NW} / 4$ sec. $29, \mathrm{~T} .3 \mathrm{~S} ., \mathrm{R} .3 \mathrm{~W} .$, Magdalena 15-minute quadrangle.

GEOGRAPHICAL LANDSCAPE: Toe of fault scarp on alluvial $f a n$.

SOIL DEVELOPMENT: Soil G, weak to moderate; soil $\mathrm{H}$, strong.

ELEVATION: $2,030 \mathrm{~m}$ SLOPE: $6-7^{\circ} \quad$ ASPECT: N. $70^{\circ} \mathrm{E}$ EROSION: Slight.

CLIMATE: Semiarid: estimated mean annual temperature, 9-10 ${ }^{\circ} \mathrm{C}$; mean-annual precipitation, $35 \mathrm{~cm}$.

VEGETATION: Short grass, pinon pine, juniper, mountain mahogany, and cholla.

\begin{tabular}{|c|c|c|c|c|c|c|c|c|c|}
\hline $\begin{array}{l}\text { Sample } \\
\text { No. }\end{array}$ & $\begin{array}{l}\text { Depth } \\
(\mathrm{cm})\end{array}$ & Horizon & Color & Texture & Structure & $\begin{array}{l}\text { Consist- } \\
\text { ence }\end{array}$ & $\begin{array}{l}\text { Clay } \\
\text { films }\end{array}$ & $\mathrm{CaCO}_{3}$ & Comments \\
\hline T2-32a-- & $0-10-\cdots$ & $A-----$ & $10 \underline{\mathrm{YR}} 4 / 3.5 \mathrm{~d}-$ & gSaL----- & $\begin{array}{l}\text { wfpl to } \\
\text { sg. }\end{array}$ & ss, & None----. & None---- & $\begin{array}{l}\text { Partly removed, sampled } 15 \mathrm{~cm} \text { to } \\
\text { west at } 21.8 \mathrm{~m} \text { from trench headwall. }\end{array}$ \\
\hline $\mathrm{T} 2-32 \mathrm{~b}--$ & $10-28-\cdots$ & B1-.--- & $7.5 Y R 4.5 / 4 d$ & gL $(-)----$ & $\begin{array}{l}\text { mfsab to } \\
\text { wfsab. }\end{array}$ & $\begin{array}{l}\text { ss }(+) \\
\text { sp. }\end{array}$ & None------ & None. & \\
\hline T2-32c-- & $28-40-\cdots$ & B21s--- & $7.5 \underline{Y R} 4.5 / 4 d$ & $\begin{array}{l}\text { gSaL to } \\
\text { gL( }(-)\end{array}$ & $\begin{array}{l}\text { mfsab to } \\
\text { wfsab. }\end{array}$ & $\begin{array}{c}\mathrm{ms}(-) \\
\mathrm{mp}\end{array}$ & None----- & None---- & Slightly redder than B1 subhorizon. \\
\hline$T 2-32 d--$ & $40-57^{---}$ & B22ca-- & $7.5 \underline{Y R} 5 / 4 d--$ & $\operatorname{vgL}(-)---$ & $\begin{array}{l}\text { mmsab to } \\
\text { mfsab. }\end{array}$ & $\begin{array}{c}\mathrm{ms}(-) \\
\mathrm{sp}\end{array}$ & None-n-n-- & W stg I. & \\
\hline T2-32e-- & $57-94-\cdots$ & 2B3ca-- & $7.5 \underline{Y R} \cdots-\cdots$ & $\begin{array}{l}\operatorname{vgL}(-) \text { in } \\
\text { lenses. }\end{array}$ & mmsab--- & $\begin{array}{l}\mathrm{ms}(-) \\
\mathrm{sp}\end{array}$ & None----- & W stg II & $\begin{array}{l}\text { Coarser than unit } 1 \text {, average diameter } \\
\text { of gravel is } 15-20 \mathrm{~cm} \text {. }\end{array}$ \\
\hline T2-32f-- & $94-118--$ & $5 B 22 t b-$ & $5 \underline{Y R} 5 / 7 d----$ & vgSaCL-- & $\begin{array}{l}\text { scsab to } \\
\text { smsab. }\end{array}$ & $s, p$. & $\begin{array}{l}\text { Thick on } \\
\text { peds and } \\
\text { gravel. }\end{array}$ & $\begin{array}{l}\text { W stg I } \\
\text { on } B \text {. }\end{array}$ & Carbonate from soil $G$ (above). \\
\hline T2-32g-- & $118-157^{-}$ & $5 \mathrm{~B} 23 \mathrm{tb}-$ & $5 \underline{\text { YR } 5 / 7 \mathrm{~d}-\cdots}$ & $\operatorname{vgSaL}(+)-$ & $\begin{array}{l}\text { scsab to } \\
\text { smsab. }\end{array}$ & ms, & $\begin{array}{l}\text { Medium on } \\
\text { peds, } \\
\text { thick on } \\
\text { gravel. }\end{array}$ & None. & \\
\hline T2-32h-- & $157-175^{+}$ & $5 B 3 t b--$ & $\begin{array}{l}5 \text { YR } 5 / 7 \mathrm{~d} \text { to } \\
7.5 \underline{Y} 5 / 7 \mathrm{~d}\end{array}$ & vgSaL---- & $\begin{array}{l}\text { mmsab to } \\
\text { mf sab. }\end{array}$ & $\begin{array}{l}\text { ms-ss, } \\
\text { sp. }\end{array}$ & $\begin{array}{l}\text { Medium on } \\
\text { peds and } \\
\text { gravel. }\end{array}$ & None---- & $\begin{array}{l}\text { Clay laminae present in gravel } \\
\text { near base of subhorizon. }\end{array}$ \\
\hline
\end{tabular}


during slow aggradation, the illuviated clay having been distributed through a considerable thickness of material rather than being concentrated in a well-defined horizon as it would have been in a depositionally stable environment.

In trench 2, carbonate is present only in the lower part of the B horizon of soil G (pl. 1B), near the toe of the fault scarp. Here, two calcareous subhorizons of the $B$ horizon, the 2Bca and 2B2ca, were mapped on the basis of carbonate coatings on clasts. The 2B2ca (equivalent to the 2B3ca horizon of profile T2-32, table 7) has 1.7 percent carbonate and is the more calcareous of the two subhorizons. It generally has stage II morphology (Gile and others, 1966) and is characterized by thick carbonate coats on clasts and some disseminated carbonate nodules in the soil matrix.

The calcium carbonate in soil $\mathrm{G}$ is restricted to the $B$ horizon of the lower colluvium (unit 2), east of $19.5 \mathrm{~m}$ from the headwall of trench 2 (pl. 1B). Above and to the west, the soils are noncalcareous. As mentioned previously, the carbonate seems to be associated with the toe of the scarp, where a decrease in slope may permit percolation of carbonate-bearing soil water. Also, above the middle of the scarp the relatively intact 5B2t horizon under soil $\mathrm{G}$ (east of the fault at $19 \mathrm{~m}$ from the headwall) is an effective barrier that prevents deep infiltration of surface water. These two factors, slope position and an impermeable barrier, probably control local accumulation of carbonate in an area noticeably lacking in pedocal soils (see pl. 2 for the pedocal-pedalfer boundary along the Magdalena Mountains).

For the purposes of evaluating the age of soil G, I believe that the structure and thickness of the $\mathrm{B}$ horizon and the development of carbonate are the best indicators. These features suggest that soil $\mathrm{G}$ is older than the mid- to early Holocene soil $\mathrm{E}$ at trench 1 (profile T1-2). Soil G lacks noticeable clay films and an argillic horizon but has a moderate accumulation of carbonate. These features suggest no great age for the soil. Although soil $\mathrm{G}$ resembles the relict soil on Isaack's Ranch Alluvium (Gile and Grossman, 1979) in southern New Mexico, which is thought to be late Wisconsin in age (that is, 10-15 ka old), soil G is less calcareous because this area receives lesser amounts of calcareous dust (Machette, 1985). Thus, on the basis of the qualitative and quantitative properties of soil G, my best estimate is that it formed in the past 12,000 years and that most of the colluvium was deposited in about 3,000 years. This interpretation places the most recent movement of the fault at about $15 \mathrm{ka}$ ago. A limit of $\pm 3,000$ years is probably a reasonable error for this estimate.

\section{SUMMARY}

The following conclusions are drawn from the geologic investigations at trench 2 :
1. The La Jencia fault displaces alluvial deposits of late Pleistocene to middle or possibly early Pleistocene age and forms a scarp of fairly uniform height $(3-4 \mathrm{~m}$ ). There is no systematic relation of increasing scarp height versus age of faulted material as would be the case if the fault had been recurrently active in middle and late Pleistocene time. The scarp is the product of a single episode (or possibly two closely spaced, geologically indistinguishable events) of surface rupturing.

2. Fault-scarp-derived colluvium buries the welldeveloped soil $\mathrm{H}$ on the downdropped fault block. Two major colluvial units, recognized and differentiated on the basis of sorting, grain size, and shape, were emplaced by debris- and wash-controlled degradational processes acting on the fault scarp. The soil developed on colluvium, soil $\mathrm{G}$, is estimated to have formed in the past 12,000 years $( \pm 3,000$ years $)$.

3. Soil $\mathrm{H}$ is on the youngest faulted deposit (unit 5); it contains a thick, reddish argillic $B$ horizon. This soil is estimated to be at least $500 \mathrm{ka}$ old on the basis of the physical characteristics of its Bt horizon and a comparison of secondary clay content of $\mathrm{Bt}$ horizons in late and middle Pleistocene soils in Colorado.

4. The most recent faulting occurred about 15,000 years ago $( \pm 3,000$ years) and produced a total of about $5 \mathrm{~m}$ of offset on two closely spaced faults. This episode of faulting was preceded by a long period $(500,000$ years or more) in which there was no movement on the faults. A minor(?) episode of faulting occurred contemporaneously with deposition of unit 7 , more than $500 \mathrm{ka}$ ago.

5. Movement on two major faults exposed in trench 2 produced two closely spaced scarps, 3.2 and $1.6 \mathrm{~m}$ high. Erosion has erased all surface evidence of such fault-scarp geometry.

\section{TRENCH 3}

SETTING

Trench-site 3 is at an altitude of $1,884-1,890 \mathrm{~m}$ $(6,180-6,200 \mathrm{ft} ; \mathrm{pl}$. 2), just north of U.S. Highway 60 (fig. 3 ) between the Magdalena Mountains on the south and the southern part of the Bear Mountains on the west. The site lies in a wind gap between the two ranges and has markedly less precipitation and more eolian deposition than the sites of trenches 1 and 2 .

Numerous manmade and arroyo exposures suggest that this site is on an old landscape composed of mountain-front alluvial fans that prograde onto a wide piedmont slope. The piedmont slope dips gently $1{ }^{\circ} 2^{\circ}$ toward the northern center of the La Jencia basin. As mapped (pl. 2), the deposits that form the piedmont slope along La Jencia Creek are the uppermost part of 
the Sierra Ladrones Formation (Pliocene to as young as middle Pleistocene), whereas along the margins of the basin, the piedmont slope is formed by deposits younger than the Sierra Ladrones Formation.

Although soils at this site are calcareous, nearby exposures are only marginally calcareous (for example, in the roadcut along the south side of U.S. Highway 60 , sec. 17, T. 2 S., R. 3 W.; pl. 2) or are noncalcareous closer to the Magdalena Mountains to the south. Along the northern end of the Magdalena Mountains, the pedocalpedalfer boundary trends east-west several hundred meters south of trench-site 3 . The pedocal part of the piedmont has sparse shortgrass, cholla, yucca, and a few juniper trees, whereas the pedalfer part of the piedmont has, in addition, abundant juniper and some pinon pine trees. These vegetation associations closely reflect soil types of the La Jencia basin.

On the basis of the soil and vegetation associations at trench-site 3, I estimate that the mean-annual temperature and precipitation are $12^{\circ}$ and $27 \mathrm{~cm}$, respectively. For comparison, Magdalena, N. Mex., about $6 \mathrm{~km}$ to the west and $100 \mathrm{~m}$ higher (altitude $1,998 \mathrm{~m}$ $(6,556 \mathrm{ft}) ; \mathrm{pl} .2)$, has a mean-annual temperature of $11^{\circ} \mathrm{C}$ and precipitation of $30 \mathrm{~cm} \mathrm{(43} \mathrm{and} 55$ years of record, respectively; U.S. Weather Bureau, 1965). Both trenchsites 3 and 4 are relatively dry and warm, their microclimates being influenced by the relatively low terrain of the Bear Mountains to the west and a slightly lower altitude compared to sites 1 and 2 and Magdalena.

Trench 3 was near the southern margin of a thin, discontinuous blanket (plume) of eolian sand, one of two such deposits that flank La Jencia Creek (pl. 2). Beneath the sand is a stack of piedmont-slope and alluvial-fan deposits that were derived from Precambrian intrusive and metamorphic rocks and Oligocene monzonite in the northern Magdalena Mountains. Although lower Paleozoic rocks are exposed near Granite Mountain (secs. 11, 12,13 , and 14, T. 2 S., R. $3 \mathrm{~W}$.; pl. 2) and along the western flank of the Magdalena Mountains, none occur in the alluvium at trench-site 3.

Between trench-sites 2 and 3 , the La Jencia fault parallels the Magdalenas in a somewhat sinuous course 250-750 m east of the mountain front. South of U.S. Highway 60 , the fault scarps are relatively high $(5-7.4 \mathrm{~m})$ and steep $\left(18^{\circ}-25^{\circ}\right.$ maximum scarp-slope angle) and have well-preserved, sharp crests. At the highway, the fault bends $90^{\circ}$ to the north-northeast and gently curves north to La Jencia Creek (fig. 3). Although the scarps north of the highway are 4 to $6 \mathrm{~m}$ high and nearly as large as those to the south, the northern scarps are clearly more degraded (subdued), having lower scarp-slope angles $\left(15^{\circ}-19^{\circ}\right)$ and rounded or beveled crests, and are more deeply incised by arroyos. These characteristics suggest that the fault scarps near trench-site 3 are older than those at trench-sites 1 and 2 (see the section on "Scarp Morphology as an Indicator of Age" for further discussion).

\section{GEOLOGIC INVESTIGATIONS}

Trench 3 was excavated along a part of the fault that has subdued scarps. The original trench excavation was about $20 \mathrm{~m}$ long and traversed the scarp; it was later extended to $56 \mathrm{~m}$ in hopes of finding datable materials in the colluvium on the downthrown side of the fault. Unfortunately, no organic-rich materials, wood, charcoal, fossils, tephra, or artifacts were found. Although the headwall of trench 3 is $2.5 \mathrm{~m}$ west of the crest of the scarp (fig. 7), slight beveling of the surface of the upthrown block has removed all but the lower part (9Cca horizon, pl. 1C) of the surface soil (soil O) at the trench site. The $B$ horizon of soil $O$ is preserved about $35 \mathrm{~m}$ west (upslope) from the scarp crest where auger holes and soil pits showed that the calcareous (9Cca) horizon mapped in trench 3 is, in fact, the lower part of soil O. Soil O (profile T3-10, table 8), which was described from a pit $60 \mathrm{~m}$ west of the headwall of trench 3 , is formed on two parent materials, eolian sand (unit 8) and alluvium (unit 9). Soil $\mathrm{O}$ is characterized by a $\mathrm{Bt}$ horizon that is $72 \mathrm{~cm}$ thick, reddish brown $(5 Y R-6 Y R)$ and calcareous in the lower $60 \mathrm{~cm}$, and a well-developed $\mathrm{K}$ horizon that has stage III morphology (table 8).

Where preserved at the surface, soil $O$ is strongly developed. As previously mentioned, the Bt horizon is $72 \mathrm{~cm}$ thick, and all but the upper $13 \mathrm{~cm}$ is slightly calcareous (stages I and II morphology). The Bt horizon ranges from 23 percent clay in the lower part to a maximum of 30 percent in the upper part (table 8), indicating a minimum of 7 percent gain in clay content. Colors range from $5 Y R 4 / 6 \mathrm{~d}$ (yellowish-red) to $7.5 Y R 5 / 6 \mathrm{~d}$ (strong brown, where calcareous) and indicate a significant amount of mineral oxidation from the original parent material, which probably had $2.5 Y$ to $10 Y R$ hues. Ped structures within the Bt horizon range from moderate, coarse to medium subangular blocky. The Btca horizon has 3-5 percent calcium carbonate and has a sharp boundary with the underlying strongly calcareous, stage III $\mathrm{K} 2$ horizon (43 percent $\mathrm{CaCO}_{3}$ ). The K2 horizon is on unit 9, a fine-grained piedmontslope alluvial deposit containing 5-10 percent granuleto pebble-size clasts. Although only the top of the K2 horizon was exposed in the soil pit (profile T3-10), the same $\mathrm{K}$ horizon has stage III morphology where exposed in an adjacent arroyo. The $\mathrm{K}$ horizon is generally 0.5 to $1 \mathrm{~m}$ thick, although it may be locally overthickened along the arroyo.

The B horizon of soil $O$ occupies all of unit 8 (finegrained eolian sand or loess); thus I cannot determine 

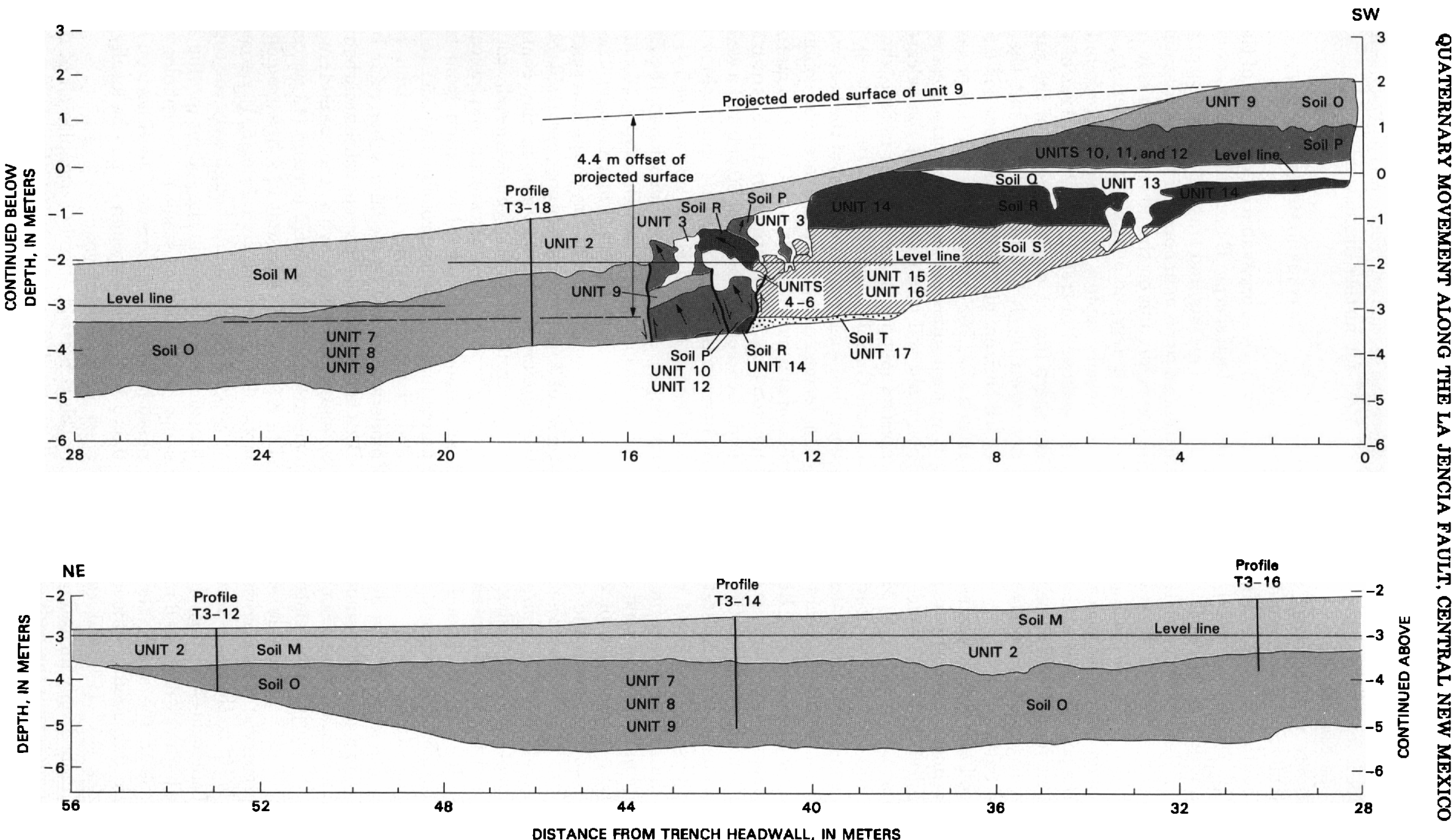

FIGURE 7.-Simplified sketch map of major geologic and soil units in trench 3. See plate 1C for detailed section; south wall of trench was mapped. Horizontal and vertical distances measured from upper end of trench and highest level line, respectively. Direction of movement along faults (heavy lines) shown by arrows. Arrows within blocks of soil P and soil R show their former upright directions. Units 1-17 are described in the section on "Description of Soil Parent Materials" on plate 1. Soils M, N, O, P, $Q, R, S$, and $T$ are described in the section on "Description of Soil Horizons in Trench 3." 
the initial clay content of unit 8 . Therefore, estimates of the age of soil $\mathrm{O}$ cannot be made by direct comparisons of clay content with that of other dated soils. The Magdalena Mountains form an orographic barrier adjacent to the southern part of the La Jencia basin (trench-sites 1 and 2), whereas the northern part of the basin has no significant barrier. As a result, eolian dust and carbonate flux rates must be substantially higher at trench-sites 3 and 4 than at sites 1 and 2 to the south. However, the soil's B-horizon color, structure, and amount of clay, and degree of development of the underlying $\mathrm{K}$ horizon preclude an age of late Pleistocene or younger. On the basis of the amount of carbonate in the $\mathrm{K}$ horizon of soil $\mathrm{O}$ and in other soils in New Mexico (Gile and Grossman, 1979; Machette, 1985) and Colorado (Machette, Birkeland, Markos, and Guccione, 1976), I estimate that soil $O$ began to form about $300 \pm 100 \mathrm{ka}$ ago (see later discussion of buried soil $\mathrm{O}$ in this section). Comparably developed soils are preserved on the Slocum Alluvium (Scott, 1963; Machette, Birkeland, Markos, and others, 1976) near Denver, Colo., although their carbonate horizons have less calcium carbonate due to lower rates of calcium carbonate influx (Bachman and Machette, 1977; Machette, 1985).

In the upthrown fault block at trench 3 , there are five buried soils ( $P$ through $T$ ) below the eroded remnants of soil $\mathrm{O}$ (pl. 1C). These soils all have moderate to strong Bt, Btca, and Cca or K horizons. It appears that thin sheetlike bodies of alluvium and eolian sand were periodically deposited at this site, probably as a result of changes in climate (from pluvial to interpluvial); intervening periods of surface stability were characterized by soil formation. These deposits and soils may record much of Quaternary time, inasmuch as each of the soils required several hundred thousand years to form. A well-documented but younger analog of this type of depositional environment is recorded in sediments of late Quaternary age along the piedmont slope of the Organ Mountains, northeast of Las Cruces, N. Mex. (Gile and Hawley, 1966).

Of the older deposits in trench 3 (units 9-17, pl. 1C), only unit 13 has a disconformable relationship to the adjacent deposits; it fills a channel that was cut into unit 14 along a northwest trend, oblique to the trench. Unit 13 was deposited during (or immediately after) a fairly arid climatic period as evidenced by the calcareous $\mathrm{B}$ horizons (14B2tca and 14B3tca) that it buries. Conversely, the climate in which soils formed on both units 13 and 14 , prior to final burial by units $10-12$, was probably semiarid to subhumid, as evidenced by the noncalcareous soil formed on unit 13. Thus, these two units and their associated soils record the sedimentary and pedogenic results of climatic changes, albeit of unknown magnitude and duration. The presence of generally calcareous soils throughout the stratigraphic sequence at trench 3 suggests that increased rainfall associated with Quaternary oscillations in climate was not of sufficient magnitude to cause complete leaching of previously developed pedocals (calcareous soils) and to transform them into pedalfers (noncalcareous soils).

Soil O (profile T3-10, table 8) is stripped from the surface of the upthrown fault block for tens of meters upslope from the crest of the scarp. Its erosion might normally be considered a product of postfaulting scarp modification, but the resulting fault-scarp colluvium (units 1-6, pl. 1C) was not derived from this soil. However, stratigraphically lower materials (that is, the 14B2tca, 14B3tca, and 14K horizons of soil R) are major components in the colluvium. Thus, it seems reasonable to postulate that erosion of soil $O$ from the upthrown block was related to a prior episode of faulting. The postulated older fault movement was large enough to cause stripping of $1 / 2-3 / 4 \mathrm{~m}$ of soil $\mathrm{O}$ from $60 \mathrm{~m}$ of the upper surface, yet was small enough so that no coherent slump blocks were generated from collapse of the scarp's free face (no blocks of soil $O$ are present in the scarp colluvium).

The earlier faulting must have occurred well in the past, long ago enough for the old scarp to have been almost completely obliterated prior to formation of the most recent scarp (see Wallace (1977) for examples of compound fault scarps). In several areas adjacent to trench 3 the present scarp has some weak elements of compound morphology (suggesting multiple fault movement), although the evidence is not as compelling as in Wallace's (1977) examples. Evidence in trench 4, about $5 \mathrm{~km}$ to the north, suggests that this older episode of faulting occurred about $150 \mathrm{ka}$ ago. The older episode of faulting occurred all along the northern half of the fault zone, but the offset was relatively small, perhaps 1-2 $\mathrm{m}$ at the most (see section on "Geologic Investigations" of trench 4).

A noteworthy aspect of soil $R$, which is on unit 14 in the trench, is that some of its development occurred prior to burial by unit 13, but that further development only continued where it was not buried (that is, east of $10 \mathrm{~m}$ from the trench headwall, pl. 1C). In these places, soil $\mathrm{R}$ is particularly well developed, having very strong ped structure and advanced calcium carbonate morphology (stage III, $\mathrm{K}$ horizon). This soil is unique in that it persists as coherent slump blocks within the colluvium (unit 2) derived from the fault scarp (12.5-15 m from the headwall, pl. 1C).

The faults in trench $3(13-15.7 \mathrm{~m}$ from the headwall, pl. 1C) bound a $2.5-\mathrm{m}$-wide tilted graben block formed in units 9 and 10 that is filled by young colluvium and blocks of older material. The eastern of the two 
TABLE 8.-Laboratory data and field description for soil $O$, profile T3-10, trench 3, La Jencia fault LABORATORY DATA

[Grain-size analyses of noncalcareous soil fraction in percent; vc, very coarse; c, coarse; m, medium; f, fine; vf, very fine; $\mu \mathrm{m}$, micrometers; <, less than; >, greater than. Laboratory analyses by Donald Cheney, U.S. Geological Survey]

\begin{tabular}{|c|c|c|c|c|c|c|c|c|c|c|c|c|c|c|c|c|}
\hline \multirow{3}{*}{\multicolumn{3}{|c|}{$\begin{array}{l}\text { Grain-size classes- } \\
\text { Grain-size categories } \\
\text { Grain sizes }\end{array}$}} & \multicolumn{3}{|c|}{$<2 \mathrm{~mm}$ fraction } & \multicolumn{5}{|c|}{ Sand $(\mathrm{mm})$} & \multicolumn{2}{|c|}{ Silt $(\mu \mathrm{m})$} & \multicolumn{2}{|c|}{ Clay $(\mu \mathrm{m})$} & \multicolumn{2}{|c|}{ Whole sample } \\
\hline & & & Sand & Silt & Clay & ve & c & $\mathrm{m}$ & $f$ & vf & c & $\mathrm{f}$ & c & $\mathrm{f}$ & & \\
\hline & & & $(2.0-$ & $(0.05-$ & $(<0.002)$ & $(2-1)$ & $(1-0.5)$ & $10.5^{-}$ & $(0.25-$ & $10.1-$ & $(50-20)$ & $(20-2)$ & $(2-0.5)$ & $(<0.5)$ & $(<2 \mathrm{~mm})$ & $(>2 \mathrm{~mm}$ \\
\hline $\begin{array}{l}\text { Sample } \\
\text { No. }\end{array}$ & $\begin{array}{l}\text { Depth } \\
(\mathrm{cm})\end{array}$ & $\begin{array}{l}\text { Horizon or } \\
\text { subhorizon }\end{array}$ & $0.05)$ & $0.002)$ & & & & $0.25)$ & $0.1)$ & $0.05)$ & & & & & & \\
\hline T3-10a-- & $0-8 \cdots$ & $8 \mathrm{~A} \cdots \cdots$ & 65.5 & 23.5 & 11.0 & 6.2 & 11.0 & 13.7 & 17.9 & 16.7 & 15.8 & 7.7 & 3.3 & 6.7 & 91.7 & 8.3 \\
\hline T3-10b-- & $8-21-\cdots$ & $8 B 1 t-\ldots$ & 50.2 & 19.8 & 30.0 & 4.2 & 7.7 & 10.5 & 13.8 & 14.0 & 12.1 & 7.7 & 5.4 & 24.6 & 96.1 & 3.9 \\
\hline T3-10c-- & $21-34--$ & $8 B 21$ tca-- & 54.2 & 20.0 & 25.8 & 5.9 & 10.0 & 11.6 & 13.6 & 13.1 & 11.3 & 8.7 & 7.6 & 18.2 & 92.7 & 7.3 \\
\hline T3-10d-- & $34-46--$ & 8B22tca-- & 52.0 & 17.8 & 30.2 & 4.8 & 10.0 & 13.5 & 15.5 & 8.2 & 9.3 & 8.5 & 5.3 & 24.9 & 86.6 & 13.4 \\
\hline T3 $10 \mathrm{e}^{--}$ & $46-59--$ & 8B23tca--- & 54.8 & 16.2 & 29.0 & 6.0 & 9.7 & 13.4 & 16.3 & 9.4 & 8.4 & 7.8 & 6.4 & 22.6 & 92.3 & 7.7 \\
\hline T3-10f-- & $59-80--$ & 8B3tca-- - & 62.0 & 14.8 & 23.2 & 5.4 & 9.2 & 14.7 & 20.6 & 12.1 & 8.0 & 6.8 & 4.8 & 18.4 & 92.4 & 7.6 \\
\hline T $3-10 \mathrm{~g}--$ & $80-100+$ & $9 K 2 \cdots \cdots$ & 59.3 & 20.3 & 20.4 & 4.2 & 10.1 & 14.8 & 18.4 & 11.8 & 9.0 & 11.3 & 8.6 & 11.8 & 95.2 & 4.8 \\
\hline
\end{tabular}

[Grain-gize analyses of gravel fraction, organic-matter content, and calcium carbonate content in percent; bulk density in g/cm ${ }^{3}$; f, fine; m, medium; c, coarse; <, less than; >, greater than; n.d., not determined; Do., ditto. Laboratory analysee by Donald Cheney, U.S. Geological Surveyl

\begin{tabular}{|c|c|c|c|c|c|c|c|c|c|c|}
\hline \multirow[b]{2}{*}{$\begin{array}{l}\text { Grain-size categories } \\
\text { Grain sizes (mm)-.-- } \\
\text { Sample } \\
\quad \text { No. }\end{array}$} & \multicolumn{3}{|c|}{ Gravel $(>2 \mathrm{~mm})$} & \multirow[b]{2}{*}{$\begin{array}{l}\text { Organic } \\
\text { matter }\end{array}$} & \multirow[b]{2}{*}{${ }^{\ddagger} \mathrm{pH}$} & \multicolumn{2}{|c|}{ Bulk density } & \multicolumn{2}{|c|}{$\mathrm{CaCO}_{3}$} & \multirow[b]{2}{*}{ Texture } \\
\hline & $\frac{f}{(2-19)}$ & $\frac{\mathrm{m}}{(19-76)}$ & $\frac{c}{(>76)}$ & & & $<2 \mathrm{~mm}$ & $\begin{array}{l}\text { Whole } \\
\text { sample }\end{array}$ & $<2 \mathrm{~mm}$ & $\begin{array}{l}\text { Whole } \\
\text { sample }\end{array}$ & \\
\hline $\begin{array}{l}\text { T3-10a- } \\
\text { T3-10b- } \\
\text { T3-10 } \mathrm{c}-\cdots \\
\text { T3-10 d- } \\
\text { T3-10e- } \\
\text { T3-10 } \mathrm{f}-\cdots \\
\text { T3-10 }\end{array}$ & $\begin{array}{r}100.0 \\
100.0 \\
100.0 \\
84.0 \\
100.0 \\
100.0 \\
100.0\end{array}$ & $\begin{array}{r}0.0 \\
.0 \\
.0 \\
16.0 \\
.0 \\
.0 \\
.0\end{array}$ & $\begin{array}{l}0.0 \\
.0 \\
.0 \\
.0 \\
.0 \\
.0 \\
.0\end{array}$ & $\begin{array}{l}\text { n.d. } \\
\text { n.d. } \\
\text { n.d. } \\
\text { n.d. } \\
\text { n.d. } \\
\text { n.d. } \\
\text { n.d. }\end{array}$ & $\begin{array}{l}8.05 \\
8.2 \\
8.5 \\
8.7 \\
8.6 \\
\text { n.d. } \\
8.4\end{array}$ & $\begin{array}{l}* 1.5 \\
1.54 \\
1.56 \\
1.59 \\
1.78 \\
1.75 \\
1.54\end{array}$ & $\begin{array}{c}* 1.6 \\
1.58 \\
1.64 \\
1.73 \\
1.85 \\
1.82 \\
1.59\end{array}$ & $\begin{array}{r}0.2 \\
.3 \\
4.7 \\
3.9 \\
4.1 \\
3.0 \\
45.4\end{array}$ & $\begin{array}{r}0.2 \\
.3 \\
4.4 \\
3.4 \\
3.8 \\
2.8 \\
43.2\end{array}$ & $\begin{array}{l}\text { Sandy loam. } \\
\text { Sandy clay loam. } \\
\text { Do. } \\
\text { Do. } \\
\text { Do. } \\
\text { Sandy clay loam minus. } \\
\text { Do. }\end{array}$ \\
\hline
\end{tabular}

${ }_{*}^{*}$ Values of $\mathrm{pH}$ measured in paste consisting of 1 part soil and 2.5 parts water.

* Estimated value. 
FIELD DESCRIPTION

[n.d., no data; Do., ditto; see table 1 for abbrevations]

SOIL PROFILE: T3-10, soil 0 , trench 3.

DESCRIBED BY: M. N. Machette and D. J. Lidke.

DATE: May 10, 1979.

PARENT MATERIAL: Eolian deposit (unit 8) on piedmont-slope deposit (unit 9).

AGE: Middle Pleistocene (units 8 and 9 ).

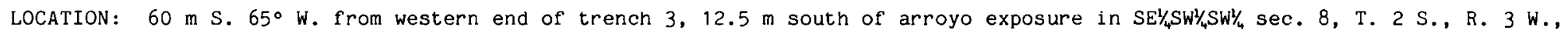
Magdalena 15-minute quadrangle.

GEOGRAPHICAL LANDSCAPE: Piedmont slope between Magdalena Mountains and La Jencia Creek.

ELEVATION: $1,890 \mathrm{~m}$ SLOPE: $1^{\circ}$ ASPECT: East-northeast EROSION: Slight.

CLIMATE: Semiarid: estimated mean annual temperature, $12{ }^{\circ} \mathrm{C}$; mean-annual precipitation, $27 \mathrm{~cm}$.

VEGETATION: Sparse short grasses, cholla, and yucca (rangeland).

REMARKS: Soil exposed in hand-dug pit; stripped from surface near scarp crest at western end of trench 3.

\begin{tabular}{|c|c|c|c|c|c|c|c|c|c|}
\hline $\begin{array}{l}\text { Sample } \\
\text { No. }\end{array}$ & $\begin{array}{l}\text { Depth } \\
(\mathrm{cm})\end{array}$ & Horizon & Color & Texture & Structure & $\begin{array}{l}\text { Consist- } \\
\text { ence }\end{array}$ & $\begin{array}{l}\text { Clay } \\
\text { films }\end{array}$ & $\mathrm{CaCO}_{3}$ & Comments \\
\hline T3-10a-- & $0-8----$ & $8 \mathrm{~A}-----$ & $7.5 \mathrm{YR} 4 / 4 \mathrm{~d}-$ & SaL---- & $\begin{array}{l}\text { mmpl to } \\
\text { sg. }\end{array}$ & ss, & n.d.-- & None. & \\
\hline T3-10b-- & $8-21---$ & $8 \mathrm{~B} 1 \mathrm{t}---$ & $5 \underline{Y R} 4 / 6 \mathrm{~d}---$ & SaCL--- & $\begin{array}{l}\text { mmsab to } \\
\text { wf sab. }\end{array}$ & $\mathrm{ms}, \mathrm{mp}$ & n.d.-- & None. & \\
\hline T3-10c-- & $21-34--$ & $8 \mathrm{~B} 21 \mathrm{tca}$ & 6 YR5/6d--- & SaCL--- & $\begin{array}{l}\text { mesab to } \\
\text { wf sab. }\end{array}$ & $\begin{array}{l}\mathrm{ms}(+) \\
\mathrm{mp}(+)\end{array}$ & n.d.-- & $\begin{array}{l}\text { stg } I \text { and } \\
\text { W stg II. }\end{array}$ & \\
\hline T3-10d-- & $34-46--$ & $8 \mathrm{~B} 22 \mathrm{tca}$ & 6YR5/6d--- & SaCL--- & $\begin{array}{l}\text { mesab to } \\
\text { mmsab. }\end{array}$ & $\begin{array}{l}\mathrm{ms}(+) \\
\quad \mathrm{p}(-)\end{array}$ & n.d.-- & m stg II- & $\begin{array}{l}\text { Carbonate nodules less than } 0.5 \mathrm{~cm} \text {; slightly } \\
\text { redder than } 8 \mathrm{~B} 21 \text { tca subhorizon. }\end{array}$ \\
\hline T3-10e-- & $46-59--$ & $8 \mathrm{~B} 23 \mathrm{tca}$ & 6 YR5/6.5d- & SaCL--- & mmsab--- & $\mathrm{ms}, \mathrm{mp}$ & n.d.-- & --Do. --- & \\
\hline T3-10 -- & $59-80--$ & 8B3tca- & $7.5 \mathrm{YR} 5 / 6 \mathrm{~d}-$ & $\operatorname{SaCL}(-)$ & $\begin{array}{l}\text { mmsab to } \\
\text { wfsab. }\end{array}$ & $\stackrel{\mathrm{ms}}{\mathrm{mp}(-)}$ & n.d.-- & ---Do.--- & \\
\hline $\mathrm{T} 3-10 \mathrm{~g}--$ & $80-100+$ & $9 \mathrm{~K} 2 \cdots-\cdots$ & $\begin{array}{l}7.5 Y R 8 / 2 \mathrm{~d} \\
\text { to white. }\end{array}$ & $\operatorname{SaCL}(-)$ & $\begin{array}{c}\text { wmsab to } \\
\text { wfsab } \\
\text { and } \mathrm{m} .\end{array}$ & ss,sp. & n.d.-- & s stg III & $\begin{array}{l}\text { Structure scpl to smpl where exposed to } \\
\text { surface weathering. }\end{array}$ \\
\hline
\end{tabular}


bounding faults places the basal part of soil $O$ (9Cca horizon) and upper part of soil $\mathrm{P}$ (10Bca horizon) in contact with the buried upper part of soil $\mathrm{O}(8 \mathrm{~B} 2 \mathrm{tca}, 9 \mathrm{~K} 2$, and 9 Cca horizons). This fault has at least $3 / 4 \mathrm{~m}$ of offset, down to the west (antithetic to the main fault). On the west-bounding fault, the $10 \mathrm{Bca}$ horizon of soil $\mathrm{P}$ is downdropped 3.6-3.8 m, which places it in contact with one of the oldest units of the trench, the 16Cca horizon (basal part of soil S, pl. 1C). Within the graben, units 9 and 10 are buried by a jumbled mass of collapse and slump blocks consisting mostly of the $14 \mathrm{Btca}-15 \mathrm{Bt}$ horizons of soil $R$ and isolated blocks of the 10Bca horizon of soil $P$. The slump blocks are surrounded by fine-grained sandy colluvium (units 3-6) which was derived from a mixture of material eroded from the fault scarp and eolian sand. Unit 6, the basal unit of colluvium, has a weak accumulation of organic matter in its upper part (6A horizon, soil N). The time necessary for the $6 \mathrm{~A}$-horizon organic matter to form may have been provided by a fault scarp having a vertical free face that initially resisted erosion because it was supported by soil R. Ponding and deposition of eolian sand in the graben probably accelerated formation of the $6 \mathrm{~A}$ horizon.

Unit 8 is not present within the graben, and the $9 \mathrm{Bca}$ horizon of soil $O$ is thinner here than on the downdropped block, suggesting that these horizons were partly eroded (as previously noted) prior to development of the graben. However, soil R (units 14-15) supported a prominent scarp and supplied the bulk of the grabenfilling material during subsequent degradation of the scarp. Based on the geometry and thickness of horizons of soil $O$ in trench 3 , the scarp on the eastern side of the graben must have been about $2 / 3 \mathrm{~m}$ high (facing east) and separated the top of the $8 \mathrm{~B} 2 \mathrm{t}$ horizon on the east from the downdropped, eroded surface of the $9 \mathrm{Cca}$ horizon. Thus, the east-bounding fault of the graben has had at least two movements that record a reversal of direction of faulting from normal to antithetic. The net offset of unit 9 cannot be determined because its base is not exposed east of the fault at $15.5 \mathrm{~m}$ from the headwall, but at least $1 \mathrm{~m}$ of net down-to-the-west offset has occurred on this fault.

The main episode of faulting that formed the graben also formed the present scarp at trench 3 . Most of the movement during this fault event was on the normal fault at $13.2 \mathrm{~m}$ from the trench headwall (pl. 1C). The fault formed a 3.6- to 3.8-m-high scarp, as estimated from the difference in altitude between the base of the $6 \mathrm{Cn}$ horizon and the projection of the stable part of the upthrown surface (eroded surface of soil 0 ). As previously discussed, movement on the antithetic fault produced a 2/3-m-high scarp that bounded the eastern side of the graben; thus, about $3 \mathrm{~m}$ of net throw occurred during the most recent faulting at trench 3 . The net throw on the top of unit 8 across the zone of faulting is greater, approximately $5.5 \mathrm{~m}$, because it reflects at least two episodes of fault movement. Of the $5.5 \mathrm{~m}$, about $1.25 \mathrm{~m}$ is attributable to a gentle monoclinal warp in unit 8 at the western edge of the downdropped block (15.5-24 $\mathrm{m}$ from the headwall). Thus, there appears to be about $4.25 \mathrm{~m}$ of net tectonic offset of soil $\mathrm{O}$ (units 8-10) on the faults exposed in trench 3.

The youngest fault movement at trench 3 is responsible for most of the height of the present fault scarp. The degradation of this scarp produced a depositional wedge of scarp colluvium (units 1-6). Analyses of both the scarp's morphology (discussed in the section on "Fault-Scarp Investigations") and the nature and distribution of the colluvium help to document the timing of the most recent faulting at trench 3.

Burial of soil O (8B2t-9Cca horizons) by the main body of colluvium (unit 2) effectively stopped the formation of soil $\mathrm{O}$. By assessing the difference in development between the surface soil $O$ (profile T3-10, table 8) on the upthrown block and its buried counterpart on the downdropped block (east of $15.5 \mathrm{~m}$ from the headwall, pl. 1C), the timing of the last fault movement could, in theory, be determined; this is the same approach used in trench 1 . However, soil $O$ is so well developed and its age so poorly constrained that this approach would only indicate that the most recent episode of faulting was much closer to the present than to the age of unit 8 (the youngest faulted deposit). Further evaluation of the buried and relict soils, other than to note that they are very similar, is thus of little use in the consideration of fault timing and, therefore, is not pertinent to the following discussion.

At trench 3, the development of soil $M$ on scarp colluvium provides the most discriminating evidence for the timing of recent fault movements. As at trenches 1 and 2, two types of colluvium were noted. Units 3-6, present from 12.3 to $15.5 \mathrm{~m}$ from the headwall of trench 3 (pl. 1C), are rapidly emplaced graben-filling colluvium. This colluvium was derived from both the initial gravitational collapse of the free face of the scarp and from subsequent erosion of the surface of soil $R$. The upper colluvium ( $\mathrm{Cn}$ horizons of units 1 and 2) forms a more homogeneous yet laterally variable wedge, deposited after the scarp was reduced enough to be dominated by wash-controlled processes.

Four composite profiles of soil $\mathrm{M}$ and the underlying buried soil $\mathrm{O}$ were described and sampled to characterize postfault soil formation and to investigate the lateral variations in the development of soil $M$ that result from slope position and textural changes in parent material. These four soil profiles are $53.0 \mathrm{~m}$ (profile T3-12), $41.6 \mathrm{~m}$ (profile T3-14), $30.3 \mathrm{~m}$ (profile T3-16), and $18.0 \mathrm{~m}$ 
(profile T3-18) from the headwall of the trench (pl. 1C). Profile T3-14 (table 9), judged in the field to be most representative of the soil on younger colluvium, was described in detail and sampled for complete laboratory characterization (table 9). Profiles T3-12, T3-16, and T3-18 were described in varying degrees of detail and sampled for partial laboratory analysis.

Profile T3-14 has a thin layer of young, unweathered colluvium (unit $1, \mathrm{Cn}$ horizon) that overlies a moderately developed soil (soil M) on colluvium about $1 \mathrm{~m}$ thick (unit 2). The soil's composite Bt horizon is $66 \mathrm{~cm}$ thick and has a maximum of 16.6 percent clay in the $2 \mathrm{~B} 21$ tb subhorizon (table 10). Under the Bt horizon is a $2 \mathrm{~B} 3 \mathrm{cab}$ subhorizon that shows little evidence of pedogenic clay accumulation; this subhorizon probably has about the same clay content as the initial parent material (unit 2). The 2B3cab subhorizon has 8 percent clay, whereas the overlying unweathered colluvium (Cn horizon, unit 1) has 7 percent clay (table 10); thus, for comparison, I consider that units 1 and 2 initially had 8 percent clay.

On the basis of both measured and estimated percent clay, the calculated total clay content for the B horizon of soil $\mathrm{M}$ (profile T3-14) is $21.0 \mathrm{~g} / \mathrm{cm}^{2}$ (table 10). This amount consists of $12.7 \mathrm{~g}$ of primary clay (initially present in the parent material) and $8.3 \mathrm{~g}$ of secondary clay (accumulated after deposition of the parent material). The secondary clay can accumulate from in-place weathering of minerals in the soil parent material or result from translocation of clay in overlying materials. Clay that is redistributed within the parent material is not considered as a secondary accumulation.

Soil $\mathrm{M}$ has about $8.3 \mathrm{~g} / \mathrm{cm}^{2}$ of secondary clay. For comparison, at trench 1 to the south, soil $\mathrm{E}$ has about $1.1 \mathrm{~g} / \mathrm{cm}^{2}$ of secondary clay (table 1 ); this amount corresponds to a clay-accumulation rate of $0.18 \pm 0.03$ $\mathrm{g} / \mathrm{cm}^{2} / \mathrm{ka}$ based on an age of about $6 \pm 1 \mathrm{ka}$ for soil $\mathrm{E}$ (see the section on "Geologic Investigations" of trench 1 for a discussion of the age of soil E). Slightly more rain falls now at trench-site 1 than at trench-site 3 $(30 \mathrm{~cm}$ versus $27 \mathrm{~cm}$ ); this additional moisture must cause faster translocation of clay into the soil at trenchsite 1 . However, trench-site 3 , in a wind gap north of the Magdalena Mountains (a major orographic barrier to eastward transport of dust), receives substantially more airborne material than at trench-site 1 . Thus, a clay-accumulation rate for trench 3 based on the midHolocene soil E may not be valid, because there are substantial environmental differences and uncertainties in the actual influx rate of dust.

An additional complication is that the abovementioned accumulation rate (derived from trench-site 1) is for a Holocene soil; accumulation rates in the late Pleistocene probably were different. The presence of a large system of lakes on the Plains of San Agustin (about $30 \mathrm{~km}$ west of the La Jencia basin) during the late Pleistocene suggests that the climate was wetter and (or) cooler and that the vegetative cover was greater than in the Holocene (see discussion of paleoenvironmental conditions by Markgraf and others, 1984). These factors would have decreased the potential amount of airborne material but enhanced the entrapment and translocation of dust into soils. I believe that the combination of these factors points toward higher dust-fall rates in the Holocene. This interpretation is supported by calcium carbonate accumulation rates in New Mexico (Bachman and Machette, 1977, p. 132, fig. 8; Machette, 1985) that were substantially higher in the Holocene than during longer spans of the late Pleistocene.

Not enough is known about the previous climates, dust-source areas, and circulation patterns of air masses to more than estimate clay-accumulation rates within broad limits. For soil $\mathbf{M}$ at trench $3, \mathbf{I}$ have assumed that the average clay-accumulation rate for the late Quaternary (Holocene and late Pleistocene) is $0.23 \pm 0.04$ $\mathrm{g} / \mathrm{cm}^{2} / \mathrm{ka}$. This value is 25 percent higher than the rate for Holocene soils at trench 1, primarily because trenchsite 3 is dustier and has eolian deposits, whereas trenchsite 1 does not have eolian deposits. At this rate, the $8.3 \mathrm{~g}$ of secondary clay present in soil $\mathrm{M}$ (profile T3-14) would have accumulated during about 36,000 years $(+7,700$ years, $-5,300$ years), or over a range of 30,700 to 43,700 years ago. This age range should be considered strictly as an estimate; the accumulation rate used to derive it is subject to poorly understood temporal, local, and regional variations.

Unlike the two southern trenches, trench-site 3 lies within an area of pedocals (calcareous soils), and thus the carbonate content of soils at trench 3 can also be used to make age estimates. Four profiles from soil $\mathbf{M}$ were analyzed for carbonate content and grain size (fig. 8). The soil profiles were described and sampled along an east-west transect on the lower part of the scarp (pl. 1C). The profiles all have a thin layer of unweathered colluvium (Cn horizon) that rests unconformably on soil $M$, which is developed on unit 2 (the main body of colluvium, fig. 7). The colluvium is a slightly pebbly to gravelly sandy loam containing generally less than 10 percent gravel. However colluvium at the midslope of the scarp (profile T3-18, fig. 7) contains as much as 35 percent coarse fragments. The colluvium coarsens toward the former free face of the scarp (about $13.2 \mathrm{~m}$ from the headwall, pl. 1C), source of much of unit 2 . The colluvium thickens from $80 \mathrm{~cm}$ near the toe of the scarp to a maximum of $125 \mathrm{~cm}$ near the site of soil-profile T3-16, at $30.3 \mathrm{~m}$ from the headwall (pl. 1C and fig. 8). Upslope from the main fault, the colluvium is $40 \mathrm{~cm}$ or less in thickness and fills slight irregularities on the eroded surface of older units. 
TABLE 9.-Laboratory data and field description for soils $M$ and 0 , profile T3-14, trench 3, La Jencia fault LABORATORY DATA

[Grain-size analyses of noncalcareous soil fraction in percent; vc, very coarse; c, coarse; m, medium; f, fine; vf, very fine; $\mu \mathrm{m}$, micrometers; <, less than; >, greater than. Laboratory analyses by Donald Cheney, U.S. Geological Survey]

\begin{tabular}{|c|c|c|c|c|c|c|c|c|c|c|c|c|c|c|c|c|}
\hline \multirow{2}{*}{\multicolumn{3}{|c|}{$\begin{array}{l}\text { Grain-size classes- } \\
\text { Grain-size categories- }\end{array}$}} & \multicolumn{3}{|c|}{$<2-\mathrm{mm}$ fraction } & \multicolumn{5}{|c|}{ Sand $(\mathrm{mm})$} & \multicolumn{2}{|c|}{ Silt $(\mu \mathrm{m})$} & \multicolumn{2}{|c|}{ Clay $(\mu \mathrm{m})$} & \multicolumn{2}{|c|}{ Whole sample } \\
\hline & & & Sand & Silt & Clay & ve & c & $\mathrm{m}$ & $\mathrm{f}$ & $v f$ & $\mathrm{c}$ & f & c & $f$ & & \\
\hline Grain size & $s(m m)---$ & -........- & $(2.0-$ & $(0.05-$ & $(<0.002)$ & $(2-1)$ & $(1-0.5)$ & $\left(0.5^{-}\right.$ & $(0.25-$ & $(0.1-$ & $(50-20)$ & $(20-2)$ & $(2-0.5)$ & $(<0.5)$ & $(<2 m m)$ & $(>2 \mathrm{~mm}$ \\
\hline $\begin{array}{c}\text { Sample } \\
\text { No. }\end{array}$ & $\begin{array}{l}\text { Depth } \\
(\mathrm{cm})\end{array}$ & $\begin{array}{l}\text { Horizon or } \\
\text { subhorizon }\end{array}$ & $0.05)$ & 0.002 & & & & $0.25)$ & $0.1)$ & $0.05)$ & & & & & & \\
\hline T3-14a-- & $0-5-\cdots$ & $\mathrm{Cn} \cdots$ & 71.1 & 21.1 & 7.9 & 9.6 & 14.8 & 15.2 & 15.9 & 15.5 & 14.2 & 6.9 & 3.8 & 4.1 & 94.0 & 6.0 \\
\hline T3-14b-- & $5-13---$ & $2 \mathrm{Ab}^{-\cdots \cdots}$ & 66.5 & 21.6 & 11.9 & 5.4 & 12.3 & 15.5 & 19.2 & 14.1 & 14.2 & 7.4 & 4.3 & 7.6 & 93.1 & 6.9 \\
\hline T3-14c-- & $13-24-\cdots$ & $2 \mathrm{~B} 1 \mathrm{tb}-\cdots--$ & 61.5 & 20.6 & 17.9 & 5.0 & 11.8 & 14.8 & 16.2 & 13.7 & 14.2 & 6.4 & 3.2 & 14.7 & 93.0 & 7.0 \\
\hline T3-14d-- & $24-58-\cdots$ & 2B22tb---- & 62.7 & $21 \cdot 3$ & 16.0 & 7.8 & 12.8 & 13.7 & 15.2 & 13.2 & 15.1 & 6.2 & 3.3 & 12.7 & 94.7 & 5.3 \\
\hline T3-14e-- & $58-79-\cdots$ & 2B23tcab-- & 47.3 & 40.3 & 12.4 & 6.4 & 9.4 & 10.0 & 11.4 & 10.1 & 17.7 & 22.6 & 8.4 & 4.0 & 93.0 & $7: 0$ \\
\hline$T 3-14 \mathrm{f}--$ & 79-96--- & 2B3cab---- & 56.0 & 34.8 & 9.2 & 4.3 & 8.6 & 12.1 & 16.0 & 15.0 & 18.7 & 15.9 & 6.0 & 3.2 & 91.2 & 8.8 \\
\hline T3-14g-- & $96-127--$ & $8 B 2 t c a b---$ & 43.2 & 16.1 & 40.7 & 4.1 & 7.6 & 11.0 & 12.1 & 8.4 & 9.3 & 6.8 & 6.7 & 34.0 & 97.2 & 2.8 \\
\hline T3-14h-- & $127-166-$ & $9 \mathrm{~K} 2 \mathrm{~b}-\cdots-$ & 51.0 & 24.4 & 24.6 & 4.6 & 10.1 & 12.9 & 13.4 & 10.0 & 10.0 & 10.0 & 14.4 & 9.1 & 97.6 & 2.4 \\
\hline T3-14i-- & $106-186-$ & $9 \times 3 \mathrm{~b}-\cdots$ & 47.7 & 34.6 & 13.1 & 5.6 & 9.8 & 12.9 & 15.2 & 8.8 & 14.4 & 20.2 & 7.9 & 5.2 & 91.3 & 8.7 \\
\hline T3-14j-- & $186-242-$ & 9 Ccab---.- & 75.8 & 22.1 & 2.1 & 6.9 & 15.4 & 23.0 & 18.7 & 11.8 & 11.2 & 10.9 & 1.5 & 0.6 & 90.0 & 10.0 \\
\hline
\end{tabular}

[Grain-size analyses of gravel fraction, organic-matter content, and calcium carbonate content in percent; bulk density in g/cm ${ }^{3}$; f, fine; m, medium; c, coarse; <, leas than; >, greater than; n.d., not determined; Do., ditto. Laboratory analysea by Donald Cheney, U.S. Geological Survey]

\begin{tabular}{|c|c|c|c|c|c|c|c|c|c|c|}
\hline \multirow[b]{2}{*}{$\begin{array}{l}\text { Grain-size categories } \\
\text { Grain sizes (mm)---- } \\
\text { Sample } \\
\quad \text { No. }\end{array}$} & \multicolumn{3}{|c|}{ Gravel (>2 mm) } & \multirow[b]{2}{*}{$\begin{array}{l}\text { Organic } \\
\text { matter }\end{array}$} & \multirow[b]{2}{*}{${ }^{\ddagger} \mathrm{pH}$} & \multicolumn{2}{|c|}{ Bulk density } & \multicolumn{2}{|c|}{$\mathrm{CaCO}_{3}$} & \multirow[b]{2}{*}{ Texture } \\
\hline & $\frac{\mathrm{f}}{(2-19)}$ & $\frac{m}{(19-76)}$ & $\frac{c}{(>76)}$ & & & $<2 \mathrm{~mm}$ & $\begin{array}{l}\text { Whole } \\
\text { sample }\end{array}$ & $<2 \mathrm{~mm}$ & $\begin{array}{l}\text { Whole } \\
\text { sample }\end{array}$ & \\
\hline 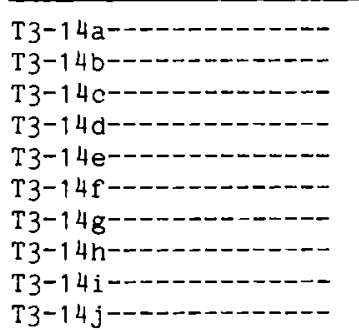 & $\begin{array}{r}100.0 \\
100.0 \\
100.0 \\
100.0 \\
100.0 \\
100.0 \\
100.0 \\
100.0 \\
88.0 \\
100.0\end{array}$ & $\begin{array}{r}0.0 \\
.0 \\
.0 \\
.0 \\
.0 \\
.0 \\
.0 \\
.0 \\
12.0 \\
.0\end{array}$ & $\begin{array}{l}0.0 \\
.0 \\
.0 \\
.0 \\
.0 \\
.0 \\
.0 \\
.0 \\
.0 \\
.0\end{array}$ & $\begin{array}{l}\text { n.d. } \\
\text { n.d. } \\
\text { n.d. } \\
\text { n.d. } \\
\text { n.d. } \\
\text { n.d. } \\
\text { n.d. } \\
\text { n.d. } \\
\text { n.d. } \\
\text { n.d. }\end{array}$ & $\begin{array}{l}7.8 \\
7.9 \\
8.3 \\
8.5 \\
8.5 \\
8.8 \\
8.5 \\
8.8 \\
8.8 \\
8.6\end{array}$ & $\begin{array}{r}* 0.53 \\
1.72 \\
1.57 \\
1.74 \\
1.66 \\
1.50 \\
1.71 \\
1.36 \\
*_{1} 1.62 \\
1.59\end{array}$ & $\begin{array}{l}* 1.6 \\
1.79 \\
1.65 \\
1.79 \\
1.73 \\
1.64 \\
1.74 \\
1.39 \\
* 1.75 \\
1.7\end{array}$ & $\begin{array}{r}0.4 \\
.3 \\
.3 \\
1.3 \\
10.1 \\
5.7 \\
2.9 \\
54.0 \\
42.4 \\
5.1\end{array}$ & $\begin{array}{r}0.4 \\
.3 \\
.3 \\
1.2 \\
9.4 \\
5.2 \\
2.8 \\
52.7 \\
36.7 \\
4.6\end{array}$ & $\begin{array}{l}\text { Sandy loam minus. } \\
\text { Sandy loam. } \\
\text { Sandy loam plus. } \\
\text { Do. } \\
\text { Loam. } \\
\text { Sandy loam. } \\
\text { Clay minus. } \\
\text { Sandy clay loam. } \\
\text { Loam minus. } \\
\text { Loamy sand minus. }\end{array}$ \\
\hline
\end{tabular}

* Values of $\mathrm{pH}$ measured in paste consisting of 1 part soil and 2.5 parts water.

*Estimated value. 

soil 0 (units 8 and 9 ), trench 3 .

PARENT MATERIaL: Colluvium (units 1 and 2) over eolian sand (unit 8 ) and alluvium (unit 9 ).

AGE: Holocene (unit 1) and late Pleistocene (unit 2) over middle Pleistocene (units 8 and 9).

LOCATION: South wall of trench $3,41.7 \mathrm{~m}$ east of headwall, SE $1 / 4 \mathrm{SW}^{1 / 4} \mathrm{SW} / 4 \mathrm{sec}, 8, \mathrm{~T}, 2 \mathrm{~S} ., \mathrm{R} .3 \mathrm{~W}$. , Magdalena 15-minute quadrangle.

GEOGRAPHICAL LANDSCAPE: Toe of fault scarp on piedmont slope.

SOIL DEVELOPMENT: Soil M, moderate; soil O, strong.

ELEVATION: $1,885 \mathrm{~m}$ SLOPE: $1-2^{\circ}$ ASPECT: East-northeast EROSION: None.

CLIMATE: Semiarid: estimated mean annual temperature, $12{ }^{\circ} \mathrm{C}$; mean annual precipitation, $27 \mathrm{~cm}$.

VEGETATION: Sparse short grasses, cholla, and yucca (rangeland).

\begin{tabular}{|c|c|c|c|c|c|c|c|c|c|}
\hline $\begin{array}{l}\text { Sample } \\
\text { No. }\end{array}$ & $\begin{array}{l}\text { Depth } \\
(\mathrm{cm})\end{array}$ & Horizon & Color & Texture & Structure & $\begin{array}{l}\text { Consist- } \\
\text { ence }\end{array}$ & $\begin{array}{l}\text { Clay } \\
\text { films }\end{array}$ & $\mathrm{CaCO}_{3}$ & Comments \\
\hline T3-14a--- & $0-5----$ & $\mathrm{Cn}-\cdots-n$ & $10 \underline{Y R} 4 / 3 m---$ & $\operatorname{SaL}(-)$ & sg-n-- & $\begin{array}{l}\text { vss, } \\
\text { po. }\end{array}$ & n.d.-- & None----- & Loose when dry; abrupt, smooth boundary. \\
\hline T3-14b--- & $5-13---$ & $2 A B-----$ & $\mathrm{iOYR} 3 / 3 \mathrm{~m}=-$ & SaL--- & $\begin{array}{l}\text { mmsab to } \\
\text { wfsab. }\end{array}$ & ss, & n.d.--- & None----- & Firm when dry; clear, smooth boundary. \\
\hline T3-14c--- & $13-24--$ & 2B1 tb--- & $9 \underline{Y R} 4.5 / 3 d--$ & $\operatorname{SaL}(+)$ & $\begin{array}{l}\text { mmsab to } \\
\text { wfsab. }\end{array}$ & ss, & n.d.-- & None----- & Clear, smooth boundary. \\
\hline T3-14d--- & $24-58--$ & $2 \mathrm{~B} 22 \mathrm{tb}--$ & $9 \underline{Y} 4.5 / 4 d--$ & $\operatorname{SaL}(+)$ & $\begin{array}{l}\text { mmsab to } \\
\text { mfsab. }\end{array}$ & ss+, & n.d.--- & vw stg I- & Gradual, smooth boundary. \\
\hline T3-14e--- & $58-79--$ & 2B23tcab & $7.5 \underline{Y R} 5.5 / 4 d$ & L-- --- & mmsab--- & ms, & n.d.--- & m stg I-- & $\begin{array}{l}\text { Clear, smooth boundary. Carbonate in } \\
\text { veinlets. }\end{array}$ \\
\hline T3-14f - - & $79-96--$ & 2B 3cab-- & $9 \underline{Y R} 6 / 4 d-\cdots$ & SaL--- & mmsab--- & ms, & n.d. - - & $\begin{array}{l}\mathrm{m} \text { stg } \mathrm{I} \\
\text { and } \mathrm{II}\end{array}$ & $\begin{array}{l}\text { Carbonate nodules less than } 0.5 \mathrm{~cm} \text { in } \\
\text { diameter; clear, smooth boundary. }\end{array}$ \\
\hline T3-14g--- & $96-127-$ & 8B2tcab- & $5 \underline{Y R} 4 / 6 d---$ & $C(-)--$ & $\begin{array}{l}\text { scsab to } \\
\text { sfsab. }\end{array}$ & $\mathrm{s}, \mathrm{p}$ & $n \cdot d \cdot \cdots$ & w stg I-- & $\begin{array}{l}\text { 2.5YR } 4 / 6 \mathrm{~d} \text { clay films; sampled at } 115 \mathrm{~cm} \text {; } \\
\text { abrupt, wavy boundary. }\end{array}$ \\
\hline T3-14h--- & $127-166$ & 9K2b---- & White----- & SaCL-- & $\begin{array}{l}\text { mmsab to } \\
\text { mfsab. }\end{array}$ & $\begin{array}{l}\mathrm{ms} \text {, } \\
\mathrm{mp} \text {. }\end{array}$ & n.d.-- & s stg III & Diffuse, wavy boundary. \\
\hline T3-14i--- & $166-186$ & 9K3b---- & $7.5 \mathrm{YR} 8 / 2 \mathrm{~d}--$ & $L(-)--$ & $\begin{array}{l}\text { minsab } \\
\text { to } s g \text {. }\end{array}$ & ms-, & n.d.-- & $\begin{array}{l}\mathrm{m} \text { stg } \text { III } \\
\text { and } \mathrm{s} \\
\text { stg } \mathrm{II} .\end{array}$ & $\begin{array}{l}\text { Firm carbonate nodules; diffuse, wavy } \\
\text { boundary. }\end{array}$ \\
\hline T3-14j--- & $186-242$ & 9ccab--- & $\begin{array}{c}7.5 \mathrm{YR} 8 / 2 \mathrm{~d} \\
\mathrm{to} 7.5 \mathrm{YR} \\
5.5 / 5 \mathrm{~d} .\end{array}$ & LSa $(-)$ & $s g-\cdots--$ & $\begin{array}{l}\text { vss, } \\
\text { po. }\end{array}$ & n.d. $\cdots$ & w stg II- & $\begin{array}{l}\text { Diffuse carbonate nodules; sampled at } \\
225 \mathrm{~cm} \text {; gradual, smooth boundary. }\end{array}$ \\
\hline No sample & $242+\cdots-$ & 9 Coxb--- & $7.5 \underline{Y R} 5.5 / 5 d$ & $\mathrm{Sa}(+)-$ & $s g-\cdots-$ & so, & n.d. $\cdots$ & None. & \\
\hline
\end{tabular}


TABLE 10.-Clay data for soil $M$ (profile T3-14) on scarp colluvium at trench 3, La Jencia fault

[Percent clay calculated from whole sample; values for parent material estimated from Cn horizon and 2B3cab subhorizon]

\begin{tabular}{|c|c|c|c|c|c|c|c|c|}
\hline $\begin{array}{c}\text { Soil hor izons } \\
\text { and } \\
\text { subhorizons }\end{array}$ & $\begin{array}{c}\text { A } \\
\text { Thickness } \\
(\mathrm{cm})\end{array}$ & \multicolumn{3}{|c|}{ Soil M } & \multicolumn{3}{|c|}{ Parent material } & $\begin{array}{c}\frac{\text { Gain }}{H} \\
\text { Secondary } \\
\text { clay content } \\
\left(\mathrm{g} / \mathrm{cm}^{2} ; \mathrm{D}-\mathrm{G}\right)\end{array}$ \\
\hline $\mathrm{Cn}-\cdots$ & 5 & 7.4 & $\pm_{1.6}$ & 0.6 & 8.0 & 1.6 & 0.6 & 0.0 \\
\hline $2 A D-\cdots-\cdots$ & 8 & 11.1 & 1.79 & 1.6 & 8.0 & 1.65 & 1.1 & .5 \\
\hline 2B22tcab------ & 21 & 11.5 & 1.73 & 4.2 & 8.0 & 1.65 & 2.8 & 1.4 \\
\hline $\begin{array}{l}\text { 2B3cab- } \\
\text { Total }\end{array}$ & $\frac{17}{96}$ & 8.4 & 1.64 & $\frac{2.3}{21.0}$ & 8.0 & 1.65 & $\frac{2.2}{12.7}$ & $\frac{.1}{8.3}$ \\
\hline
\end{tabular}

\pm Estimated value.

The secondary calcium carbonate in soil $\mathrm{M}$ forms fine veinlets (stage I) and small disseminated nodules (stage II) in a matrix of sandy loam. The depth at which it has precipitated generally decreases upslope, toward the steepest part of the scarp. For example, at the site of profile T3-14 (41.6 $\mathrm{m}$ from the headwall, pl. 1C), the top of the 2B23tcab subhorizon is at 58-cm depth, which marks a sharp increase from 1.2 to 9.4 percent carbonate (table 9, fig. 8). Upslope, the top of the uppermost calcic horizon in profiles T3-16 and T3-18 are at 27- and 18-m depths, respectively, showing a marked shallowing of secondary carbonate accumulation in response to slope and position on the scarp. At these sites, the surface slope controls infiltration of surface water and results in less infiltration to shallower depths on the scarp and more and deeper infiltration on the flatter slopes basinward of the scarp.

In the past, occasional infiltration of surface water to depths of more than $1 \mathrm{~m}$ moved calcium carbonate completely through the colluvium (units 1 and 2) and into the $B$ horizon of buried-soil $O$ (unit 8). The irregular distribution of carbonate illustrated in figure 8 shows that some carbonate was added to the $8 \mathrm{~B} 2 \mathrm{t}$ horizon of soil $O$ after it was buried. The upper two subhorizons (8B1tbca and 8B21tbca) have downward decreasing carbonate contents of 4.0 and 2.0 percent, and this carbonate must have accumulated in a Bt horizon that was leached of carbonate before its burial. Conversely, the underlying 8B22tcab subhorizon contained most or all of its present 5.4 percent carbonate prior to burial by unit 2 .

The scarp colluvium was derived almost entirely from surface and buried soils that compose the bulk of the materials in the upthrown block; therefore, the colluvium must have been deposited with some primary carbonate The primary carbonate content of the bulk of the colluvium (unit 2) would normally be measured in the $2 \mathrm{Cn}$ horizon. However, soil $\mathrm{M}$ generally extends through unit 2 , so that in most places the primary carbonate content cannot be directly measured. Where unit 2 is least modified by soil processes (that is, the basal parts of the 2Bca or 2Cca subhorizon), it has 2-3 percent calcium carbonate, and these values must be equal to or be greater than the original carbonate content in unit 2. The colluvium becomes finer grained away from the scarp due to normal processes of transport on decreasing slopes and due to dilution of the colluvium with eolian material near the base of the scarp; these two factors probably caused the colluvium of unit 2 to have a carbonate content that decreases slightly, away from the scarp.

Several assumptions must be made to calculate the content of secondary calcium carbonate in soil $M$. The method of calculation requires values for the unweathered parent material (2Cn) or, less desirably, values based on a model of primary carbonate distribution. Because unit 2 is everywhere modified by soil processes, I use the latter type of data. The model used here assumes that carbonate initially is distributed uniformly through a vertical section of the colluvium but is zoned laterally, being slightly more calcareous near its source at the fault scarp. This model is based on field observations, unpublished analyses of grain size, and the carbonate contents of soil horizons (fig. 8).

The estimated values for percent of primary calcium carbonate in the parent material (table 11) range from 2.0 percent in profile T3-18 to 0.4 percent (leached) near the lower end of the trench (profile T3-12). Additional corrections were made to compensate for preburial and postburial carbonate that accumulated in buriedsoil $\mathrm{O}$ (mainly the $8 \mathrm{Bt} 2 \mathrm{cab}$ horizon). The bulk density of the soil parent material was estimated from the development of soil horizons and from bulk densities measured in unit 1, the unweathered colluvium (Cn horizon) overlying unit 2. Here again, a model based on vertically homogenous, laterally decreasing values of bulk density was used for the calculations (table 11). 


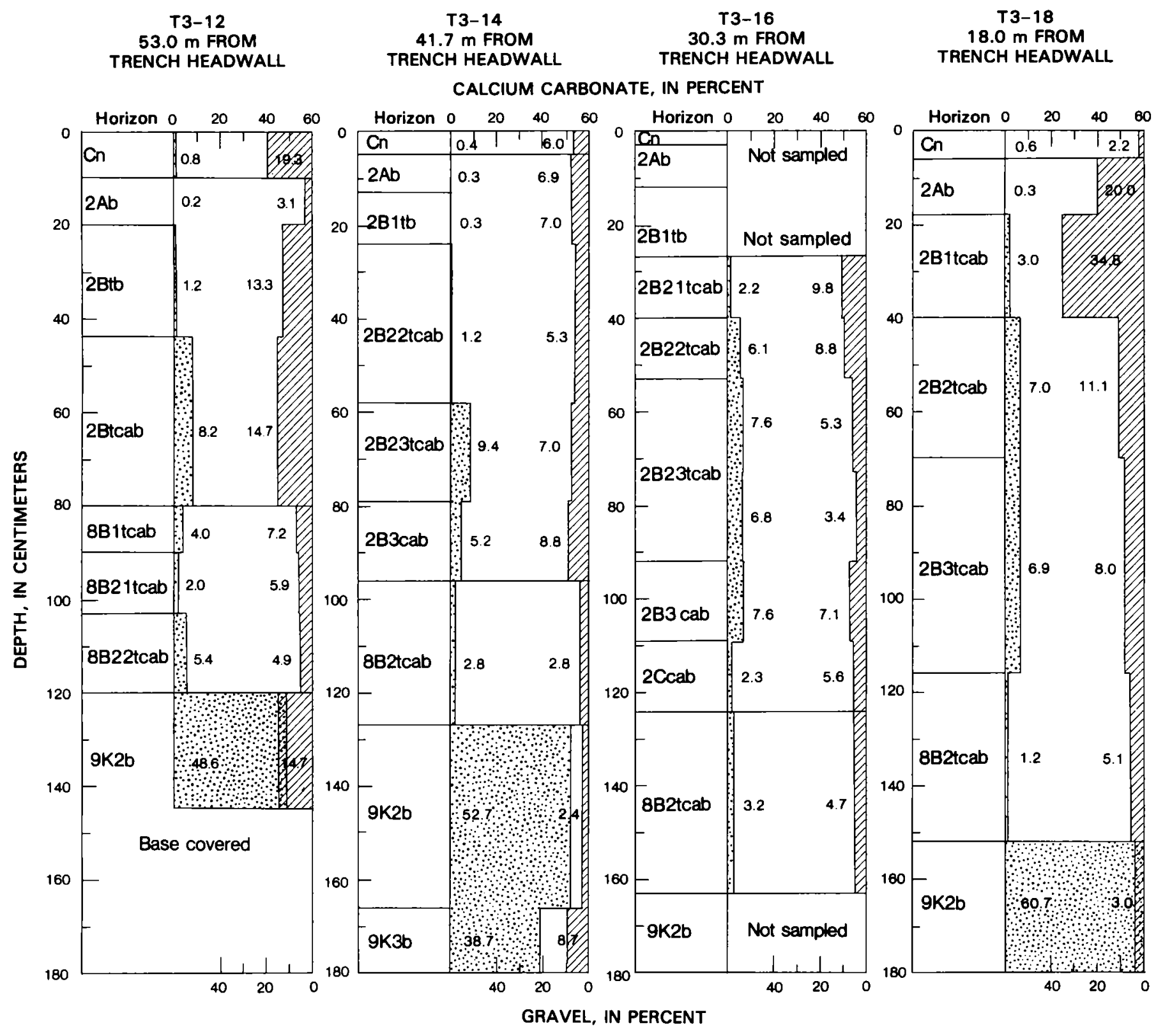

Figure 8.-Profiles of soil $\mathrm{M}$ exposed in trench 3, showing contents of calcium carbonate and gravel. $\mathrm{CaCO}_{3}$, stippled; gravel, line pattern. Soil above unit 8 is on colluvium (units 1-5) derived from fault scarp.

The total carbonate content of the four profiles of soil $M$ was calculated in the same manner as the clay content (table 10). The total carbonate content of a sample is the sum of both primary and secondary carbonate components (table 11); all three values are expressed in weight (grams) of calcium carbonate per unit area (a column of $1-\mathrm{cm}^{2}$ cross-sectional area through the soil).

On the basis of the above model and the data presented in figure 8 , the calculated secondary carbonate content of soil $\mathrm{M}$ averages about $6.7 \mathrm{~g} / \mathrm{cm}^{2}$ and ranges from 5.5 to $7.9 \mathrm{~g} / \mathrm{cm}^{2}$ (table 11). Two of the four soil profiles have carbonate contents that fall within $0.5 \mathrm{~g}$ of the average value; accordingly, a value of $6.7 \pm 0.5 \mathrm{~g} / \mathrm{cm}^{2}$ was used for calculations of the age of soil $M$. It should be noted that on the scarp, soil $M$ (profiles T3-16 and T3-18) has onethird to one-half more secondary carbonate (7.9 and 7.5 g) than it does at the base of the scarp $(6.3$ and $5.5 \mathrm{~g}$, profiles T3-12 and T3-14). In part, this difference reflects the deeper infiltration and subsequent leaching of the upper soil horizons on gentle slopes, as previously noted. 
TABLE 11.-Calcium carbonate data for soil $M$ on fault-scarp colluvium in trench 3, La Jencia fault

[Samples T3-12 at 53.0 m; T3-14 at $41.7 \mathrm{~m} ; \mathrm{T} 3-16$ at $30.3 \mathrm{~m}$; and T3-18 at $18.0 \mathrm{~m}$, respectively, from the headwall of trench 3 . All data are computed on basis of whole sample. CaCO and bulk-density values from model of parent material based on lithologic and stratigraphic data. N.s, not samplod; -, $\mathrm{CaCO}_{3}$ lost from subhorizon. An extra significant digit is carried in the calculations to prevent large errors due to rounding]

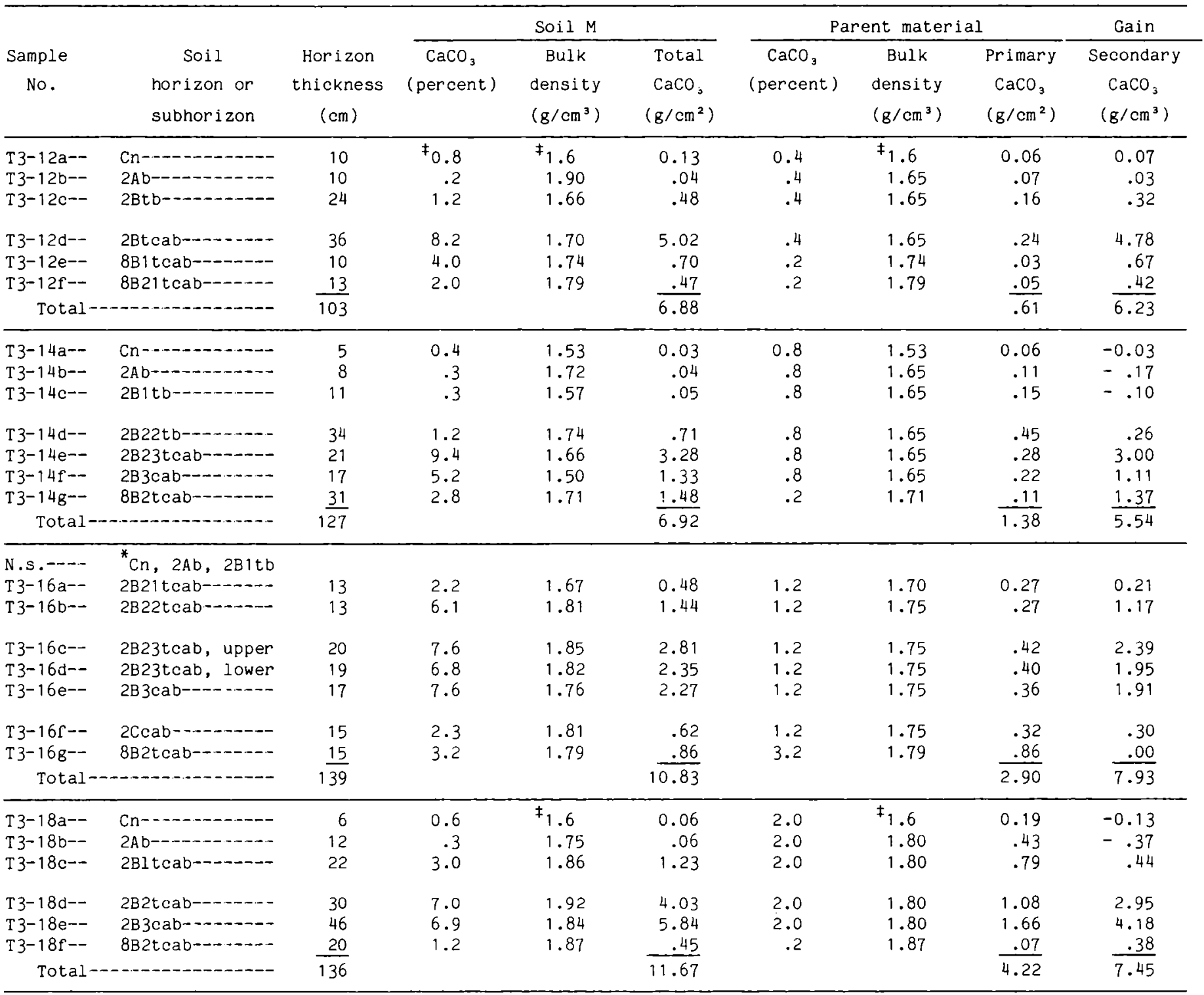

* Estimated value.

*Analyses not performed on noncalareous upper three subhorizons.

In addition, the primary carbonate content in the two soils on the scarp may have been underestimated in the model, because masses of calcareous soil in the colluvium close to the scarp may later have been modified by soil formation; these masses would then be wrongly considered as representing secondary contributions of carbonate.

Tb estimate the age of soil $M$ from its secondary carbonate content, the rate (or range of rates) of carbonate accumulation in the scarp colluvium since its deposition must be known. Bachman and Machette (1977), in a regional study of rates of calcic-soil formation, determined the long-term (that is, $0.5 \mathrm{Ma}$ ) accumulation rates for three areas of New Mexico; two of these rates may apply to this study. Middle Pleistocene calcic soils of the Albuquerque area (mean-annual precipitation of $20.7 \mathrm{~cm}$, U.S. National Oceanic and Atmospheric Administration, 1978) have formed at an average rate of $0.22 \pm 0.02 \mathrm{~g} / \mathrm{cm}^{2} / \mathrm{ka}$, whereas those near Las Cruces (mean-annual precipitation of $20.5 \mathrm{~cm}$, U.S. National Oceanic and Atmospheric Administration, 1978), formed substantially faster at a rate of $0.32 \pm 0.03 \mathrm{~g} / \mathrm{cm}^{2} / \mathrm{ka}$ (Bachman and Machette, 1977). 
Trench-site 3 presently has a semiarid climate and about $27 \mathrm{~cm}$ of annual precipitation, and, at least in the past, had a considerable influx of calcareous dust, two factors that favor high accumulation rates of carbonate. Conversely, this site's proximity to the pedocal-pedalfer boundary (pl. 2) suggests that carbonate may have been lost from local soils during wet (pluvial) phases of the Pleistocene. Also, the rate of influx of calcareous dust during the late Pleistocene may have been low compared to the increased amount of rainfall available; these factors also would have inhibited, to a certain extent, the maximum accumulation of carbonate (Machette, 1985). Again, the problem of determining rate is not easily solved, but a rate can be estimated from patterns of regional soil development and comparison to local soils of equivalent age in the Albuquerque-Belen area of New Mexico. On the basis of such comparisons, the average rate of carbonate accumulation at trench 3 during the late Pleistocene and Holocene was probably about the same as the long-term average at Albuquerque, $0.22 \pm 0.02$ $\mathrm{g} / \mathrm{cm}^{2} / \mathrm{ka}$. Accordingly, rates of $0.20-0.24 \mathrm{~g} / \mathrm{cm}^{2} / \mathrm{ka}$ are used in further calculations of the age of soil $\mathrm{M}$.

Three basic assumptions have been made that are fundamental to estimates of soil age: (1) the model of primary carbonate content accurately reflects the carbonate concentration and distribution in the soil parent material; (2) the average secondary carbonate content, $6.7 \pm 0.5 \mathrm{~g}$, is characteristic of soil $\mathrm{M}$; and (3) the rate of secondary carbonate accumulation, $0.20-0.24 \mathrm{~g} / \mathrm{cm}^{2} / \mathrm{ka}$, is representative of the time span considered. All three assumptions are critical yet poorly constrained; nevertheless, the rates used here are based on a combination of regional, local, and site-specific information. If these assumptions are realistic, a time span of 30,500 years $(+5,500$ years, $-4,700$ years) would have been required to accumulate the secondary carbonate present in soil $\mathbf{M}$.

The two ages for soil $M$ calculated from clay and carbonate data (table 12) are similar, and their estimated ages overlap within concordant error limits. Considering the possibility of temporal, regional, and local variations in both clay and carbonate flux rates, the average of the two age calculations, approximately 33,000 years, provides an estimate that is not likely to be in error by more than about 20 percent $(+6,600$ years, $-5,000$ years). These age and error limits, which I believe are fairly liberal, are hereafter used in this report.

\section{SUMMARY}

The following conclusions can be drawn from the geologic investigations at trench 3 :

1. On the basis of geologic and pedologic data and climatic interpretations, the most recent episode of faulting probably occurred about $33 \mathrm{ka}$ ago and certainly
TABLE 12.-Estimates of soil age calculated from the clay and calcium carbonate contents in soil $M$ on fault-scarp colluvium at trench 3 , La Jencia fault

\begin{tabular}{lccc}
\hline Component & $\begin{array}{c}\text { Content } \\
\left(\mathrm{g} / \mathrm{cm}^{2}\right)\end{array}$ & $\begin{array}{c}\text { Rate of } \\
\text { accumulation } \\
\left(\mathrm{g} / \mathrm{cm}^{2} / \mathrm{ka}\right)\end{array}$ & $\begin{array}{c}\text { Estimated age } \\
(\mathrm{ka}) \text { and (error } \\
\text { limits })\end{array}$ \\
\hline Clay------ 8.3 & $0.23 \pm 0.04$ & $36.0(+7.7,-5.3)$ \\
Carbonate--- $6.7 \pm 0.5$ & $0.22 \pm 0.02$ & $30.5(+5.5,-4.7)$ \\
Average age of two components-- & $33.3(+6.6,-5.0)$ \\
\hline
\end{tabular}

occurred sometime between 28 and $40 \mathrm{ka}$ ago. The most recent faulting produced 3.6 to $3.8 \mathrm{~m}$ of displacement. Soil O, estimated to have formed during the past 300,000 years, has been offset a total of about $5.25 \mathrm{~m}$ across the fault; $1.25 \mathrm{~m}$ of this offset is due to a monoclinal warp. The net offset is the product of two discrete episodes of rupturing.

2. An earlier episode of faulting about $150 \mathrm{ka}$ ago (based on inferences from trench 4) produced a scarp 1 to $2 \mathrm{~m}$ high that was almost completely obliterated prior to the latest fault movement. Erosion, in response to this early episode of faulting, stripped the upper part of soil $O$ about $60 \mathrm{~m}$ back from the upthrown fault block.

3. Five buried soils in the trench and the surface soil on the upthrown fault block record a long history of periodic sedimentation and soil formation, perhaps throughout most of Quaternary time. These soils, which are primarily pedocals, may have been transformed from pedalfers in the past.

\section{TRENCH 4}

\section{SETTING}

Trench-site 4, the northernmost of the four sites, is north of La Jencia Creek on a broad, gentle piedmont slope 1.5-2 km east of the Bear Mountains (fig. 3). The site is about $1 \mathrm{~km}$ south of a windmill and stock tank that are just south of the road to the Gray and Ligon Ranch (NW1/4SW1/4SE1/4 sec. 30, T. 1 S., R. 3 W.; pl. 2). Access to the site was via temporary dirt roads built across a widespread blanket of eolian sand. Within the immediate area, several arroyos and exposures beneath the eolian sand show a well-developed soil that is offset 4-6 $\mathrm{m}$ by the La Jencia fault. The trench was excavated on a ramp of eolian sand that partly buries the fault scarp.

The piedmont surface near trench-site 4 is overlain by a blanket of eolian sand, which is commonly 1-2 m thick east of the fault (the leeward side of the fault) and less than $1 / 2 \mathrm{~m}$ thick west of the fault. The sand is part of a broad north-northeast-trending plume both north and 
south of La Jencia Creek (pl. 2). Deposition of the sand probably began during the latest part of the Pleistocene, after 12-13 ka ago (Weber and Sterns, 1965), when the northern arm of San Agustin lake (White Lake of Markgraf and others, 1984) became desiccated. Clovisage artifacts (mainly 11-12 ka old) were along both the high shoreline of the lake and the margins of the modern playa (R. H. Weber, oral commun., 1980). Weber believes that the northernmost of the lakes had become desiccated and that wind was actively eroding the basin by $11.5 \mathrm{ka}$ ago.

The presence of Folsom sites (mainly 10-11 ka old) primarily on the desiccated floor of White Lake (R. H. Weber, oral commun., 1980) suggests a later (that is, earliest Holocene or latest Pleistocene) slight moistening of climate that resulted in revegetation and restabilization of much of the landscape in the basin. Thus, on the basis of sparse archeologic and stratigraphic evidence, I believe that the sand plume at trench-site 4 probably was emplaced during the latest Pleistocene and earliest Holocene but that most of the sand movement, in the regional sense, probably had ceased by $10 \mathrm{ka}$ ago.

Trench-site 4 is the driest of the four sites. The meanannual precipitation is estimated to be about $25 \mathrm{~cm}$, most of which falls between June to September as thunderstorms traverse the Bear Mountains and the La Jencia basin. Mean-annual temperature is estimated to be about $12^{\circ} \mathrm{C}$, the same as at trench-site 3 , which is 5 $\mathrm{km}$ to the south and $45 \mathrm{~m}$ higher. Pre-Holocene soils in this area have $\mathrm{B}$ horizons that are markedly calcareous, indicating a long history of arid to semiarid climate.

Vegetation at the site is a sparse assemblage of shortgrass, yuccas, and chollas. Pinon pine and juniper trees are absent; the nearest stable communities of trees are $1-2 \mathrm{~km}$ to the west on higher north-facing (moist) slopes of the Bear Mountains. The ground surface at trenchsite 4 is characterized by small patches of unstabilized eolian sand and many small coppice dunes anchored by clumps of vegetation.

The La Jencia fault forms a scarp that is indistinct near trench-site 4 because it is partly buried by eolian sand. The scarp trends generally north from La Jencia Creek, but short sections trend north-northwest. The unnamed but small prominent peak in sec. 31, T. $1 \mathrm{~S}$., R. $3 \mathrm{~W}$. (pl. 2), forms an effective barrier to sand that is transported from the west. As a result, the fault cuts uncovered piedmont-slope deposits directly east of the .small peak. Drainage in this area is aligned along the base of the scarps, and along the toe of the scarp are several closed depressions that probably are grabens.

Within the northern half of sec. 31 and all of sec. 30 (adjacent to the site), studies of the scarp's morphology could not be made because it is largely buried by eolian sand, whereas at the three other trench sites the scarps were subject to normal processes of degradation. Thus, the later discussion of scarp morphology (see the section on "Scarp-Profile Data" for the La Jencia fault) does not include the scarps near trench-site 4.

\section{GEOLOGIC INVESTIGATIONS}

Excavation of trench 4 was made difficult by a thick section of loose eolian sand along the base of the fault scarp. The initial excavation penetrated old soils and alluvium in the downdropped block, but these were soon covered by sand that slumped into the trench. Trench walls more than $2 \mathrm{~m}$ high were not stable even when shored, so a wide cut was made about $1 \mathrm{~m}$ deep, and within it a narrower and deeper trench was dug in sand that was slightly more cohesive. Although deposits from the upper $1 \mathrm{~m}$ of the trench wall on the downdropped side of the fault could not be mapped, data for these deposits were obtained by augering adjacent to the trench (pl. 1D).

The upthrown fault block at trench 4 (fig. 9) is characterized by thin layers of coarse-grained alluvium that are overlain by a thin blanket of eolian sand. A weakly developed surface soil (W) and an underlying well-developed soil (Y) were exposed in the upper $2 \mathrm{~m}$ of the western half of trench 4. These soils were sampled in the northeastern end of trench 4 where they were least disturbed by rodent burrows and collapse pipes that intrude the calcareous horizons of soil $\mathrm{Y}$ (units bo and 10, pl. 1D).

Profile T4-1 is a composite of two soils of distinctly different age. The upper soil (unit 5 , soil $W$, table 13 ) is about $3 / 4 \mathrm{~m}$ thick on fine-grained eolian sand of latest Pleistocene and earliest Holocene age; the sand has a loamy sand texture (table 13). The lower soil (soil Y, table 14) is about $1 \frac{1 / 2}{\mathrm{~m}}$ thick on admixed eolian sand and coarse-grained alluvium (units 9-11) that are several hundred thousand years old (late? middle Pleistocene).

Soil $\mathrm{W}$ is characterized by the $5 \mathrm{Bt}$ horizon, which, although poorly developed, has a weak, fine subangular blocky structure and a few thin clay films on sand grains (table 13); these two features indicate at least a weak accumulation of pedogenic clay. The clay content of the less than 2-mm-size fraction of soil $\mathrm{W}$ (table 13) ranges from 8 to 9 percent in the basal $24 \mathrm{~cm}$ to a maximum of 12 to 13 percent in the upper 5B21t and 5B22t horizons. The net increase of 4 percent clay in the $\mathrm{Bt}$ horizon is somewhat impressive, considering that the eolian sand is quite young.

The total clay content for soil W (samples T4-1a through T4-1g, table 13) was calculated as in previous examples and based on an initial bulk density of $1.65 \mathrm{~g} / \mathrm{cm}^{2}$ and a primary clay content of $8-9$ percent. A total of $12.6 \mathrm{~g} / \mathrm{cm}^{2}$ of clay is now present; of this, 9.1-10.2 $\mathrm{g}$ is primary, and the remaining $2.4-3.5 \mathrm{~g}$ is 


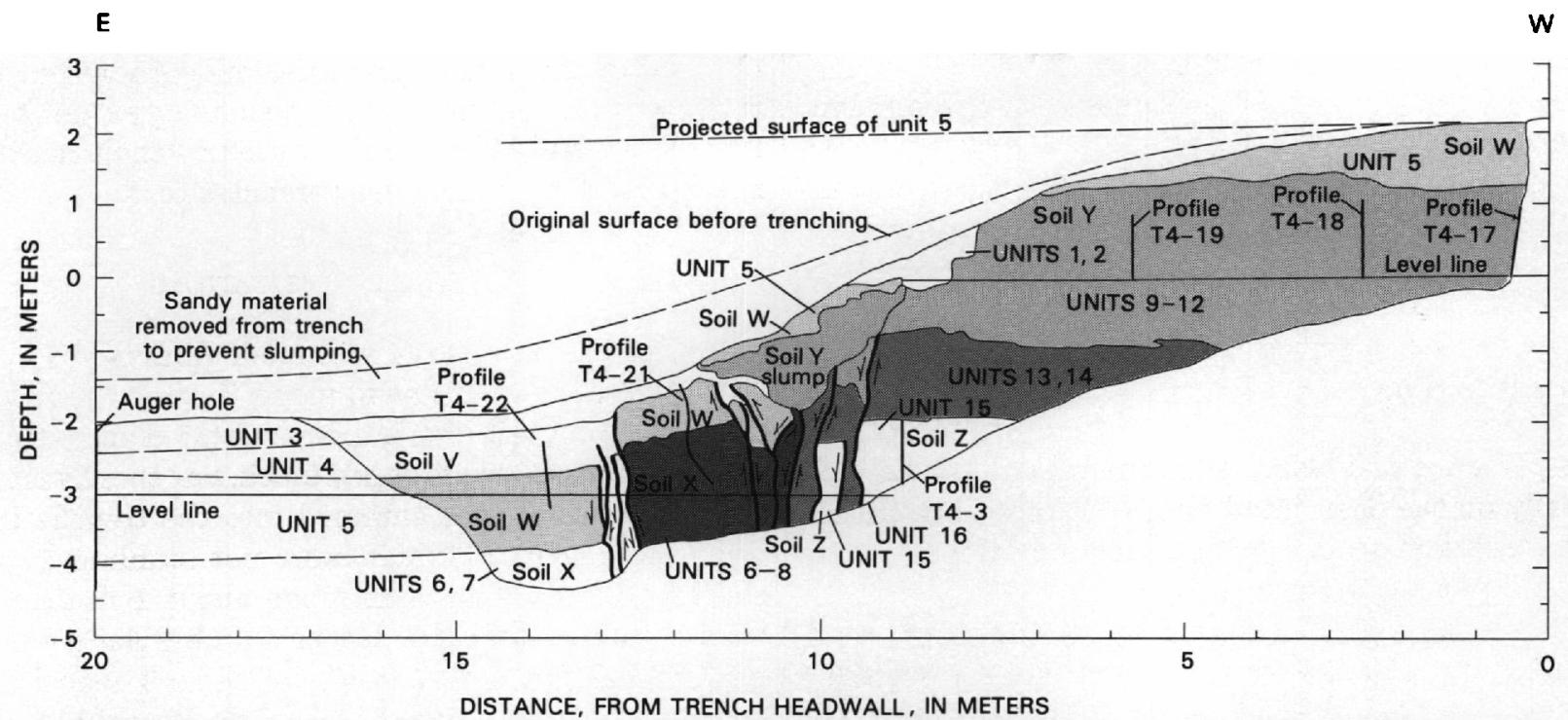

Figure 9.-Simplified sketch map of major geologic and soil units in trench 4. See plate 1D for detailed section; south wall of trench mapped. Horizontal and vertical distances measured from upper end of trench and highest level line, respectively. Direction of movement along faults (heavy lines) shown by arrows. Units 1-16 are described in the section on "Description of Soil Parent Materials" on plate 1. Soils V, W, X, Y, and Z are described in the section on "Description of Soil Horizons in Trench 4."

secondary. The age of unit 5 (eolian sand) is considered to be 9-11 ka based on the late Pleistocene history of the San Agustin lake system. For the purpose of further discussion, I consider that the eolian sand (unit 5) became stable about $10 \mathrm{ka}$ ago; thus, the corresponding average rate of clay accumulation for soil $\mathrm{W}$ is $0.24-0.35$ $\mathrm{g} / \mathrm{cm}^{2} / \mathrm{ka}$. Soil W has a net increase in clay content of $2.4-3.5 \mathrm{~g} / \mathrm{cm}^{2}$, which is about the same or slightly less than that of mid-Holocene soils having argillic B horizons in southern New Mexico (table 2); however, soil $\mathrm{W}$ is probably 3,000 to 4,000 years older. The $\mathrm{B}$ horizon of soil $\mathrm{W}$ has about three times as much clay and is nearly twice as old as the Holocene surface soil (E). Therefore, the effective rate of clay accumulation in soil $\mathrm{W}$ is about $1 \frac{1 / 3}{3}$ to 2 times faster than in soil $\mathrm{E}$ $\left(0.18 \mathrm{~g} / \mathrm{cm}^{2}\right)$.

The 5Bt horizon of soil $\mathrm{W}$ rests unconformably on a slightly truncated Bt horizon of a much older, strongly developed soil (soil Y on units 9-12, fig. 9). Unit 9 probably was a fine-grained eolian sand, but evidence of its initial texture and origin are now largely obliterated by the formation of soil Y. Unit 9 has a low content of gravel and a high degree of sorting; both suggest an eolian origin. The underlying deposits (units 10-12) are also much modified by soil formation, but the grain-size data (table 14) and preservation of sparse bedding suggest that they are largely of alluvial origin. The abundance of animal burrows (crotovinas) and collapse pipes in units 9-11 indicates substantial prehistoric bioturbation and dissolution(?) within the soil.
The buried soil Y (fig. 9; units 9-12, pl. 1D) has a strongly developed $\mathrm{Bt}$ horizon that is calcareous (9B22tcab and 9B23tcab subhorizons). The Bt horizon has $5 Y R$ hues, the chroma and value being dependent upon carbonate content (table 14). Peds have moderate to strong, coarse and medium subangular blocky structure. Clay films on ped faces are common and thick, particularly in the 9B23tcab horizon. The well-developed nature of the $9 \mathrm{Bt}$ horizon is illustrated by a maximum of 27.3 percent clay in the less-than-2-mm fraction (table 14, 9B22tca subhorizon); this content represents a substantial increase over an original clay content that is estimated to have been about 5-10 percent (lessthan-2-mm fraction). Unit 10, the next lower unit in soil $Y$, fills old crotovinas and dissolution pipes and consists of Bt and Bca horizons, which are laterally discontinuous. These horizons are nearly as well developed as adjacent subhorizons of the $9 \mathrm{Bt}$, indicating that the burrows and pipes were infilled early in the history of soil Y.

Several moderately well developed calcic horizons are present below the 9Bt horizon. The soils on the upthrown fault block are disturbed by burrows and pipes, so four different vertical channels were sampled (profiles T4-16, T4-17, T4-18, T4-19, pl. 1D) and analyzed for calcium carbonate content and bulk density to better characterize these calcic horizons. The maximum accumulation of carbonate is between 28 and 39 percent in the upper 10-25 cm of the channel (11K2 horizon). Below the $11 \mathrm{~K} 2$ horizon, carbonate content declines with depth, to a minimum of about 5 percent in the $12 \mathrm{Cca}$ horizon. 
TABLE 13.-Laboratory data and field description for soil W, profile T4-1 (upper part), trench 4, La Jencia fault LABORATORY DATA

[Grain-size analyses of noncalcareous soil fraction in percent; vc, very coarse; c, coarse; m, medium; f, fine; vf, very fine; $\mu \mathrm{m}$, micrometers; <, less than; $>$ greater than. Laboratory analyses by Donald Cheney, U.S. Goological Survey]

\begin{tabular}{|c|c|c|c|c|c|c|c|c|c|c|c|c|c|c|c|c|}
\hline \multirow{2}{*}{$\begin{array}{l}\text { Grain-size } \\
\text { Grain-size }\end{array}$} & \multirow{2}{*}{\multicolumn{2}{|c|}{$\begin{array}{l}\text { classes-os } \\
\text { categories- }\end{array}$}} & \multicolumn{3}{|c|}{$<2-m m$ fraction } & \multicolumn{5}{|c|}{ Sand (mm) } & \multicolumn{2}{|c|}{ Silt $(\mu \mathrm{m})$} & \multicolumn{2}{|c|}{$\mathrm{Clay}(\mu \mathrm{m})$} & \multirow[t]{2}{*}{ Whole } & \multirow[t]{2}{*}{ sample } \\
\hline & & & Sand & Silt & Clay & ve & $\mathrm{c}$ & $m$ & $\mathrm{f}$ & vf & $\mathrm{c}$ & $\mathrm{f}$ & c & $\mathrm{f}$ & & \\
\hline $\begin{array}{l}\text { Grain sizes } \\
\text { Sample } \\
\text { No. }\end{array}$ & $\begin{array}{l}\text { S (mm)-- } \\
\text { Depth } \\
(\mathrm{cm})\end{array}$ & $\begin{array}{l}\text { Horizon or } \\
\text { subhorizon }\end{array}$ & $\begin{array}{l}(2.0- \\
0.05)\end{array}$ & $\begin{array}{c}(0.05- \\
0.002)\end{array}$ & $(<0.002)$ & $(2-1)$ & $(1-0.5)$ & $\begin{array}{c}(0.5- \\
0.25)\end{array}$ & $\begin{array}{c}(0.25- \\
0.1)\end{array}$ & $\begin{array}{c}(0.1- \\
0.05)\end{array}$ & $(50-20)$ & $(20-2)$ & $(2-0.5)$ & $(<0.5)$ & $(<2 \mathrm{~mm})$ & $(>2 \mathrm{~mm}$ \\
\hline T4-1a---- & $0-9--$ & $5 A-\cdots-\cdots$ & 90.8 & 4.0 & 5.2 & 0.4 & 2.3 & 16.1 & 50.2 & 21.5 & 2.1 & 1.9 & 1.6 & 3.6 & 95.4 & 4.6 \\
\hline$T 4-1 b----$ & $9-20-$ & $5 B 1 t-\ldots$ & 83.0 & 6.2 & 10.8 & .5 & 2.8 & 19.8 & 49.9 & 10.0 & 3.6 & 2.6 & 2.2 & 8.6 & 98.1 & 1.9 \\
\hline T4-1c---- & $20-30$ & $5 B 21 t----$ & 81.7 & 8.5 & 12.8 & .1 & 2.1 & 15.2 & 48.8 & 15.5 & 2.3 & 3.2 & 2.5 & 10.3 & 100.0 & .0 \\
\hline T4-1d---- & $30-40$ & $5 B 22 t-\cdots$ & 78.8 & 8.7 & 12.5 & .1 & 1.7 & 15.0 & 47.7 & 14.3 & 5.1 & 3.6 & 2.2 & 10.3 & 100.0 & .0 \\
\hline T4-1e--- & $40-52$ & $5 B 23 t-\cdots$ & 78.1 & 11.2 & 11.7 & .3 & 2.0 & 13.9 & 46.8 & 16.9 & 6.2 & 4.0 & 3.2 & 8.5 & 99.0 & 1.0 \\
\hline T4-1f --- & $52-69$ & $5 \operatorname{Cox}-\cdots$ & 79.4 & 11.8 & 8.8 & .3 & 2.3 & 16.4 & 47.2 & 13.2 & 6.9 & 4.9 & 2.0 & 6.8 & 100.0 & .0 \\
\hline T $4-1 \mathrm{~g}=-$ & $69-76$ & $5 \mathrm{C}$ and $9 \mathrm{Bb}$ & 88.0 & 4.3 & 7.7 & 1.0 & 3.7 & 21.5 & 52.3 & 9.5 & 2.5 & 1.8 & 1.2 & 6.5 & 96.7 & 3.3 \\
\hline
\end{tabular}

[Grain-size analyses of gravel fraction, organic-matter content, and calcium carbonate content in percent; bulk density in g/cm ${ }^{9} ;$ f, fine; m, medium; c, coarse; <, less than; >, greater than; n.d., not determined; Do., ditto. Laboratory analyses by Donald Cheney, U.S. Geological Survey]

\begin{tabular}{|c|c|c|c|c|c|c|c|c|c|c|}
\hline \multirow[b]{2}{*}{$\begin{array}{l}\text { Grain-size categories } \\
\text { Grain sizes (mm)--.- } \\
\text { Sample } \\
\quad \text { No. }\end{array}$} & \multicolumn{3}{|c|}{ Gravel $(>2 \mathrm{~mm})$} & \multirow[b]{2}{*}{$\begin{array}{l}\text { Organic } \\
\text { matter }\end{array}$} & \multirow[b]{2}{*}{$\mathrm{pH}$} & \multicolumn{2}{|c|}{ Bulk density } & \multicolumn{2}{|c|}{$\mathrm{CaCO}_{3}$} & \multirow[b]{2}{*}{ Texture } \\
\hline & $(2-19)$ & $(19-76)$ & $\frac{c}{(>76)}$ & & & $<2 \mathrm{~mm}$ & $\begin{array}{l}\text { Whole } \\
\text { sample }\end{array}$ & $<2 \mathrm{~mm}$ & $\begin{array}{l}\text { Whole } \\
\text { sample }\end{array}$ & \\
\hline $\begin{array}{l}\text { T } 4-1 \mathrm{a} \\
\text { T } 4-1 \mathrm{~b} \\
\text { T } 4-1 \mathrm{c} \\
\text { T } 4-1 \mathrm{~d} \\
\text { T } 4-1 \mathrm{e} \\
\text { T } 4-1 \mathrm{f} \\
\text { T } 4-1 \mathrm{~g}\end{array}$ & $\begin{array}{l}100.0 \\
100.0 \\
100.0 \\
100.0 \\
100.0 \\
100.0 \\
100.0\end{array}$ & $\begin{array}{r}0.0 \\
.0 \\
.0 \\
.0 \\
.0 \\
.0 \\
.0\end{array}$ & $\begin{array}{l}0.0 \\
.0 \\
.0 \\
.0 \\
.0 \\
.0 \\
.0\end{array}$ & $\begin{array}{l}\text { n.d. } \\
\text { n.d. } \\
\text { n.d. } \\
\text { n.d. } \\
\text { n.d. } \\
\text { n.d. } \\
\text { n.d. }\end{array}$ & $\begin{array}{l}\text { n.d. } \\
\text { n.d. } \\
\text { n.d. } \\
\text { n.d. } \\
\text { n.d. } \\
\text { n.d. } \\
\text { n.d. }\end{array}$ & $\begin{array}{l}\text { n.d. } \\
\text { n.d. } \\
\text { n.d. } \\
\text { n.d. } \\
\text { n.d. } \\
\text { n.d. } \\
\text { n.d. }\end{array}$ & $\begin{array}{l}{ }^{*} 1.6 \\
{ }^{*} 1.65 \\
* 1.65 \\
*_{1} .65 \\
*_{1} .65 \\
1.65 \\
\text { n.d. } \\
\text { n.d. }\end{array}$ & $\begin{array}{l}0.4 \\
.4 \\
.4 \\
.4 \\
.4 \\
.4 \\
.4\end{array}$ & $\begin{array}{l}0.4 \\
.4 \\
.4 \\
.4 \\
.4 \\
.4 \\
.4\end{array}$ & $\begin{array}{l}\text { Sand plus. } \\
\text { Loamy sand. } \\
\text { Sandy loam. } \\
\text { Do. } \\
\text { Sandy loam minus. } \\
\text { Loamy sand. } \\
\text { Loamy sand minus. }\end{array}$ \\
\hline
\end{tabular}

${ }^{*}$ Estimated value. 
FIELD DESCRIPTION

[See table 1 for abbreviations; do., ditto. Lower part of profile T4-1, starting at 76-cm depth, shown in table 14]

SOIL PROFILE: T4-1, soil $W$, trench 4.

DESCRIBED BY: M. N. Machette.

DATE: November $15,1978$.

PARENT MATERIAL: Eolian sand (unit 5).

AGE: Latest Pleistocene and earliest Holocene (9-13 ka).

LOCATION: North wall of trench $4,1.8 \mathrm{~m}$ east of headwall, NW/4 SW1/4SE $1 / 4 \mathrm{sec} .30, \mathrm{~T} .1 \mathrm{~S} ., \mathrm{R} .3 \mathrm{~W}$. , Magdalena 15 -minute quadrangle.

GEOGRAPHICAL LANDSCAPE: Piedmont slope above fault scarp.

SOIL DEVELOPMENT: Soil $\mathrm{W}$, weak.

ELEVATION: $1,841 \mathrm{~m}$ SLOPE: $1 \mathrm{H}_{2}^{\circ} \quad$ ASPECT: East. EROSION: None.

CLIMATE: Semiarid: estimated mean-annual temperature, $12{ }^{\circ} \mathrm{C}$; mean-annual precipitation, $25 \mathrm{~cm}$.

VEGETATION: Scattered shortgrass, yucca, and cholla.

\begin{tabular}{|c|c|c|c|c|c|c|c|c|c|}
\hline $\begin{array}{l}\text { Sample } \\
\text { No. }\end{array}$ & $\begin{array}{l}\text { Depth } \\
(\mathrm{cm})\end{array}$ & Hor i zon & Color & Texture & Structure & $\begin{array}{l}\text { Consist- } \\
\text { ence }\end{array}$ & $\begin{array}{l}\text { Clay } \\
\text { films }\end{array}$ & $\mathrm{CaCO}_{3}$ & Comments \\
\hline T4-1a-- & $0-9--$ & $5 \mathrm{~A}^{-\cdots}-\cdots$ & $8 \underline{Y K 5} 5.5 / 4 d-\cdots$ & $\mathrm{Sa}(+)-$ & sg--.-.- & so, & None---.-- & None--- & $\begin{array}{l}\text { Loose when dry; abrupt, smoooth } \\
\text { boundary. }\end{array}$ \\
\hline $\mathrm{T} 4-1 \mathrm{~b}--$ & $9-20-$ & $5 B 1 t-\cdots$ & $7 \underline{Y R} 4.5 / 4 d-\cdots$ & LSa--- & vwf sab-- & $\begin{array}{l}\text { vss, } \\
\text { po. }\end{array}$ & $\begin{array}{l}\text { Very few, } \\
\text { very thin. }\end{array}$ & None--- & Friable when dry. \\
\hline T4-1c-- & $20-30$ & $5 B 21 t-\cdots$ & $7 \underline{\underline{Y R}} 4.5 / 5 \mathrm{~d}---$ & SaL--- & wfsab--- & $\begin{array}{l}\text { ss, } \\
\text { vsp. }\end{array}$ & --- do. $-\cdots$ & None--- & $\begin{array}{l}\text { Slightly firm when dry; clear, smooth } \\
\text { lower boundary. }\end{array}$ \\
\hline $\mathrm{T} 4-1 \mathrm{~d}--$ & $30-40$ & $5 B 22 t----$ & $7.5 \underline{Y R} 5 / 5 \mathrm{~d}-\cdots$ & SaL--- & wfab---- & ss, & ----do.---- & None--- & Firm when dry. \\
\hline T4-1e-- & $40-50$ & $5 B 23 t-\cdots$ & 7.5 YR $5.5 / 5 \mathrm{~d}-$ & $\operatorname{SaL}(-)$ & wf sab--- & $\begin{array}{l}\text { ss, } \\
\text { vsp. }\end{array}$ & ---- do..--- & None--- & $\begin{array}{l}\text { Firm when dry; clear, smooth lower } \\
\text { boundary. }\end{array}$ \\
\hline T4-1f-- & $50-69$ & $5 \operatorname{Cox}-\cdots-$ & $7.5 \mathrm{YR} 5.5 / 4 d-$ & LSa--- & $\begin{array}{l}\text { vwfsab } \\
\text { to sg. }\end{array}$ & $\begin{array}{l}\text { vss, } \\
\text { po. }\end{array}$ & None---.--- & None--- & $\begin{array}{l}\text { Friable to loose when dry; cementation } \\
\text { is irregular. }\end{array}$ \\
\hline $\mathrm{T} 4-1 \mathrm{~g}--$ & $69-76$ & $\begin{array}{l}5 \operatorname{Cox} \\
\quad \text { and } 9 B .\end{array}$ & $7.5 \underline{Y Y R}$ to & $\mathrm{LSa}(-)$ & $\begin{array}{l}\text { wmsab } \\
\text { and } \mathrm{sg} \text {. }\end{array}$ & $\begin{array}{l}\text { vss, } \\
\text { po. }\end{array}$ & None--..--- & None--- & $\begin{array}{l}\text { Mixed horizon: consists of subhorizons } \\
5 \operatorname{Cox} \text { and } 9 B \text { of soil } Y \text {. }\end{array}$ \\
\hline
\end{tabular}


TABLE 14.-Laboratory data and field description for soil Y, profile T4-1 (hower part), trench 4, La Jencia fault LABORATORY DATA

[Grain-size analyses of noncalcareous soil fraction in percent; vc, very coarse; c, coarse; m, medium; f, fine; vf, very fine; $\mu m$, micrometers; <, lese than; >, greater than. Laboratory analyses by Donald Cheney, U.S. Geological Survey]

\begin{tabular}{|c|c|c|c|c|c|c|c|c|c|c|c|c|c|c|c|c|}
\hline \multirow{3}{*}{\multicolumn{3}{|c|}{$\begin{array}{l}\text { Grain-size classes } \\
\text { Grain-size categories } \\
\text { Grain sizes (mm) }\end{array}$}} & \multicolumn{3}{|c|}{ <2-mm fraction } & \multicolumn{5}{|c|}{ Sand $(\mathrm{mm})$} & \multicolumn{2}{|c|}{ Silt $(\mu \mathrm{m})$} & \multicolumn{2}{|c|}{ Clay $(\mu \mathrm{m})$} & \multicolumn{2}{|c|}{ Whole sample } \\
\hline & & & Sand & Silt & Clay & ve & c & $\mathrm{m}$ & $f$ & $\mathrm{vf}$ & c & $\mathrm{f}$ & $\mathrm{c}$ & $\mathrm{f}$ & & \\
\hline & & & $(2.0-$ & $\left(0.05^{-}\right.$ & $(<0.002)$ & $(2-1)$ & $(1-0.5)$ & $10.5^{-}$ & $10.25-$ & $10.1-$ & $(50-20)$ & $(20-2)$ & $(2-0.5)$ & $(<0.5)$ & $(<2 \mathrm{~mm})$ & $(>2 \mathrm{~mm})$ \\
\hline $\begin{array}{c}\text { Sample } \\
\text { No. }\end{array}$ & $\begin{array}{l}\text { Depth } \\
(\mathrm{cm})\end{array}$ & $\begin{array}{l}\text { Horizon or } \\
\text { subhorizon }\end{array}$ & $0.05)$ & $0.002)$ & & & & $0.25)$ & $0.1)$ & $0.05)$ & & & & & & \\
\hline$T 4-1 \mathrm{~h} \cdots$ & $76-85--$ & 9B1tb- - - & 77.9 & 5.0 & 17.1 & 2.0 & 3.4 & 17.0 & 36.1 & 8.8 & 3.1 & 1.9 & 1.8 & 15.3 & 89.1 & 10.9 \\
\hline T4-11-... & $85-97--$ & $9 B 21 \mathrm{tb}-\cdots$ & 72.1 & 6.5 & 21.4 & 1.1 & 3.4 & 15.2 & 44.7 & 8.4 & 3.4 & 2.4 & 1.8 & 19.6 & 98.4 & 1.6 \\
\hline T4-1j--- & $97-109-$ & 9822tcab-- & 66.6 & 6.1 & 27.3 & 1.3 & 3.0 & 15.2 & 39.5 & 7.6 & 3.6 & 1.5 & 4.1 & 23.2 & 98.1 & 1.9 \\
\hline T4-1k---- & $109-120$ & 9B23tcab-- & 69.4 & 9.4 & 21.2 & 1.0 & 2.3 & 14.1 & 41.6 & 10.4 & 5.4 & 5.4 & 6.0 & 15.2 & 98.0 & 2.0 \\
\hline T4-11-..- & $120-133$ & $11 \mathrm{~K} 22 \mathrm{~b} \cdots$ & 70.9 & 8.7 & 20.4 & 1.6 & 3.4 & 13.9 & 42.6 & 9.4 & 3.4 & 5.3 & 7.5 & 12.9 & 99.1 & .9 \\
\hline T4-1m-- - & $133-145$ & $11 \mathrm{~K} 23 \mathrm{~b}-\cdots$ & 76.1 & 7.0 & 16.9 & 2.8 & 3.8 & 14.8 & 45.9 & 8.8 & 2.7 & 4.3 & 5.6 & 11.3 & 91.4 & 8.6 \\
\hline T4-1n---- & $145-162$ & $11 \mathrm{~K} 31 \mathrm{~b} \cdots$ & 78.8 & 6.9 & 14.3 & 2.2 & 3.6 & 15.3 & 47.1 & 10.6 & 4.2 & 2.7 & 3.8 & 10.5 & 96.9 & 3.1 \\
\hline T4-10---. & $162-180$ & $11 \mathrm{~K} 32 \mathrm{~b}---$ & 82.0 & 7.8 & 10.2 & 2.4 & 3.1 & 16.0 & 47.2 & 12.3 & 4.2 & 3.6 & 4.0 & 6.2 & 93.6 & 6.4 \\
\hline T4-1p- & $180-205$ & 11 C1cab--- & 81.0 & 5.4 & 13.6 & 3.6 & 4.9 & 16.6 & 46.2 & 9.7 & 2.4 & 3.0 & 2.4 & 11.2 & 94.5 & 5.5 \\
\hline T4-1 q---- & $205-220$ & $11 \mathrm{c} 2 \mathrm{cab}---$ & 80.5 & 6.4 & 13.1 & 2.7 & 4.3 & 17.1 & 47.9 & 8.5 & 3.8 & 2.6 & 3.9 & 9.2 & 96.0 & 4.0 \\
\hline
\end{tabular}

[Grain-size analysees of gravel fraction, organic-matter content, and calcium carbonate content in percent; bulk density in $\mathrm{g}^{\mathrm{c}} \mathrm{cm}^{3}$; f, fine; m, medium; c, coarse; <, less than; >, greater than; n.d., not determined; Do., ditto. Laboratory analyses by Donald Cheney, U.S. Geological Surveyl

\begin{tabular}{|c|c|c|c|c|c|c|c|c|c|c|}
\hline \multirow[b]{2}{*}{$\begin{array}{l}\text { Grain-size categories } \\
\text { Grain sizes (mm)-..- } \\
\text { Sample } \\
\quad \text { No. }\end{array}$} & \multicolumn{3}{|c|}{ Gravel $(>2 \mathrm{~mm})$} & \multirow[b]{2}{*}{$\begin{array}{l}\text { Organic } \\
\text { matter }\end{array}$} & \multirow[b]{2}{*}{$\mathrm{pH}$} & \multicolumn{2}{|c|}{ Bulk density } & \multicolumn{2}{|c|}{$\mathrm{CaCO}_{3}$} & \multirow[b]{2}{*}{ Texture } \\
\hline & $\frac{f}{(2-19)}$ & $\frac{m}{(19-76)}$ & $\frac{c}{(>76)}$ & & & $<2 \mathrm{~mm}$ & $\begin{array}{l}\text { Whole } \\
\text { sample }\end{array}$ & $<2 \mathrm{~mm}$ & $\begin{array}{l}\text { Whole } \\
\text { sample }\end{array}$ & \\
\hline 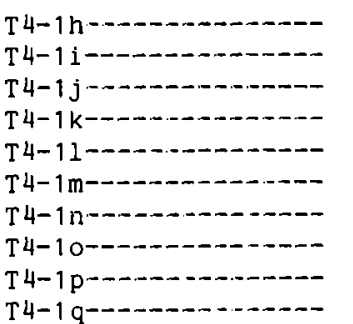 & $\begin{array}{l}100.0 \\
100.0 \\
100.0 \\
100.0 \\
100.0 \\
100.0 \\
100.0 \\
100.0 \\
100.0 \\
100.0\end{array}$ & $\begin{array}{l}0.0 \\
.0 \\
.0 \\
.0 \\
.0 \\
.0 \\
.0 \\
.0 \\
.0 \\
.0\end{array}$ & $\begin{array}{l}0.0 \\
.0 \\
.0 \\
.0 \\
.0 \\
.0 \\
.0 \\
.0 \\
.0 \\
.0\end{array}$ & $\begin{array}{l}\text { n.d. } \\
\text { n.d } \\
\text { n.d. } \\
\text { n.d. } \\
\text { n.d. } \\
\text { n.d. } \\
\text { n.d. } \\
\text { n.d. } \\
\text { n.d. } \\
\text { n.d. }\end{array}$ & $\begin{array}{l}\text { n.d. } \\
\text { n.d. } \\
\text { n.d. } \\
\text { n.d. } \\
\text { n.d. } \\
\text { n.d. } \\
\text { n.d. } \\
\text { n.d. } \\
\text { n.d. } \\
\text { n.d. }\end{array}$ & $\begin{aligned} 1.65 \\
1.75 \\
1.73 \\
1.75 \\
1.51 \\
1.63 \\
1.53 \\
\neq_{1.6} \\
1.58 \\
\neq 1.6\end{aligned}$ & $\begin{array}{l}1.76 \\
1.76 \\
1.75 \\
1.77 \\
1.52 \\
1.72 \\
1.57 \\
* 1.89 \\
* 1.73 \\
1.88\end{array}$ & $\begin{array}{r}0.8 \\
.6 \\
.8 \\
1.8 \\
34.8 \\
27.2 \\
23.7 \\
7.1 \\
6.9 \\
1.3\end{array}$ & $\begin{array}{r}0.7 \\
.6 \\
.8 \\
1.8 \\
34.5 \\
24.9 \\
23.0 \\
6.6 \\
6.5 \\
1.2\end{array}$ & $\begin{array}{l}\text { Sandy loam. } \\
\text { Sandy clay loam minus. } \\
\text { Sandy clay loam. } \\
\text { Sandy clay loam minus. } \\
\text { Do. } \\
\text { Sandy loam. } \\
\text { Sandy loam minus. } \\
\text { Loamy sand. } \\
\text { Loamy sand plus. } \\
\text { Do. }\end{array}$ \\
\hline
\end{tabular}

\footnotetext{
FEstimated value.
} 
FIELD DESCRIPTION

[Soe table 1 for abbreviations; do., ditto. Upper part of profile T4-1 shown in table 13]

SOIL PROFILE: T4-1 (lower part), soil $Y$, trench 4. DESCRIBED BY: M. N. Machette.

DATE: November $15,1978$.

PARENT MATERIAL: Admixed eolian sand (mostly units 9 and 10) and fine-grained alluvium (unit 11 ).

AGE: Late(?) middle Pleistocene (several hundred thousand years).

LOCATION: North wall of trench $4,1.8 \mathrm{~m}$ east of headwall, NW/4WW/4EE/4 sec. $30, \mathrm{~T}, 1 \mathrm{~s} ., \mathrm{R} .3 \mathrm{~W} .$,

Magdalena 15-minute quadrangle.

GEOGRAPHICAL LANDSCAPE: Piedmont slope above fault scarp. SOIL DEVELOPMENT: Soil $Y$, moderately strong.
ELEVATION: $1,841 \mathrm{~m}$
SLOPE: $1 \frac{1}{2}$
ASPECT: East.
EROSION: None.

CLIMATE: Semiarid: estimated mean-annual temperature, $12{ }^{\circ} \mathrm{C}$; mean-annual precipitation, $25 \mathrm{~cm}$.

VEGETATION: Scattered short grasses, yucca, and cholla.

REMARKS: 9Bltb subhorizon overlain by basal subhorizon (mixed $5 \mathrm{Cox}$ and $9 \mathrm{~B}$ ) of soil $\mathrm{W}$ (table 13 ).

\begin{tabular}{|c|c|c|c|c|c|c|c|c|c|}
\hline $\begin{array}{l}\text { Sample } \\
\text { No. }\end{array}$ & $\begin{array}{l}\text { Depth } \\
(\mathrm{cm})\end{array}$ & Horizon & Color & Texture & Structure & $\begin{array}{l}\text { Consist- } \\
\text { ence }\end{array}$ & $\begin{array}{c}\mathrm{Clay} \\
\text { films }\end{array}$ & $\mathrm{CaCO}_{3}$ & Comments \\
\hline T4-1h--- & $76-85--$ & $981 t b-\cdots--$ & 5YR5/6d----- & SaL---- & mmsab--- & ss, & $\begin{array}{l}\text { Few, thin } \\
\text { on peds. }\end{array}$ & None------ & $\begin{array}{l}\text { Common pebbles as large as } 5-10 \mathrm{~cm} \text {; } \\
\text { gradual, smooth boundary. }\end{array}$ \\
\hline T4-1i--- & $85-97--$ & $9 \mathrm{~B} 21 \mathrm{tb}---$ & $5 \underline{Y R} 5 / 6 d \cdots-$ & $\operatorname{SaCL}(-)$ & $\begin{array}{l}\text { scsab to } \\
\text { smsab. }\end{array}$ & s, sp. & $\begin{array}{l}\text { Common, } \\
\text { thin on } \\
\text { peds. }\end{array}$ & None--...- & $\begin{array}{l}\text { Pebbles sparse, } 3-4 \mathrm{~cm} \text { diameter; } \\
\text { abrupt, wavy boundary. }\end{array}$ \\
\hline$T 4-1 j---$ & $97-109-$ & 9B22tcab- & $\begin{array}{l}5 \mathrm{YR} 5 / 6 \mathrm{~d} \text { to } \\
5 \mathrm{YR} 4.5 / 6 \mathrm{~d}\end{array}$ & SaCL--- & $\begin{array}{l}\text { sesab to } \\
\text { smsab. }\end{array}$ & $\mathrm{s}, \mathrm{p}$ & ---do.--- & m stg I--- & Clear, wavy boundary. \\
\hline $\mathrm{T} 4-1 \mathrm{k}---$ & $109-120-$ & 9B23tcab- & $5 \underline{Y R} 4.5 / 6 \mathrm{~d}-\cdots$ & $\operatorname{SaCL}(-)$ & smsab--- & s.p. & $\begin{array}{l}\text { Common, } \\
\text { thick } \\
\text { on peds. }\end{array}$ & $\begin{array}{l}m \text { stg } I \\
\text { and } I I\end{array}$ & $\begin{array}{l}\text { Carbonate coats on some ped faces; } \\
\text { clear, wavy boundary. }\end{array}$ \\
\hline T4-11--- & $120-133-$ & $11 \mathrm{~K} 22 \mathrm{~b}---$ & $\frac{5 Y R 8 / 1 d}{t_{0}}$ white. & $\operatorname{SaCL}(-)$ & $\begin{array}{l}\text { mmsab to } \\
\text { mcpl.1 }\end{array}$ & ss, & Obscured- & m stg III- & $\begin{array}{l}\text { Hard when dry; gradual, smooth } \\
\text { boundary. }\end{array}$ \\
\hline $\mathrm{T} 4-1 \mathrm{~m}---$ & $133-145-$ & $11 \mathrm{~K} 23 \mathrm{~b}---$ & $5 \underline{Y R} 8 / 1 d$ & $\begin{array}{l}\text { SaL---- } \\
\text { to white. }\end{array}$ & $\begin{array}{l}\text { mmsab to } \\
\text { mcpl. }\end{array}$ & $\begin{array}{l}\text { vss, } \\
\text { vsp. }\end{array}$ & ---do..-- & --do.---- & $\begin{array}{l}\text { Hard to firm when dry; gradual, } \\
\text { smooth boundary. }\end{array}$ \\
\hline T4-1n--- & $145-162-$ & $11 \mathrm{~K} 31 \mathrm{~b}---$ & $\frac{5 Y R 8 / 1 d}{\text { to white. }}$ & $\operatorname{SaL}(-)-$ & mmsab--- & $\begin{array}{l}\text { vss, } \\
\text { vsp. }\end{array}$ & ---do."-- & $\begin{array}{l}\text { m-w stg } \\
\text { III. }\end{array}$ & $\begin{array}{l}\text { Carbonate nodules engulfed in } \\
\text { calcareous matrix; abrupt, } \\
\text { wavy boundary. }\end{array}$ \\
\hline T4-10--- & $162-180-$ & $11 \mathrm{~K} 32 \mathrm{~b}---$ & $\begin{array}{l}7.5 \mathrm{YR} 6.5 / 4 \mathrm{~d} \\
7.5 \mathrm{YR} 6.5 / 6 \mathrm{~m} .\end{array}$ & LSa---- & $\begin{array}{l}\text { wmsab, } \\
\text { sg. }\end{array}$ & $\begin{array}{l}\text { vss, } \\
\text { po. }\end{array}$ & None----- & $\begin{array}{l}\text { VW stg III } \\
\text { to s stg } \\
\text { II. }\end{array}$ & $\begin{array}{l}\text { Carbonate nodules slightly cemented; } \\
\text { clear, wavy boundary. }\end{array}$ \\
\hline T4-1p--- & $180-205-$ & $11 \mathrm{Clcab}-$ & $\begin{array}{r}7.5 Y \mathrm{YR} 6.5 / 4 d \\
7.5 \underline{Y R} 8 / 1 \mathrm{~d}\end{array}$ & $\operatorname{LSa}(+)-$ & $\begin{array}{l}\text { wmsab, } \\
\text { sg. }\end{array}$ & so, & None----- & $\begin{array}{l}\text { m stg II, } \\
\text { stg I } \\
\text { matrix }\end{array}$ & $\begin{array}{l}\text { 20-percent carbonate nodules in } \\
\text { light-brown sand; gradual, wavy } \\
\text { boundary. }\end{array}$ \\
\hline$T^{4}-1 q---$ & $205-220+$ & $11 \mathrm{c} 2 \mathrm{cab}--$ & $\begin{array}{r}6.7 \mathrm{YR} 5.5 / 5 \mathrm{~d} \\
7.5 \underline{\mathrm{YR}} 8 / 1 \mathrm{~d}\end{array}$ & $\operatorname{LSa}(+)-$ & sg-an- & so, & None----- & $\begin{array}{l}\text { m stg II, } \\
\text { matrix } \\
\text { noncal- } \\
\text { careous. }\end{array}$ & $\begin{array}{l}\text { 10-percent carbonate nodules in } \\
\text { reddish-brown sand; base covered. }\end{array}$ \\
\hline
\end{tabular}


The total content of calcium carbonate in soil Y ranges from 32 to $42 \mathrm{~g} / \mathrm{cm}^{2}$ and averages about $39 \mathrm{~g} / \mathrm{cm}^{2}$. Although the underlying Cca horizons of soil Y (unit 12) were not sampled in detail, they are slightly calcareous and 25 to $75 \mathrm{~cm}$ thick. These horizons probably contribute an additional $1-6 \mathrm{~g} / \mathrm{cm}^{2}$ to the total carbonate content of soil $Y$. (This estimate is based on horizon development and laboratory data from spot samples.) Therefore, the total calcium carbonate content of soil Y (profile T4-1, lower part) probably averages between 40 and $45 \mathrm{~g} / \mathrm{cm}^{2}$. Assuming that the primary calcium carbonate content was about 1 percent, no more than about $2.0 \mathrm{~g} / \mathrm{cm}^{2}$ of the total is a primary component; the remainder, $38-43 \mathrm{~g} / \mathrm{cm}^{2}$, is secondary calcium carbonate.

Using the same rate of carbonate accumulation as for soil $M$ at trench 3 (that is, $0.22 \pm 0.02 \mathrm{~g} / \mathrm{cm}^{2} / \mathrm{ka}$ ), the secondary carbonate in soil $\mathrm{Y}$ would have required $190,000 \pm 30,000$ years to accumulate. This amount of time is consistent with the overall development of the $\mathrm{B}$ and $\mathrm{K}$ horizons, compared to other soils in the region (Bachman and Machette, 1977; Machette in Hawley, 1978; Gile and Grossman, 1979; Machette, 1985). For the sake of further discussion, soil $\mathrm{Y}$ is considered to have formed during the past 200,000 years but was buried at the end of the Pleistocene, about $10 \mathrm{ka}$ ago by eolian sand (unit 5).

The lower part of soil $Y$ consists of various subhorizons of the 12Cca horizon. Below soil $\mathrm{Y}$ are the basal part of unit 12 and units 13 and 14 (medium- to coarsegrained alluvium). Unit 14 filled a channel in the underlying unit, 15 , which contains a moderately well developed buried soil (soil Z). Soil Z was best preserved in the southern wall of trench 4 where it has four horizons: the 15Btca, 15K, 15Cca, and 16Coxca. Erosion of soil $\mathrm{Z}$ prior to deposition of unit 14 removed the $15 \mathrm{Bt}$ horizon and left only its calcareous subhorizons along the northern side of the trench. Soil $Z$, although not quite as developed as the younger soil $\mathrm{Y}$, clearly marks a lengthy period (that is, $100,000-200,000$ years) of surface stability during the middle Pleistocene. The stratigraphically lowest unit is the 16 Coxca horizon of soil $\mathrm{Z}$, a slightly oxidized and calcareous sandy alluvium that is exposed only on the upthrown side of the westernmost fault.

The westernmost fault $(9.4 \mathrm{~m}$ from the headwall, $\mathrm{pl}$. 1D) has an impressive, irregular but nearly vertical plane that truncates units 13-16 (fig. 10). This fault is on the western edge of a narrow zone of five subparallel faults (9.4 to $10.5 \mathrm{~m}$ east of the headwall). Within this zone, units 12-14 have been dragged and sheared, and then raveled into open fissures. Among these faults, those bounding the fault zone (at 9.4 and $10.5 \mathrm{~m}$ from the headwall, pl. 1D) have the most throw. East of $10.5 \mathrm{~m}$, units 9 and older were not exposed in the trench. The

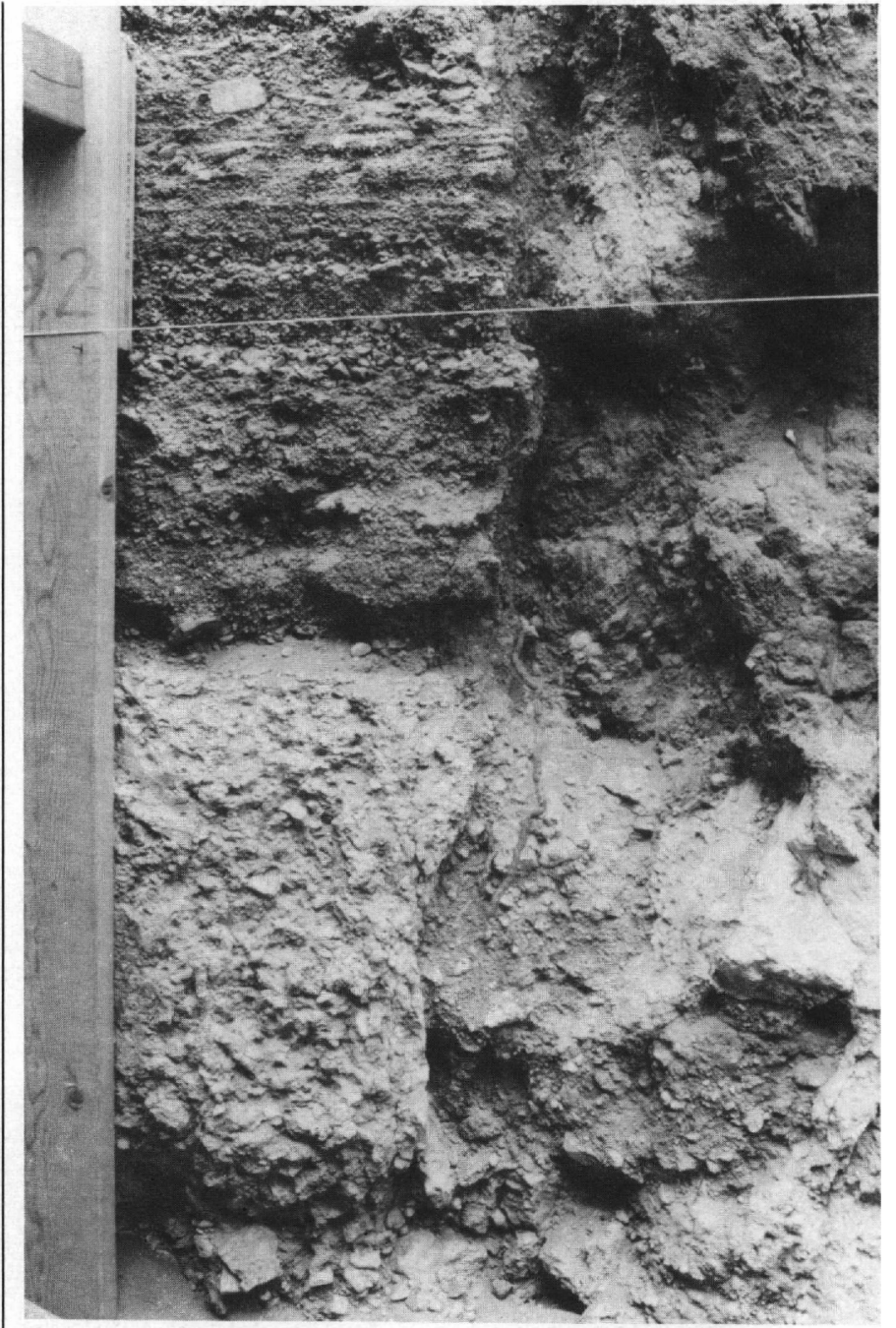

Figure 10.- Fault cutting units 13-16 in trench 4, La Jencia fault. Soil $\mathrm{Z}$ is prominent light-colored ledge below string next to shoring. View is of north trench wall. Area in photograph corresponds to part of trench 4 between 9.2 and $10.0 \mathrm{~m}$ from trench headwall (pl. 1D), and between 1.2 and $2.8 \mathrm{~m}$ from level line at western end of trench. String is at $1.5-\mathrm{m}$ level (pl. 1D).

total throw on unit 9 across the fault zone cannot be measured directly, but it must be at least $4.5 \mathrm{~m}$, the distance between the base of the trench exposure and the projected top of unit 9 on the upthrown block.

The deposits exposed in the downdropped fault block consist of units 1-6 (eolian sand), unit 7 (fault-scarp colluvium), unit 8 (eolian sand?), and slump blocks of soil $\mathrm{Y}$ (units 9-12). The lowermost units, 9-16, were not exposed (in place) east of $10.5 \mathrm{~m}$ from the headwall (pl. 1D). Unit 7, fault-scarp colluvium, contains material derived from the upthrown block, the most easily recognizable of which is chunks of the $9 \mathrm{Bt}$ and $11 \mathrm{~K}$ horizons of soil Y. The stratigraphic relationships between the faulted units and relict soil Y, colluvium derived from these units, and soil $\mathrm{X}$ on colluvium suggest 
that soil $\mathrm{Y}$ was offset and buried by movement on one or more of the western faults. This episode of faulting can be no older than 200,000 years (the age of unit 9 and beginning of formation of soil Y). Because pieces of the $9 \mathrm{Bt}$ and $11 \mathrm{~K}$ horizons of soil $\mathrm{Y}$ are clearly recognizable in unit 7 (scarp colluvium), and because these chunks are much less developed in comparison to the relict soil $\mathrm{Y}$, the age of the old episode of faulting is here considered to be slightly younger than the age of unit $9(200,000$ years).

Soil $X$ is on scarp colluvium (unit 7) and eolian sand (unit 6) that was deposited after the old episode of faulting. Soil $X$ is similar to but less developed than relict soil Y. These two soils have similar thicknesses of $\mathrm{Bt}$ and $\mathrm{K}$ horizons, ped structure, color, morphology, and content of carbonate (tables 14 and 15). The total carbonate content of soil X is about $36 \mathrm{~g} / \mathrm{cm}^{2}$ (based on the lower part of profile T4-21, table 15); this value is about 80-90 percent of the average total carbonate content of relict soil $Y\left(40-45 \mathrm{~g} / \mathrm{cm}^{2}\right)$. This comparison suggests that the two soils (relict-soil $Y$ and buried-soil $X$, pl. 1D) are close in age and that the colluvium on which soil $\mathrm{X}$ formed resulted from faulting that occurred in the early stages of formation of soil Y. If the estimate of 190,000 years for formation of soil $\mathrm{Y}$ is reasonable, then a value of 150,000 years is also reasonable for the formation of buried-soil $X$ (this value is about 80 percent of 190,000 years). The faulting that downdropped soil $\mathrm{Y}$ had a minimum offset of $1.5 \mathrm{~m}$ (the thickness of the resultant colluvium, unit 7). A deeply buried component of soil Y must have formed after deposition of unit 9 and before the old episode of faulting, an interval of perhaps 40,000 years. Although not exposed in the shallow excavation of the downdropped fault block, this soil is inferred to be moderately well developed.

The next younger episode of fault movement at trench 4 is recorded by displacement of unit 5 . At the eastern end of the trench (between 10.5 and $13.0 \mathrm{~m}$ from the headwall, pl. 1D), six to eight faults and minor fault splays cut the 5Bt horizon of soil $\mathrm{W}$, and one even displaces the 4B horizon of soil $\mathrm{V}$. These faults are direct evidence of Holocene fault activity at trench 4 . Net displacement of the base of unit 5 across this zone is about $1.25 \mathrm{~m}$.

The displacement of the $5 \mathrm{Bt}$ horizon of soil $\mathrm{W}$ must largely postdate its formation during the Holocene. The best evidence of fault timing is found in the soil's differential development in buried and relict positions. On the upthrown side of the fault near the headwall of trench 4, relict-soil $W$ is on a 3/4-m-thick layer of eolian sand. Here, the soil has an impressive Bt horizon considering that it must have formed in the past 10,000 years. At the eastern end of the trench, and especially between 10.5 and $12.0 \mathrm{~m}$ from the trench headwall, unit 5 is thinner, and soil $W$ appears to contain less secondary clay and weak ped structure (samples T4-21b-f, table 15). The apparent weak development of buried-soil W might suggest that it was buried early rather than late in its history. However, the apparent weak development of buried soil $W$ compared to its surface equivalent is probably due to the thinness of unit 5 . Some of the translocated clay that normally would have accumulated within soil W, had unit 5 been thicker, has instead moved through unit 5, adding to the overall clay content of the underlying soil (soil $\mathrm{X}, 6 \mathrm{Bt}$ horizon).

Evidence of translocation of clay to depths of more than $1 / 2 \mathrm{~m}$ (through buried-soil $\mathrm{W}$ ) is present east of the easternmost fault in trench 4 (near $13 \mathrm{~m}$ from the headwall, pl. 1D). Because unit 5 was deposited on the leeward side of a small(?) preexisting scarp, it is considerably thicker $(100$ to $110 \mathrm{~cm}$ ) here than anywhere in the trench. Laboratory data for buried-soil W (samples T4-22 $\mathrm{c}$ and d, and T4-8, table 16) show that pedogenic clay has accumulated as much as $90 \mathrm{~cm}$ below the top of the 5Bt horizon; this is well below the normal depth of clay accumulation in Holocene soils under a semiarid climate (Gile, 1975, 1977). The clay content in the basal part of soil W (5B3tcab subhorizon) is about 12 percent compared with only 6 to 7 percent in the upper part of the soil (5B1b subhorizon). Although only a few samples were taken from the lower part of soil $\mathrm{W}$, the laboratory data suggest that clay has been translocated through thin parts of unit 5 and translocated deep into thick parts of unit 5 .

If the above interpretation of deep clay translocation in buried-soil W is correct, then this mechanism explains the apparent weak development of buried-soil W. Considering the amount of pedogenic clay that was translocated through the now-buried component of soil $\mathrm{W}$, the buried and surface soils actually reflect similar degrees of development (soil W, upper part of profile T4-21 and lower part of profile T4-22, tables 15 and 16). Carbonate development, soil structure, and colors in the two soils are largely equivalent. The primary differences are in the thickness of the Bt horizon and the depth of the maximum accumulation of pedogenic clay. If relict-soil W is about $10 \mathrm{ka}$ old, then its buried equivalent clearly must have been at the surface (forming) until sometime late in the Holocene.

The episode of late Holocene faulting postulated above also is consistent with the displacement of unit 4 (pl. 1D). The lack of substantial soil development in this and higher units (1-3) indicates fairly recent deposition. Soil V (4Bb horizon, table 16 ) is the least developed and youngest soil exposed in trench 4 . The $4 \mathrm{Bb}$ horizon has 4 percent clay in the less- than- 2-mm fraction, 2 percent more than the $4 \mathrm{Cnb}$ horizon. This slight increase of clay has given the $4 \mathrm{Bb}$ horizon a weak ped structure and a friable consistence (compared to the loose consistence of the $4 \mathrm{Cnb}$ horizon, table 16 ). The $25-$ to $40-\mathrm{cm}$-thick 
TABLE 15.-Laboratory data for soil $W$ (unit 5) and soil $X$ (units 6 and 7), profile T4-21, trench 4, La Jencia fault

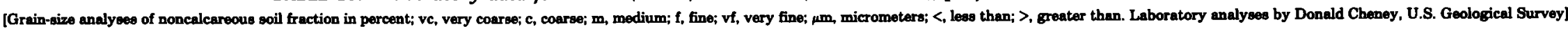

\begin{tabular}{|c|c|c|c|c|c|c|c|c|c|c|c|c|c|c|c|c|}
\hline \multirow{2}{*}{$\begin{array}{l}\text { Grain-size } \\
\text { Grain-size }\end{array}$} & \multirow{2}{*}{\multicolumn{2}{|c|}{$\begin{array}{l}\text { classes } \\
\text { categories }\end{array}$}} & \multicolumn{3}{|c|}{$<2-\mathrm{mm}$ fraction } & \multicolumn{5}{|c|}{ Sand $(\mathrm{mm})$} & \multicolumn{2}{|c|}{ Silt $(\mu \mathrm{m})$} & \multicolumn{2}{|c|}{$\mathrm{Clay}(\mu \mathrm{m})$} & \multicolumn{2}{|c|}{ Whole sample } \\
\hline & & & Sand & Silt & Clay & vo & $\mathrm{c}$ & $\mathrm{m}$ & $f$ & $\mathrm{vf}$ & $\mathrm{c}$ & $f$ & $\mathrm{c}$ & $\bar{f}$ & & \\
\hline Grain sizes & $3(\mathrm{~mm})--$ & $\ldots$ & $(2.0)$ & $(0.05-$ & $(<0.002)$ & $(2-1)$ & $(1-0.5)$ & $\left(0.5^{-}\right.$ & $(0.25-$ & $(0.1-$ & $(50-20)$ & $(20-2)$ & $(2-0.5)$ & $(<0.5)$ & $(<2 \mathrm{~mm})$ & $(>2 \mathrm{~mm})$ \\
\hline $\begin{array}{c}\text { Sample } \\
\text { No. }\end{array}$ & $\begin{array}{l}\text { Depth } \\
(\mathrm{cm})\end{array}$ & $\begin{array}{l}\text { Horizon or } \\
\text { subhorizon }\end{array}$ & 0.05 & $0.002)$ & & & & $0.25)$ & $0.1)$ & $0.05)$ & & & & & & \\
\hline T4-21a-- & $0-11 \cdots$ & 3Cnb- $\cdots$ & 89.8 & 6.7 & 3.5 & 0.7 & 3.4 & 21.7 & 55.9 & 8.1 & 2.0 & 4.7 & 2.6 & 0.9 & 99.4 & 0.6 \\
\hline$T 4-21 \mathrm{~b}--$ & $11-22-\cdots$ & $5 \mathrm{~B} 1 \mathrm{~b}-\cdots$ & 83.7 & 11.6 & 4.7 & .4 & 2.2 & 19.1 & 53.6 & 8.2 & 6.1 & 5.5 & 2.8 & 1.9 & 99.4 & .6 \\
\hline$T 4-21 c--$ & $22-35-\cdots$ & $5 B 21 \mathrm{tb} \cdots$ & 82.9 & 10.7 & 6.4 & .5 & 2.2 & 17.3 & 49.9 & 13.1 & 5.1 & 5.6 & 2.7 & 3.7 & 99.2 & .6 \\
\hline T4-21d-- & $35-48-\cdots$ & $5 B 22 t b--$ & 74.9 & 15.2 & 9.9 & .4 & 2.0 & 13.4 & 46.0 & 12.9 & 8.7 & 6.5 & 3.6 & 6.3 & 96.0 & 4.0 \\
\hline T4-21e-- & $48-61---$ & 5B23tcab-- & 79.3 & 11.3 & 9.4 & .7 & 1.7 & 7.3 & 42.5 & 20.9 & 6.4 & 3.9 & 4.2 & 5.2 & 99.4 & .6 \\
\hline$T 4-21 \mathrm{f}--$ & $61-76-\cdots$ & 5B3tcab--- & 74.9 & 17.9 & 8.2 & .7 & 2.0 & 13.8 & 42.5 & 15.1 & 11.1 & 6.8 & 3.5 & 4.7 & 98.7 & 1.3 \\
\hline T4-21g-- & $76-89--$ & $6 \mathrm{~B} 21 \mathrm{tb}-\cdots$ & 74.2 & 7.7 & 19.1 & 1.4 & 3.0 & 14.4 & 44.8 & 9.6 & 6.0 & 1.7 & 4.0 & 15.1 & 98.6 & 1.4 \\
\hline T4-21h-- & $89-102--$ & 6B22tcab-- & 65.6 & 8.1 & 26.3 & .9 & 2.7 & 14.4 & 41.6 & 6.0 & 2.4 & 5.7 & 4.4 & 21.9 & 99.8 & .2 \\
\hline T4-211-- & $102 \div 111-$ & $7 \mathrm{~K} 1 \mathrm{~b} \cdots \cdots$ & 65.9 & 14.6 & 19.5 & 1.0 & 2.9 & 16.2 & 35.7 & 10.1 & 6.6 & 8.0 & 6.6 & 12.9 & 99.1 & .9 \\
\hline T4-21j-- & $111-128-$ & $7 \mathrm{~K} 22 \mathrm{~b}-$ & 56.4 & 16.3 & 26.8 & .8 & 2.4 & 12.8 & 30.7 & 10.5 & 7.8 & 8.5 & 8.5 & 18.3 & 99.3 & .7 \\
\hline T4-21k-- & $128-147-$ & $7 \mathrm{~K} 23 \mathrm{~b}-\cdots$ & 58.5 & 19.9 & 21.6 & .9 & 2.5 & 11.8 & 34.1 & 9.2 & 10.4 & 9.5 & 9.6 & 12.0 & 99.4 & .6 \\
\hline T4-211-- & $147-172-$ & $7 \mathrm{~K} 3 \mathrm{~b} \cdots$ & 67.0 & 23.6 & 9.4 & 2.0 & 3.3 & 11.9 & 37.7 & 12.0 & 8.3 & 15.3 & 7.4 & 2.0 & 96.5 & 3.5 \\
\hline
\end{tabular}

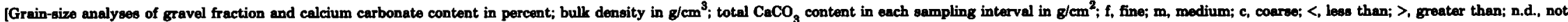
determined; Do., ditto. Laboratory analyseeo by Donald Cheney, U.S. Geological Survoy]

\begin{tabular}{|c|c|c|c|c|c|c|c|c|c|c|}
\hline \multirow[b]{2}{*}{$\begin{array}{l}\text { Grain-size categories } \\
\text { Grain sizes (mm)---- } \\
\text { Sample No. }\end{array}$} & \multicolumn{3}{|c|}{ Gravel (>2 mm) } & \multirow[b]{2}{*}{$\mathrm{pH}$} & \multicolumn{2}{|c|}{ Bulk density } & \multicolumn{2}{|c|}{$\mathrm{CaCO}_{3}$} & \multirow{2}{*}{$\begin{array}{l}\text { Total } \\
\text { CaCos } \\
\text { content }\end{array}$} & \multirow[b]{2}{*}{ Texture } \\
\hline & $\frac{f}{(2-19)}$ & $\frac{m}{19-76)}$ & $\frac{c}{(>76)}$ & & $<2 \mathrm{~mm}$ & $\begin{array}{l}\text { Whole } \\
\text { sample }\end{array}$ & $<2 \mathrm{~mm}$ & $\begin{array}{l}\text { Whole } \\
\text { sample }\end{array}$ & & \\
\hline $\begin{array}{l}\text { T } 4-21 \mathrm{a} \\
\text { T } 4-21 \mathrm{~b} \\
\text { T } 4-21 \mathrm{c} \\
\text { T } 4-21 \mathrm{~d} \\
\text { T } 4-21 \mathrm{e} \\
\mathrm{T} 4-21 \mathrm{f} \\
\mathrm{T} 4-21 \mathrm{~g} \\
\mathrm{~T} 4-21 \mathrm{~h} \\
\mathrm{~T} 4-21 \mathrm{i} \\
\mathrm{T} 4-21 \mathrm{j} \\
\mathrm{T} 4-21 \mathrm{k} \\
\mathrm{T} 4-21 \mathrm{l}\end{array}$ & $\begin{array}{l}100.0 \\
100.0 \\
100.0 \\
100.0 \\
100.0 \\
100.0 \\
100.0 \\
100.0 \\
100.0 \\
100.0 \\
100.0 \\
100.0\end{array}$ & $\begin{array}{l}0.0 \\
.0 \\
.0 \\
.0 \\
.0 \\
.0 \\
.0 \\
.0 \\
.0 \\
.0 \\
.0 \\
.0\end{array}$ & $\begin{array}{l}0.0 \\
.0 \\
.0 \\
.0 \\
.0 \\
.0 \\
.0 \\
.0 \\
.0 \\
.0 \\
.0 \\
.0\end{array}$ & $\begin{array}{l}\text { n.d. } \\
\text { n.d. } \\
\text { n.d. } \\
\text { n.d. } \\
\text { n.d. } \\
\text { n.d. } \\
\text { n.d. } \\
\text { n.d. } \\
\text { n.d. } \\
\text { n.d. } \\
\text { n.d. } \\
\text { n.d. }\end{array}$ & $\begin{array}{l}\neq_{1} .6 \\
1.68 \\
1.71 \\
1.76 \\
1.68 \\
1.82 \\
1.79 \\
1.64 \\
1.40 \\
1.42 \\
1.66 \\
1.67\end{array}$ & $\begin{array}{l}\mp 1.6 \\
1.68 \\
1.71 \\
1.76 \\
1.68 \\
1.82 \\
1.79 \\
1.64 \\
1.40 \\
1.42 \\
1.66 \\
1.67\end{array}$ & $\begin{array}{r}0.3 \\
.2 \\
.2 \\
.2 \\
1.6 \\
1.4 \\
.9 \\
.5 \\
32.9 \\
50.3 \\
33.4 \\
9.0\end{array}$ & $\begin{array}{r}0.3 \\
.2 \\
.2 \\
.2 \\
1.6 \\
1.4 \\
.9 \\
.5 \\
32.6 \\
49.9 \\
33.2 \\
18.3\end{array}$ & $\begin{array}{l}\text { n.d. } \\
\text { n.d. } \\
\text { n.d. } \\
\text { n.d. } \\
\text { n.d. } \\
\text { n.d. } \\
\text { n.d. } \\
\text { n.d. } \\
5.0 \\
11.3 \\
11.0 \\
8.6\end{array}$ & $\begin{array}{l}\text { Sand plus. } \\
\text { Loamy sand. } \\
\text { Do. } \\
\text { Sandy loam minus. } \\
\text { Sandy loam minus to loamy sand plus. } \\
\text { Sandy loam minus. } \\
\text { Sandy loam plus. } \\
\text { Sandy clay loam. } \\
\text { Sandy loam plus. } \\
\text { Sandy clay loam. } \\
\text { Sandy clay loam minus. } \\
\text { Sandy loam. }\end{array}$ \\
\hline
\end{tabular}

Estimated value. 
TABLE 16.-Laboratory data for soil $V$ (unit 4) and soil $W$ (unit 5), profile T4-22, trench 4, La Jencia fault [Grain-aize analyses of noncalcareous soil fraction in percent; vc, very coarse; c, coaree; m, medium; f, fine; vf, very fine; $\mu \mathrm{m}$, micrometers; <, less than; >, greater than. Laboratory analyses by Donald Cheney, U.S. Geological Survey]

\begin{tabular}{|c|c|c|c|c|c|c|c|c|c|c|c|c|c|c|c|c|}
\hline \multirow{2}{*}{\multicolumn{3}{|c|}{$\begin{array}{l}\text { Grain-size classes--- } \\
\text { Grain-size categories-- }\end{array}$}} & \multicolumn{3}{|c|}{$<2-m m$ fraction } & \multicolumn{5}{|c|}{ Sand $(\mathrm{mm})$} & \multicolumn{2}{|c|}{ Silt $(\mu \mathrm{m})$} & \multicolumn{2}{|c|}{ Clay ( $\mu \mathrm{m})$} & \multicolumn{2}{|c|}{ Whole sample } \\
\hline & & & Sand & Silt & Clay & ve & c & $\mathrm{m}$ & $\mathrm{f}$ & vf & c & $\mathrm{f}$ & c & $\mathrm{f}$ & & \\
\hline Grain sizes & $s(m m)----$ & --n--n-- & $\left(2.0^{-}\right.$ & $(0.05-$ & $(<0.002)$ & $(2-1)$ & $(1-0.5)$ & $10.5^{-}$ & $(0.25-$ & $(0.1-$ & $(50-20)$ & $(20-2)$ & $(2-0.5)$ & $(<0.5)$ & $(<2 \mathrm{~mm})$ & $(>2 \mathrm{~mm}$ \\
\hline $\begin{array}{c}\text { Sample } \\
\text { No. }\end{array}$ & $\begin{array}{l}\text { Depth } \\
(\mathrm{cm})\end{array}$ & $\begin{array}{l}\text { Horizon or } \\
\text { subhorizon }\end{array}$ & $0.05)$ & $0.002)$ & & & & $0.25)$ & $0.1)$ & $0.05)$ & & & & & & \\
\hline $4-22 a--$ & $0-25-\cdots$ & 4Bb------- & 89.5 & 6.6 & 4.0 & 0.5 & 2.6 & 21.2 & 53.5 & 7.8 & 3.9 & 3.0 & 2.0 & 2.0 & & 0.6 \\
\hline$T 4-22 b--$ & $25-65---$ & 4Cnb----- & 93.6 & 4.3 & 2.1 & .3 & 4.2 & 22.5 & 57.0 & 9.6 & 2.7 & 1.6 & 1.3 & .8 & & .5 \\
\hline T4-22c-- & $65-95---$ & $5 \mathrm{Blb}-\cdots$ & 89.7 & 4.2 & 6.1 & .8 & 3.0 & 22.4 & 53.8 & 9.7 & 1.3 & 2.9 & 1.7 & 4.4 & 96 & 3.8 \\
\hline T4-22d-- & $95-130--$ & 5B2b------ & 83.3 & 9.6 & 7.1 & .7 & 2.7 & 18.7 & 55.4 & 7.7 & $5 . \overline{8}$ & 3.8 & 1.3 & 5.8 & & 3.1 \\
\hline T4-8---- & $130-165-$ & 5B3tcab--- & 69.2 & 19.2 & 11.6 & .5 & 1.8 & 12.3 & 40.3 & 14.2 & 12.2 & 7.0 & 3.6 & 8.0 & 98.8 & 1.2 \\
\hline
\end{tabular}

[Grain-size analyses of gravel fraction and calcium carbonate content in percent; bulk density in g/cm"; $\mathbf{f}^{3}$, fine; m, medium; c, coaree; <, less than; >. greater than; n.d., not determined. Laboratory analysee by Donald Cheney, U.S. Geological Survey]

\begin{tabular}{|c|c|c|c|c|c|c|c|c|c|}
\hline \multirow{3}{*}{$\begin{array}{l}\text { Grain size categories } \\
\text { Grain sizes (mm)--- } \\
\text { Sample } \\
\text { No. }\end{array}$} & \multicolumn{3}{|c|}{ Gravel $(>2 \mathrm{~mm})$} & \multirow{3}{*}{$\mathrm{pH}$} & \multicolumn{2}{|c|}{ Bulk density } & \multicolumn{2}{|c|}{$\mathrm{CaCO}_{3}$} & \multirow{3}{*}{ Texture } \\
\hline & $\mathrm{f}$ & $\mathrm{m}$ & $\mathrm{c}$ & & $<2 \mathrm{~mm}$ & Whole & $<2 \mathrm{~mm}$ & Whole & \\
\hline & \multicolumn{2}{|c|}{$(2-19)(19-76)$} & $(>76)$ & & sample & & sample & & \\
\hline T4-22a & 100.0 & 0.0 & 0.0 & n.d. & n.d. & n.d. & 0.2 & 0.2 & Sand. \\
\hline $\mathrm{T} 4-22 \mathrm{~b}-\ldots$ & 100.0 & .0 & .0 & n.d. & n.d. & n.d. & .2 & .2 & Sand. \\
\hline T $4-22 c-\ldots+\ldots-\ldots$ & 100.0 & .0 & .0 & n.d. & n.d. & n.d. & .2 & .2 & Sand plus. \\
\hline T4-22d-n. & 100.0 & .0 & .0 & n.d. & n.d. & n.d. & .2 & .2 & Loamy sand minus. \\
\hline 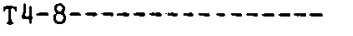 & 100.0 & .0 & .0 & n.d. & n.d. & n.d. & 1.8 & 1.8 & Sandy loam. \\
\hline
\end{tabular}


$\mathrm{B}$ horizon of soil $\mathrm{V}$ has gained $0.8 \mathrm{~g} / \mathrm{cm}^{2}$ of secondary clay. (This calculation is based on a 2-percent increase in clay, bulk density of $1.6 \mathrm{~g} / \mathrm{cm}^{3}$ and thickness of $30 \mathrm{~cm}$.) Using a clay-accumulation rate of $0.24-0.35 \mathrm{~g} / \mathrm{cm}^{2} / \mathrm{ka}$, the same rate used for relict-soil $\mathrm{W}$, the secondary clay would have accumulated in 2,500 to 3,000 years. Thus, soil $\mathrm{V}$ (and unit 4) postdates some of the recent faulting that is recorded in soil $W$ and unit 5 .

The faulting that displaced unit 5 , and in one locality unit 4, must have largely postdated the formation of soil $\mathrm{W}$ and entirely predated the formation of soil V (2.5-3 ka ago); hence it must have occurred fairly recently, perhaps 3,000 years ago at the most. This age interpretation reasonably accommodates the soil, stratigraphic, and structural relationships described in the preceding discussion.

About $3.25 \mathrm{~m}$ of even younger offset also occurred on one or more of the western faults $(9.5-10.5 \mathrm{~m}$ from the headwall) as suggested by relations between faultinduced slump blocks (mainly soil $\mathrm{Y}$ ), the $5 \mathrm{Bt}$ horizon of soil W, and the unit on which they both rest, the $3 \mathrm{Cn}$ horizon. Deposition of the slump blocks must postdate both the formation of soil V (on unit 4) and the deposition of at least part of unit 3 (eolian sand). The slump blocks rotated forward and downslope, like a set of fallen dominos, across loose eolian sand. The rotation of these blocks (pl. 1D) are evidenced by ped orientations and uniformly inclined boundaries between subhorizons.

The youngest unit exposed in trench 4 is the Cn horizon (unit 1), a loose, friable eolian sand. Unit 1 overlies the slump blocks formed during the most recent faulting (8-9.5 $\mathrm{m}$ from the headwall, pl. 1D) and postdates all faulting in trench 4 . Thus, the most recent surface faulting offset units as young as soil $\mathrm{V}$ of unit 4 in late Holocene time and produced a fairly large scarp from which blocks of soil Y slumped.

The 200,000-year-old soil $\mathrm{W}$ is offset at least $5.5 \mathrm{~m}$ along faults between 9 and $10.5 \mathrm{~m}$ from the headwall; the net offset during the Holocene has been about $4.5 \mathrm{~m}$. The faults in the eastern part of the trench displaced the base of unit 5 about $1.25 \mathrm{~m}$ in the late Holocene (about $3 \mathrm{ka}$ ? ago). The most recent faulting, which produced about $3.25 \mathrm{~m}$ of offset, must also be of latest Holocene age (less than $3 \mathrm{ka}$ ago). The oldest movement recorded at trench 4 (about $150 \mathrm{ka}$ ago) offset soil $Y$ at least $1.5 \mathrm{~m}$. Thus, 200-ka-old deposits (units 9-12) at trench 4 have been offset at least $5.5 \mathrm{~m}$ across a narrow zone of faulting during three episodes of faulting, $150 \mathrm{ka}$ ago and twice during the late Holocene.

\section{SUMMARY}

The following conclusions can be drawn from the geologic investigation at trench 4:
1. The upthrown fault block has a well-developed soil (Y) that contains both argillic and calcic horizons. On the basis of soil Y's carbonate content and overall development, it must have formed from about $200 \mathrm{ka}$ ago until the end of the Pleistocene, about $10 \mathrm{ka}$ ago (an interval of 190,000 years). Soil Y was then buried by eolian sand (unit 5) derived from desiccated beds of the upper Pleistocene San Agustin lake system. A second, older, buried soil (Z) was exposed in the upthrown fault block in trench 4. Although soil $\mathrm{Z}$ is not as well developed as the overlying soil $Y$, it does indicate a significant period of surface stability (that is, perhaps 100,000 years) during the middle Pleistocene.

2. Soil W on eolian sand contains an argillic and calcic horizon that formed during the Holocene. The average rate of accumulation of secondary clay during the past $10 \mathrm{ka}$ is $0.24-0.35 \mathrm{~g} / \mathrm{cm}^{2} / \mathrm{ka}, 1 \frac{1}{4}$ to 2 times faster than estimated from mid-Holocene soils at trench 1 . The higher rate at trench-site 4 is probably a function of its location along a dusty windgap between the Magdalena and Bear Mountains.

3. Indirect but fairly conclusive evidence points to an early episode of faulting. Soil $Y$ appears to have been downdropped at least $1.5 \mathrm{~m}$ during the early stages of its development, perhaps about $150 \mathrm{ka}$ ago. The next episode of faulting recorded in trench 4 occurred much later, during the late Holocene, indicating a long intervening period of quiescence.

4. During the late Holocene (about $3 \mathrm{ka}$ ago), soil W was offset about $1.25 \mathrm{~m}$. Evidence of the amount and timing of faulting comes from differences in development of soil W (unit 5) in buried and surface positions, from the fact that unit 4 buries slump blocks of soil W, and from the development of soil $\mathrm{V}$ on unit 4 (upper Holocene).

5. The youngest movement on faults at trench 4 offset soil $\mathrm{W}$ (unit 5) about $3.25 \mathrm{~m}$ during the late Holocene, perhaps quite recently. Collapse of the resultant fault scarp produced large coherent, composite slump-blocks of soils $W$ and $Y$ (units 9-12), which lie on unit 3. Only the two uppermost units (1 and 2) are not displaced.

6. The minimum net offset of the 200-ka-old soil $Y$ (units 9-12) is $5.5 \mathrm{~m}$. Most of this amount, about $4.5 \mathrm{~m}$, resulted from two movements of the fault during late Holocene time. Near trench 4, the present fault scarp is only about $3-3.5 \mathrm{~m}$ high because it is partly buried by eolian sand.

\section{SUMMARY OF TRENCH INVESTIGATIONS}

One of the major problems in fault investigations using trenches is the limitation of information that is essentially site specific. For example, locally controlled 
processes of erosion and deposition and differences in the properties of materials may lead to different interpretations of fault chronology even for closely spaced trenches on the same fault. Additionally, misinterpretations or miscorrelations may result in inferences of multiple fault events when, in fact, a more simplified history may be correct. Thus, it seems most reasonable to accept the simplest fault chronology that accommodates the data. It is this philosophy that was used to compile the following summary of tectonic activity along the La Jencia fault, from geologic investigation of the four trench excavations.

Key evidence for reconstructing the timing and amounts of offset on the fault lies in the soil-stratigraphic framework defined and used in mapping each trench. The soils in the study area have horizons that range from weakly developed B and Cca horizons in eolian sand and coarse-grained alluvium to strongly developed, thick, reddish, argillic B horizons and stage III calcic horizons in various alluvial and eolian materials. The La Jencia fault cuts deposits that range from late(?) Holocene age (less than $3 \mathrm{ka}$ ) to middle Pleistocene age (about $500 \mathrm{ka}$ ), but scarps along the fault are generally only 2 to $5 \mathrm{~m}$ in height. The scarps are continuous and fairly uniform in height along the entire $35 \mathrm{~km}$ of the fault, irrespective of the age of the faulted deposit.

At two of the four trench sites ( 1 and 4 ), there is abundant evidence of Holocene faulting, and two discrete late Holocene episodes are evident at trench 4 . At the two other trench sites ( 2 and 3 ), the most recent faulting occurred during the late Pleistocene, about $15 \mathrm{ka}$ ago and $33 \mathrm{ka}$ ago, respectively (table 17).

Along the central and southern parts of the La Jencia fault, the faulting in latest Pleistocene and Holocene time was preceded by at least 500,000 years of relative tectonic quiescence. Along the northern part of the fault (at trenches 3 and 4), there is indirect evidence of faulting about $150 \mathrm{ka}$ ago, but the corresponding surface offsets were probably small, a maximum of $2 \mathrm{~m}$. The present scarp along the La Jencia fault is a late Quaternary feature, the combined product of at least four separate and discrete surface ruptures separated both spacially and temporally along the fault's length.

Stratigraphic relations within colluvium derived from fault scarps generally support the sequence of scarp degradation proposed by Wallace (1977). Where soils that had well-developed $B$ and (or) $K$ horizons mantled the upthrown fault block, the trench excavations exposed large, coherent blocks of soil surrounded by a finely textured colluvial matrix just downslope from the fault; this material is termed "free-face colluvium." These blocks probably were undermined by raveling of less cohesive material from below the soil, which caused slumping of the cohesive soil mass from the fault scarp.

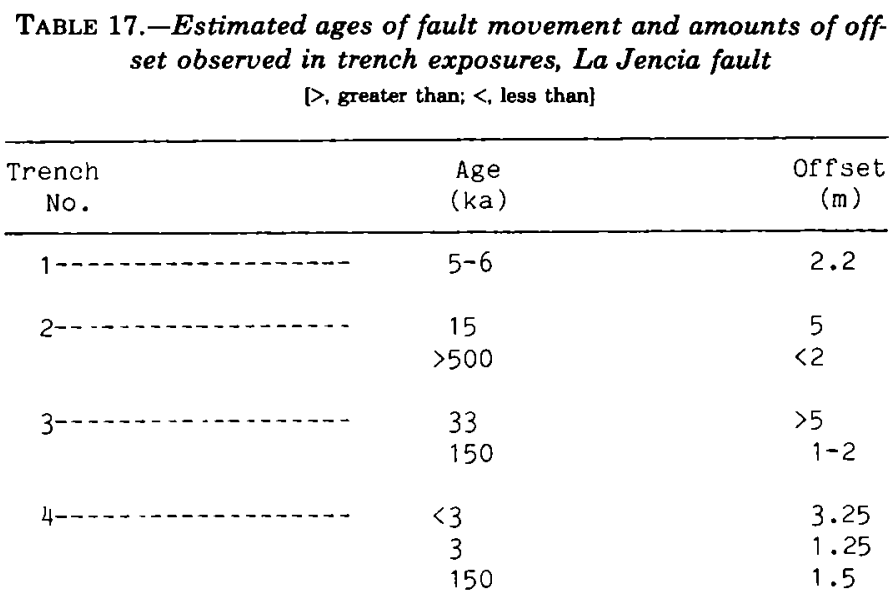

The slump blocks provided important stratigraphic and structural information that helped date episodes of movement on the fault. Later stages of scarp degradation are characterized by wash-controlled processes and result in deposits that are here termed "scarp-wash colluvium" (analogous to slope-wash colluvium). Scarpwash colluvium is derived mainly from the surface of the upthrown fault block. Where the surface of the upthown fault block is mantled by clasts having desert pavement, such as at trench-sites 1 and 2, the clasts in scarp-wash colluvium are geometrically distinct from those in free-face colluvium.

Fault-related structures exposed in the excavations include small grabens and infilled fissures, elongate pebbles and cobbles that are reoriented along the faults, and blocks tilted between faults. Most of the faults in the trenches are high-angle normal having eastward dips of $80^{\circ}-90^{\circ}$, but a steeply west-dipping reverse fault having minor offset was found in trench 1 (pl. 1A). The reverse fault probably represents a minor deviation in dip of a fault that is basically vertical in the near subsurface. The widths of fault disruption in the trenches ranged from 2.5 to $12 \mathrm{~m}$, fairly narrow zones of disturbance for such a long fault. In contrast, faulting associated with the 1983 Borah Peak earthquake (Idaho, $M_{s}$ 7.3) formed grabens that are $30-50 \mathrm{~m}$ wide in upper Pleistocene alluvium (Crone and Machette, 1984). Faulting at trench-sites 1,2 , and 4 produced double scarps (two separate surface breaks), but the present scarps give no indication of such initial geometry.

The temporal pattern of activity on the La Jencia fault during the past 500,000 years might be best generalized as one of long-term quiescence punctuated by latest Quaternary (less than $3 \mathrm{ka}$ ago to about $33 \mathrm{ka}$ ago) surface rupturing along discrete segments at different 
times. Whether or not these surface ruptures have sufficiently lowered the accumulated stress on all segments of the fault to preclude further faulting cannot be determined with certainty. Breakage seems to have occurred on all of the fault's length, and there seems to be no marked disparity in the amount of apparent offset along different parts of the fault (see discussion of fault segments in the following section on "Fault-Scarp Investigations"). This pattern of surface rupturing differs from that of the Wasatch fault zone in Utah, where some distal parts of the fault may lack Holocene movement. Gilbert (1890, p. 362) was among the first of many to suggest that these areas may indeed be preferential sites of future ground rupture.

\section{FAULT-SCARP INVESTIGATIONS}

The morphology of fault scarps, as characterized by measurements of their maximum slope angle and height (Bucknam and Anderson, 1979), constitutes a data base from which independent estimates of fault ages may be made (Nash, 1980). If scarp-height and slope-angle relationships yield evidence of fault timing concordant with the geologic investigations presented here, then scarp morphology itself is a powerful dating tool for fault studies.

Detailed site-specific studies involving trenching are costly and time consuming. If the relationships developed here for scarp height and scarp-slope angle yield a fault chronology concordant with the geologic investigations of the La Jencia fault, then ages of other fault scarps might be readily approximated using the techniques of scarp morphology. Using scarp morphology as a dating tool, maps could be made showing different ages of faults (Machette and McGimsey, 1983). These maps would be a valuable base for assessing the neotectonic history of the Rio Grande rift (Machette and Colman, 1983).

\section{INTRODUCTION}

The most obvious geomorphic expressions of surface faulting are fault scarps. These features range from old scarps that form discontinuous (dissected) rounded slopes to young scarps that form continuous sharpcrested topographic escarpments. Along the La Jencia fault the scarps vary in both size and general appearance, suggesting early in this investigation that morphology might be useful in discriminating scarps of different ages. Thus, the morphometric characterization of fault scarps, in terms of their height and maximum slope angle, gives an independent data base for comparison with investigations of trenches and surface geology.

\section{SCARP PROFILES AND MORPHOMETRIC NOMENCLATURE}

Detailed topographic profiles were made across fault scarps to determine their height and maximum slope angle. These profiles were constructed using an Abney hand level, a stadia rod, and a cloth tape. The altitude of the stadia rod was measured from a base station at intervals of $1 / 2$ to $2 \mathrm{~m}$, and new base stations were established every 6 to $10 \mathrm{~m}$. The resulting profiles are based on an accurate survey perpendicular to the trend of the scarp. The reported scarp-slope angle (in degrees) is an average of four to six measurements made adjacent to the profile traverse. Scarp height is the difference in altitude between the intersections of the projections of the upper and lower surfaces and the plane of the maximum scarp-slope angle. The definition of scarp height and the method for its graphical determination (fig. 11) are those used by Bucknam and Anderson (1979).

Surface offset (fig. 11) is here defined as the difference in altitude of the projections of the upper and lower surfaces along a vertical plane at the midpoint of the fault scarp. For near-vertical normal faults, surface offset is a close approximation of net slip (measured on the fault plane). For these faults, the surface offset is commonly less than or equal to the scarp height (fig. 12, examples 1,4 , and 5). Where a graben, back-tilt, or reverse component of drag is developed on the downthrown side of the fault (fig. 12, example 2), the surface offset is much less than the scarp height. Conversely, the amount of surface offset generally exceeds scarp height where there is

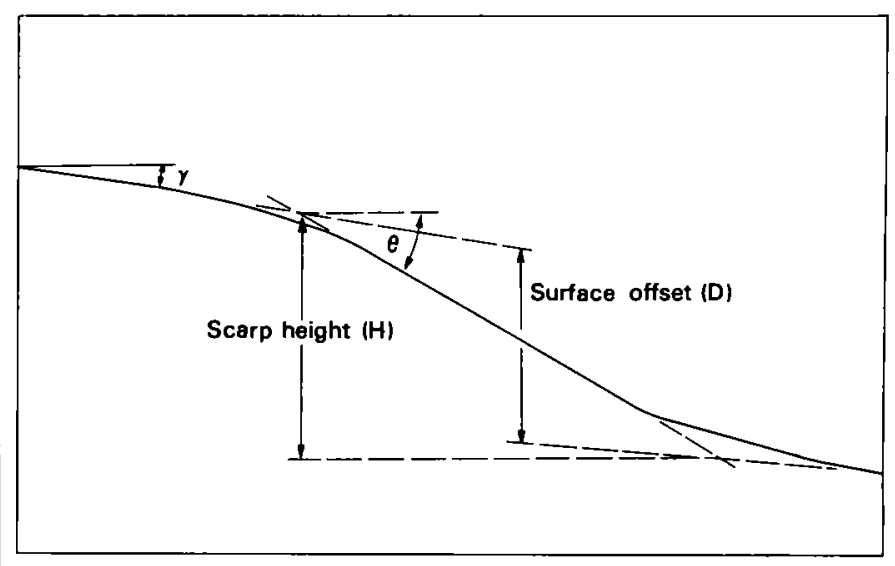

FIGURE 11.-Diagrammatic sketch of a fault-scarp profile showing graphic method of determining scarp height (H) or surface offset (D). $\gamma$, surface-slope angle; $\theta$, maximum scarp-slope angle. Modified from Bucknam and Anderson (1979, fig. 3). 


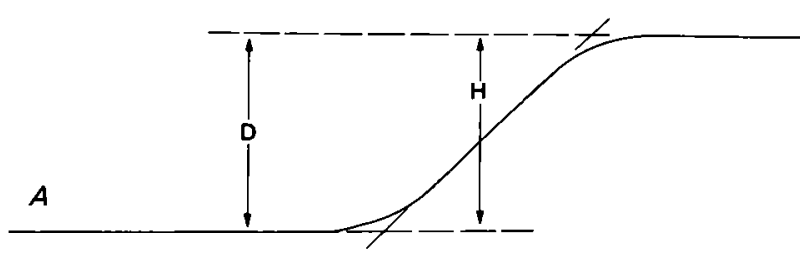

Fault displaces horizontal surface $(\gamma=0)$. Surface offset equals scarp height $(D=H)$.

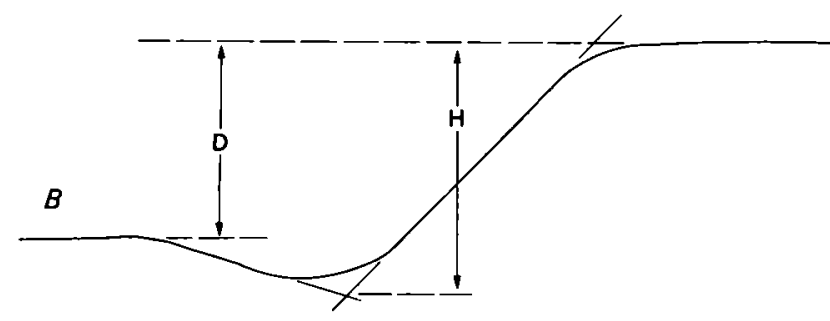

Fault displaces horizontal surface and forms half-graben at base of scarp. Surface offset is less than scarp height $(D<H)$.

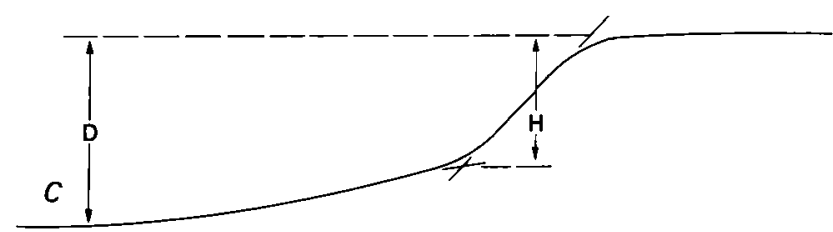

Fault displaces horizontal surface; toe of scarp is upwarped either by drag along fault or by deposition of thick colluvial wedge. Surface offset is greater than scarp height $(D>H)$.

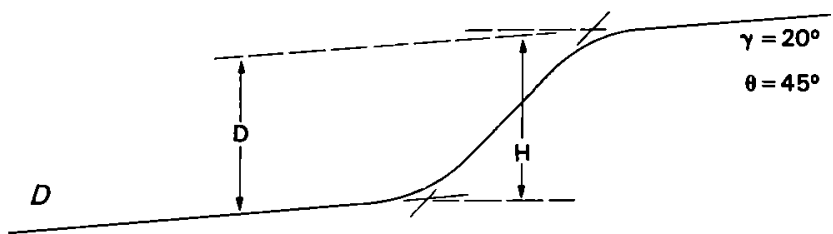

Fault displaces sloping surface, here shown exaggerated $\left(\gamma=20^{\circ}\right)$. Effect of slope is to increase scarp height relative to surface offset.

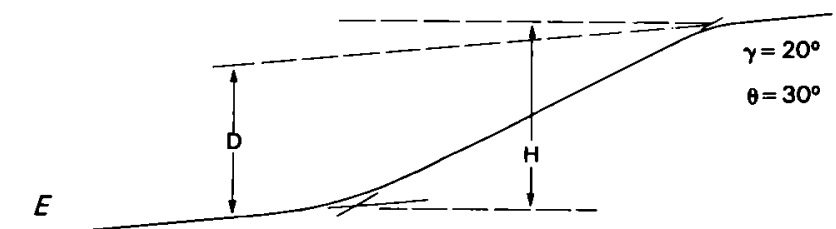

Fault displaces sloping surface (diagram D) and maximum scarp angle $(\theta)$ is greatly reduced by erosion resulting in scarps which increase in height with time (by erosion) and without further surface displacement.

FIGURE 12.-Diagrammatic sketches illustrating scarp-height and surface-offset measurements in different geomorphic settings. H, scarp height; D, surface offset; $\gamma$, surface-slope angle; $\theta$, scarp-slope angle.

substantial deposition on the downdropped block (decreasing scarp height by burial), or where the downdropped block is upwarped along the fault (fig. 12, example 3).

Natural degradational processes acting upon a fault scarp reduce the slope angle, whereas the height of the scarp may increase even though no further displace- ment has taken place (fig. 12, example 5). If the faulted surfaces are moderately to steeply sloping, the increase in scarp height solely from erosion will be even more impressive. For the La Jencia fault, the height of a scarp commonly exceeds the amount of surface offset. Scarp height is used in the following morphometric analysis, but surface offset, a closer approximation of 
displacement along the fault, is used to calculate earthquake magnitudes in the section on "Paleoseismicity of the La Jencia Fault."

\section{FACTORS AFFECTING FAULT-SCARP DEGRADATION}

The factors that control the rate of degradation of fault scarps are much like those that control rates of soil formation. These factors include the type and nature of the faulted deposits (analogous to parent material in soil formation), the position of the scarp on the landscape (topographic setting and orientation), the microclimate at the scarp, and the biotic and vegetative activity on the scarp (such as burrowing and bioturbation). It may seem that variety in these factors would prevent meaningful comparisons of scarps (or soils) from site to site, but such comparisons can be made by equalizing these factors or by determining that a factor has little differential effect upon the scarp's morphology. This approach is analagous to that commonly used in regional comparisons of soil development (Birkeland, 1974; Bachman and Machette, 1977; Machette, 1985).

In studying the La Jencia fault, all of these factors had to be considered not only for scarp morphology but in the soils investigations. Let us consider first the effect of parent material, that is, the type and nature of the faulted deposits. In a recent study of the Black Rock fault in western Nevada, Dodge and Grose $(1979,1980)$ found that grain size of faulted materials can exert strong control on rates of scarp degradation. Two scarps of equal size and age, but formed on clay versus gravel, appear grossly different in morphology; the scarp on clay is much more eroded. Grain size probably is not a critical factor for scarps on unconsolidated materials of pebbly sand or coarser texture, whereas finer size materials probably erode much faster because they are susceptible to wind erosion, sheetwash, and freezing and thawing.

Most of the scarps profiled are along the central and southern parts of the La Jencia fault, which includes trench-sites 1,2, and 3. As shown in the geologic investigation, the deposits in this part of the study area are sandy piedmont gravel having weakly developed (trench 1) to strongly developed (trench 2 and 3) soils. The deposits are uniformly coarse grained because of their proximity to the front of the Magdalena Mountains (pl. 2). Comparison of scarp profiles along the La Jencia fault shows that the limited range of these materials does not have much influence on scarp morphology. However, soils on the upthrown fault block and on the scarp itself may increase the cohesion of the scarp and slightly inhibit erosion, at least initially.
A scarp's landscape position, geomorphic setting, and aspect are other important factors that control the rate at which it will degrade. In many geologic settings, north- and south-facing hillslopes have markedly different slope angles, and by analogy, scarps of the same age having these differing orientations should have different morphologies. K. L. Pierce (1985) found that aspect (compass orientation) is an important factor for degradation of scarps along the Arco segment of the Lost River fault in Idaho. There, south-facing scarps are the most degraded, whereas north-facing scarps are the least degraded; both east- and west-facing scarps show intermediate amounts of degradation. The climate near the Arco fault site is considerably cooler than in the La Jencia basin, and freeze-thaw cycles in the Idaho soils probably cause faster scarp degradation than in the more temperate latitudes of the southwestern United States. In Utah, shorelines of the highest stand of Lake Bonneville occur in all compass orientations, but most of the well-developed shorelines face west on the leeward, eastern shore of the ancient lake (R. C. Bucknam, oral commun., 1980).

Most of the scarps I measured on the La Jencia fault face northeast (see table of scarp data on pl. 2). Two exceptions to this generality are found along segment D of the fault where a small west- to southwest-facing antithetic fault scarp forms the eastern side of a broad graben. The average aspect of the generally northeastfacing scarps I profiled along the fault segments are as follows: A, N. $53^{\circ}$ E.; B, N. $71^{\circ}$ E.; C, N. $47^{\circ}$ E.; and $\mathrm{D}, \mathrm{N} .46^{\circ} \mathrm{E}$. Most of the morphometric data is from scarps along segments $\mathrm{A}, \mathrm{B}$, and $\mathrm{C}$ (pl. 2). In this study, I have only compared scarps that have a northeastern aspect, whereas some other studies have compared scarps that face in opposing or adjacent quadrants. As previously mentioned, scarps along the northern part of the fault (segments $E$ and F) are generally covered by eolian sand, so they were not suitable for morphometric analysis.

Scarp profiles were measured only at sites where the upper and lower (faulted) surfaces were geomorphically stable, that is, areas with undisturbed soil and vegetative cover, away from active deposition or erosion. Along the Magdalena Mountains, these surfaces commonly slope eastward $3^{\circ}-6^{\circ}$; the steepest slopes are along segment $B$ (near trench 2) and along the northern part of segment $C$ (see table of scarp data on pl. 2). Elsewhere the slope of the piedmont is gentle, typically $2^{\circ}-3^{\circ}$ to the east. Within the common range of surface-slope angles, there is no apparent correlation with (dependence on) scarp morphology. However, on steeper slopes, those in excess of perhaps $6^{\circ}-8^{\circ}$, sheetwash becomes an important additional geologic process. For example, a scarp that has a maximum slope angle 
of $15^{\circ}$ and a surface slope of $10^{\circ}$ represents only a $5^{\circ}$ variation in slope angle, whereas the same scarp formed on a horizontal surface has a $15^{\circ}$ variation in slope angle. This effect is most pronounced where a degraded scarp (one having a small maximum scarp-slope angle) is formed on a surface of moderate to steep slope.

The differential effects of biotic activity and climate on scarp morphology can be dismissed easily for this study. Within the study area, the estimated meanannual temperatures and precipitations range from 9 to $12^{\circ} \mathrm{C}$ and 25 to $35 \mathrm{~cm}$, respectively. Most of the area lies within the grassland or near its margin with the juniper forest (such as at trench 2). The present vegetation and biotic associations in these areas are similar, and changes in climatic, vegetation, and biotic activity in the past probably affected all sites about the same. Therefore, temporal changes in these factors should have affected rates of scarp degradation at the sites in about the same ways. However, scarps along older (that is, late Pleistocene) segments of the fault may have been partly eroded in an environment that younger (Holocene) scarps did not have.

If a past change in climate produced significant differences in rates of degradation, the differences would be most apparent in scarps of late Pleistocene age, those which have degraded under more than one climate. Conversely, scarps of Holocene age would have degraded at more uniform rates, because of no drastic change in climate. Thus, from site to site the slight difference in present climate is not a factor, but climatically induced changes in scarp-degradation rates may be an important consideration in comparing old and young scarps. These changes in scarp-degradation rates are discussed in the section on "Rates of Scarp Degradation."

On the basis of the above arguments, scarp ages interpreted from morphology may possibly be influenced by climatically induced changes in degradation rates. Differences in topographic setting (microclimate, aspect, and surface slope), parent material, and biotic activity, the main factors that control the rate of degradation of fault scarps are considered relatively insignificant in comparisons of the morphology of scarps along the La Jencia fault.

\section{SCARP MORPHOLOGY AS AN INDICATOR OF AGE}

Three recent studies have stimulated this investigation of scarp morphology in the hope of providing another method of dating movement on the La Jencia fault. Work by Wallace (1977) in western Nevada resulted in a benchmark paper that defined processes of fault-scarp degradation and identified their dependence on age. Taking this approach one step further,
Bucknam and Anderson (1979) made detailed topographic profiles and slope measurements on scarps of different ages in Utah. These included fault scarps and both wave-cut cliffs and shorelines of the highest stand of Lake Bonneville. The lake scarps were considered by Bucknam and Anderson to have been modified by the same processes as those acting upon fault scarps. A recent review of the literature, field studies, and radiocarbon dating indicate that the highest shoreline of Lake Bonneville was formed about $15 \mathrm{ka}$ ago (Scott and others, 1983); the lake level then fell rapidly and stabilized at the Provo level, perhaps about $13.5 \mathrm{ka}$ ago. Thus, for my comparisons of scarp-profile data, the Lake Bonneville scarps are considered to be $15 \mathrm{ka}$ old. Bucknam and Anderson (1979) recognized that scarps of one age have maximum slope angles $(\theta$, in degrees, fig. 11) that are nearly linear functions of the logarithm of their heights $(\mathrm{H}$, in meters, fig. 11). For example, the shoreline scarps of Lake Bonneville have a maximum slope angle that is empirically related to height $(\mathrm{H})$ by:

$$
\theta=3.8+21.0(\log \mathrm{H}) \text {. }
$$

This equation is slightly modified (R. C. Bucknam, written commun., 1980) from one previously published by Bucknam and Anderson (1979, table 1). Equation 1 has a coefficient of determination $\left(R^{2}\right)$ of 91 percent, and the standard deviation in slope angle against height is about $1.6^{\circ}$. The log relationship closely approximates the dependence of scarp-slope angle upon scarp height between values of about 0.5 and $6 \mathrm{~m}$; however, this relation yields too large a scarp angle for small scarps. For example, in equation 1 , when $\mathrm{H}$ is $0.5 \mathrm{~m}(\log$ of $\mathrm{H}$ is $-0.3), \theta$ is $3.5^{\circ}$, a reasonable value; and when $\mathrm{H}$ is $0.1 \mathrm{~m}$ ( $\log$ of $\mathrm{H}$ is -1.0$), \theta$ is $2.5^{\circ}$. However, if $\mathrm{H}$ is $0.01 \mathrm{~m}(1 \mathrm{~cm}$, essentially no scarp; $\log$ of $\mathrm{H}$ is -2.0$), \theta$ is still $1.5^{\circ}$. Obviously, a scarp cannot have a slope angle without height; thus, the log relationship is not appropriate for small scarps (less than about $0.5 \mathrm{~m}$ high). Fortunately, in this study most of the measured scarps were between $0.8 \mathrm{~m}$ and $6 \mathrm{~m}$ high, and thus their values lie in a more reliable part of the empirically derived curve.

Nash (1980) explained the empirical relations of scarpslope angle and scarp height using a simple quantitative model of scarp degradation. This model dictates that the rate of change of elevation at a point on the scarp is proportional to curvature of the surface at that point. For young scarps having an angular profile, the model predicts that the maximum erosion will occur at the scarp's crest, and maximum deposition will occur at the scarp's toe. The model explains why old scarps have a gentler slope than younger scarps of equal height. In 1977, Nash published a study of the degradation of wave-cut cliffs in sands of Lake Michigan. He found 
that for scarps having the same maximum slope angle $(\theta$, in degrees), the age (tu) of an undated scarp of height Hu can be calculated by comparing it to a dated scarp (age td) of height $\mathrm{Hd}$, according to the following equation (modified from Nash, 1980, which contains a typographical error):

$$
\mathrm{tu}=\mathrm{td}(\mathrm{Hu} / \mathrm{Hd})^{2} .
$$

To illustrate the above relationship, consider two scarps with the same maximum-slope angle. One scarp, known to be $5 \mathrm{ka}$ old (td), is $4 \mathrm{~m}$ high (Hd). If another scarp of unknown age $(\mathrm{tu})$ is twice as high $(8 \mathrm{~m}, \mathrm{Hu})$, its calculated age (tu) is four times greater ( $20 \mathrm{ka}$ old). Equation 2 also incorporates a constant ("c value" of Nash, 1980) that describes the rate of scarp degradation $\left(\mathrm{m}^{2} / \mathrm{yr}\right.$, square meters per year); in the above example, $c$ was considered equal $\left(c_{1}=c_{2}\right)$ for both scarps and therefore was removed to simplify equation 2 .

I calculated a $\mathrm{c}$ value of $7.6 \times 10^{-4} \mathrm{~m}^{2} / \mathrm{yr}$ for the Lake Bonneville shoreline from Bucknam's data and equation 1. Nash's (1980) c value of $4.4 \times 10^{-4} \mathrm{~m}^{2} / \mathrm{yr}$ for fault scarps along the Drum Mountains, Utah, was calculated from data of Bucknam and Anderson (1979) and based on a poorly constrained age of $10 \mathrm{ka}$. The Drum Mountains fault scarps are clearly younger than the Provo shoreline of Lake Bonneville (considered to be $11.8 \mathrm{ka}$ old by Bucknam and Anderson, 1979; and about $13.5 \mathrm{ka}$ old by Scott and others, 1983). Crone's (1983) trenching study of the Drum Mountains scarps suggests an early Holocene age. If the $c$ value from the Lake Bonneville shoreline is applied to the Drum Mountains scarps, their calculated age (td) is about $5.8 \mathrm{ka}$, somewhat younger than thought by Crone (1983). This exercise shows the problem in using uncalibrated $c$ values for estimating the age of scarps. Nash (1980) used a constant value of c in his model for predicting slope angle and scarp height with age, but, as discussed previously, the rate at which scarps degrade may change with time (and climate). The potential for variable rates of degradation results in estimated scarp ages that might best be termed "model ages," unless constrained by well-dated calibration points and detailed knowledge of other factors affecting a scarp's degradation.

\section{SCARP-PROFILE DATA AND FAULT SEGMENTATION}

During the reconnaissance phase of this study, I noticed that the appearance of the scarps changed dramatically at some points along the fault, suggesting possible segmentation of the fault. After the reconnaissance and scarp profiling was finished, the La Jencia fault was

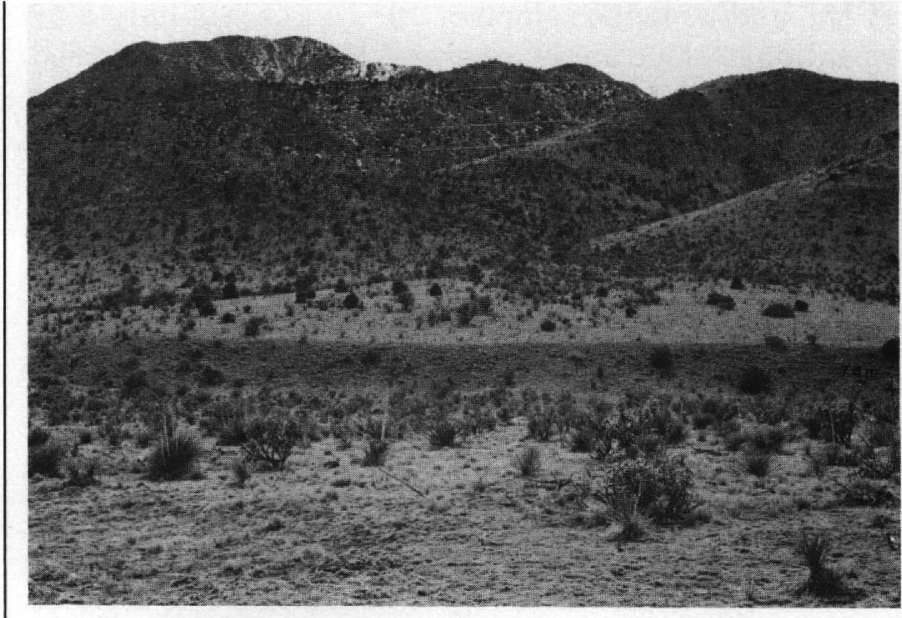

Figure 13.-Fault scarp along the northern part of segment $\mathrm{C}$ of $\mathrm{La}$ Jencia fault, just south of U.S. Highway 60 (center sec. 17, T. 2 S., R. 3 W., Magdalena 15-minute quadrangle). View to the southeast. Scarp-profile E (pl. 2, no. M1-33) was measured at right-hand margin of photograph, near juniper. Scarp is $7.4 \mathrm{~m}$ high.

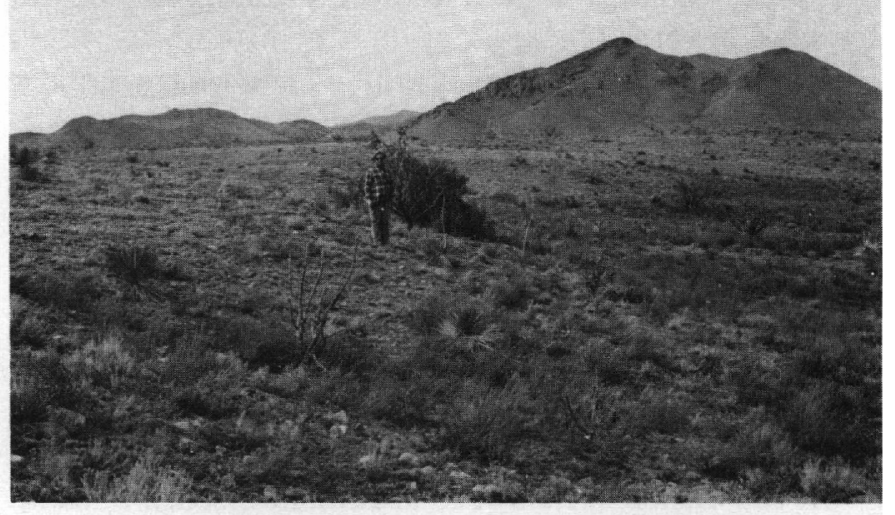

FIGURE 14.-Fault scarp along the southern part of segment $D$ of the La Jencia fault, north of U.S. Highway 60 (SE1/4 sec. 8, T. 2 S., R. 3 W., Magdalena 15-minute quadrangle). Scarp is moderately dissected by arroyos. View to the north. Note rounded toe and beveled crest of scarp, compared with sharp toe and crest of scarp shown in figure 13. Scarp-profile B (pl. 2, no. M1-28) was measured at this site.

subdivided into segments (pl. 2) on the basis of map pattern and general scarp morphology. For example, south of U.S. Highway 60 (fig. 3; secs. 17 and 20, T. 2 S., R. 3 W., pl. 2) the northwest-trending scarp (segment C) appears quite fresh. It is $4-7 \mathrm{~m}$ high and moderately steep (maximum slope angles of $24^{\circ}-25^{\circ}$ ), and has a sharp, distinct toe and crest (fig. 13). Just to the north at U.S. Highway 60 (segment D), the scarp bends abruptly $90^{\circ}$ to the right and extends several hundred meters to the north-northeast; there it strikes more to the north as far as La Jencia Creek (pl. 2). Scarps of segment D are rounded and have subdued toes and crests (fig. 14), and 


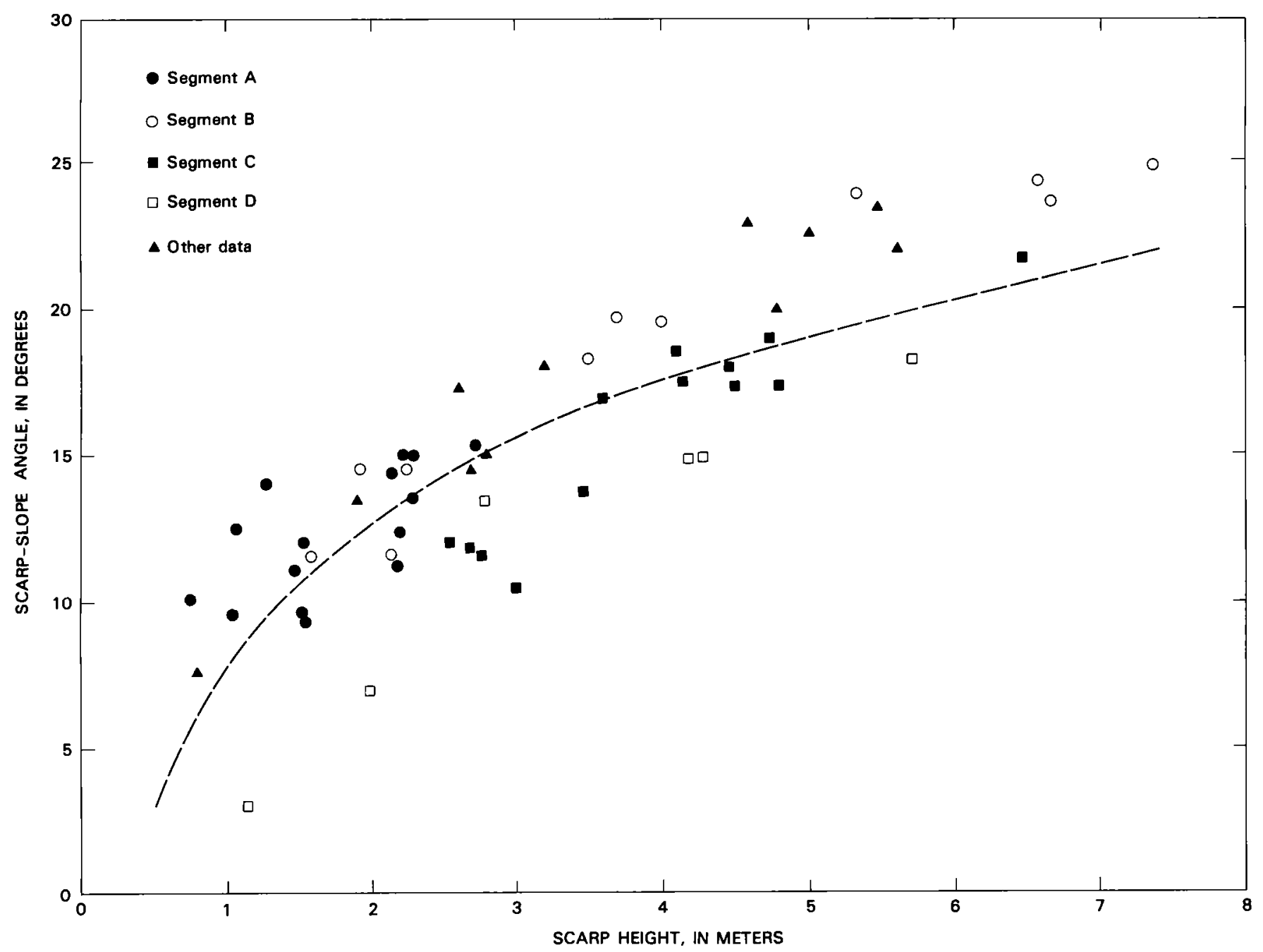

Figure 15. - Scarp-profile data for the La Jencia fault. Symbols indicate data from segments A-D of the fault (pl. 2). Data shown as solid triangles are not based on detailed topgraphic surveys and therefore are considered unreliable. Dashed line is best fit to data; regression equation for line is $\theta=7.3+17.3(\log \mathrm{H})$, coefficient of determination is 73 percent, standard deviation is $2.5^{\circ}$, and number of data pairs is 38 .

the intersection of the scarp and upper and lower surfaces (fig. 11) is obscure. These scarps range from 2.8 to $5.7 \mathrm{~m}$ in height and from $13.5^{\circ}$ to $18.5^{\circ}$ in maximum slope angle; they are not as steep as scarps of similiar height along the adjacent segment $\mathrm{C}$.

Topographic profiles were measured across the scarps of the La Jencia fault both adjacent to trench sites and in the areas between trench sites. Thirty-eight scarp profiles were measured along segments A-D of the fault, but no profiles were measured along segments $E$ and $\mathrm{F}$ owing to the extensive cover of eolian sand north of La Jencia Creek. An additional 10 measurements of scarp height and scarp-slope angle were made by less precise methods ("other data" on figure 15; see also table of scarp data on pl. 2), but these data are not used in the following computations. The scarp data from segments A-D are plotted as a composite set in figure 15. The composite data set has scarp-slope angles that range from $3^{\circ}$ to $26^{\circ}$ and scarp heights that range from 0.8 to $7.4 \mathrm{~m}$, and thus encompass a large envelope of values. Using a least-squares regression analysis, 73 percent of the variation $\left(R^{2}\right.$, coefficient of determination) in the data set is explained by the following equation:

$$
\theta=7.3+17.3(\log \mathrm{H}) \text {. }
$$

The line of best fit described by equation 3 is plotted on figure 15 , and the standard deviation in slope angle 
for any particular height of scarp is about $2.5^{\circ}$. There is considerably more variation in the composite data set $\left(R^{2}=73\right.$ percent) for the La Jencia fault than in the Lake Bonneville shoreline data $\left(R^{2}=91\right.$ percent).

For further analysis, the scarp-profile data was subdivided into four data sets corresponding to individual segments of the fault (pl. 2). Regression equations for segments A-D of the La Jencia fault are shown in table 18 , as well as equations for the Cox Ranch part of the Organ Mountains fault, New Mexico, the Utah fault scarps of Bucknam and Anderson (1979), the highest shoreline of Lake Bonneville (R. C. Bucknam, written commun., 1980), and the Arco segment of the Lost River fault, Idaho (30 ka; Pierce, 1985). Comparing the statistical data for the composite data set with the segmented data sets (table 18) shows that subdivision of the La Jencia scarp data into smaller sets for each segment produced significantly higher coefficients of determination and lower standard deviations; both measures indicate better correlation between the slope angle and height of the scarps. The scarp data from segment $D$ (near trench 3 ) is based on only five observations and thus is probably not a valid population for statistical analysis. However, the other data sets have large enough populations to be statistically valid, and their respective coefficients of determination are quite high (table 18). Thus, subdividing the scarp-profile data into separate sets, on the basis of position along the fault and of general observations of the freshness of the scarps, helps identify segments of the La Jencia fault that may have potentially different ages of scarps (and thus movement).

\section{DISCUSSION OF SCARP-PROFILE DATA}

The subdivision of scarp-profile data from the La Jencia fault yielded a significant improvement in the correlation between maximum scarp-slope angle and scarp height. In figure 16, the youngest scarps have lines of best fit that plot in the upper left part of the diagram, whereas the oldest scarps plot in the lower right part (see discussions of Bucknam and Anderson, 1979; Nash, 1980). Of the four data sets from the La Jencia fault, scarps of sets $A$ and $C$ are the youngest, and scarps of set $D$ are the oldest.

Data-set A (fault-segment A) is from low scarps mainly south of trench 1 , at the southern end of the La Jencia fault (pl. 2). The slope of the regression line A $(b=11.2$, table 18; fig. 16) is not well constrained because the scarps have a small range of height and angle $\left(0.8-2.5 \mathrm{~m}\right.$ and $\left.9^{\circ}-15.5^{\circ}\right)$. This likely is the reason for the relatively low slope (b value) of line A in comparison to those of the other scarps (table 18). The main body of data-set $A$ is centered around $1.8 \mathrm{~m}$ and $12^{\circ}$ (fig. 15), a point that is near the lower end of line $\mathrm{C}$ (a series of

TABLE 18.-Regression equations of maximum scarp-slope angle on the logarithm of scarp height [Symbols: $R^{2}$, coefficient of determination; SD, standard deviation of $\theta$ in degrees; $\mathrm{N}$, number of observations; $\theta$, maximum scarp-slope angle, in degrees; $\mathrm{H}$, scarp height, in meters; n.d., not determined]

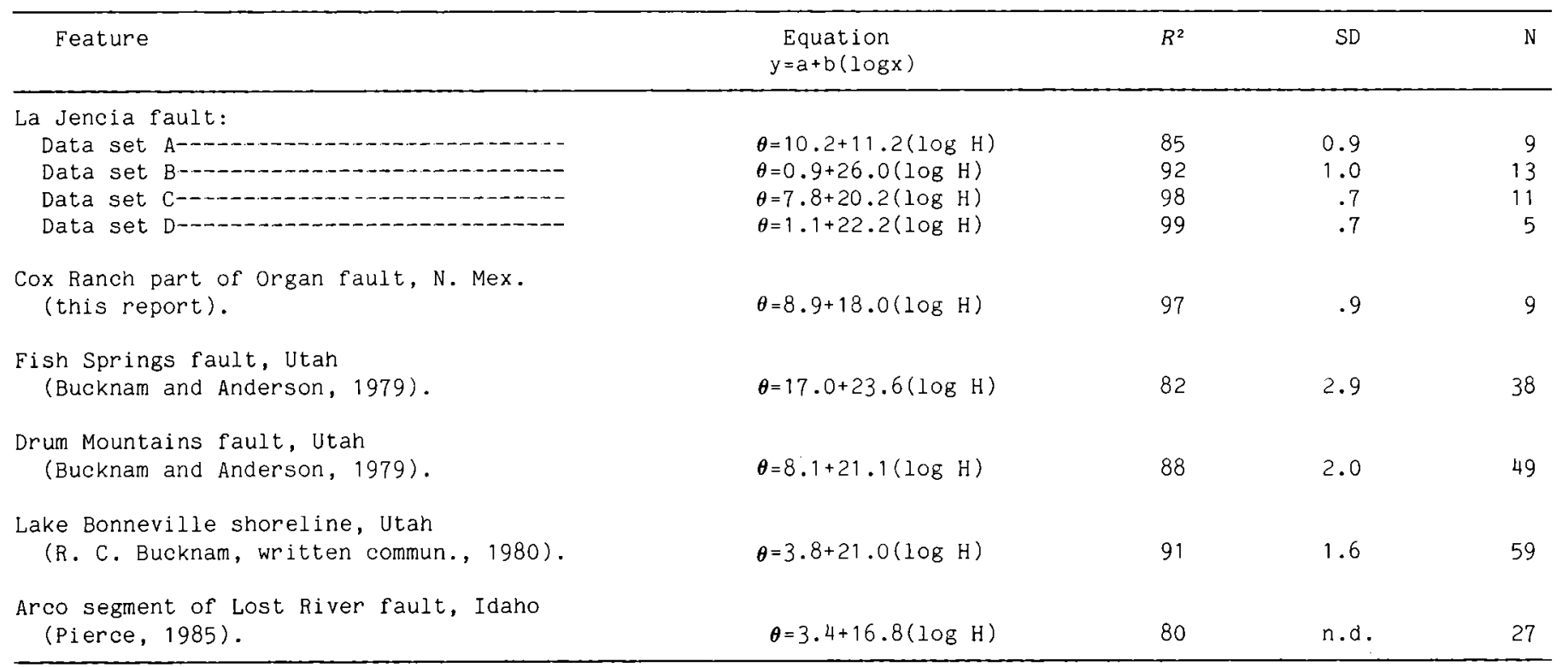




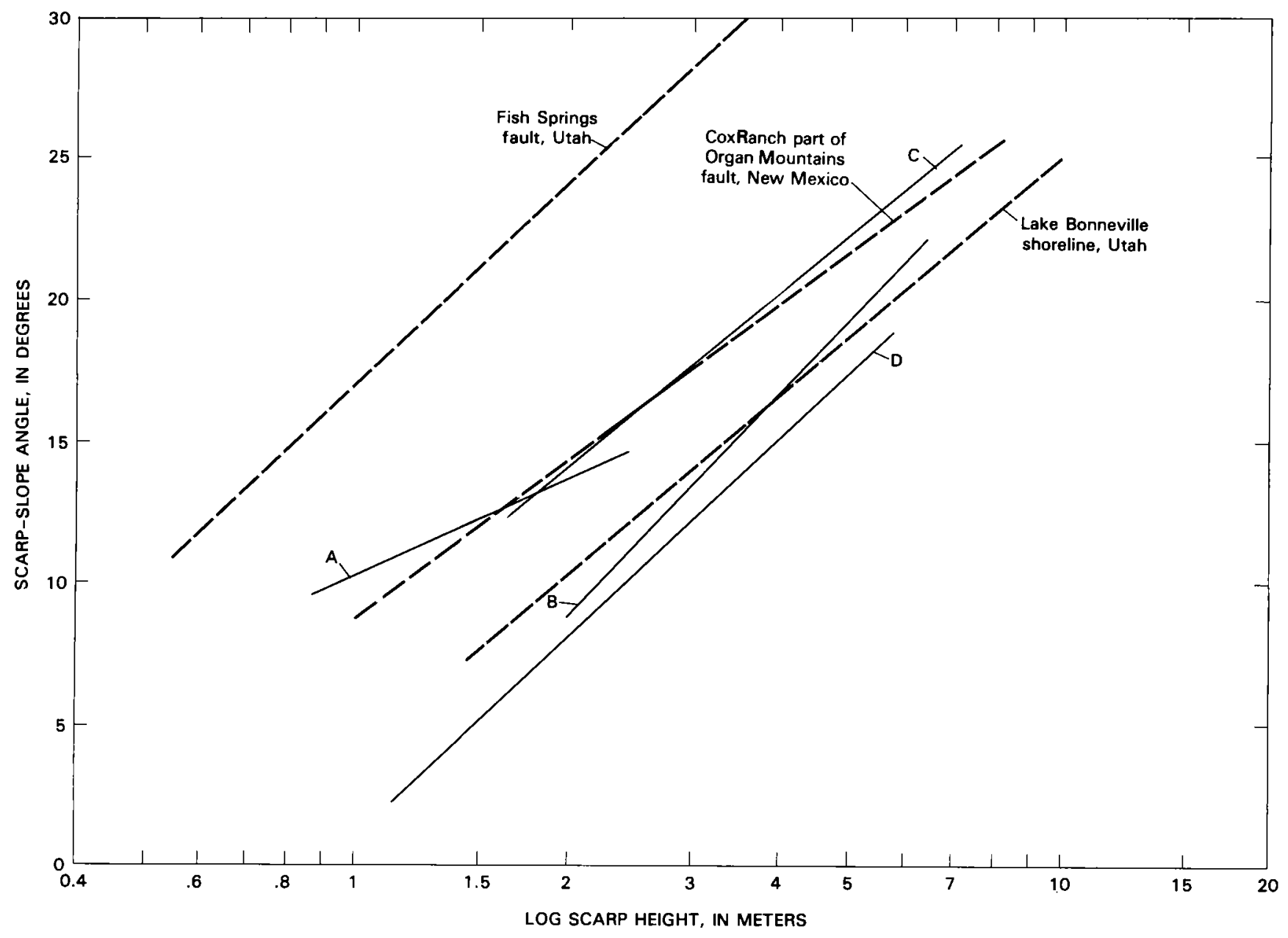

Figure 16.-Lines of best fit for scarp-profile data from segments A-D of La Jencia fault. Also shown for comparison are lines of best fit for scarps on the Cox Ranch part of the Organ fault in southern New Mexico (this report), scarps in Utah from Bucknam and Anderson (1979), and the Arco fault in Idaho (Pierce, 1985) (see table 18 for regression equations and statistical parameters).

higher, steeper scarps along segment $\mathrm{C}$ ) on figure 16. Although the range in data-set $\mathrm{A}$ is limited, its morphometric similarity to data-set $\mathrm{C}$ suggests that both sets of scarps are essentially the same age.

Data-set $\mathrm{C}$ is from scarps along fault-segment $\mathrm{C}$ between U.S. Highway 60, on the north, to near Ellis Canyon on the south (pl. 2). This data set has a very high coefficient of determination $\left(R^{2}=98\right.$ percent), a rather low standard deviation $\left(\mathrm{SD}=0.7^{\circ}\right)$, and a slope similar to that of other scarps $(b=20.2$, table 18); these three points strongly suggest that all of the scarps included in segment $\mathrm{C}$ were formed at the same time. Of the four data sets, set $\mathrm{C}$ has the least variance and the largest range of heights and angles; for these reasons, data-set $\mathrm{C}$ provides an excellent reference for morphometric comparison to other segments of the La Jencia fault and to other faults in general.
Data-set B is from scarps along fault-segment B between Water Canyon on the south and Ellis Canyon on the north (pl. 2), and includes trench-site 2. These scarps are intermediate in freshness; they are not as distinct and angular as those along segment $\mathrm{C}$ but are clearly younger and less degraded than those along segment $D$. The lines of best fit for scarp-data-sets $B$ and $D$ (lines $B$ and $D$, respectively, fig. 16) plot to the right of line $C$ (data-set C). Scarps of segment B have nearly the same morphometric characteristics as those of the highest shoreline of Lake Bonneville (table 18), but the regression equation for set $B$ has a slope (b value) of 26, which is considerably higher than all of the other scarps (table 18). Data for scarps along fault-segment $D$ plot the lowest of all the scarps on figure 16 and thus clearly represent the oldest scarps along the four segments of the La Jencia fault. 
Much of the faulted materials along segments $B$ and $D$ of the La Jencia fault have soils with well-indurated Bt and $K$ horizons that could have impeded scarp degradation. (See the sections on "Geologic Investigations" of trenches 2 and 3.) Along segment D, multiple paleosols are buried below a thin mantle of colluvium in the upper part of the scarp (trench 3, pl. 1C). These soils probably inhibited initial collapse of the scarp free face and could have influenced further scarp degradation, especially in the later stages when the scarp slope was greatly reduced. Although the surface profile at trench 3 (pl. 1C) steepens slightly above the paleosols, these moderately resistant units are, in fact, nowhere exposed on the scarp. This relation suggests that the buried paleosols are disaggregated by bioturbation and leached of calcium carbonate faster than they are removed by the processes of scarp erosion; thus, they do not form resistant layers on the scarps.

Another important point in comparing the scarp's morphologies is that scarp-degradation rates may have been appreciably higher in the recent past (in the Holocene) than during the broader span of the late Quaternary. If this relation is true, then using Nash's (1980) methods, the estimated age of a Holocene scarp would be too old if it were calculated using a pre-Holocene degradation rate, and a pre-Holocene scarp would be too young if it were calculated using Holocene degradation rates. Hence, I believe that calculated ages for the preHolocene scarps of fault-segment B, and especially for segment $D$, should be considered minimum values.

\section{AGE CALCULATIONS FOR THE LA JENCIA FAULT SCARPS}

The chronology of movement on four of the six segments (A, B, D, and E) of the La Jencia fault was determined by geologic investigation of trench exposures. Studies of fault relationships in three of the trenches provided direct age control for the scarp-morphology investigations (segments $A, B$, and $D$ ) and permit calibration of scarp-degradation rates. As previously mentioned, morphometric analysis of scarp profiles along segment $E$ was not feasible because eolian sand buries much of the scarp. Additionally, no detailed morphometric data were collected along segment $F$ because the limited geologic data suggested that movement occurred long ago, perhaps $150 \mathrm{ka}$ ago. These fault scarps are very degraded and form subtle perturbations on the piedmont slope in the northern part of the La Jencia basin; they are degraded beyond a point useful for scarpmorphology techniques.

The most recent movement on the La Jencia fault occurred during the past 3,000 years along segment $\mathrm{E}$.
Segment $A$ was the next most recently active segment of the fault and has the youngest scarps for which I made a thorough geologic investigation (no trenches were excavated across segment $\mathrm{C}$ ). Evidence from trench 1 suggests that movement on segment $A$, the youngest segment that has scarps suitable for profiling, is about $5 \mathrm{ka}$ old. Segment $\mathrm{C}$ is also considered to be about $5 \mathrm{ka}$ old, based on a comparison of the morphology of its scarps to those of segment A (fig. 16).

The next older movement on the La Jencia fault occurred along segment $B$ (which includes trench 2 ) about $15 \mathrm{ka}$ ago; this time of movement is based on the development of soils on scarp colluvium. Segment $D$ is estimated to have been most recently active about $33 \mathrm{ka}$ ago, also on the basis of soils seen in trench 4 . I consider the latter age estimate reasonably well constrained because it is based on both clay and calcium carbonate data. Segment $D$ is the oldest of the four segments for which I have scarp-profile data. Hence, for calculating the range of scarp ages by Nash's (1980) method, data from fault-segments $A$ and $D$ (the youngest and oldest) are used for reference (table 19). Ages calculated using data-set $\mathrm{C}(5 \mathrm{ka})$ are here considered as minimum ages for reasons previously explained. Alternatively, ages calculated using data-set $\mathrm{D}(33 \mathrm{ka})$ are here considered as minimum ages. The ages calculated from these two references for the intermediate-age segment $B$ are $11.2 \mathrm{ka}$ and $21.7 \mathrm{ka}$ (table 19, columns $A$ and $B$ ). Using this type of comparison, I think that the average value, about $16.5 \mathrm{ka}$, is probably a better estimate of the most probable age of scarps along fault-segment $B$.

The soils data from segment $B$ (see the section on "Geologic Investigations" for trench 2) indicate a scarp age of about $15 \mathrm{ka}$ (range of 12-18 ka), although the soil data is not well constrained. The soil data from trench 1 (segment A) and trench 3 (segment D) are better constrained and more reliable. Thus, for the following discussion, I use the ages obtained from the geologic investigations along these three fault segments as calibration for scarp-degradation rates.

\section{RATES OF SCARP DEGRADATION}

The scarp ages shown in columns $\mathrm{A}$ and $\mathrm{C}$ of table 19 suggest that scarp-degradation rates may have changed significantly from the late Pleistocene to the Holocene. Scarp ages calculated using data-set $A$ for reference (5 ka old; table 19, column A) are too young when compared with the geologic data. For example, the calculated scarp ages for segments $B$ and D (table 19, column A) are $11.2 \mathrm{ka}$ and $17.0 \mathrm{ka}$, respectively, whereas the geologic data show clearly older ages of $15 \mathrm{ka}$ and $33 \mathrm{ka}$. Thus, the average rate of scarp 
TABLE 19.-Ages of scarps calculated from Nash's model of scarp degradation and a maximum scarp-slope angle of $16^{\circ}$ [Model is from Nash (1980, equation 7). Age calculations use calibration points footnoted in columns A and B. n.d., not determined]

\begin{tabular}{|c|c|c|c|c|}
\hline \multirow[b]{2}{*}{ Location } & \multirow[b]{2}{*}{$\begin{array}{l}\text { Scarp height } \\
\text { (meters) }\end{array}$} & \multicolumn{3}{|c|}{ Scarp age (ka) } \\
\hline & & A & ${ }^{23} \mathrm{~B}$ & ${ }^{4} \mathrm{C}$ \\
\hline \multicolumn{5}{|l|}{ La Jencia fault, N. Mex.: } \\
\hline Segments $A$ and $C$ & 2.55 & ${ }^{1} 5.0$ & 9.7 & $5.0 \pm 0.5$ \\
\hline Segment $\mathrm{B}$ & 3.81 & 11.2 & 21.7 & $15.0 \pm 3.0$ \\
\hline Segment $\mathrm{C}$ & 3.29 & 8.3 & 16.2 & n.d. \\
\hline Segment $\mathrm{D}-\cdots$ & 4.70 & 17.0 & 33.0 & $33.0 \pm 6.0$ \\
\hline \multicolumn{5}{|l|}{ Cox Ranch part of Organ Mountains } \\
\hline fault, N. Mex. & 2.48 & 4.7 & n.d. & $4.0 \pm 1.0$ \\
\hline Fish Springs fault, Utaho & .90 & n.d. & .8 & n.d. \\
\hline Drum Mountains fault, Utah & 2.37 & n.d. & 5.8 & n.d. \\
\hline Lake Bonneville shoreline, Utan-.-.-- & 3.81 & n.d. & 15.0 & 15.0 \\
\hline
\end{tabular}

1 La Jencia fault: Ages in column A are based on calibration point of 5 ka for segment $A$, and

2 La Jencia fault: Ages in upper half of column B are based on calibration point of 33 ka for segment D.

${ }^{3}$ Other features: Ages in lower half of column B are based on calibration point of 15 ka for Lake Bonneville shoreline.

${ }^{4}$ Ages in column $C$ are based on soil data and stratigraphic evidence, rather than scarp morphology.

degradation along segments $\mathrm{B}$ and $\mathrm{D}$ (latest Pleistocene) appears to have been less than that along segment $A$ (and segment $\mathrm{C}$, also Holocene).

To get an idea of the magnitude of change in the rate of scarp degradation (c) needed to make the scarp ages and geologic data conform, let us assume that the degradation rate for the 5-ka-old segment $A$ applies to all of the Holocene $(10 \mathrm{ka})$. A degradation rate of $10.2 \times 10^{-4}$ $\mathrm{m}^{2} / \mathrm{yr}$ for Holocene segment A was determined by comparison with Nash's (1980) published values. Then the average degradation rate (i) for scarps of various ages was computed by comparing the heights (table 19) of scarps that have a maximum slope angle of $16^{\circ}$. I chose $16^{\circ}$ because most of the scarps on the La Jencia fault have a height at this angle that can be the product of 2-5 $\mathrm{m}$ of offset during a single surface rupture.

The long-term (average) rates of degradation $\left(\bar{c}_{1}\right)$ for scarps along segments $B$ and $D$ of the La Jencia fault are $7.6 \times 10^{-4}$ and $5.3 \times 10^{-4} \mathrm{~m}^{2} / \mathrm{yr}$, respectively (table 20). These values were computed from equation 4 (below; modified from D. B. Nash's equation 7, 1980; amended for typographical error by Nash, written commun., 1981),

$$
t_{1} / t_{2}=\left(c_{2} / c_{1}\right)\left(H_{1} / H_{2}\right)^{2},
$$

where $t_{2}=5,000$ years, $c_{2}=10.2 \times 10^{-4} \mathrm{~m}^{2} / \mathrm{yr}$ (Holocene) and $\mathrm{H}_{2}=2.55 \mathrm{~m}$ (segment $\mathrm{A}$ ); and $\mathrm{t}_{1}=15,000$ years and $H_{1}=3.81 \mathrm{~m}$ (segment $B$ ), or $t_{1}=33,000$ years and $\mathrm{H}_{1}=4.7 \mathrm{~m}$ (segment $\mathrm{D}$ ). These values are considerably less than the Holocene rate of $10.2 \times 10^{-4} \mathrm{~m}^{2} / \mathrm{yr}$.

Rates of scarp degradation for discrete intervals in the late Pleistocene can be calculated using the following step-function equation:

$$
t(\bar{c})=t_{1} c_{1}+t_{2} c_{2}+\ldots t_{n} c_{n},
$$

where $t=t_{1}+t_{2}+\ldots t_{n}$. In equation $5, t$ is the age of the scarp, $t_{1}$ is the length of time $(10,000$ years, Holocene) the scarp degrades at rate $c_{1}$, and so forth for older intervals. The average rate $\left(c_{2} \ldots c_{n}\right)$ at which scarps degraded during the late Pleistocene was calculated by applying equation 5 to scarps on fault-segments $B$ and $\mathrm{D}, 15 \mathrm{ka}$ and $33 \mathrm{ka}$ old, respectively (table 19 , column C). Values of $c_{2}$, and the resulting average rates of scarp degradation $(\overline{\mathbf{c}})$, are shown in table 21.

Rates of scarp degradation versus time are shown on figure 17, which also shows, solely for illustration, the influence of an inferred climatic change from the late Pleistocene to the Holocene. This diagram is not an attempt to reconstruct paleoclimatic conditions, but illustrates scarp-degradation rates needed to explain disparities between scarp ages calculated using Nash's (1980) model and scarp ages determined from geologic investigations.

Several interesting conclusions can be drawn from the preceding calculations of scarp-degradation rates. First, the rates must have increased $300-400$ percent from the late Pleistocene to the Holocene in order to explain the disparity between soil data and calculated scarp ages. Second, the two calculated rates (table 21) for specific intervals in the late Pleistocene are similar $\left(2.4 \times 10^{-4}\right.$ and $3.2 \times 10^{-4} \mathrm{~m}^{2} / \mathrm{yr}$ ) but much less than in the Holocene. This difference suggests that the older, low rates are climatically controlled, that is, are slow because of increased vegetative cover and surface stability in the late Pleistocene. Calculation 3 in table 21 is an alternative using two different scarpdegradation rates in the late Pleistocene; it includes 
TABLE 20.-Calculations of average scarp-degradation rates for the La Jencia and Organ Mountains faults and the highest shoreline of Lake Bonneville

$\left[\bar{c}_{1}\right.$ (scarp-degradation rate) is calculated for a scarp of age $t_{1}$ and height $\mathrm{H}_{1}$ by comparing it to another scarp of known age $t_{2}$, height $H_{1}$ and $\bar{c}_{2}$ using Nesh's (1980) equation 7 : $\left.t_{1} / t_{2}=\bar{c}_{1} / \bar{c}_{2} / H_{1} / H_{2}\right)^{2}$. To determine $\bar{c}_{1}$, transform equation to: $\bar{c}_{1}=\bar{c}_{2}\left(t_{2} / t_{2}\right)\left(H_{2} / H_{1}\right)^{2}$. Known variables for 5-ka segment $C$ of La Jencia fault: $\bar{c}_{2} \times 10^{-4} \mathrm{~m}^{2} / \mathrm{yr}, t_{2}=5 \mathrm{ka}, \mathrm{H}_{2}=2.55 \mathrm{~m}$. Range in $\bar{c}_{1}$ calculated from error limits of $t_{1}$. n.d., not determined]

\begin{tabular}{|c|c|c|c|c|}
\hline Scarp & $\begin{array}{c}t_{1} \\
(k a)\end{array}$ & $\begin{array}{l}\mathrm{H}_{1} \\
\text { (m) }\end{array}$ & $\begin{array}{c}\bar{c}_{1} \\
\left(10^{-4}\right. \\
\left.\mathrm{m}^{2} / \mathrm{yr}\right)\end{array}$ & $\begin{array}{c}\text { Range } \\
\text { in } \bar{c}_{1} \\
\left(10^{-4} \mathrm{~m}^{2} / \mathrm{yr}\right)\end{array}$ \\
\hline \multicolumn{5}{|l|}{ La Jencia fault: } \\
\hline Segment B----- & $15( \pm 3)$ & 3.81 & 7.6 & $6.3-9.5$ \\
\hline Segment D-C--- & $\begin{array}{r}33(+7 \\
-5)\end{array}$ & 4.70 & 5.3 & $4.4-6.2$ \\
\hline
\end{tabular}

Cox Ranch part of Organ Mountains fault.

$$
4( \pm 1) \quad 2.48 \quad 12.1 \quad 9.7-16.1
$$

Lake Bonneville

$\begin{array}{lllll}\text { shoreline. } & 15 & 3.81 & 7.6 & \text { n.d. }\end{array}$

TABLE 21.-Three calculations of rate of scarp degradation for specific time intervals, La Jencia fault

[The following calculations of average degradation rates use a Holocene (10-ka) degradation rate $(\bar{c})$ of $10.2 \times 10^{-4} \mathrm{~m}^{2} / \mathrm{yr}$ and the following step-function equation rates over specific time intervals: $t(\vec{c})=t_{1} c_{1}+t_{2} c_{2}--+t_{p} c_{n}$; where $t$ is scarp age, $\bar{c}$ is average scarp-degradation rate, and $c_{1}, c_{2} \ldots c_{n}$, and $t_{1}, t_{2} \ldots t_{n}$ are degradation rates at specific time intervals respectively]

1. Segment $B$ :

$15,000(7.6)=10,000(10.2)+5,000\left(c_{1}\right)$, where $t=15 \mathrm{ka}$,

$\overline{\mathrm{c}}=7.6 \times 10^{-4} \mathrm{~m}^{2} / \mathrm{yr}$ (from tabie 20 ).

$c_{1}=2.4 \times 10^{-4} \mathrm{~m}^{2} / \mathrm{yr}(10,000$ to 15,000 years ago $)$.

2. Segment D:

$33,000(5.3)=10,000(10.2)+23,000\left(c_{2}\right)$, where $t=33 \mathrm{ka}$,

$\overline{\mathrm{c}}=5.3 \times 10^{-4} \mathrm{~m}^{2} / \mathrm{yr}$ (from table 20 ).

$\mathrm{c}_{2}=3.2 \times 10^{-4} \mathrm{~m}^{2} / \mathrm{yr}(10,000$ to 33,000 years ago $)$.

3. Segment $D$ :

$33,000(5.3)=10,000(10.2)+10,000(2.4)+13,000\left(c_{3}\right)$,

(alternate of calculation 2) where $c_{2}=2.4 \times 10^{-4}$

$\mathrm{m}^{2} / \mathrm{yr}(10,000$ to 20,000 years ago $)$.

$\mathrm{c}_{3}=3.8 \times 10^{-4} \mathrm{~m}^{2} / \mathrm{yr}(20,000$ to 33,000 years ago $)$.

an interval of slow degradation $\left(c_{2}=2.4 \times 10^{-4} \mathrm{~m}^{2} / \mathrm{yr}\right)$ during the last 10,000 years $\left(t_{2}\right)$ of the Pleistocene. This calculation simulates the inferred effect of a pluvial climate analogous to the maximum glacial climate of the late Pleistocene.

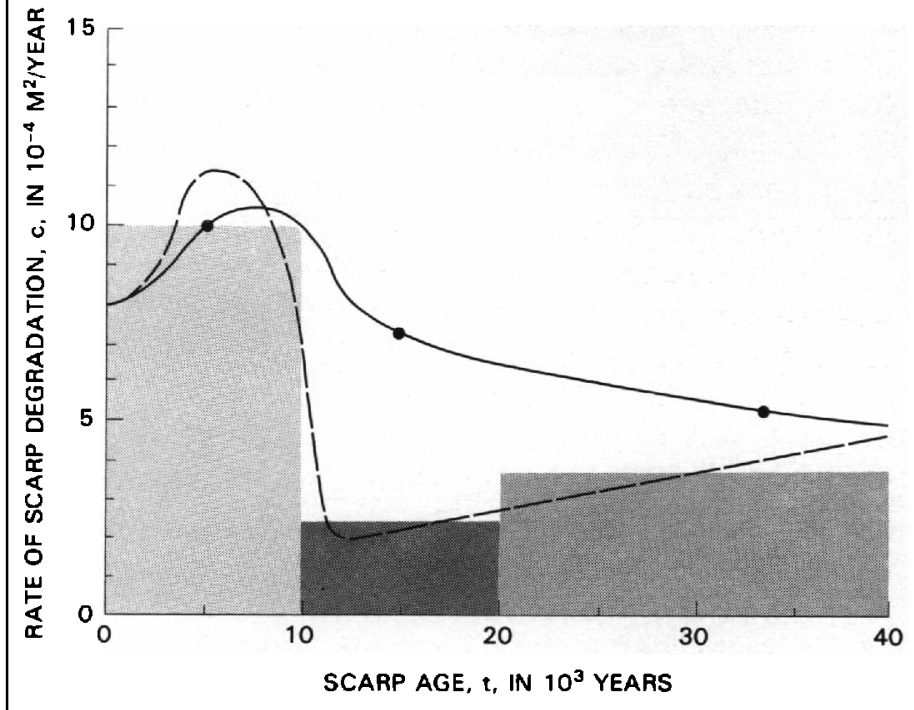

FIGURE 17.-Diagrammatic sketch of rates of scarp degradation versus age of scarp as determined from geologic investigations (see tables 20 and 21 for data). Dashed line shows hypothetical rates at any given time, whereas solid line shows resultant hypothetical cumulative rates since $t=0$. Dots are age-control points at $5 \mathrm{ka}, 15 \mathrm{ka}$, and $33 \mathrm{ka}$. Patterned blocks show rates and time intervals calculated for example 3 of table 21.

Even using the younger age limits, determined by analyses of soil development, $12 \mathrm{ka}$ for segment $\mathrm{B}$ and $28 \mathrm{ka}$ for segment $\mathrm{D}$ (table 19 , column $\mathrm{C}$ ), the corresponding rates of scarp degradation during latest Pleistocene are only $6 \times 10^{-4}$ and $4 \times 10^{-4} \mathrm{~m}^{2} / \mathrm{yr}$ (respectively), about one-half of the Holocene rate. Conversely, using the older age limits (18 ka and $40 \mathrm{ka}$, table 19 , column C) yields rates of $1.5 \times 10^{-4}$ to $2.4 \times 10^{-4} \mathrm{~m}^{2} / \mathrm{yr}$, only 15-25 percent of the Holocene rate. Thus, within the range of probable scarp ages, the late Pleistocene rates of degradation calculated from two different stepfunction equations (table 21) have to be less, and probably considerably less, than that during the Holocene. Third, even though the magnitude of change in scarpdegradation rates through time may be large (fig. 17, dashed line), these changes have less effect on the average rate $(\overline{\mathbf{c}})$ at which a scarp degrades over a long period. Dramatic changes in degradation rate (such as that associated with onset of the Holocene) have the most effect on young scarps, whereas the average rates for older scarps do not vary much because the changes are muted (fig. 17).

An interesting result of this analysis is the similarity between the computed average degradation rates $(\bar{c}$, table 20) for segment B of the La Jencia fault and for the Lake Bonneville shoreline, both of which are considered to be 15 ka old. Although both features have degraded at an average rate of $7.6 \times 10^{-4} \mathrm{~m}^{2} / \mathrm{yr}$ for the past $15 \mathrm{ka}$, the degradation rates of these two features 
may have been substantially different at any one time. Until the Holocene degradation rate is established in Utah, the age of young features such as the Fish Springs and Drum Mountains fault scarps (table 19) should not be determined solely by comparison with the Lake Bonneville shoreline data.

In New Mexico, the average degradation rate for the Cox Ranch part of the Organ Mountains fault is $12.1 \times 10^{-4} \mathrm{~m}^{2} / \mathrm{yr}$, similar to that of Holocene scarps of the La Jencia fault. However, the age for the Cox Ranch scarps is poorly constrained, and because they are so young, any refinement of their age would cause a dramatic change in average degradation rates (table 20 , range in $c_{1}$ is $9.7 \times 10^{-4}$ to $16.1 \times 10^{-4} \mathrm{~m}^{2} / \mathrm{yr}$ ). However, at the present time, Holocene scarps in these two areas of New Mexico appear to have degraded at similar rates.

\section{SUMMARY OF SCARP-MORPHOLOGY INVESTIGATIONS}

Scarp heights and maximum scarp-slope angles measured along Holocene and late Pleistocene scarps of the La Jencia fault fall into discrete groups that correspond to unique fault segments along which surface rupturing occurred at different times in the past. The pattern and timing of movement on fault segments is similiar to that developed from geologic investigations, which gives credence to scarp morphology as a relativeage dating tool in fault studies.

The following major conclusions are drawn from investigations of scarp morphology along the La Jencia fault:

1. Morphometric data for four segments of the La Jencia fault fall in three discrete groups on a diagram of scarp height versus maximum scarp-slope angle, which is a standard method of plotting such data.

2. Fault-segment A, estimated to be about $5 \mathrm{ka}$ old from geologic investigations at trench 1 , and segment C (not excavated) have the least degraded scarps. Ninety-eight percent of the total variance in morphometric data from segment $\mathrm{C}$ ( 11 data pairs) is explained by the equation $\theta=7.8+20.2(\log \mathrm{H})$. The average degradation rate $(\overline{\mathbf{c}})$ for Holocene scarps along the La Jencia fault during this interval is $10.2 \times 10^{-4} \mathrm{~m}^{2} / \mathrm{yr}$, a value which may be characteristic of the Holocene in semiarid parts of central and southern New Mexico.

3. Fault scarps of segment B, estimated to be about 15 ka old from geologic investigations at trench 2, are more degraded than those of both segments A and C, yet are less degraded than those of segment $D$. It was found that 92 percent of the total variance in data-set $B$ (13 data pairs) could be explained by the equation $\theta=0.9+26.0(\log \mathrm{H})$. The average scarp-degradation rate during the past $15 \mathrm{ka}$ is $7.6 \times 10^{-4} \mathrm{~m}^{2} / \mathrm{yr}$. Assuming that the average Holocene rate $\left(10.2 \times 10^{-4} \mathrm{~m}^{2} / \mathrm{yr}\right)$ is representative of the past $10 \mathrm{ka}$, the resultant rate for the interval from $10-15 \mathrm{ka}$ ago is $2.4 \times 10^{-4} \mathrm{~m}^{2} / \mathrm{yr}$, about one-forth of the Holocene rate. This marked slow rate of scarp degradation is explained by more extensive cover of vegetation in the late Pleistocene versus the Holocene.

4. Fault scarps of segment $D$, the most degraded of the four segments that were studied using scarp morphology, are estimated to be about $33 \mathrm{ka}$ old from soil investigations at trench 3 . Although only five scarp profiles were measured along this segment, 85 percent of the total variance in data-set $D$ is explained by the equation $\theta=1.1+22.2(\log \mathrm{H})$. The average scarp-degradation rate for the past 33,000 years is $5.3 \times 10^{-4} \mathrm{~m}^{2} / \mathrm{yr}$. As reasoned above, the resultant rate for the interval from 10,000 to 33,000 years ago is $3.2 \times 10^{-4} \mathrm{~m}^{2} / \mathrm{yr}$, only onethird the Holocene rate of scarp degradation.

5. Although the scarp-degradation rates determined here are averages and are based on ages determined mainly from soil data, they show fairly conclusive largescale differences between rates in the late Pleistocene and the Holocene. The application of a uniform scarpdegradation rate in predictive models of scarp age, such as those of Nash (1980), may lead to erroneous scarp ages if such climatically induced changes in degradation rate occur in other study areas. For example, using Holocene degradation rates (table 19, column A), scarps of segment $D$ have calculated ages of about $17 \mathrm{ka}$, almost one-half of the age determined independently from soil data.

6. The fault scarps near Cox Ranch along the Organ Mountains fault in southern New Mexico, here considered to be about $4 \mathrm{ka}$ old, are morphologically similar to those of the 5-ka-old segments $A$ and $C$ of the La Jencia fault. The average degradation rate (c) is $12.1 \times 10^{-4}$ $\mathrm{m}^{2} / \mathrm{yr}$, a value similar to the Holocene rate on the La Jencia fault. Thus, direct comparisons probably can be made between Holocene faults in different areas of New Mexico having similar geomorphic and climatic settings.

7. The average scarp-degradation rate for the past 15,000 years in central New Mexico (segment B, La Jencia fault) and in Utah (the Bonneville shoreline) is identical, $7.6 \times 10^{-4} \mathrm{~m}^{2} / \mathrm{yr}$. Whether or not the morphology of younger and older features is directly comparable in the two areas has not been established; the Holocene rates in Utah may be considerably different from those in New Mexico.

8. As a result of the combined investigations of geology and scarp morphology along the La Jencia fault, I am confident that scarp morphology can be used to discriminate different ages of fault scarps (for 
example, late Holocene from Holocene, and Holocene from late Pleistocene) on a local and regional basis (Machette and McGimsey, 1983).

\section{SUMMARY OF INVESTIGATIONS OF TRENCHES AND FAULT SCARPS}

The results of detailed investigations of trenches and surficial geology and the results from morphometric analysis of numerous profiles of fault scarps constitute two sets of data. The spatial and temporal distribution of faulting interpreted from these two data sets is essentially identical within the limits of the methods utilized, which gives extraordinary credence to the interpreted pattern of late Quaternary faulting.

This investigation shows the following pattern of activity for the La Jencia fault (table 22). The most recent ground breakage occurred in the late(?) Holocene (less than $3 \mathrm{ka}$ ago) along segment $\mathrm{E}$ of the fault (near trench 4, pl. 2) where Holocene soils are displaced about $4 \mathrm{~m}$ across a narrow zone of closely spaced faults. Somewhat earlier, perhaps about $3 \mathrm{ka}$ ago, the same soils had been offset a minor amount. Along the southernmost segment (A) of the fault (near trench 1), early to middle Holocene deposits were displaced as much as $23 / 4 \mathrm{~m}$ about $5 \mathrm{ka}$ ago. About the same time, segment $\mathrm{C}$ of the fault was active along the northern part of the Magdalena Mountains as evidenced by the scarp's young appearance in comparison to other, similar-age scarps (fig. 16). Therefore, segments $\mathrm{A}, \mathrm{C}$, and $\mathrm{E}$ of the La Jencia fault, each isolated from one another and spanning a total of $25 \mathrm{~km}$, were active a minimum of three and possibly four times during the late to middle Holocene.

A clearly older and different surface rupture occurred along segment $B$ of the La Jencia fault near trench 2. Soils formed on the scarp colluvium exposed in trench 2 are more developed than their Holocene counterparts near trench 1; calculations based on clay content in the soil on colluvium and aerosolic flux rates suggest that faulting occurred about $15 \pm 3 \mathrm{ka}$ ago on segment $B$. Along segment $B$, which is at least $8 \mathrm{~km}$ long, the fault scarp is more subdued, more dissected, and less steep than scarps of comparable heights on younger segments of the fault. Scarps on segment B have morphology similar to that of the 15-ka-old shoreline of Lake Bonneville in central Utah, which suggests that these two features have degraded at the same average rate over the past 15,000 years. Along segment $B$, the rates of scarp degradation in the latest Pleistocene (10 ka ago to $15 \mathrm{ka}$ ago) must have been about one-third to onequarter of those during the Holocene (past 10,000 years).
TABLE 22.-Lengths, maximum surface offset, and age of movement along segments of the La Jencia fault

\begin{tabular}{|c|c|c|c|}
\hline $\begin{array}{r}\text { Fault segments } \\
\text { and location }\end{array}$ & $\begin{array}{l}\text { Length } \\
(\mathrm{km})\end{array}$ & $\begin{array}{l}\text { Off'set } \\
\text { (m) }\end{array}$ & $\begin{array}{c}\text { Number of events, } \\
\text { age of movement }\end{array}$ \\
\hline All segments------ & 35 & 6 & $\begin{array}{l}5-6 \text { events, } 3-33 \\
\text { ka ago. }\end{array}$ \\
\hline$A$, at trench 1---- & 5 & 3 & 1 event, $5 \mathrm{ka} \mathrm{ago}$ \\
\hline B, at trench $2^{----}$ & 8 & 4 & $\begin{array}{l}1 \text { event, } 15 \pm 3 \mathrm{ka} \\
\text { ago. }\end{array}$ \\
\hline$C$, no trench------ & 6 & 5.5 & 1 event, $5 \mathrm{ka} \mathrm{ago.}$ \\
\hline$D$, at trench $3---$ & 3 & 6 & $\begin{array}{l}1 \text { event, } 33 \mathrm{ka} \text { ago } \\
(+7 \mathrm{ka},-5 \mathrm{ka}) .\end{array}$ \\
\hline$E$, at trench 4---- & 7 & 4 & $\begin{array}{l}2 \text { events; less than } \\
3 \mathrm{ka} \text { ago and } \\
\text { about } 3 \mathrm{ka} \text { ago. }\end{array}$ \\
\hline $\begin{array}{l}\text { D, at trench } 3 ; \mathrm{E} \text {, } \\
\text { at trench } 4 ; \text { and } \\
\mathrm{F} \text {, no trench. }\end{array}$ & 15 & $1-2$ & $\begin{array}{l}1 \text { event, about } 150 \\
\text { ka ago. }\end{array}$ \\
\hline
\end{tabular}

The most recent movement on segment $D$ (pl. 2) occurred about $33 \mathrm{ka}$ ago, an estimate that is based on contents of both clay and calcium carbonate and on their estimated influx rates. Sediments within the upper fault block contain multiple buried paleosols that may have slowed initial degradation of the scarp. These scarps are more degraded than the 15-ka-old scarps of the Bonneville shoreline and segment B. Here too, scarp-degradation rates during intervals of the latest Pleistocene must have been about one-third of the Holocene rate.

Scarps of the La Jencia fault are everywhere fairly low, no more than $7 \mathrm{~m}$ high and commonly less than $5 \mathrm{~m}$. Although such high scarps need not have been produced by more than one fault movement, some may, in fact, reflect multiple movements, especially where segments connect or if they overlap. Scarps produced by multiple movements probably would not have profiles with compound slope angles unless a significant length of time separated the movements, such as occurred along segment $D$ (at trench 3 ).

In view of the calculated scarp-degradation rates, it seems reasonable that the time intervals between fault movements and the recency of the last fault movement determine whether or not a compound fault scarp is formed and preserved. For example, equal-size scarps formed by two movements $25 \mathrm{ka}$ ago and $30 \mathrm{ka}$ ago along a single segment would likely now have a smooth and rounded profile, whereas two movements 5 ka ago and $10 \mathrm{ka}$ ago may have produced a distinctly compound scarp.

Evidence of still-earlier movement on the La Jencia fault is present along segments $\mathrm{D}$ (at trench 3 ), $\mathrm{E}$ (at trench 4), and $F$ (at the north end, pl. 2). At trenches 3 and 4 , the earliest recorded faulting occurred about 150 ka ago. Applying Nash's (1980) scarp-degradation 
model and the average degradation rates observed on the La Jencia scarps, the 150-ka-old scarps are old enough to have been nearly obliterated prior to the most recent episode of faulting. At trench 3, the 150-ka-old fault scarp has been eroded to a slope of only several degrees; the younger faulting completely dominates the scarp profile. Scarps 1-2 $\mathrm{m}$ high along segment $F$ are barely discernible and have maximum-slope angles only $2^{\circ}-4^{\circ}$ more than the surface slope. Movement $150 \mathrm{ka}$ ago along the northern part of the fault (segments $D$, $\mathrm{E}$, and F; pl. 2) may have formed a single continuous rupture as much as $2 \mathrm{~m}$ in displacement or a series of ruptures that were closely spaced in time during a faulting episode analogous to the one in the late Quaternary ( $3 \mathrm{ka}$ ago to $33 \mathrm{ka}$ ago).

The La Jencia fault is marked by a prominent but low scarp that is a composite product of surface ruptures along discrete segments of the fault. Recent rupturing of the land surface occurred from about $33 \mathrm{ka}$ ago to less than $3 \mathrm{ka}$ ago, an interval of about 30,000 years (table 22). A minimum of five discrete fault movements (less than $3,3,5,15$, and $33 \mathrm{ka}$ ago) are required from the geologic evidence, and the average recurrence interval is about 7,500 years. As many as six movements are required if movement along segments $\mathrm{A}$ and $\mathrm{C}$ of the fault was not synchronous; the average recurrence interval would then be about 6,000 years.

Along the southern half of the La Jencia fault (segments A, B, and C; pl. 2) surficial deposits of widely varying ages are offset similar amounts. At trench 2 , alluvial-fan deposits at least $500 \mathrm{ka}$ old were offset for the first time about $15 \mathrm{ka}$ ago. Deposits of similar age preserved along the southern half of the fault indicate at least 0.5 million years of tectonic stability along the western front of the Magdalena Mountains.

A major contrast exists between slip rates along the La Jencia fault (about $100 \mathrm{~m} / \mathrm{Ma}$ ) during late Tertiary uplift of the Magdalenas and the relatively low slip rates (less than $10 \mathrm{~m} / \mathrm{Ma}$ ) during the middle and late Quaternary. Of equal contrast, but on a smaller scale, is the episodic activity in latest Pleistocene and Holocene time that punctuated a relatively long period of tectonic quiescence. These two types of activity may be fairly characteristic of some major range-bounding faults of the Rio Grande rift. In many places in the rift, the precipitous fronts of mountain ranges (the Sangre de Cristo, Sandia, Manzano, Lemitar, and Socorro Mountains, to mention a few) have more than $1,000 \mathrm{~m}$ of topographic relief but lack large fault scarps, faceted spurs, undissected linear margins, or other features that would reflect major Quaternary uplift. However, short remnants of degraded fault scarps along many of these same ranges indicate that uplift has not ceased but is more likely occurring at greatly reduced rates, on individual segments of long faults and in more widely separated intervals than during some parts of the late Cenozoic.

\section{SEISMICITY OF THE REGION}

Considering the abundance and wide distribution of Quaternary faults in this part of the Rio Grande rift (Machette and Colman, 1983), the area has surprisingly had no major earthquakes (Richter magnitude 6 or larger) in historic times (Sanford and others, 1972; Sanford, Olsen, and Jaksha, 1979, 1981). However, if the faults in the area have a composite-recurrence interval of many hundreds or more years, the area's historic record (about 115 years) may simply be too short to have included any major earthquakes.

Sanford and others (1972) predicted that the largest earthquake that might occur in the Socorro area in a 100 -year period would be of magnitude 6 . Indeed, the largest historic earthquakes in the Socorro region, and in New Mexico as a whole, occurred during a swarm in 1906 (Sanford and others, 1972). These earthquakes had an estimated intensity of VIII (modified Mercalli scale, roughly equivalent to magnitude 6; Sanford and others, 1981, tables 1 and 2) and caused moderate damage in the Socorro area. However, there is evidence that the swarm was caused by injection of magma into the crust (Sanford and others, 1981, p. 8); if so, these earthquakes were probably not associated with ground ruptures. During this study I found no ground ruptures along the La Jencia fault that formed in 1906 or in historic times.

During 1962 to 1977 , the two largest earthquakes in New Mexico had Richter local magnitudes $\left(M_{1}\right)$ of 4.1 and 4.3, and both had epicenters in the Colorado Plateaus Province of northwestern New Mexico. Earthquakes with epicenters in the Rio Grande rift were less than $M_{1}=4$. Thus, the distribution of large (felt) earthquakes seems anomalous with respect to the geologic record of abundant late Pleistocene and Holocene faulting (Machette and Colman, 1983).

In order to assess the hazards of earthquakes in this part of the Rio Grande rift, the nature of the rangebounding Quaternary faults should be considered, especially if these faults are the most likely to be active in the future. One interpretation is that these faults are basement-related structures that intersect competent rocks at depth and thus are capable of generating earthquakes of large magnitude. An opposing interpretation is that many of these faults are listric (flattening with depth) and are rooted in relatively incompetent rocks, as suggested by recent interpretations of Consortium for Continental Reflection Profiling (COCORP) seismic-reflection data (Cape and others, 
QUATERNARY MOVEMENT ALONG THE LA JENCIA FAULT, CENTRAL NEW MEXICO

1983, fig. 8). Faults of the latter type may be capable of producing only small-magnitude earthquakes (Anderson and others, 1983). Nevertheless, this investigation has shown that movement on the La Jencia fault is not a product of slow growth due to creep or withdrawal of ground water. Trenches across the La Jencia fault exposed scarp-derived colluvium that contains many large, coherent, jumbled blocks of soil derived from collapse of the free face of the fault; thus, the scarps were produced by catastrophic movement.

\section{PALEOSEISMICITY OF THE LA JENCIA FAULT}

Paleoseismology is the study of prehistoric earthquakes. These earthquakes may leave evidence in the form of ground ruptures (commonly as fault scarps) and other features such as sand boils, rockfalls, and disturbed lake beds. Estimates of the magnitude of ancient earthquakes are based most commonly on a comparison of the height and length of prehistoric fault scarps to that of historic fault scarps (Bonilla and Buchanan, 1970; Mark and Bonilla, 1977; Slemmons, 1977; and Wyss, 1979). In this study, I used four magnitude relations for normal-slip faults (Slemmons, 1977, line A of figs. 25, 27, 28, and 29, and fault-type $A$ of tables 11, 13,14 , and 15) to estimate the possible Richter magnitudes of late Quaternary earthquakes associated with the La Jencia fault:

1. Surface offset (also called displacement, D; fig. 11 and table on pl. 2);

2. Length of surface rupture $(\mathrm{L})$ along main fault;

3. Length times displacement $(\mathrm{L} \times \mathrm{D})$;

4. Length times the square of displacement $\left(L \times D^{2}\right)$.

Scarps of the La Jencia fault were formed by five or six discrete and separate fault movements associated with major earthquakes. Therefore, comparisons of the total length of the La Jencia fault (table 23, case 3, 35 $\mathrm{km}$ ) with the length of historic faults would yield earthquake magnitudes greater than that of any prehistoric earthquake on the La Jencia fault. Because data from individual fault segments would yield more reasonable estimates of earthquake magnitudes, two such cases are discussed here (table 23, cases 1 and 2).

The first (case 1) of three hypothetical cases for estimating paleoseismicity presented on table 23 is based on combinations of length of rupture and surface offset for the La Jencia fault. Case 1 is modeled after segment $B$, which has a moderate length of $8 \mathrm{~km}$ and an average surface offset of about $3 \mathrm{~m}$ (scarps are 2-4 m high). For comparison, case 2 is modeled after segment C, which is shorter $(6 \mathrm{~km})$ but has a larger amount of offset, typically $5 \mathrm{~m}$ (scarps are 3-6 $\mathrm{m}$ high). Case 3 is an extreme example that considers the fault's entire length of rupture $(35 \mathrm{~km})$ and an average of $4 \mathrm{~m}$ of offset.

Magnitudes computed from the four relationships of Slemmons (1977) differ by one full magnitude unit or more. For a given case, the maximum difference in the computed magnitude values is between the relations of surface offset and the relations of length; for example, in cases 1 and 2 the displacement-computed magnitudes are 7.4 and 7.3 (respectively), but the length-computed magnitudes are 6.3 and 6.1 (respectively). For faults that are segmented, length may be underestimated if the ends of faults have small scarps that were destroyed quickly, or if movement occurs on segments that partly overlap. Conversely, estimates of offset are often too large because the effects of local ground settlement or compound (multiple) faulting may not be recognized. However, these potential, opposing errors may reduce the overall error in magnitude computations. Relations 3 and 4 (table 23), which combine length and offset ( $L \times D$ and $L \times D^{2}$, respectively), yield values that cluster around Richter magnitude 7.0 (cases 1 and 2, table 23) and around Richter magnitude 7.3 (case 3).

Because the La Jencia fault is segmented and because the geologic evidence presented here shows that fault segments have moved independently of one another, the 7.3 value probably exceeds the maximum credible earthquake that occurred on the La Jencia fault during the late Quaternary. Thus, the best estimate of Richter magnitude for prehistoric earthquakes on the La Jencia fault is about 7.0, based on amount of offset and length of rupture. This value lies between the $M=7.3$ Borah Peak, Idaho, earthquake of October 28, 1983 (Crone and Machette, 1984), and the $M=6.8$ Dixie Valley, Nevada, earthquake of December 16, 1954 (Slemmons, 1977, table 16), two prominent historic earthquakes on large range-bounding faults in the interior of the United States.

The seismic moment that might have been generated during formation of surface ruptures along the La Jencia fault (relation 5, table 23) can also be estimated using these same fault parameters. Seismic moment $(M o)$ and the inferred moment magnitude $(M)$ are used here because they are more meaningful in an engineering sense than Richter magnitudes (local, surface, and body wave), which tend to be nonlinear estimates of force in large earthquakes (see discussion of Hanks and Kanamori, 1979). Seismic moment is the product of the shear modulus (also known as the modulus of rigidity), the area of slippage on the fault plane, and the average amount of offset (relation 5, table 23). To calculate seismic moment, I used an average depth of $12 \mathrm{~km}$, and following Brune (1968), a shear modulus of $3.3 \times 10^{11}$ dynes $/ \mathrm{cm}^{2}$. (Depth is considered here as the downdip 
TABLE 23.-Calculated magnitudes of prehistoric earthquakes along the La Jencia fault

\begin{tabular}{|c|c|c|c|}
\hline Magnitude relations and regression equations & $\begin{array}{c}\text { Case } \\
1 \\
L=8 \\
D=3\end{array}$ & $\begin{array}{l}\text { Case } \\
2 \\
L=5 \\
D=6\end{array}$ & $\begin{array}{c}\text { Case } \\
3 \\
L=35 \\
D=6\end{array}$ \\
\hline $\begin{array}{l}\text { 1. Magnitude versus maximum surface displacement } \\
M=6.8+1.05(\log D) \text {. }\end{array}$ & 7.3 & 7.4 & 7.6 \\
\hline $\begin{array}{l}\text { 2. Magnitude versus length of surface rupture } \\
\qquad M=1.85+1.15(\log L) \text {. }\end{array}$ & 6.1 & 6.3 & 7.1 \\
\hline $\begin{array}{l}\text { 3. Magnitude versus length times displacement } \\
M=4.55+0.53(\log L D) \text {. }\end{array}$ & $6.8 *$ & $6.9^{*}$ & 7.4 \\
\hline $\begin{array}{l}\text { 4. Magnitude versus length times displacement squared } \\
\qquad M=5.57+0.30\left(\log L D^{2}\right) \text {. }\end{array}$ & $7.2^{*}$ & $7.1^{*}$ & 7.2 \\
\hline \multirow[t]{2}{*}{$\begin{array}{l}\text { 5. Moment magnitude versus seismic moment } \\
\begin{array}{l}M o=\angle A D(W=12) \\
\boldsymbol{M}=2 / 3(\log M 0)-10.7\end{array}\end{array}$} & $\begin{array}{l}9.5 \\
6.6^{*}\end{array}$ & $\begin{array}{l}9.9 \\
6.7^{*}\end{array}$ & $\begin{array}{r}55.0 \\
7.0\end{array}$ \\
\hline & $\begin{array}{l}\text { Case } \\
\qquad \\
L=35 \\
W=12\end{array}$ & $\begin{array}{l}\text { Case } \\
5 \\
L=65 \\
W=12\end{array}$ & \\
\hline $\begin{array}{l}\text { 6. Source-rupture area versus magnitude } \\
M=4.15+\log \mathrm{A} \text {. }\end{array}$ & $6.8^{*}$ & 7.0 & \\
\hline
\end{tabular}

*Magnitude values that seem most reasonable based on geologic evidence.

distance to the focal center of an earthquake.) The calculated seismic moments range from $9.5 \times 10^{25}$ to $55 \times 10^{25}$ dyne-cm for the three cases outlined previously (table 23). These seismic moments relate to moment magnitudes $(M)$ of $6.6,6.7$, and 7.0 (relation 5 , table 23) according to Hanks and Kanamori's (1979) empirical relation.

The first four relations of prehistoric earthquake magnitude rely on two basic fault parameters, length and offset. Wyss (1979) suggested that the maximum magnitudes of earthquakes should, more logically, be related to the area of rupture source (relation 6, table 23 ), that is, the area of the fault plane that moved. $\mathrm{He}$ argued that such magnitude estimates are more accurate than those based on rupture length because earthquakes on narrow faults are less powerful than earthquakes on wide faults (Wyss uses the terms narrow (shallow) and wide (deep) in a vertical sense). Rupture-source area is the product of maximum source length and width; source length is the horizontal distance along the seismically active fault plane, and width is the downdip distance from the surface to the focal center of the earthquake. Wyss (1979) justified using source length rather than rupture length because the source length of modern earthquakes (as indicated by the zone of aftershock activity) may exceed the length of rupture by a factor of 5-45 (Wyss, 1979, table 1).

Scarps along the La Jencia fault resulted from episodic movement on each of six discrete fault segments. Thus, it could be said that a total-composite length of $35 \mathrm{~km}$ for all segments should be the source length (relation 6, case 4, table 23). However, the Bear and Magdalena Mountains form a block nearly $65 \mathrm{~km}$ long; this length is surely equal to (and probably greater than) the maximum source length (case 5). Because the La Jencia fault is not now seismically active, its source area cannot be determined directly. I choose a width of $12 \mathrm{~km}$, midway in Wyss's suggested range of 5-20 km for normal-slip faults. The calculated maximum source area for the La Jencia fault is $420-780 \mathrm{~km}^{2}$, although the most reasonable value is probably close to $420 \mathrm{~km}^{2}$. The magnitudes estimated from Wyss's relation are between 6.8 and 7.0.

To summarize, the calculations from the preferred relations yield fairly consistent estimates of magnitude for late Quaternary earthquakes that formed ruptures along the La Jencia fault. These earthquakes probably 
had moment magnitudes of about 6.6 to as much as 7.0 and had Richter magnitudes of 6.9-7.2 (based on length of rupture and amount of surface offset) or about 6.8 (based on area of source rupture).

\section{IMPLICATIONS FOR SEISMICITY IN THE RIO GRANDE RIFT}

Earthquakes as strong as Richter magnitude 7 produced ground ruptures along the La Jencia fault five or six times during the late Quaternary, between less than $3 \mathrm{ka}$ and $33 \mathrm{ka}$ ago, an interval of about 30,000 years. The average recurrence interval for these earthquakes is between 6,000 and 7,500 years. However, much of the faulting apparently occurred in the middle to late Holocene (the Holocene recurrence interval is between 2,000 years and 2,500 years). Although large $(M>6)$ earthquakes related to faulting have not been felt in the Rio Grande rift in historic time, the abundance of faults having Quaternary movement suggests that such earthquakes have been common during the Quaternary. If many of the faults along the Rio Grande rift have histories of recent offset and relatively short recurrence intervals, as does the La Jencia fault, then the rift may have a significant potential for earthquake hazards that is not reflected in the modern record of seismicity.

The history of faulting that has emerged from this study may be characteristic of many range-bounding faults of the Rio Grande rift. The pattern of segmentation and recurrence along the La Jencia fault previously had not been recognized for faults in the rift, and this pattern of segmented prehistoric movement had not been widely documented for other faults in the United States until recently (see discussion of segmentation and seismic gaps by Wallace and Whitney, 1983; Wallace, 1984). Thus, the history of offset along the La Jencia fault has significant implications for assessing the past and future seismicity in the Rio Grande rift and other areas of extensional tectonism.

Many questions remain unanswered regarding both the rift's past tectonic history and its potential for future seismicity. Probably the most fundamental question is whether these faults are capable of producing large-magnitude earthquakes $(M>6)$ or whether they might be listric faults seated in relatively shallow rocks and produce only small- to moderate-magnitude earthquakes $(M<6)$, as has occurred historically.

It seems apparent that during the Cenozoic there have been dramatic changes in the rate of faulting associated with the uplift of mountain blocks in and along the Rio Grande rift. Should range-bounding faults along precipitous mountain fronts that lack young scarps be considered as posing no future seismic hazard, or are they like the La Jencia fault was 50 ka ago? If so, perhaps they should be considered potentially hazardous faults. Should the relative lack of modern seismicity and lack of recent offset on some Quaternary faults in the rift be considered typical, or will these faults have new pulses of activity? And should the La Jencia fault, a newly reactivated structure, be considered less of a hazard because of its recent movement? Has it released all of its accumulated strain as some evidence suggests, or is this recent episode of activity merely part of an ongoing, longer phase of tectonism? These unanswered questions are fundamental to understanding and assessing the seismic hazards associated with the Rio Grande rift.

\section{REFERENCES CITED}

Anderson, R. E., Zoback, M. L., and Thompson, G. A., 1983, Implications of selected subsurface data on the structural form and evolution of some basins in the northern Basin and Range Province, Nevada and Utah: Geological Society of America Bulletin, v. 84, no. 12 , p. $1055-1072$.

Antevs, Ernst, 1955, Geologic-climatic dating in the West: American Antiquity, v. 20, no. 4, pt. 1, p. 317-335.

Bachman, G. O., and Machette, M. N., 1977, Calcic soils and calcretes of the southwestern United States: U.S. Geological Survey OpenFile Report 77-794, 163 p.

Barker, J. M., 1983, Preliminary investigation of the origin of the Riley travertine, Socorro County, New Mexica, in Chapin, C. E., ed., Guidebook of the Socorro Country II: New Mexico Geological Society, 34th Field Conference, p. 269-276.

Birkeland, P. W., 1974, Pedology, weathering, and geomorphological research: New York, Oxford University Press, 285 p.

Bonilla, M. G., and Buchanan, J. M., 1970, Interim report on worldwide historic surface faulting: U.S. Geological Survey open-file report, $32 \mathrm{p}$.

Brown, D. M., 1972, Geology of the southern Bear Mountains, Socorro County, New Mexico: New Mexico Bureau of Mines and Mineral Resources Open-File Report 42, 110 p., 1 pl., map scale 1:24,000.

Brune, J. N., 1968, Seismic moment, seismicity, and rate of slip along major fault zones: Journal of Geophysical Research, v. 73, p. 777-780.

Bucknam, R. C., and Anderson, R. E., 1979, Estimation of fault-scarp ages from a scarp height-slope angle relationship: Geology, v. 7, no. 1, p. 11-14.

Cape, C. D., McGeary, Susan, and Thompson, G. A., 1983, Cenozoic normal faulting and shallow structure of the Rio Grande rift near Socorro, New Mexico: Geological Society of America Bulletin, v. 94, no. 1 , p. 3-14.

Chamberlin, R. M., 1980, Cenozoic stratigraphy and structure of the Socorro Peak volcanic field, central New Mexico: New Mexico Bureau of Mines and Mineral Resources Open-File Report 118, 532 p., 3 pl., map scale 1:12,000.

1982, Geologic map, cross sections, and map units of the Lemitar Mountains, Socorro County, New Mexico: New Mexico Bureau of Mines and Mineral Resources Open-File Report 169, 3 pl, map scale $1: 12,000$.

1983, Cenozoic domino-style crustal extension in the Lemitar Mountains, New Mexico-A summary, in Chapin, C. E., ed., Guidebook of the Socorro Country II: New Mexico Geological Society, 34th Field Conference, p. 111-118. 
Chamberlin, R. M., Osburn, G. R., Chapin, C. E., Machette, M. N., Barker, J. M., Hawley, J. W., Cather, S. M., Osburn, J. C., and Anderson, O. J., 1983, Second day road $\log$ from Socorro to Lemitar Mountains, La Jencia basin, Baca Canyon, Riley, Jeter mine, and San Lorenzo Canyon [New Mexico], in Chapin, C. E., ed., Guidebook of the Socorro Country II: New Mexico Geological Society, 34th Field Conference, p. 29-59.

Chapin, C. E., Chamberlin, R. M., Osburn, G. R., White, D. W., and Sanford, A. R., 1978, Exploration framework of the Socorro geothermal area, New Mexico, in Chapin, C. E., and Elston, W. E., eds., Field guide to selected cauldrons and mining districts of the Datil-Mogollon volcanic field, New Mexico: New Mexico Geological Society Special Publication 7, p. 115-129.

Chapin, C. E., Jahns, R. H., Chamberlin, R. M., and Osburn, G. R., 1978, First day road log from Socorro to Truth or Consequences via Magdalena and Winston [New Mexico], in Chapin, C. E., and Elston, W. E., eds., Field guide to selected cauldrons and mining districts of the Datil-Mogollon volcanic field, New Mexico: New Mexico Geological Society Special Publication 7, p. 1-31.

Chapin, C. E., and Seager, W. R., 1975, Evolution of the Rio Grande rift in the Socorro and Las Cruces areas [New Mexico], in Seager, W. R., Clemons, R. E., and Callender, J. F., eds., Guidebook of the Las Cruces country: New Mexico Geological Society, 26th Field Conference, p. 297-321.

Crone, A. J., 1983, Amount of displacement and estimated age of a Holocene surface faulting event, eastern Great Basin, Millard County, Utah, in Gurgel, K. D., ed., Geologic excursions in neotectonics and engineering geology in Utah: Utah Geological and Mineralogical Survey Special Studies 62, p. 49-55.

Crone, A. J., and Machette, M. N., 1984, Surface faulting accompanying the Borah Peak earthquake, central Idaho: Geology, v. 12, no. 11, p. 664-667.

Denny, C. S., 1940, Tertiary geology of the San Acacia area, New Mexico: Journal of Geology, v. 48, no. 1, p. 73-106.

1941, Quaternary geology of the San Acacia area, New Mexico: Journal of Geology, v. 49, no. 3, p. 225-260.

Dodge, R. L., and Grose, L. T., 1979, Seismotectonic and geomorphic evolution of a typical basin and range normal fault, the Holocene Black Rock fault, northwestern Nevada [abs.]: Geological Society of America Abstracts with Program, v. 11, no. 3, p. 75.

1980. Tectonic and geomorphic evolution of the Black Rock fault, northwestern Nevada, in Andrise, P. C., compiler, Earthquake hazards along the Wasatch and Sierra Nevada frontal fault zones: U.S. Geological Survey Open-File Report 80-801, p. 494-508.

Gilbert, G. K., 1890, Lake Bonneville: U.S. Geological Survey Monograph 1, 438 p.

Gile, L. H., 1975, Holocene soils and soil-geomorphic relations in an arid region of southern New Mexico: Quaternary Research, v. 5, no. 3 , p. $321-360$.

1977, Holocene soils and soil-geomorphic relations in a semiarid region of southern New Mexico: Quaternary Research, v. 7, no. 1 , p. 112-132.

Gile, L. H., and Grossman, R. B., 1979, The Desert Project soil monograph: U.S. Department of Agriculture, Soil Conservation Service, $984 \mathrm{p}$.

Gile, L. H., and Hawley, J. W., 1966, Periodic sedimentation and soil formation on an alluvial-fan piedmont in southern New Mexico: Soil Science Society of America Proceedings, v. 30, no. 2, p. 261-268.

Gile, L. H., Hawley, J. W., and Grossman, R. B., 1981, Soils and geomorphology in the Basin and Range area of southern New Mexico-Guidebook to the Desert Project: New Mexico Bureau of Mines and Mineral Resource Memoir 39, 222 p.
Gile, L. H., Peterson, F. F., and Grossman, R. B., 1965, The Khorizon-A master soil horizon of carbonate accumulation: Soil Science, v. 99 , no. 5, p. 74-82.

1966, Morphology and genetic sequences of carbonate accumulation in desert soils: Soil Science, v. 101, no. 5, p. 347-360.

Hanks, T. C., and Kanamori, Hiroo, 1979, A moment magnitude scale, in Hanks, T. C., and Kanamori, Hiroo, eds., Fault mechanics: Journal of Geophysical Research, v. 84, no. B5, p. 2348-2350.

Hawley, J. W., 1975, The Desert Soil-Geomorphology project, in Seager, W. R., Clemons, R. E., and Callender, J. F., eds., Guidebook of the Las Cruces country: New Mexico Geological Society, 26th Field Conference, p. 183-186.

compiler, 1978, Guidebook to the Rio Grande rift in New Mexico and Colorado: New Mexico Bureau of Mines and Mineral Resources Circular 163, 241 p.

Haynes, C. V., Jr., 1968, Geochronology of late Quaternary alluvium, in Morrison, R. B., and Wright, H. E., Jr., eds., Means of correlation of Quaternary successions: International Association for Quaternary Research, 7th Congress, 1965, Proceedings, v. 8, p. 591-631.

Izett, G. A., and Wilcox, R. E., 1982, Map showing localities and inferred distribution of the Huckleberry Ridge, Mesa Falls, and Lava Creek ash beds (Pearlette family ash beds) of Pliocene and Pleistocene age in the western United States and southern Canada: U.S. Geological Survey Miscellaneous Investigations Series Map I-1325, map scale 1:4,000,000.

Loughlin, G. F., and Koschmann, A. H., 1942, Geology and ore deposits of the Magdalena district, New Mexico: U.S. Geological Survey Professional Paper 200, 168 p.

Machette, M. N., 1978a, Geologic map of the San Acacia quadrangle, Socorro County, New Mexico: U.S. Geological Survey Geologic Quadrangle Map GQ-1415, map scale 1:24,000.

compiler, $1978 \mathrm{~b}$, Preliminary geologic map of the Socorro $1^{\circ}$ by $2^{\circ}$ quadrangle, central New Mexico: U.S. Geological Survey Open-File Report 78-607, map scale 1:250,000.

$1978 c$, Dating Quaternary faults in the southwestern United States by using buried calcic paleosols: U.S. Geological Survey Journal of Research, v. 6, no. 3, p. 369-381.

1982, Quaternary and Pliocene faults in the La Jencia and southern part of the Albuquerque-Belen basins, New MexicoEvidence of fault history from scarp morpholology and Quaternary geology, in Grambling, J. A., and Wells, S. G., eds., Guidebook of the Albuquerque Country II: New Mexico Geological Society, 33rd Field Conference, p. 161-169.

1985, Calcic soils of the southwestern United States, in Weide, D. L., ed., Soils and Quaternary geology of the southwestern United States: Geological Society of America Special Paper 203, p. 1-21.

Machette, M. N., Birkeland, P. W., Burke, R. M., Guccione, M. J., Kihl, Rolf, and Markos, Gergely, 1976, Field descriptions and laboratory data for a Quaternary soil sequence in the GoldenBoulder portion of the Colorado Piedmont: U.S. Geological Survey Open-File Report 76-804, $20 \mathrm{p}$.

Machette, M. N., Birkeland, P. W., Markos, Gergely, and Guccione, M. J., 1976, Soil development in Quaternary deposits in the Golden-Boulder portion of the Colorado Piedmont, in Epis, R. C., and Weimer, R. J., eds., Studies in Colorado field geology: Colorado School of Mines Professional Contributions 8, p. 339-357.

Machette, M. N., and Colman, S. M., 1983, Age and distribution of Quaternary faults in the Rio Grande rift-Evidence from morphometric analysis of fault scarps: Geological Society of America Abstracts with Program, v. 15, no. 5, p. 320. 
Machette, M. N., and McGimsey, R. G., 1983, Map of Quaternary and Pliocene faults in the Socorro and western part of the Fort Sumner $1^{\circ}$ by $2^{\circ}$ quadrangles, New Mexico: U.S. Geological Survey Miscellaneous Field Studies Map MF-1465-A, map scale 1:250,000.

Mark, R. K., and Bonilla, M. G., 1977, Regression analysis of earthquake magnitude versus fault length in estimating maximum expectable earthquakes: Geology, v. 5, no. 8, p. 464-466.

Markgraf, Vera, Bradbury, J. P., Forester, R. M., Singh, G., and Sternberg, R. S., 1984, San Agustin Plains, New Mexico-Age and paleoenvironmental potential reassessed: Quaternary Research, v. 22 , no. 3 , p. $336-343$.

Mehringer, P. J., 1967, Pollen analysis and the alluvial chronology: The Kiva, Journal of the Arizona Archeological and Historical Society, v. 32 , p. $96-101$.

Naeser, C. W., Izett, G. A., and Wilcox, R. E., 1973, Zircon fission-track ages of Pearlette family ash beds in Meade County, Kansas: Geology, v. 1, no. 4, p. 187-189.

Nash, D. B., 1977, The evolution of abandoned wave-cut bluffs in Emmet County, Michigan: Ann Arbor, University of Michigan Ph.D. disseration, $255 \mathrm{p}$.

1980, Morphologic dating of degraded normal-fault scarps: Journal of Geology, v. 88, no. 3, p. 353-360.

Osburn, G. R., 1978, Geology of the eastern Magdalena Mountains, Water Canyon to Pound Ranch, Socorro County, New Mexico: New Mexico Bureau of Mines and Mineral Resources Open-File Report 113,160 p., 1 pl., map scale 1:24,000.

Pierce, K. L., 1979, History and dynamics of glaciation in the northern Yellowstone National Park area: U.S. Geological Survey Professional Paper 729-F, p. F1-F90.

1985, Quaternary history of faulting on the Arco segment of the Lost River. Fault, central Idaho, in Stein, R. S., and Bucknam, R. C., eds., Proceedings of Workshop XXVIII, On the Borah Peak, Idaho, Earthquake: U.S. Geological Survey Open-File Report 85-290, p. 195-206.

Sanford, A. R., 1968, Gravity survey in central Socorro County, New Mexico: New Mexico Bureau of Mines and Mineral Resources Circular $91,14 \mathrm{p}$.

Sanford, A. R., Budding, A. J., Hoffman, J. P., Alptekin, O. S., Rush, C. A., and Toppozada, T. R., 1972, Seismicity of the Rio Grande rift in New Mexico: New Mexico Bureau of Mines and Mineral Resources Circular 120, $19 \mathrm{p}$.

Sanford, A. R., Olsen, K. H., and Jaksha, L. H., 1979, Seismicity of the Rio Grande rift, in Riecker, R. L, ed, Rio Grande rift-Tectonics and magmatism: Washington, D.C., American Geophysical Union, p. $145-168$.

1981, Earthquakes in New Mexico, 1849-1977: New Mexico Bureau of Mines and Mineral Resources Circular 171, 20 p.

Scott, G. R., 1963, Quaternary geology and geomorphic history of the Kassler quadrangle, Colorado: U.S. Geological Survey Professional Paper 421-A, p. 1-70.

Scott, W. E., McCoy, W. D., Shroba, R. R., and Rubin, Meyer, 1983, Reinterpretation of the exposed record of the last two cycles of Lake Bonneville, Western United States: Quaternary Research, v. 20, no. 3, p. 261-265.

Sieh, K. E., 1978, Prehistoric large earthquakes produced by slip on the San Andreas fault at Pallett Creek, California: Journal of Geophysical Research, v. 83, no. B8, p. 3907-3939.

Slemmons, D. B., 1977, Faults and earthquake magnitude, in Stateof-the-art for assessing earthquake hazards in the United States: U.S. Army Corps of Engineers, Waterways Experiment Station, Miscellaneous Paper S-73-1, Report 6, p. 1-129.

Sumner, Ward, 1980, Geology of the Water Canyon-Jordan Canyon areas, Socorro County, New Mexico: New Mexico Bureau of Mines and Mineral Resources Open-File Report 135, 152 p., 1 pl., map scale $1: 12,000$.
Swan, F. H., III, Schwartz, D. P., and Cluff, L. S., 1980, Recurrence of moderate to large magnitude earthquakes produced by surface faulting on the Wasatch fault zone, Utah: Seismological Society of America Bulletin, v. 70, no. 5, p. 1431-1462.

U.S. Department of Agriculture, Soil Conservation Service, 1975, Soil taxonomy-A basic system of soil classification for making and interpreting soil surveys: U.S. Department of Agriculture Handbook 136, $754 \mathrm{p}$.

U.S. National Oceanic and Atmospheric Administration, 1978, Climate of the States, v. 2: Detroit, Mich., Gale Research Ca, 1185 p.

U.S. Weather Bureau, 1965, Climatology of the United States no. 86-25 [New Mexico]-Climatic summary of the United States, Supplement for 1951 through 1960: U.S. Department of Commerce, p. 20,61 .

Walker, T. R., Waugh, Brian, and Crone, A. J., 1978, Diagenesis of first cycle desert alluvium of Cenozoic age, southwestern United States and northwestern Mexico: Geological Society of America Bulletin, v. 89 , no. 1 , p. $19-32$.

Wallace, R. E., 1977, Profiles and ages of young fault scarps, northcentral Nevada: Geological Society of America Bulletin, v. 88, no. 9, p. 1267-1281.

1984, Patterns and timing of late Quaternary faulting in the Great Basin Province and relation to some regional tectonic features: Journal of Geophysical Research, v. 89, na B7, p. 5763-5769.

Wallace, R. E., and Whitney, R. A., 1983, Late Quaternary history of the Stillwater seismic gap [Nevada]: Bulletin of the Seismological Society of America, v. 74, no. 1, p. 301-314.

Weber, R. H., and Bassett, W. A., 1963, K-Ar ages of Tertiary volcanic and intrusive rocks in Socorro, Catron, and Grant Counties, New Mexico, in Kuellmer, F. J., ed., Guidebook of the Socorro region, New Mexico: New Mexico Geological Society, 14th Field Conference, p. 220-223.

Weber, R. H., and Stearns, C. E., 1965, Stop 11-41-San Agustin Plains, in Southwestern arid lands: International Association on Quaternary Research, 7th Congress, Field Conference H, Guidebook, p. 83-84.

Weber, R. H., and Willard, M. E., 1963, Road $\log$ C, Socorro westward to Catron County line via U.S. [Highway] 60, in Kuellmer, F. J., ed., Guidebook of the Socorro region, New Mexico: New Mexico Geological Society, 14th Field Conference, p. 20-25.

Woodward, L. A., Callender, J. F., Gries, L. J., Seager, W. R., Chapin, C. E., Zilinski, R. E., and Shaffer, W. L., compilers, 1975, Tectonic map of Rio Grande region from New Mexico-Colorado border to Presida, Texas, in Seager, W. R., Clemons, R. E., and Callender, J. F., eds., Guidebook of the Las Cruces country: New Mexico Geological Society, 26th Field Conference, p. 239, 1 pl., map scale 1:1,000,000.

Wyss, Max, 1979, Estimating maximum expectable magnitude of earthquakes from fault dimensions: Geology, v. 7, na. 7, p. 336-340.

\section{DESCRIPTION OF SOIL HORIZONS IN TRENCH 1}

\section{SOIL D (UPPER HOLOCENE)}

Very weakly developed soil formed on unit 1 , the younger of two colluvial deposits (units 1 and 2, pl. 1A). Soil profile consists of weak, organic-poor A horizon, and $B$ horizon characterized merely by development of ped 
structure (nonargillic B horizon). Deposition of colluvium and subsequent soil formation postdate last surface rupture of La Jencia fault near trench 1. Soil description (profile T1-1, upper part) and laboratory data are in table 4 . Thickness variable, $30-40 \mathrm{~cm}$.

$\mathrm{A}+\mathrm{B}$ horizons-Undifferentiated solum. Consists of 10 to 15 -m-thick, dark-brown to brown (10YR4/3d), noncalcareous, gravelly, sandy loam having very weak, fine platey to single-grain structure. $B$ horizon is slightly redder (9YR4.5/3d, brown), 20-cm-thick, noncalcareous, very gravelly, sandy loam having weak, fine subangular blocky structure. No evidence, such as clay films or secondary clay accumulation, warrants designation as argillic $B$ horizon. Total thickness of soil about $30-35 \mathrm{~cm}$. Where unit 1 is more than $35 \mathrm{~cm}$ thick, basal part has Cn horizon (mapped with the overlying A+B horizons, pl. 1A).

2Cn horizon-Unaltered unit 2 (pl. 1A).

\section{SOIL E (HOLOCENE)}

Consists of two lateral components, a relict soil and a much less developed buried soil, both formed on unit 3 (pl. 1A). Relict soil on upthrown fault block consists of $\mathrm{A}$ and weak $\mathrm{Bt}$ horizons. Buried component on downdropped fault block consists of single 20 - to $40-\mathrm{cm}$ thick, poorly developed Cca horizon and calcareous, weakly developed B horizon. Soil description (profile T1-2) and laboratory data for relict soil are in table 3. Soil description (profile T1-1, lower part) and laboratory data for buried soil are in table 4 .

$3 \mathrm{~A}+\mathrm{Bt}$ horizons-Upthrown fault block only. A horizon consists of dark-yellowish-brown to yellowish-brown (10YR4.5/5d) noncalcareous, very gravelly, sandy loam having very weak platey to single-grain structure. About 60 percent of surface mantled by 1 - to 3 -cm-diameter angular clasts that form desert pavement. A-horizon thickness $5-10 \mathrm{~cm}$. Bt horizon is argillic, brown to strong brown $(7.5 Y R 4.5 / 5 \mathrm{~d})$, and has very gravelly sandy loam to very gravelly loam texture and weak, fine subangular blocky structure. Bt horizon about $10 \mathrm{~cm}$ thick.

3Cca subhorizon-Subhorizon developed only on downdropped fault block, where buried. Slightly calcareous, pale-brown (10YR6/3d), very gravelly, sandy loam having single-grain structure. Calcium carbonate is weak stage I (Gile and others, 1966) and forms discontinuous coatings on clasts. Carbonate was leached from soil on upthrown block leaving $\mathrm{Cn}$ horizon (former Cca subhorizon) having very sparse but relatively thick coatings of carbonate in pits and hollows of clasts. Cca subhorizon also includes thin, slightly reddened, weakly calcareous B horizon, which may be partly pedogenic and partly depositional. Total horizon thickness about $30 \mathrm{~cm}$.

3Cn subhorizon-Unaltered unit 3, 20- to 35-cm-thick, light-brown (10YR6/3d), noncalcareous to slightly calcareous, very gravelly, loamy sand to very gravelly sand having single-grain structure.

3Cox subhorizon-Slightly oxidized (reddened) unit 3 ; oxidation may not be pedogenic. Thickness about $60-100 \mathrm{~cm}$.

3C1n subhorizon-Unaltered subunit of 3 . Subdivisions of the basal part of unit 3 are based on grain size and sorting, much like facies in rock units (for example, the 3C3 subhorizon may overlie the 3C2n subhorizon).

3C2n subhorizon-Unaltered subunit of 3.

3C3n subhorizon-Unaltered subunit of 3.

$$
\text { SOIL(?) } \mathrm{F}
$$

(LOWER HOLOCENE OR UPPER PLEISTOCENE)

Buried soil(?) in parent material (unit 4, pl. 1A) having slight oxidization that may or may not be due to pedogenic processes. Original bedding intact, and no soil structure developed in unit 4. Mapped as soil subhorizons for convenience only.

4C10x subhorizon-Slightly oxidized subunit of 4 .

4C2ox subhorizon-Slightly oxidized subunit of 4 .

4C3ox subhorizon-Slightly oxidized subunit of 4 .

\section{DESCRIPTION OF SOIL HORIZONS IN TRENCH 2}

\section{SOIL G (HOLOCENE AND UPPER PLEISTOCENE)}

Relict soil developed on scarp colluvium (units 1 and 2, pl. 1B). Consists of undifferentiated A and B horizons in unit 1 and underlying, laterally gradational B horizon in unit 2. Soil development postdates most recent 
movement of faults exposed in trench 2. Soil description (profile T2-32, upper part) and laboratory data are in table 7.

$\mathrm{A}+\mathrm{B}$ horizons-A horizon dark-brown (10YR4/3.5d), gravelly, sandy loam having weak, fine platey to single-grain structure. B horizon brown (7.5 YR4.5/4d), gravelly to very gravelly, sandy loam to loam having moderate, fine to medium subangular blocky structure. Basal part of B horizon has weak accumulation of stage I calcium carbonate.

2B horizon, and 2Bca and 2B2ca subhorizons-Brown (7.5YR5/4d) to reddish-yellow or strong-brown (7.5YR5.5/4d), very gravelly loam having moderate, medium subangular blocky structure. Grades downslope from noncalcareous $2 \mathrm{~B}$ horizon to $2 \mathrm{Bca}$ and 2B2ca subhorizons that have weak stage II calcium carbonate.

3Cn horizon-Unaltered unit 3 (pl. 1B).

4Cn horizon-Unaltered unit 4 (pl. 1B).
5B3t subhorizon-Includes basal part of 5Bt horizon in upper and lower ends of trench where it is locally subdivided from the 5B2t for sampling. Consists of yellowish-red (5YR5/8d), very gravelly, sandy loam with weak- to moderate-medium subangular blocky structure. Clay films less common and thinner than above.

5Cox horizon-Oxidized and slightly clay-enriched part of unit 5. Consists of strong-brown (7.5YR5/6d), very gravelly, loamy sand to very gravelly, sandy loam having single-grain structure (weak, medium subangular blocky structure in sand lenses). Oxidized yellowishred $(5 Y R 5 / 8 \mathrm{~d})$ clay films on clasts and also mechanically infiltrated clay laminae. Considered basal, pedogenic part of soil H. Stratigraphically lower horizons may be largely result of diagenetic alteration but were mapped as soil horizons.

6Cox horizon-Yellowish-red (5YR5/6d), oxidized, very gravelly, loamy sand having single-grain structure. Abundant clay films and laminae are red (2.5YR5/8d) and highly oxidized. Horizon makes up all of unit 6 (pl. 1B).

7Cox horizon-Yellowish-red (5YR5/6d), oxidized, very gravelly sand having single-grain structure. Clay films and laminae sparse.

7Cn horizon-Unaltered unit 7 (pl. 1B), brown (7.5YR5/4d), very gravelly sand having single-grain structure.

8Cox horizon-Slightly oxidized, brown (7.5YR5/4d), very gravelly sand having single-grain structure. Mapped within zone of faulting (10-19 $\mathrm{m}$ from trench headwall).

$8 \mathrm{Cn}$ horizon-Unaltered unit 8 (pl. 1B), brown (7.5YR5/3d) to yellowish-brown $(10 Y R 5 / 4 \mathrm{~d})$, very gravelly sand with single-grain structure. Mapped in upthrown fault block, east of $\mathbf{1 0 . 6} \mathrm{m}$ from headwall

sists of yellowish-red to strong-brown $(6.5 Y R 5 / 6 \mathrm{~d})$, very gravelly loam having weak, medium subangular blocky structure. On stable upthrown surface includes A horizon that is thin, brown (8YR4.5/4d), gravelly sandy loam.

5B2t subhorizon-Includes upper one-half of relict soil's Bt horizon and all of buried soil's Bt horizon. Consists of yellowish-red (5YR5/8d), very gravelly, sandy loam to gravelly, sandy clay (where best developed), having medium-moderate to strong-coarse subangular blocky structure. Clay films common and thick on clasts, common and moderate on ped faces.

\begin{abstract}
of trench.
of trench.
\end{abstract}

\section{DESCRIPTION OF SOIL HORIZONS IN TRENCH 3}

Cn horizon-Unaltered unit 1 (pl. 1C).

SOIL M (HOLOCENE AND UPPER PLEISTOCENE)

Relict soil developed on scarp colluvium (unit 2, pl. 1C). Consists of two generalized mapping units; contact between them is upper limit of pedogenic calcium 
carbonate. Soil development postdates most recent movement of faults exposed in trench 3. Soil description (profile T3-14, upper part) and laboratory data are in table 9.

$2 \mathrm{~A}+\mathrm{Bt}$ horizons-Consists of $\mathrm{A}$ horizon and leached part of underlying argillic B horizon. A horizon is slightly organic, dark-brown (10YR3/3m), sandy loam having moderate, medium subangular blocky structure. Bt horizon brown (9YR4.5/3d), sandy loam having moderate, medium subangular blocky structure. Bt horizon leached of calcium carbonate; depth of leaching increases from $15 \mathrm{~cm}$ near midpoint of fault scarp to $40-55 \mathrm{~cm}$ at toe of scarp.

2Bca subhorizon-Light-yellowish-brown (9YR6/4d) to brown (7.5YR5.5/4d), calcareous loam to sandy loam having moderate, medium subangular blocky structure. Includes thin Bt horizon on upper onehalf of scarp and transitional Bca and Cca subhorizons on lower part of scarp. Calcium carbonate in veinlets (stage I) and nodules (stage II) less than $0.5 \mathrm{~cm}$ in diameter. Thickness $25-120 \mathrm{~cm}$.

$3 \mathrm{Cn}$ horizon-Unaltered unit 3 (pl. 1C).

4Cn horizon-Unaltered unit 4 (pl. 1C).

$5 \mathrm{Cn}$ horizon-Unaltered unit 5 (pl. 1C).

\section{SOIL N (UPPER PLEISTOCENE)}

Very weakly developed (incipient) soil having A/Cn profile on oldest scarp colluvium (unit 6, pl. 1C). This soil's weak development indicates short time interval during which organic matter accumulated in graben prior to burial of soil $\mathrm{N}$ by units $2-5$.

6A horizon-Brown $(7.5 Y R 5 / 4 \mathrm{~d})$ to dark-brown (7.5YR4/4d), sandy loam having single-grain structure. Contains minor amount of organic matter, insufficient for ${ }^{14} \mathrm{C}$ dating.

6Cn horizon-Unaltered (not organic) unit 6, lightbrown (7.5YR6/4d), sandy loam.

\section{SOIL O (UPPER AND MIDDLE PLEISTOCENE)}

Strongly developed buried and relict soil consisting of Bt, Btca, K, and Cca horizons formed mainly on units 8 and 9 (pl. 1C). Soil also formed on unit 7, a local unit that intrudes lower units. Most of relict soil eroded from upper fault block near scarp but preserved on stable slope about $50 \mathrm{~m}$ west of trench headwall (profile T3-10). Buried soil (profile T3-14, lower part) formed until buried by unit 2 in response to faulting and subsequent scarp modification. Both soils have similar development and thickness where fully preserved. Descriptions and laboratory data for relict soil (profile T3-10) and buried soil (profile T3-14, lower part) are in tables 8 and 9 , respectively.

7Btca subhorizon-Light-brown to strong-brown (7.5YR5/5d), slightly calcareous, sandy clay loam having moderate, medium subangular blocky structure. Contains stage I and weak stage II calcium carbonate, probably derived from leaching of overlying unit (pl. 1C). Degree of development suggests this subhorizon formed long before burial by unit 2. Thickness about $60 \mathrm{~cm}$.

7Bca subhorizon-Light-brown (7.5YR6/4d), calcareous, sandy loam having weak, medium subangular blocky structure. Calcium carbonate is stage II (nodules). Thickness variable, as much as $1 \mathrm{~m}$.

8B2tca subhorizon-Yellowish-red (5YR4/6d), calcareous clay having strong, coarse subangular blocky structure. Red (2.5YR4/6d) clay films common on peds. Calcium carbonate is weak stage $I$ and forms filaments (or veinlets) within peds. Most carbonate accumulated after burial by unit 2 . Thickness $30-50 \mathrm{~cm}$, maximum $75 \mathrm{~cm}$ near fault.

8B3ca subhorizon-Light-brown (7.5YR6/4d), calcareous sandy clay loam having moderate, coarse subangular blocky structure. Few clay films on peds. Calcium carbonate is strong stage I to medium stage II (nodules). Thickness and presence of subhorizon variable, commonly $0-30 \mathrm{~cm}$.

9Bca subhorizon-Strong-brown (7.5YR5/6d) to lightbrown (7.5YR6/4d), calcareous sandy clay loam to sandy loam having moderate, medium subangular blocky structure. Subhorizon is in position of $9 \mathrm{~K} 2$ subhorizon but lacks strong carbonate accumulation (partly leached?). Carbonate is stage I and stage II. Locally includes thin, calcareous $8 \mathrm{Bt}$ horizon in upper part. Thickness commonly as much as $50 \mathrm{~cm}$, maximum $100 \mathrm{~cm}$.

9K1 subhorizon-Pinkish-white (7.5YR8/2d) to white, very calcareous, sandy clay loam having moderate, medium subangular blocky structure. Gradational upper part of master horizon of calcium carbonate accumulation (K horizon); weak stage III morphology. Thickness (0-15 cm) and development variable. 
9K2 subhorizon-White, very calcareous, sandy clay loam having moderate, medium subangular blocky structure. 9K2 subhorizon is main part of $\mathrm{K}$ horizon. Calcium carbonate stage III morphology; lacks platy structure or laminae. Thickness $35-45 \mathrm{~cm}$.

9K3 subhorizon-Pinkish-white (7.5YR8/2d), very calcareous to calcareous loam having moderate, medium subangular blocky to single-grain structure. Calcium carbonate stage III to strong stage II morphology having firm carbonate nodules. Irregular pendant-shaped lower boundary. Thickness commonly $5-20 \mathrm{~cm}$, maximum $100 \mathrm{~cm}$.

9Cca subhorizon-Pinkish-white (7.5YR8/2d) to strongbrown (7.5YR5.5/5d), calcareous, loamy sand having single-grain structure. Calcium carbonate stage II morphology grades down into noncalcareous material (9Cox subhorizon). Thickness $40-115 \mathrm{~cm}$.

9Cox subhorizon-Brown to strong-brown (7.5YR5.5/5d) sand having single-grain structure. Probably much like initial parent material (unit 9) except for slight reddening from oxidation of clay minerals. Present only in downdropped fault block. Thickness' 25-40 cm.

\section{SOIL P (MIDDLE PLEISTOCENE)}

Moderately developed calcareous buried soil on three thin deposits of alluvium (units 10-12, pl. 1C). Each soil subhorizon consists of a single alluvial unit. Soil thickness $80-90 \mathrm{~cm} ; 100 \mathrm{~cm}$ in isolated fault block. Soil on upthrown block consists of 10Btca (or 10Bt), 11Bca, and 12Cca subhorizons; soil within zone of faulting consists of largely undivided $10 \mathrm{Bca}$ and $12 \mathrm{Cn}$ subhorizons.

10Bt subhorizon-Yellowish-red (5YR5/6d), noncalcareous, sandy loam having moderate, medium subangular blocky structure. Subhorizon is leached variant of 10Btca subhorizon at shallow depth on scarp.

10Btca subhorizon-Pink (5YR7/4d), slightly calcareous, sandy loam having moderate, medium subangular blocky structure. Moderately developed calcium carbonate (stage I to weak stage II) probably derived from leaching of overlying 9Cca subhorizon. Thickness $35 \mathrm{~cm}$, top eroded.

10Bca subhorizon-Light-brown (7.5YR6/4d), slightly to moderately calcareous, sandy loam to loamy sand having moderate-medium to weak-medium subangular blocky structure. Calcium carbonate mostly stage II but also sparse stage III. May also contain some unit 11 (pl. 1C) in this largely undivided subhorizon. Thickness generally $60-75 \mathrm{~cm}$.

11 Bca subhorizon-Pink (7.5YR7/3d), calcareous, gravelly loamy sand having weak, medium subangular blocky structure. Calcium carbonate stage I to stage II morphology best developed in sandy lenses of unit 11 (pl. 1C). Not recognized as separate subhorizon in tilted fault block. Thickness 20-35 cm.

$12 \mathrm{Cca}$ subhorizon-Pinkish-white (7.5YR8/2d) to white, calcareous, loamy sand having moderate, medium subangular blocky structure. Weak stage III calcium carbonate morphology consists of continuously coated grains in carbonate-rich matrix. Thickness $20-30 \mathrm{~cm}$.

\section{SOIL $Q$ (MIDDLE PLEISTOCENE)}

Moderately developed, generally noncalcareous buried soil formed in alluvium that fills channels and burrows (or pipes), unit 13 (pl. 1C). Because soil Q is not calcareous, it probably formed or was transformed under pedalfer (leaching) conditions. Thickness $0-100 \mathrm{~cm}$, exclusive of oxidized parent material (13Cox subhorizon).

13B2t subhorizon-Reddish-yellow to yellowish-red (5YR5.5/6d), noncalcareous sandy loam having moderate, coarse to medium subangular blocky structure. Upper $10 \mathrm{~cm}$ slightly calcareous (stage I and weak stage II morphology); calcium carbonate probably added after burial by unit 12 . Weak clay films on ped faces. Thickness $0-60 \mathrm{~cm}$.

13B3 subhorizon-Reddish-yellow to strong-brown (7.5YR5.5/6d), noncalcareous, sandy loam to loamy sand having weak, medium subangular blocky structure. Generally noncalcareous but contains localized pods of calcium carbonate (weak stage III morphology), which may be remnants of formerly more extensive pedocal. Subhorizon surrounded by unit 14. Thickness $35-45 \mathrm{~cm}$.

13Cox subhorizon-Strong-brown (7.5YR5/6d), noncalcareous, slightly gravelly, loamy sand having single-grain structure. Mineral grains slightly oxidized from original parent material. Thickness about $100 \mathrm{~cm}$.

\section{SOIL R (MIDDLE OR LOWER PLEISTOCENE)}

Strongly developed argillic and calcic buried soil on unit 14 (pl. 1C), an upward-fining alluvial deposit. Soil $R$ is the most developed of all buried soils in upthrown fault 
block. Where not buried by unit 13 , soil $R$ continued to form while soil $Q$ (on unit 13) also formed. Soil $R$ is considerably less developed within zone of faulting, implying burial of soil $R$ during an early stage of its formation. $\mathrm{K}$ horizon thin over relatively impermeable $15 \mathrm{Bt}$ subhorizon of soil S. Thickness $75 \mathrm{~cm}$ (where eroded) to 120 cm.

14Bt subhorizon-Brown (7.5YR5/4d), noncalcareous, loamy sand having weak, medium angular blocky structure. Only exposed at base of trench in fault zone. Thickness $10 \mathrm{~cm}$ (or more).

14B2tca subhorizon-Shows laterally differential development due to partial burial by unit 13. Where buried (sample T3-6, pl. 1C), subhorizon is yellowishred (5YR5/6d), slightly calcareous, sandy clay loam having moderate, fine to medium subangular blocky structure. Where not buried, subhorizon is better developed and is red to yellowish-red $(4 Y R 4.5 / 6 \mathrm{~d})$, very slightly to slightly calcareous clay having strong, coarse to medium angular blocky structure and thick, common clay films on ped faces. Calcium carbonate is stage II morphology and increases in abundance down into 14B3tca subhorizon. Thickness $10 \mathrm{~cm}$ (where eroded) to $110 \mathrm{~cm}$.

14B3tca subhorizon-Light-brown (7.5YR6/3d) to light-reddish-brown (5YR6/4d), moderately calcareous, sandy clay loam(?) having moderate, medium angular blocky structure, few thin clay films, and calcium carbonate of stage II morphology. Thickness $15-35 \mathrm{~cm}$.

$14 \mathrm{~K}$ horizon-White to pinkish-white $(7.5 Y R 8 / 2 \mathrm{~d})$ and light-brown (7.5YR6/4d), mottled, calcareous sandy loam(?) having moderate, medium subangular blocky and locally massive structure. Predominately $\mathrm{K}$ horizon, but about 40 percent is Cca horizon material. Calcium carbonate has stage II and III morphology. Thickness $20-40 \mathrm{~cm}$, thickest where buried by unit 13 .

14Cca horizon-Light-brown to pinkish-gray (7.5YR6/3d), slightly calcareous sand having massive structure. Calcium carbonate disseminated (weak stage III morphology) in matrix of sand. Only present in fault zone as basal(?) horizon of soil $R$. Thickness greater than $15 \mathrm{~cm}$; base covered.

\section{SOIL S (MIDDLE OR LOWER PLEISTOCENE)}

Buried soil having a thick, moderately developed argillic $B$ horizon in unit 15 and thick calcareous Cca subhorizon in fine-grained part of unit 16 (pl. 1C). Contact between the two units is along textural and stratigraphic boundary; lower unit (16) coarser and more permeable than upper unit.

15Btca horizon-Reddish-yellow (5YR6/6d), slightly calcareous clay loam having moderate, medium to fine subangular blocky structure. Has stage I and weak stage II calcium carbonate derived from overlying soil R (14Cca horizon). Thickness $25-40 \mathrm{~cm}$.

16Cca subhorizon-Light-brown (7.5YR6/4d), calcareous, sandy clay loam to calcareous, sandy loam (near base) having moderate, medium to fine subangular blocky structure. Stage II calcium carbonate in nodules and disseminated in matrix. Upper $15 \mathrm{~cm}$ has pods of Bt, indicating Cca probably has engulfed former 16Bt subhorizon. Thickness $75-170 \mathrm{~cm}$.

$16 \mathrm{Cn}$ subhorizon-Unaltered to slightly calcareous, coarse-grained gravelly sand; forms discontinuous wedge within sandy main body of unit 16 . Thickness as much as $65 \mathrm{~cm}$.

\section{SOIL T (MIDDLE OR LOWER PLEISTOCENE)}

Poorly exposed buried soil at base of trench in upthrown fault block. Soil probably has Cca or $\mathrm{K}$ horizons below Bt horizon but lower horizons not exposed. Detailed description of unit 17 on pl. 1C. Thickness unknown.

$17 \mathrm{Bt}$ horizon-Yellowish-red (5YR4.5/6d), noncalcareous, sandy clay loam to clay having strong, coarse subangular blocky structure; contains mottles and rootlets(?) of dark-gray manganese or organic matter(?). Ped faces have weak clay films; granules and pebbles have thick clay coatings. Thickness more than $30 \mathrm{~cm}$; base not exposed.

\section{DESCRIPTION OF SOIL HORIZONS IN TRENCH 4}

Cn horizon-Unaltered unit 1 (pl. 1D).

2Cn horizon-Unaltered unit 2 (pl. 1D).

3Cn horizon-Unaltered unit 3 (pl. 1D).

SOIL V (UPPER HOLOCENE)

Buried, very weakly developed soil in eolian sand (unit 4, pl. 1D). Soil has single nonargillic, noncalcareous B horizon formed during short period of surface stability. Soil displaced by fault at $12.8 \mathrm{~m}$ from headwall of trench 4. Laboratory data for soil V (profile T4-22, upper part) is in table 16 . 
4B horizon-Light-brown to pink (7.5YR6.5/4d), noncalcareous sand having weak, medium subangular blocky structure. Dry consistence is friable, not loose, indicating weak but minor accumulation of clay. Thickness $15-30 \mathrm{~cm}$.

4 Cn horizon-Unaltered unit 4; light-brown (7.5YR6/4d), loose, noncalcareous sand having single-grain structure. Thickness about $35 \mathrm{~cm}$.

\section{SOIL W (HOLOCENE)}

Weakly developed soil on unit 5 , a widespread blanket of eolian sand of early Holocene to latest Pleistocene age. Soil has A horizon and Bt and (or) Bca subhorizons. Best developed as relict soil (profile T4-1, upper part) on upthrown fault block. Buried component (profile T4-21, upper part, and profile T4-22, lower part) has less clay and weaker structure but is slightly calcareous. Soil description and laboratory data for relict soil are in table 13; laboratory data for buried components are in tables 15 and 16.

$5 \mathrm{~A}$ horizon-Light-brown to yellowish-brown $(9 Y R 5 / 5 \mathrm{~d})$, loose, noncalcareous sand having single-grain structure and weak accumulation of organic matter. Only preserved at surface of upthrown fault block. Thickness $0-10 \mathrm{~cm}$.

5Bt subhorizon-Brown (7.5YR4.5/4d) to reddishyellow (7.5YR5/5d), noncalcareous, loamy sand to sandy loam having weak, fine subangular blocky structure. Few thin clay films on sand grains. Dry consistence firm to friable. Includes undifferentiated 20-cm-thick 5Cox horizon, light-brown to brown (7.5YR5.5/4d), loose, noncalcareous, loamy sand at base of $5 \mathrm{Bt}$ horizon in upthrown block. Thickness about $60 \mathrm{~cm}$ in upthrown block, $25-65 \mathrm{~cm}$ in fault zone, and as much as $1 \mathrm{~m}$ in downdropped block.

5Btca subhorizon-Strong-brown to reddish-yellow (7.5 YR6/5d), slightly calcareous, sandy loam having weak, medium subangular blocky structure. Few thin clay films on sand grains. Calcium carbonate stage I (veinlets) and weak stage II (few small nodules). Calcareous variant of $B$ horizon only preserved where buried by younger units. Thickness variable, as much as $40 \mathrm{~cm}$.

\section{SOIL X (UPPER PLEISTOCENE)}

Moderately developed buried soil on scarp colluvium (units 6 and 7). Only present within and on downdropped side of fault zone. Resembles soil Y (formed in older units, 9-12, pl. 1D) but only represents last part of time soil Y was forming. Laboratory data for soil X (profile T4-21, lower part) is in table 15.

6B2t subhorizon-Yellowish-red $(6 Y R 5 / 6 \mathrm{~d})$ to strongbrown (6YR4/6d), noncalcareous, sandy loam having moderate, medium subangular blocky structure. Lower contact based on presence of calcium carbonate. Thickness variable, $0-35 \mathrm{~cm}$.

6B3tca subhorizon-Yellowish-red (5YR5/6d), slightly calcareous, sandy clay loam having moderate to strong, medium to coarse subangular blocky structure. Stage I calcium carbonate coats grains and ped faces. Although subhorizon is designated B3 based on position, laboratory analyses show it is most clay-enriched part of $6 \mathrm{Bt}$ horizon. Thickness variable, $0-45 \mathrm{~cm}$.

7K horizon-White to pink (5YR7/3d), calcareous, sandy clay loam to calcareous, sandy loam (near base) having strong to moderate, coarse to medium subangular blocky structure in upper part. Stage III calcium carbonate forms continuously coated soil matrix near top of horizon, grading down to weak stage III at base of horizon. $\mathrm{K}$ horizon was subdivided for sampling. Thickness $20-75 \mathrm{~cm}$.

7Cca horizon-Pink to pinkish-gray (7.5YR7/3d), calcareous, sandy loam to slightly calcareous, loamy sand having weak, medium subangular blocky to single-grain structure. Stage I and stage II calcium carbonate have hard nodules $1-2 \mathrm{~cm}$ in diameter. Thickness and occurrence variable, 0-45 $\mathrm{cm}$.

7Cn subhorizon-Unaltered unit 7; light brown to pink (7.5YR6.5/4d), loamy sand having single-grain structure. Contains chunks of former $9 \mathrm{Bt}$ and $10 \mathrm{Cca}$ horizons of soil Y (pl. 1D) on upthrown fault block. Thickness 50-100 cm.

$8 \mathrm{Cn}$ horizon-Unaltered unit 8 (pl. 1D).

SOIL Y (relict, UPPER AND MIDDLE PLEISTOCENE; buried, MIDDLE PLEISTOCENE)

Soil consists of two buried components on units 9-12. Soil on upthrown fault block, west of $9 \mathrm{~m}$ from trench headwall (pl. 1D; profile T4-1, lower part), was recently buried by unit 5 and is better developed of two components. Soil on downdropped fault block (east of 10.4 $m$ from trench headwall, pl. 1D) was faulted and subsequently buried by units 6,7 , and 8 ; soil was not exposed in trench but was found just below $8 \mathrm{Cn}$ horizon in auger 
holes adjacent to trench. Soil description and laboratory data (profilie T4-1, lower part) is in table 14.

9B2t subhorizon-Yellowish-red (5YR5/6d), noncalcareous, sandy loam to sandy clay loam having strong to moderate, coarse to medium subangular blocky structure and few to common, thin clay films on ped faces. Lower contact based on presence of calcium carbonate. Thickness $20-40 \mathrm{~cm}$.

9B3tca subhorizon-Yellowish-red (5YR5/6d to $5 Y R 4.5 / 6 \mathrm{~d})$, slightly calcareous, sandy clay loam having strong, coarse to medium subangular blocky structure and common thin to thick clay films on ped faces. Stage I to stage II calcium carbonate coats some peds. Thickness variable, $0-55 \mathrm{~cm}$.

10Bt subhorizon-Yellowish-red (5YR5/6d) to reddishyellow (5YR6/6d), noncalcareous, sandy clay loam to sandy loam (at base) having moderate, medium subangular blocky structure and few thin clay films on peds. This subhorizon and the $10 \mathrm{Bca}$ subhorizon fill depressions in adjacent $\mathrm{K}$ and Cca horizons of unit 11; depressions are eolian-sand-filled dissolution or collapse pipes and (or) animal burrows (crotovinas). Degree of development of $10 \mathrm{Bt}$ and 10Bca subhorizons within depressions compared to adjacent subhorizons suggests that $10 \mathrm{Bt}$ and $10 \mathrm{Bca}$ subhorizons formed after $11 \mathrm{~K}$ horizon but before deposition of unit 9, an eolian unit. Thickness $75 \mathrm{~cm}$.

10Bca subhorizon-Light-reddish-brown (5YR6/4d) to light-brown $(7.5 Y R 6 / 4 \mathrm{~d})$, slightly calcareous to calcareous, sandy clay loam to loamy sand (at base) having moderate, medium subangular blocky structure in upper part. Calcium carbonate is discontinuous, stage I (veinlets) to stage II (nodules). Thickness and occurrence variable, $25-130 \mathrm{~cm}$.

$11 \mathrm{~K}$ horizon-Strongly calcareous horizon, undivided between 8 and $11 \mathrm{~m}$ from trench 4 headwall (pl. 1D) and consisting of $11 \mathrm{~K} 2$ and $11 \mathrm{~K} 3$ subhorizons or thin, disrupted bodies of these subhorizons.

$11 \mathrm{~K} 2$ subhorizon-White $(5 Y R 8 / 1 \mathrm{~d})$, calcareous, sandy clay loam to sandy loam (at base) having moderate to weak, medium subangular blocky structure. Calcium carbonate has moderate stage III morphology, disseminated in continuous matrix. Thickness 25-100 cm.

$11 \mathrm{~K} 3$ subhorizon-White (5YR8/1d) to light-brown (7.5YR6.5/4d), calcareous, sandy loam to loamy sand having moderate, medium subangular blocky to single-grain structure in lower part. Calcium carbonate grades from moderate and weak stage III down into mixture of stage I and stage II. Thickness $40-75 \mathrm{~cm}$.

11Cca horizon-White (7.5YR8/1d) and pink to lightbrown (7.5YR6.5/4d), slightly calcareous, loamy sand having single-grain structure. Calcium carbonate is mainly disseminated nodules (stage II) making up 10-20 percent of the horizon's volume. Soil matrix appears slightly oxidized where less calcareous. Thickness $0-45 \mathrm{~cm}$, thickest where overlying $\mathrm{K3}$ subhorizon not well developed.

12Cca horizon-Largely undivided, slightly calcareous, loamy sand to gravelly sand having single-grain structure. Mapped only in fault zone, where it is widely disrupted.

12C1ca subhorizon-Light-brown (7.5YR6/4d), slightly calcareous, gravelly loamy sand to very gravelly sand having single-grain structure. Calcium carbonate discontinuous; forms small isolated masses of stage I (coatings on clasts) to stage III morphology. Subhorizon boundaries at depositional contacts between alluvial facies of unit 12. Thickness $10-60 \mathrm{~cm}$.

12C2ca subhorizon-Light-brown (7.5YR6.5/3d), slightly calcareous, slightly gravelly (pebble) sand having massive structure. Calcium carbonate stage II to stage III in fine-grained facies of unit 12. Thickness about $40 \mathrm{~cm}$.

$12 \mathrm{C} 3 \mathrm{ca}$ subhorizon-Light-brown $(7.5 Y R 6 / 3 \mathrm{~d})$ to brown (7.5YR5/4d), gravelly (pebble) sand to very gravelly (cobble) sand having single-grain structure. Calcium carbonate mainly stage I (coatings on clasts). Thickness $35-50 \mathrm{~cm}$.

12Cox subhorizon-Light-brown (7.5YR6/4) to strongbrown (7.5 YR5/6d), slightly gravelly, sand to loamy sand having single-grain structure. Generally noncalcareous and slightly oxidized. Basal subhorizon of soil Y. Thickness $10-40 \mathrm{~cm}$.

13Cn horizon-Unaltered unit 13 (pl. 1D).

$14 \mathrm{Cn}$ horizon-Unaltered unit 14 (pl. 1D).

\section{SOIL Z (MIDDLE OR LOWER PLEISTOCENE)}

Moderately well developed argillic and calcic buried soil. Similar to soil $\mathrm{X}$ in developmental strength. Truncated and buried by unit 14. Oldest soil exposed in trench 4; 
marks old, stable surface of piedmont slope. Detailed description of units 15 and 16 on plate $1 D$.

15Btca subhorizon-Yellowish-red (5YR4.5/6d), slightly calcareous, sandy clay loam having moderate, fine angular blocky structure. Calcium carbonate is stage I and stage II (nodules less than $1 \mathrm{~cm}$ in diameter). Lower $13 \mathrm{~cm}$ more calcareous (stage II), reddish-yellow to light-reddish brown (5YR6.5/5d) and white. Top of subhorizon eroded. Thickness $22 \mathrm{~cm}$.

$15 \mathrm{~K}$ horizon-White and light-reddish-brown (5YR6/4d; 10-20 percent of the horizon's volume), calcareous, slightly gravelly, sandy clay loam having moderate to strong, medium subangular blocky structure. Calcium carbonate is stage III and hard. Thickness $20-22 \mathrm{~cm}$.

$15 \mathrm{Cca}$ horizon-Pinkish-gray to pink (7.5YR7/2.5d), calcareous to slightly calcareous, sandy loam having massive to single-grain structure. Calcium carbonate grades from weak stage III at top to stage II near base. Thickness $50 \mathrm{~cm}$.

16Coxca horizon-Pink (7.5YR7/3d), slightly calcareous and oxidized sand having single-grain structure. Calcium carbonate (stage I, veinlets) probably accumulated after sand was oxidized. Lowest exposed part of soil Z. Base not exposed. Thickness at least $20 \mathrm{~cm}$. 



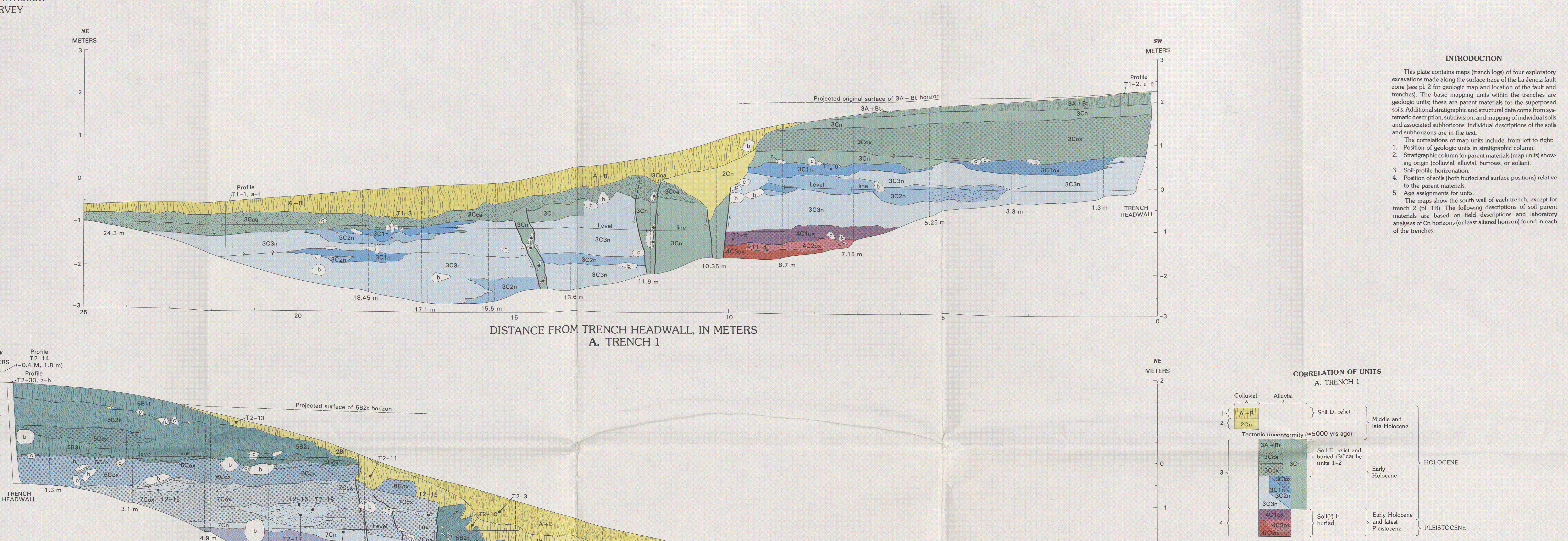

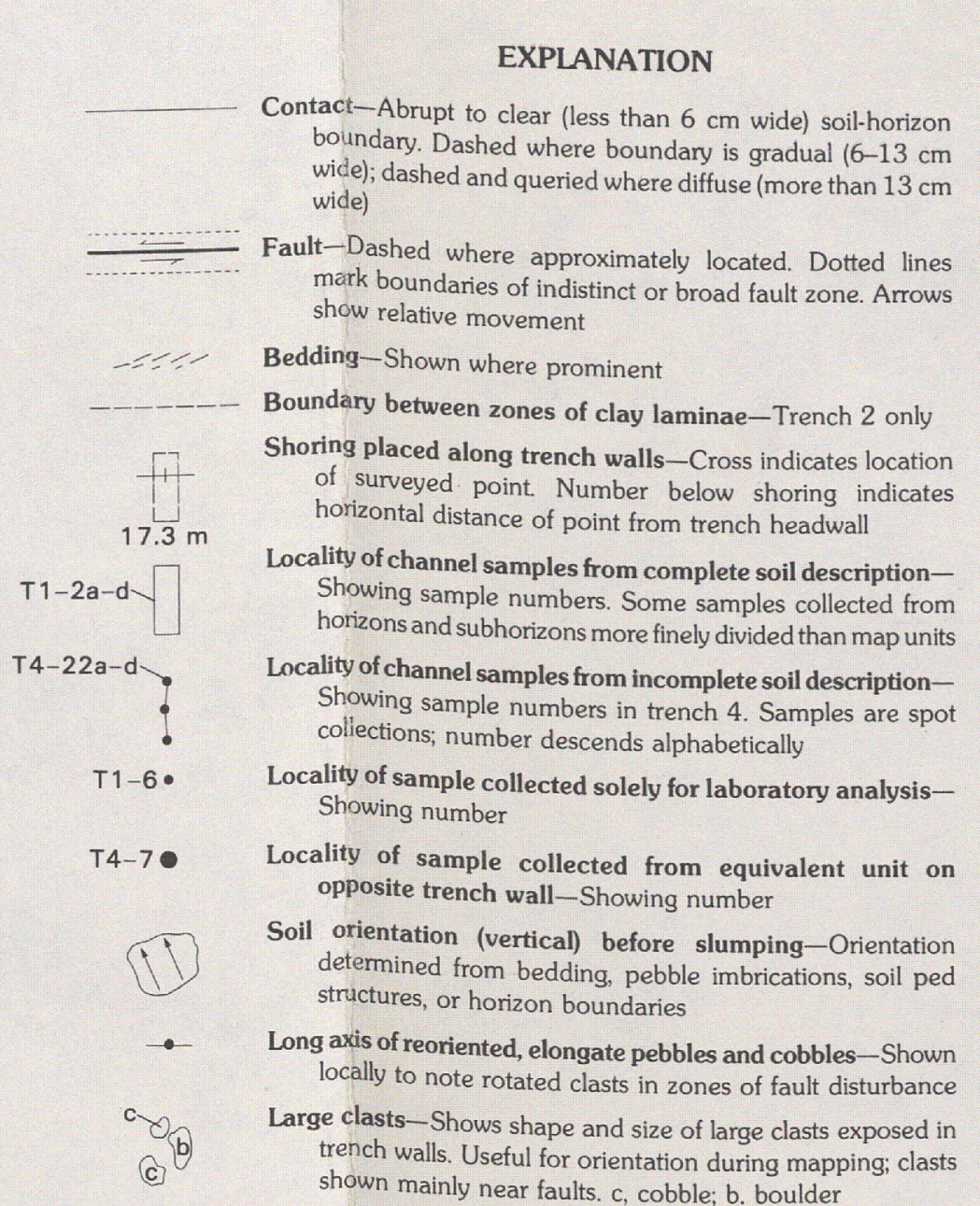

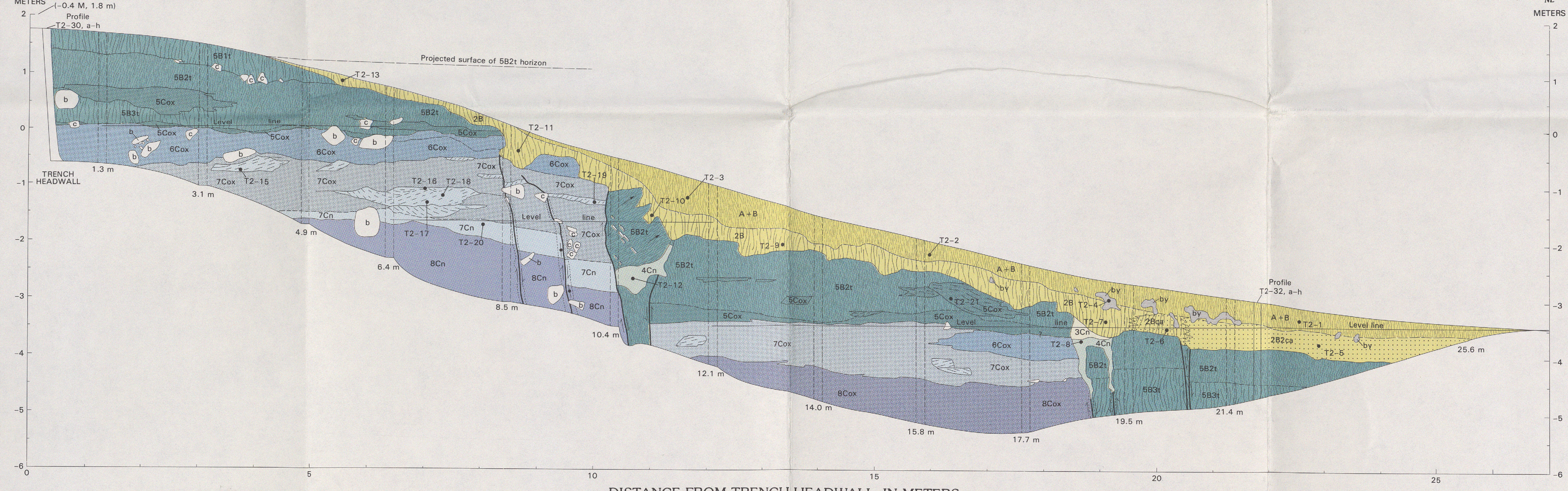

DSTANCE FROM TRENCH HEADWALL IN METERS
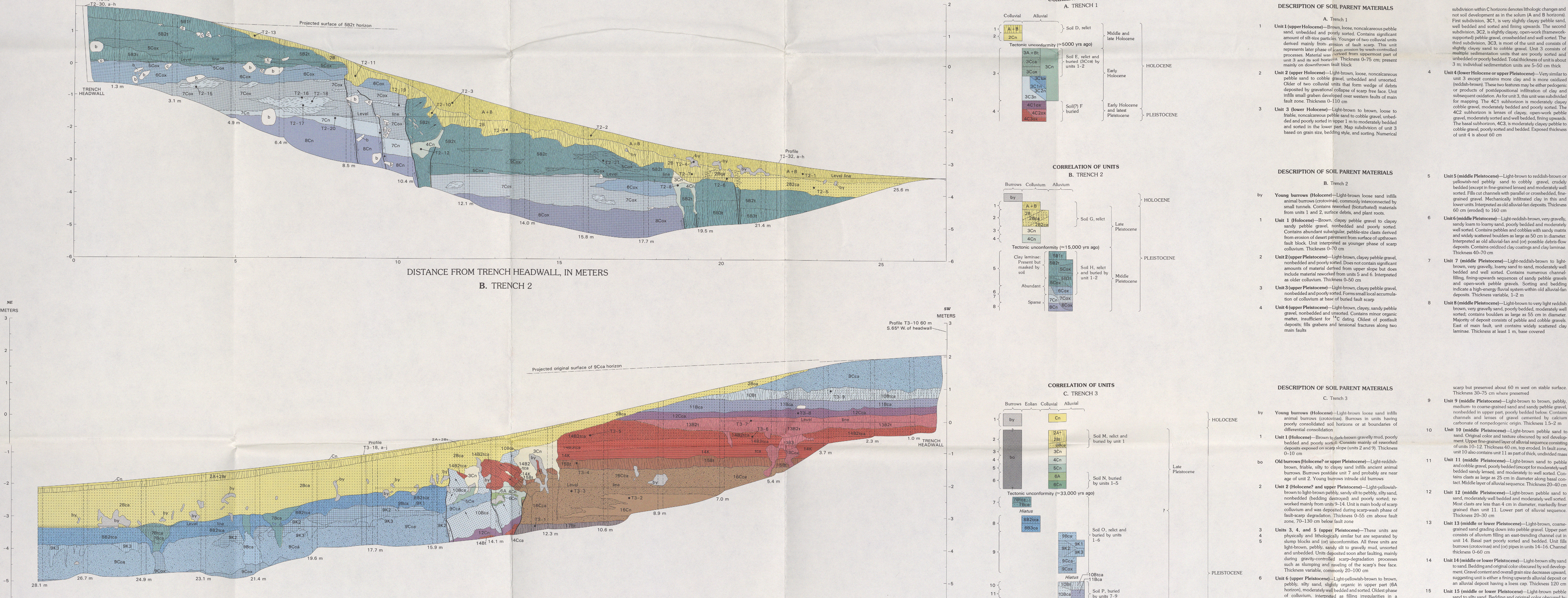

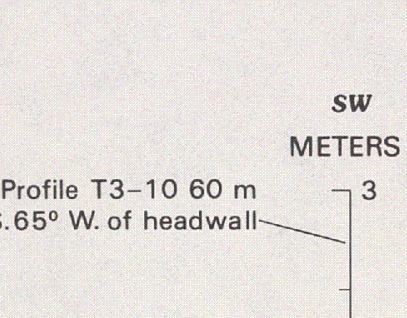

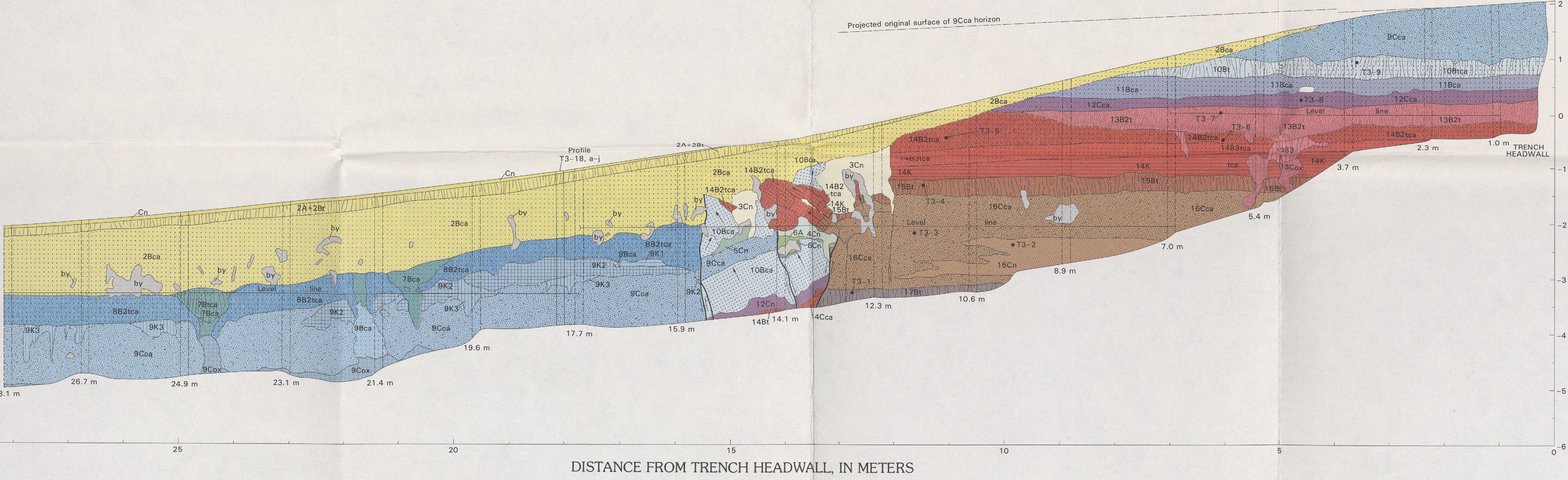

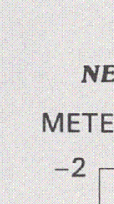
DISTANCE FROM TRENCH HEADWALL, IN METERS

C. TRENCH 3

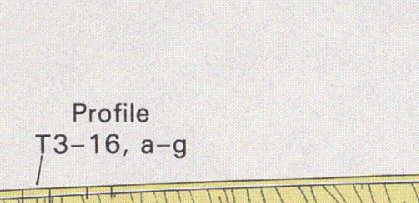

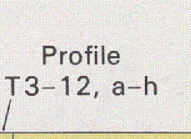

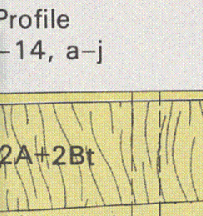

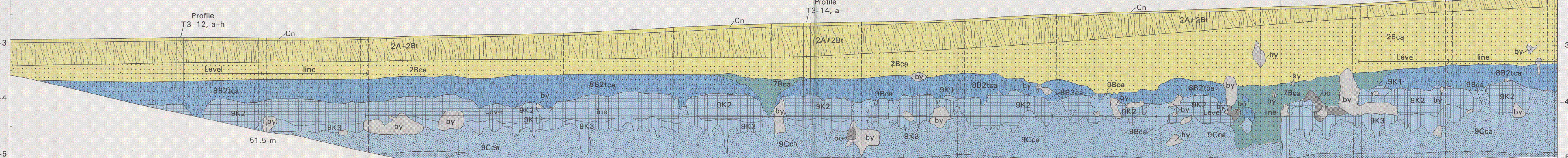

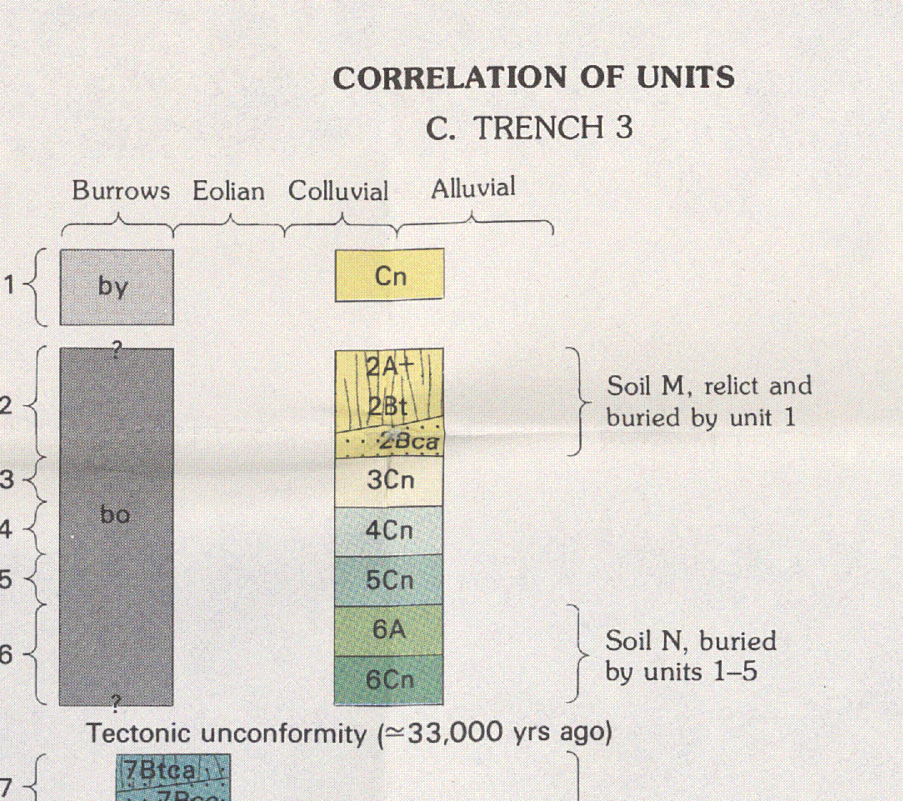

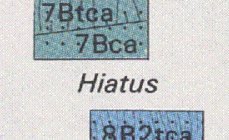

arazeat

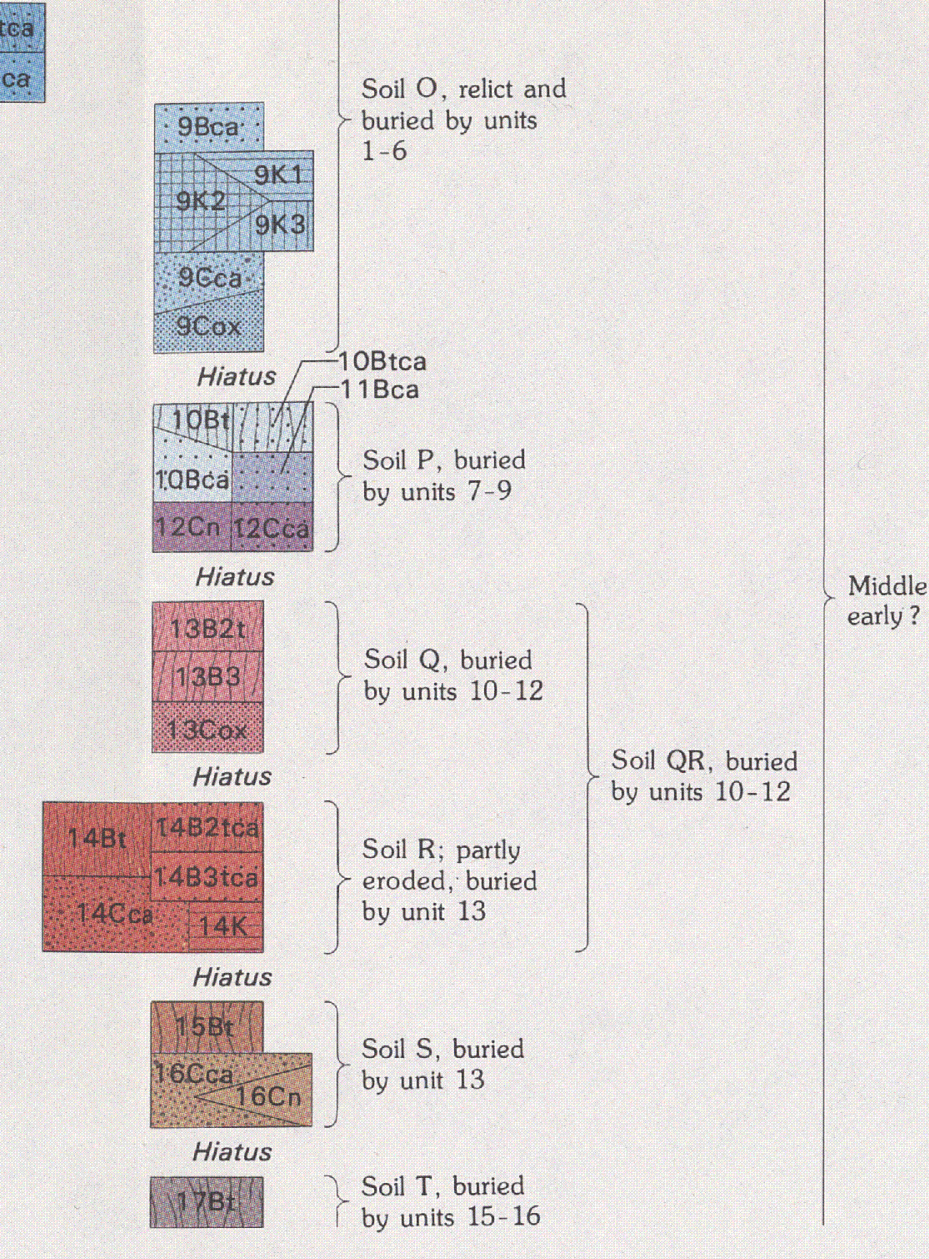
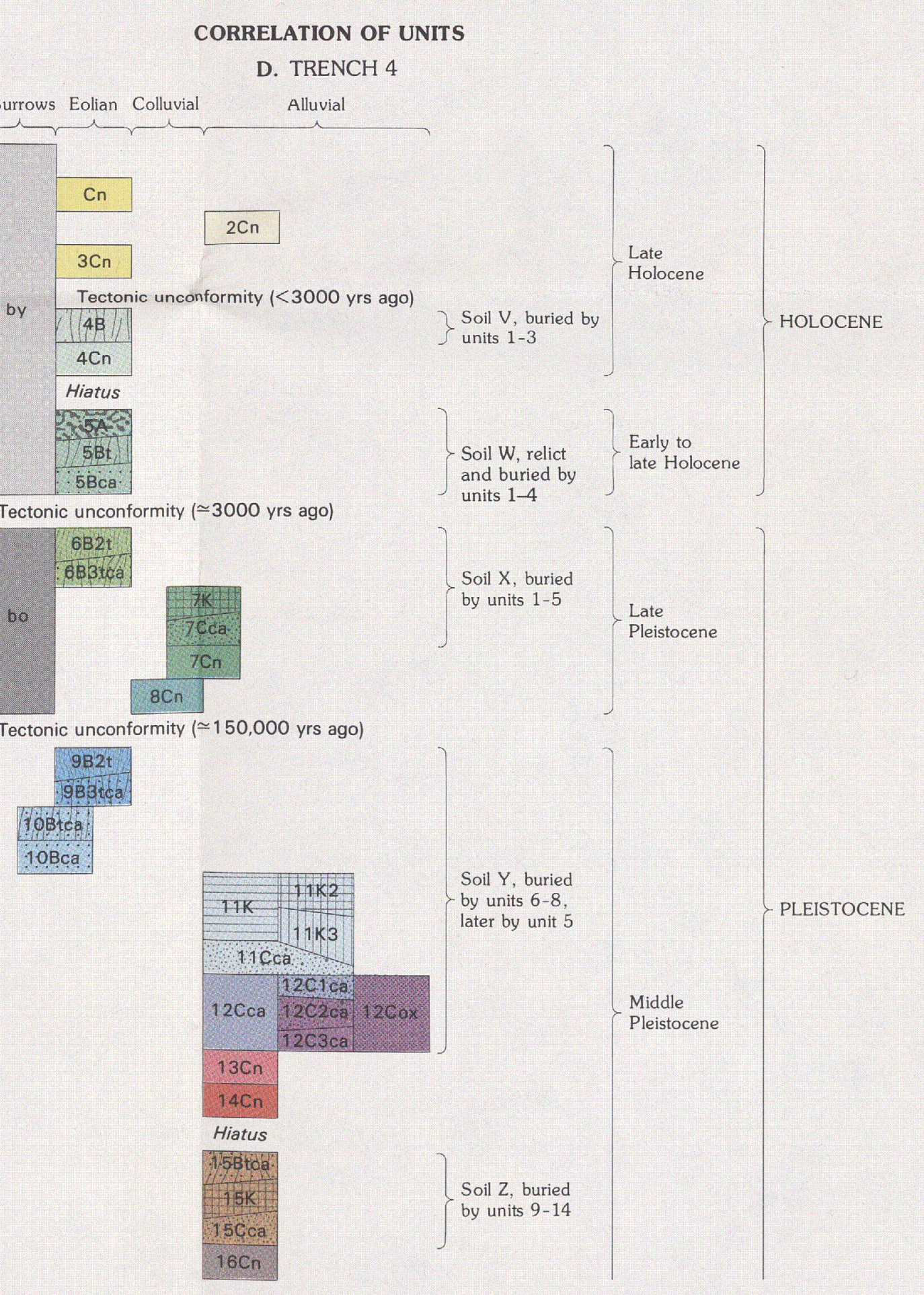
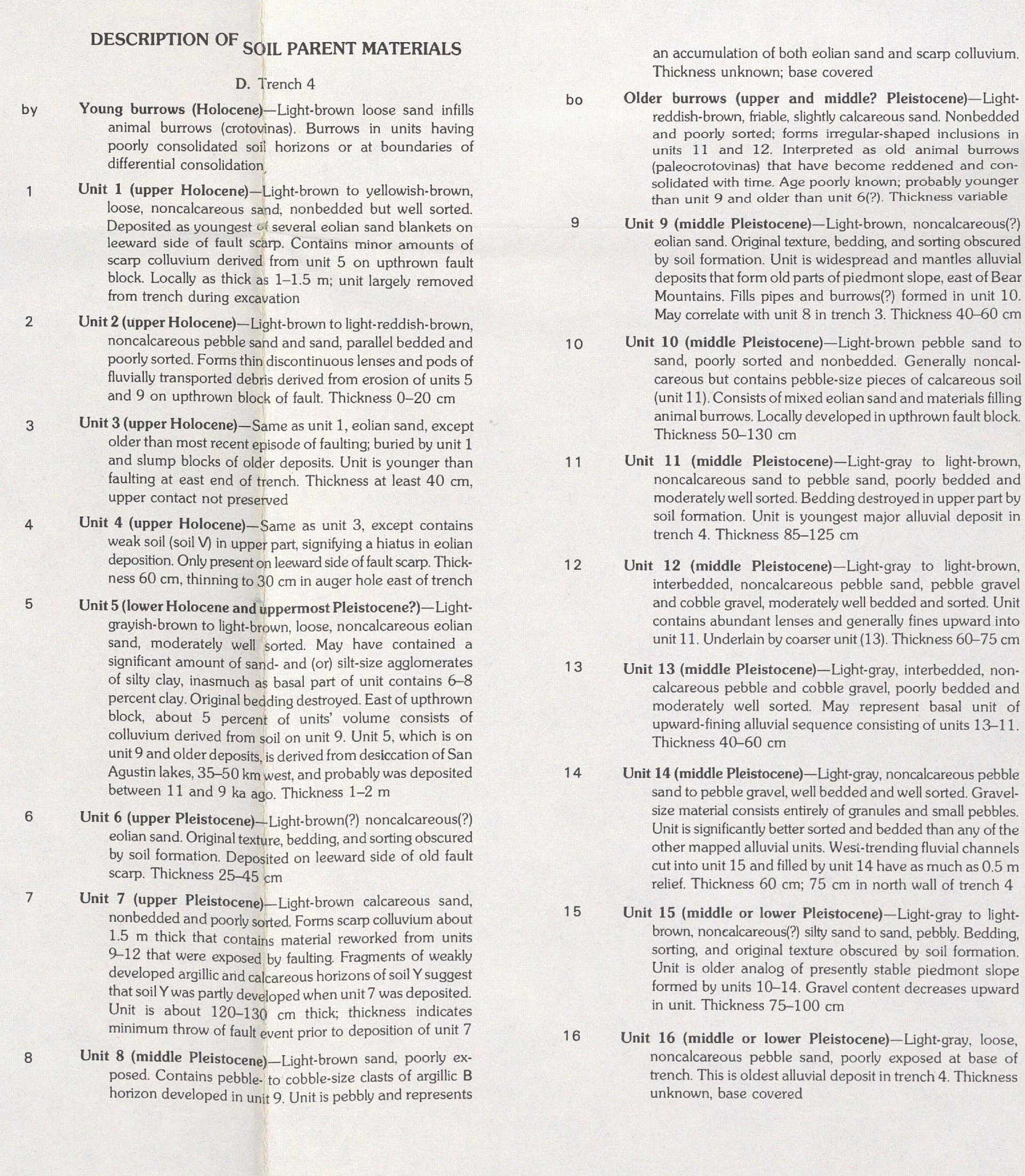

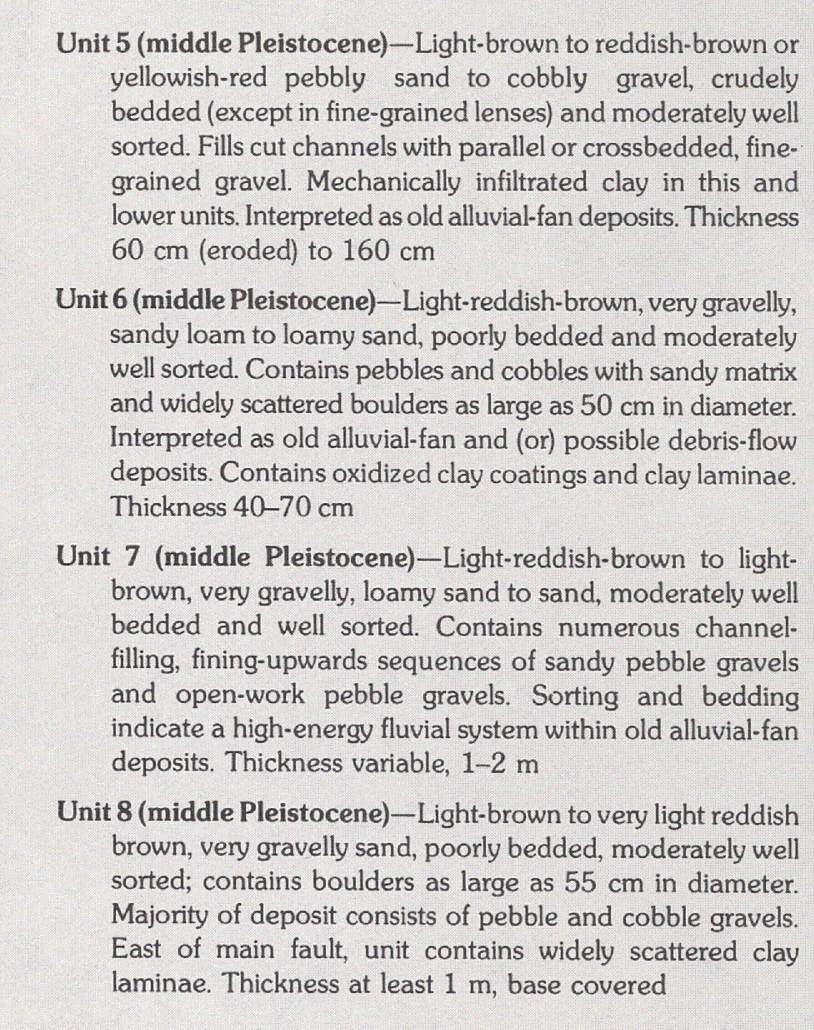

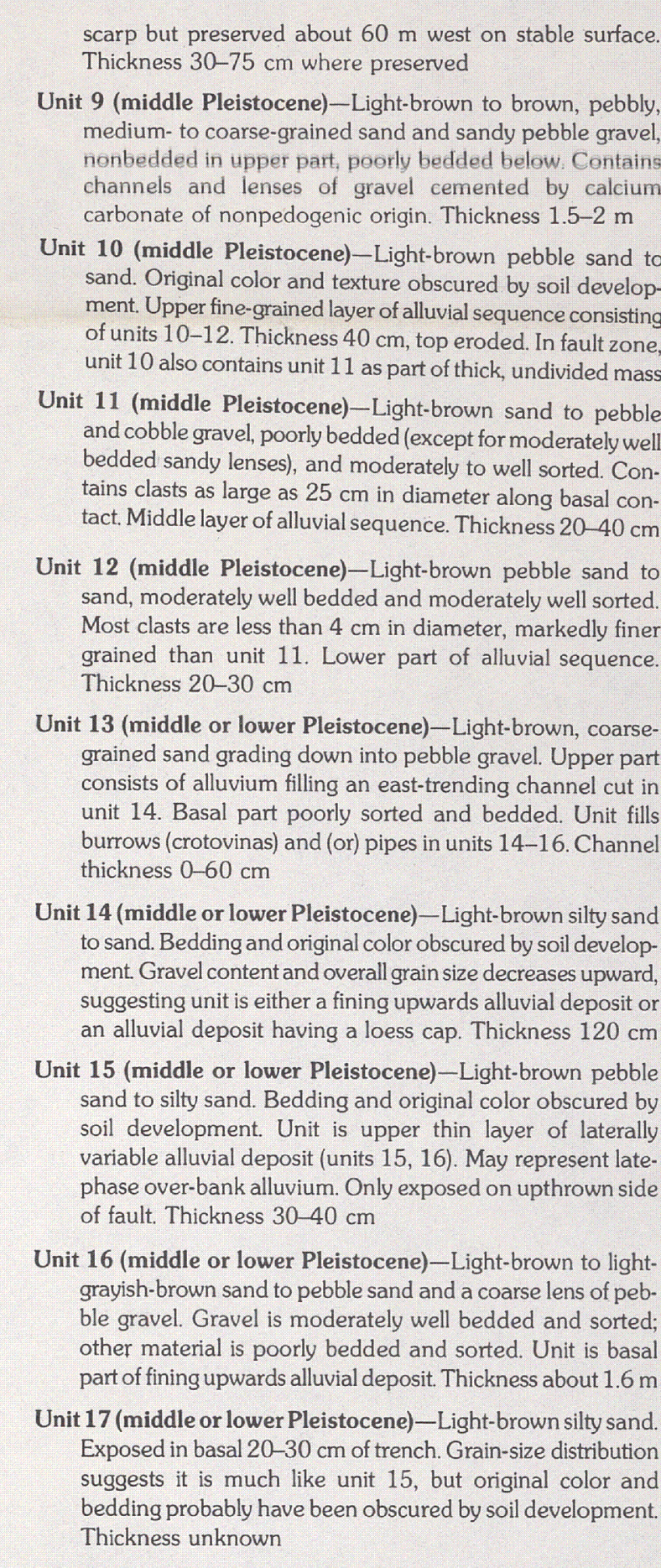

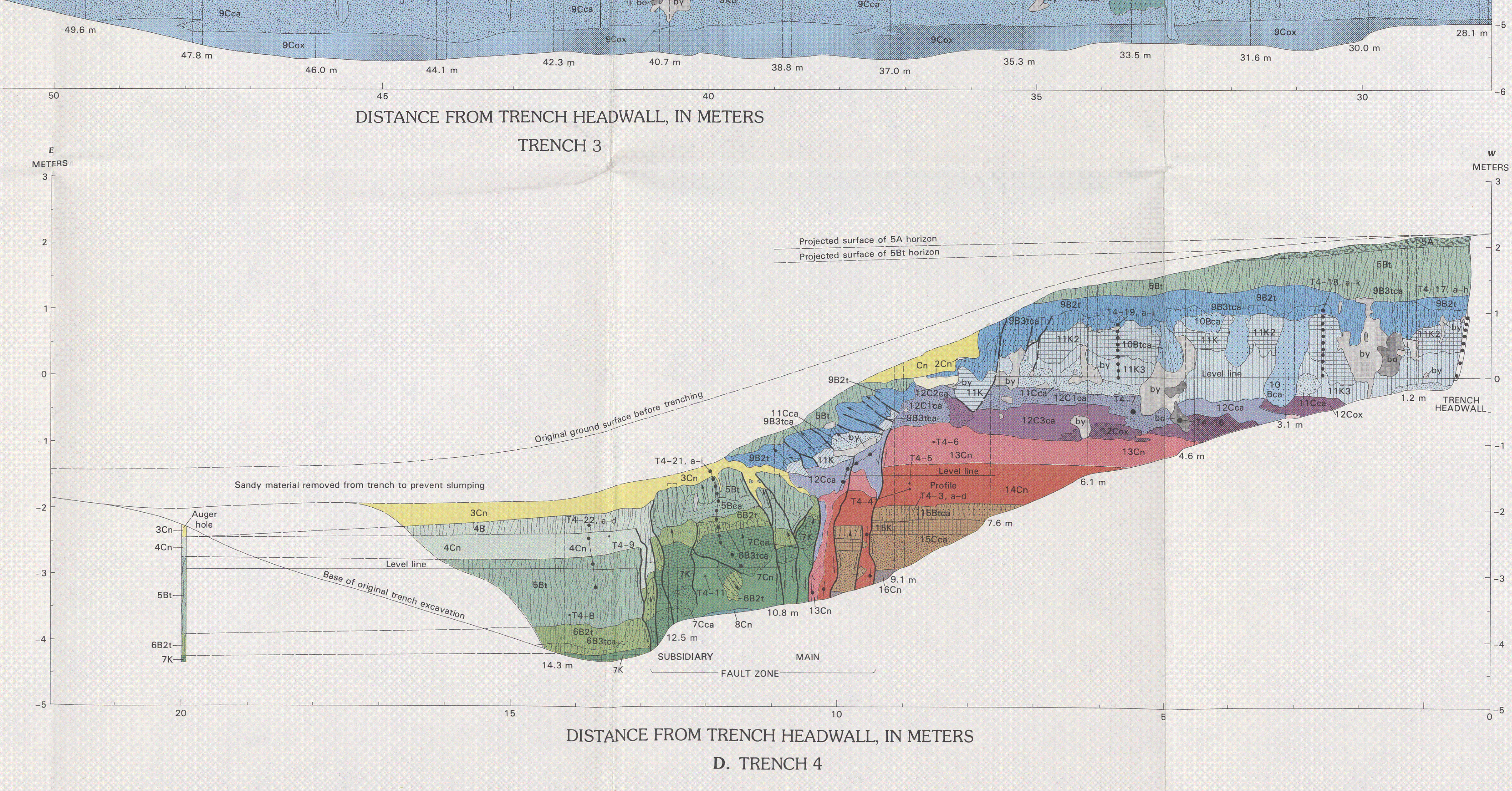





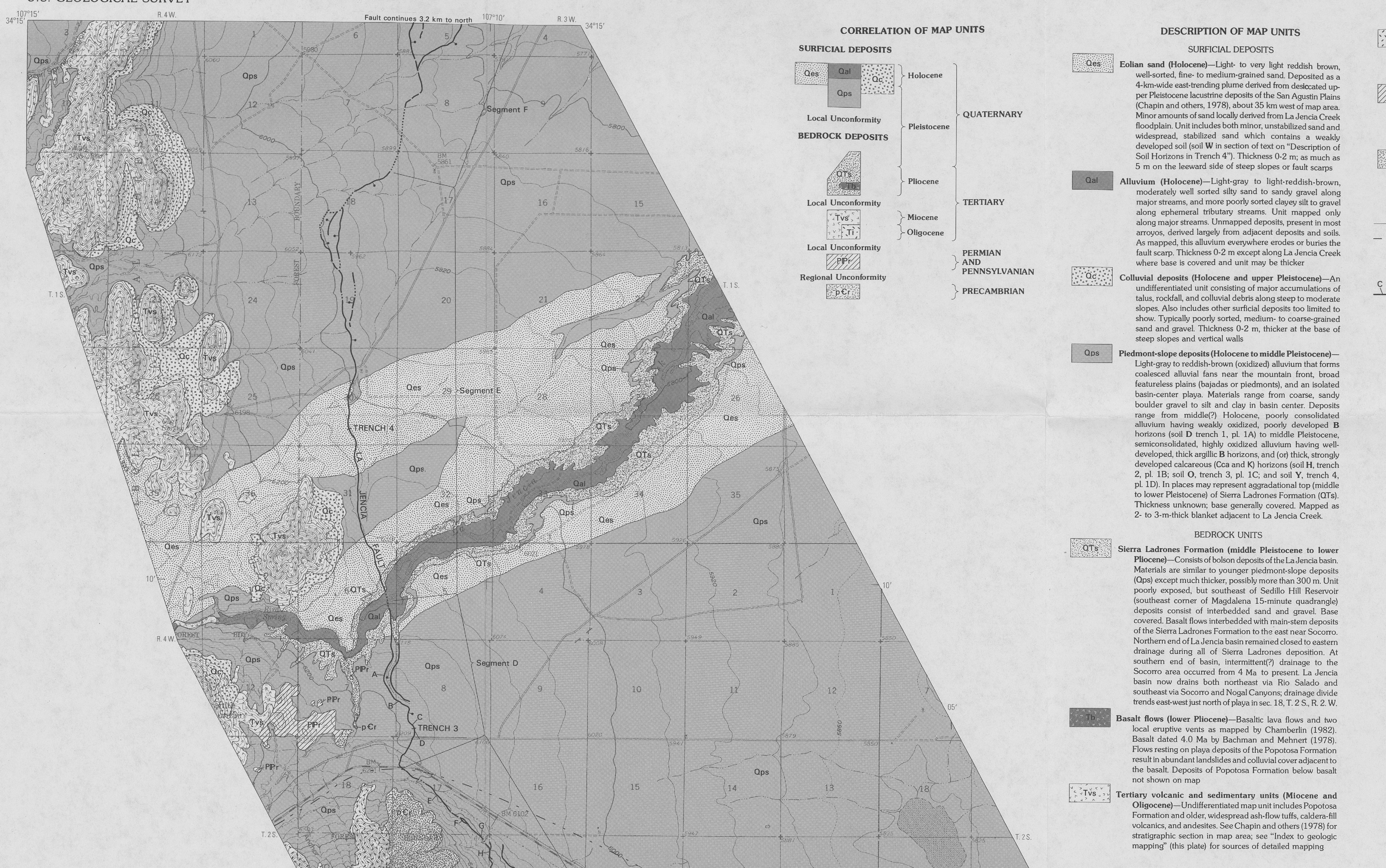

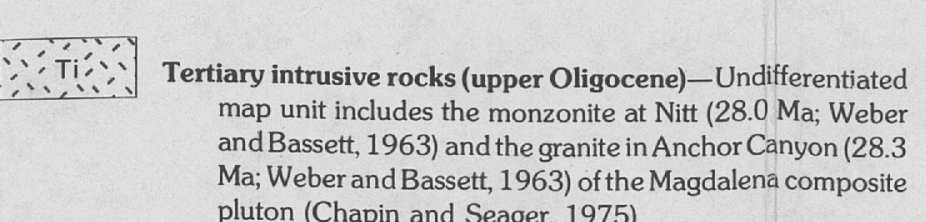

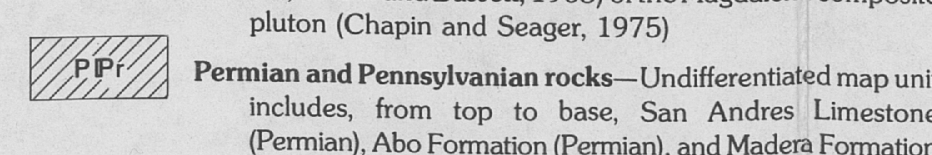

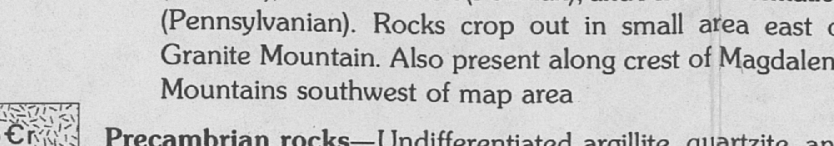

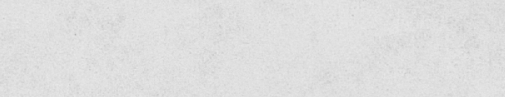

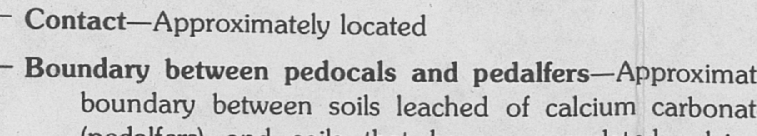

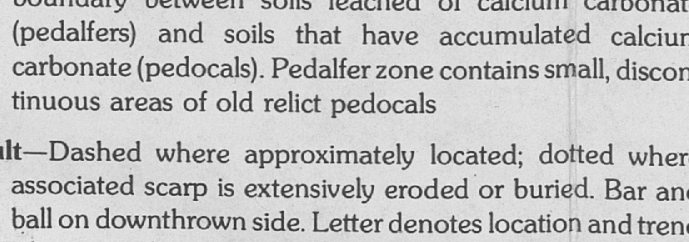

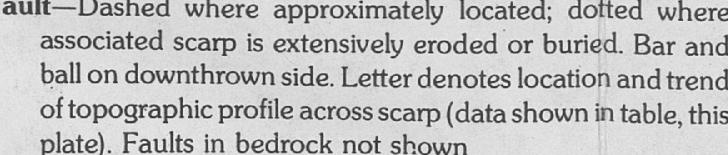

RerFereces crite

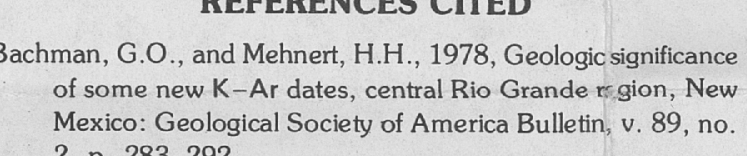

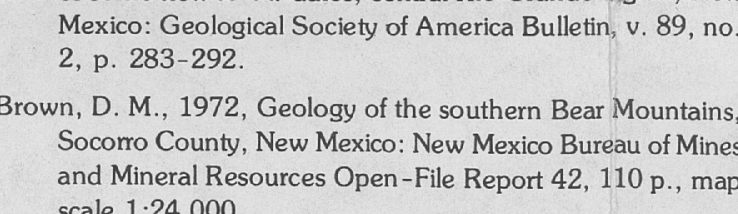

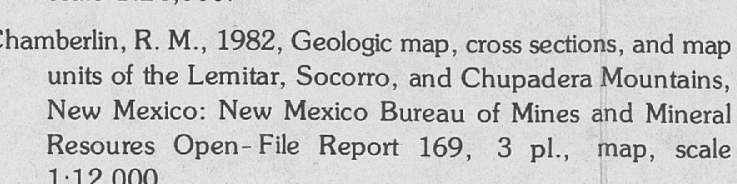

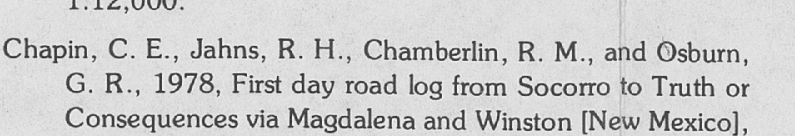

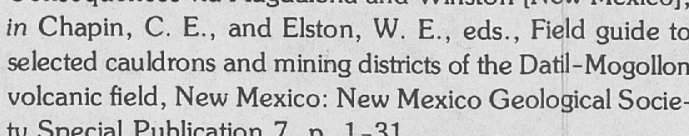

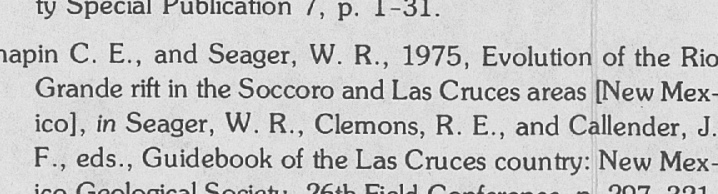

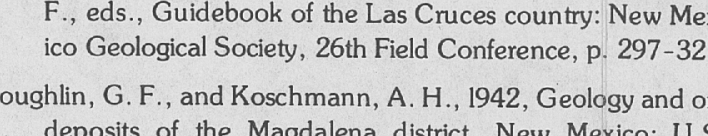

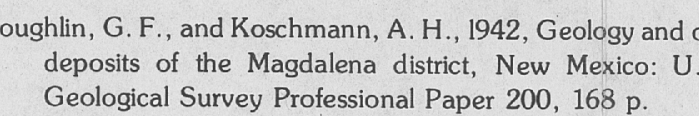

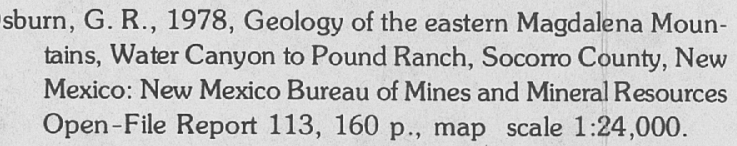

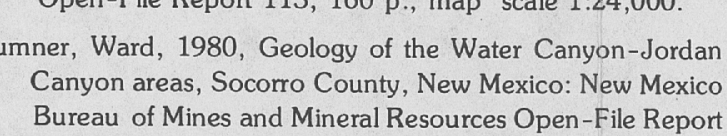

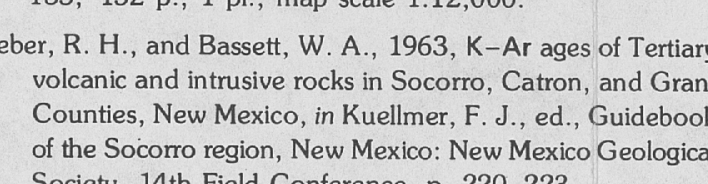

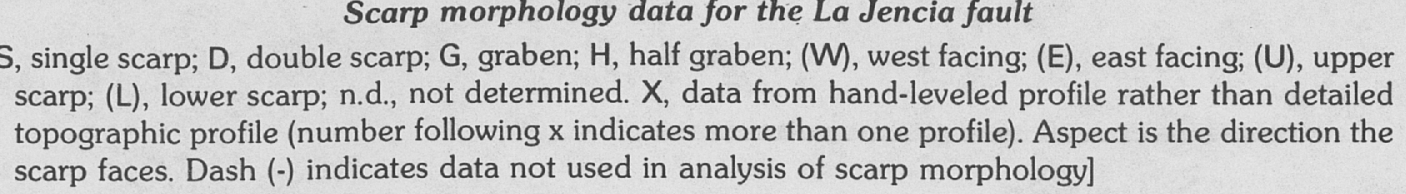

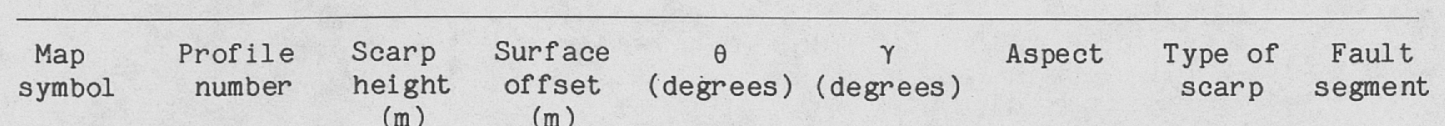

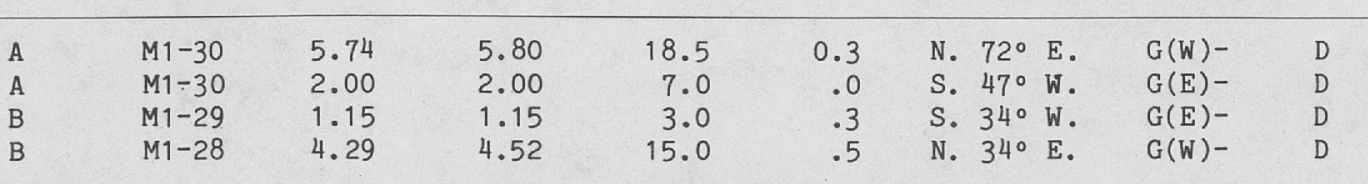

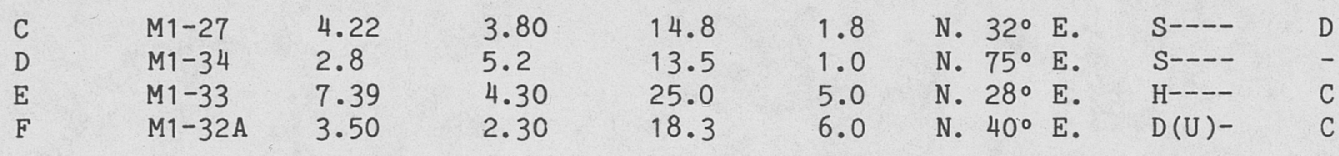

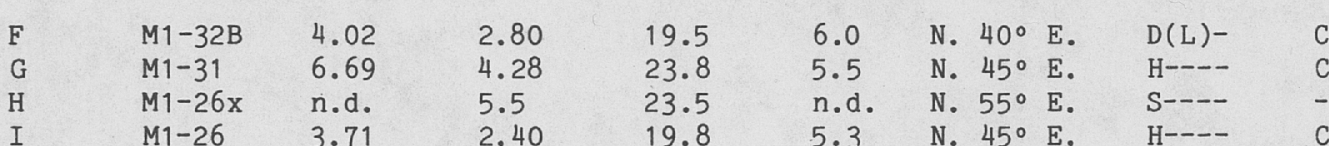

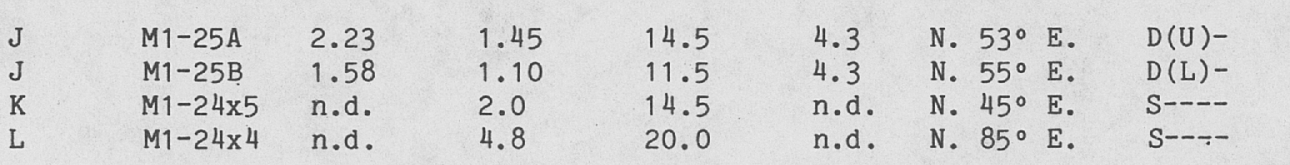

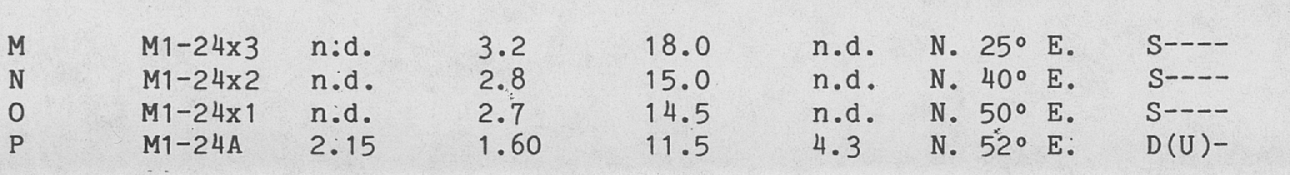

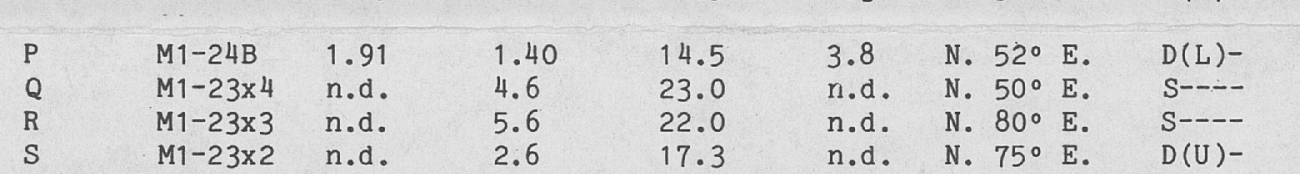

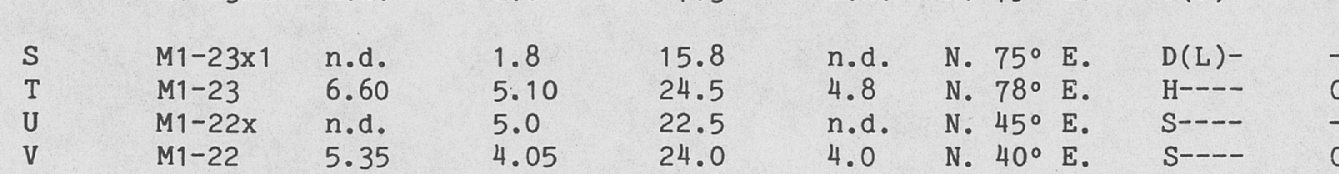

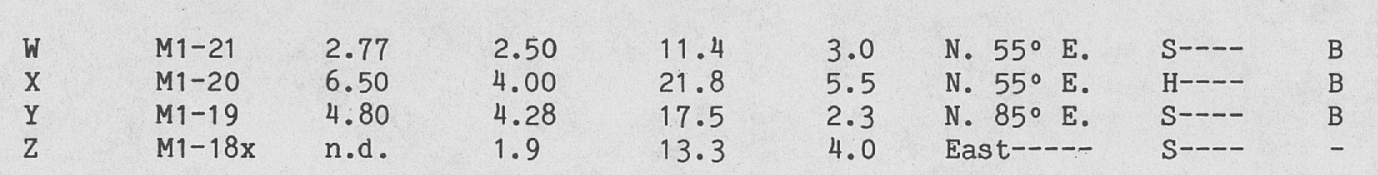

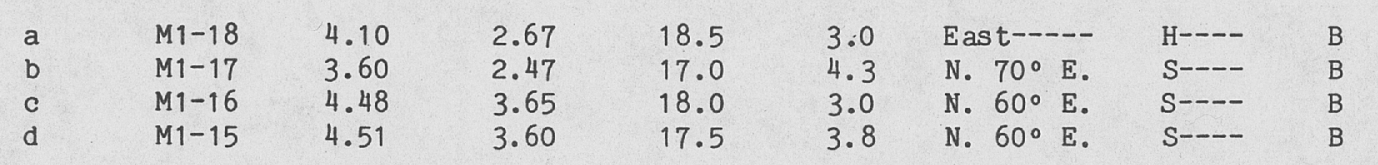

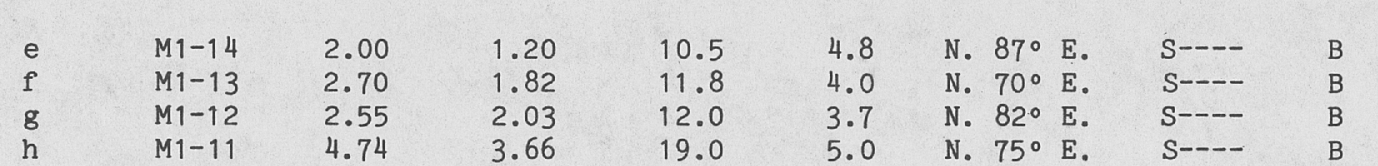

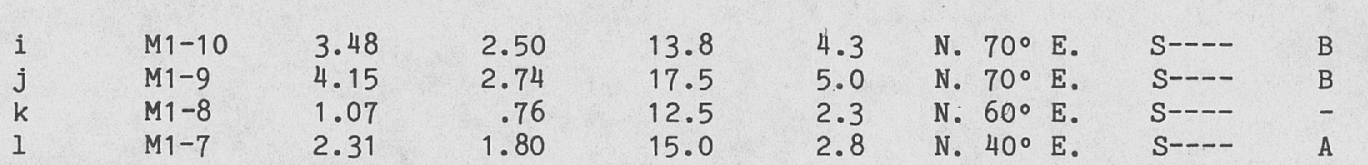

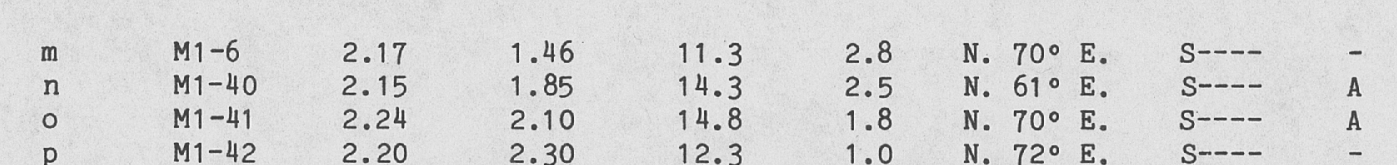

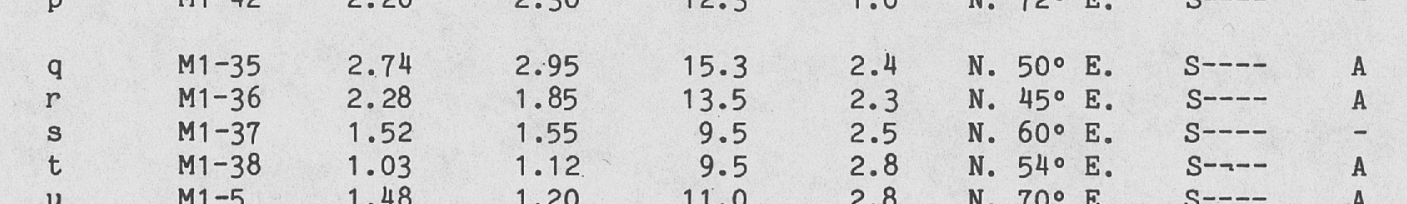

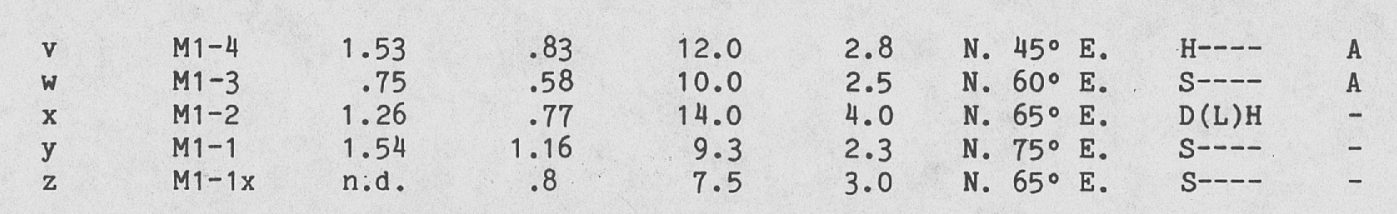
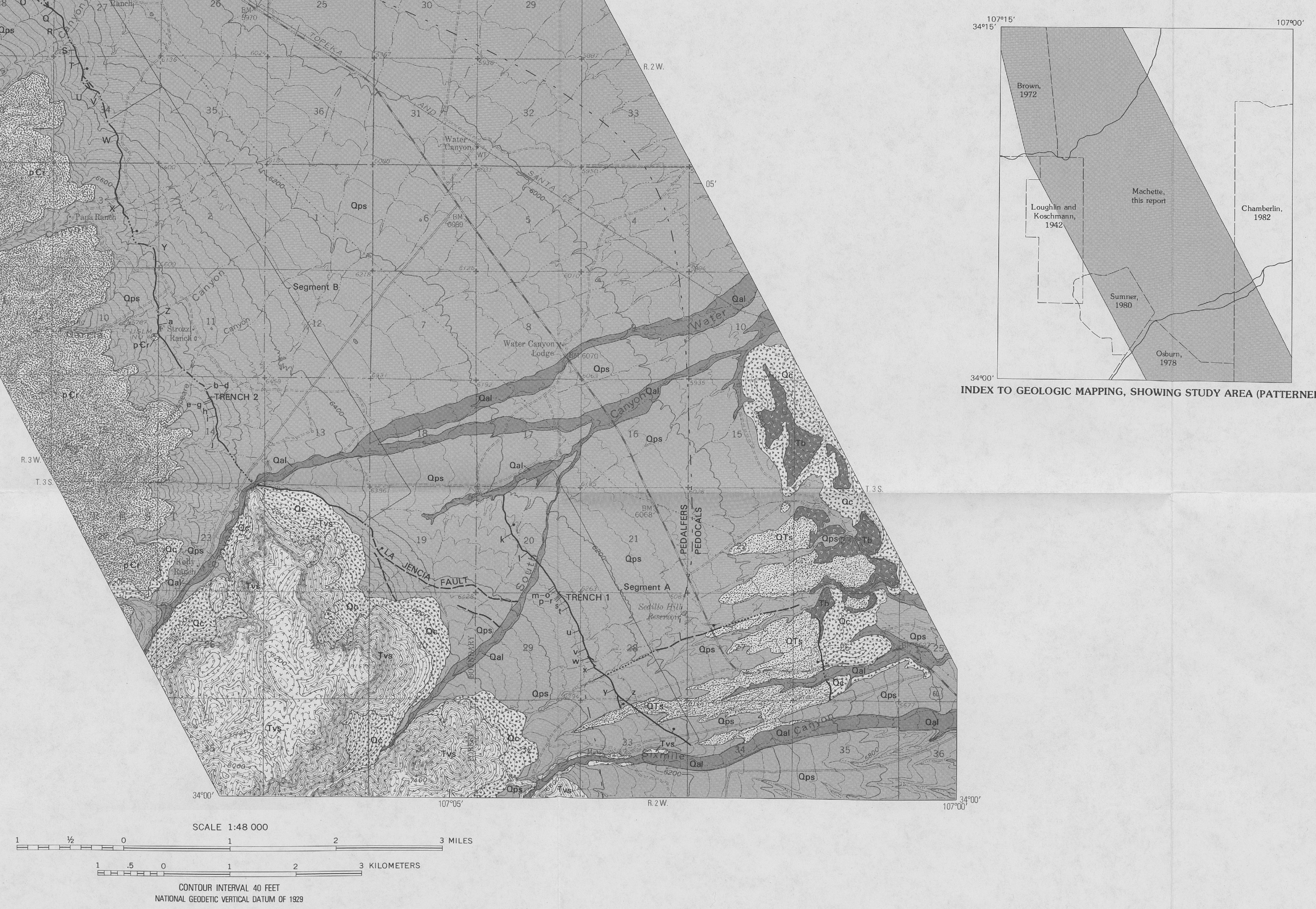

INDEX TO GEOLOGIC MAPPING, SHOWING STUDY AREA PATTERNED 
